\title{
COLETA SELETIVA DE RESÍDUOS SÓLIDOS URBANOS: ASPECTOS OPERACIONAIS E DA PARTICIPAÇÃO DA POPULAÇÃO
}

\section{JACQUELINE BRINGHENTI}

Tese de Doutorado apresentada ao Departamento de Saúde Ambiental da Faculdade de Saúde Pública da Universidade de São Paulo para obtenção do Grau de Doutor.

Área de Concentração: Saúde Ambiental

ORIENTADOR: PROF $^{\mathrm{a}}$ DR $^{\mathrm{a}}$ WANDA M. RISSO GÜNTHER

São Paulo 
Autorizo, exclusivamente para fins acadêmicos e científicos, a reprodução total ou parcial desta tese, por processos fotocopiadores.

Assinatura:

Data: 
Wagner e Anna Júlia, a vocês que dão um colorido especial à minha vida, dedico este trabalho. 


\section{AGRADECIMENTOS}

Ao pessoal do Departamento de Saúde Ambiental, em especial ao Serginho, à Profa. Hellena, ao Prof. José Luiz, ao Prof. Tadeu e ao Prof. Carlos Celso, por todo apoio e carinho;

À Profa. Wanda, minha orientadora e, acima de tudo, amiga, pelo apoio, paciência na correção dos meus escritos e compreensão, mesmo nos momentos mais difíceis;

Aos Professores Fernando Lefévre e Ana Lefévre, do Departamento de Práticas de Saúde Publica da FSP, cujos ensinamentos e co-orientação foram fundamentais para desenvolvimento da pesquisa qualitativa de campo;

À Prefeitura de Vitória, em especial à Secretária de Meio Ambiente Elizete Shering Siqueira ao ex-Secretário Jarbas Ribeiro de Assis Junior, ao Su6-Secretário de Serviços Carlos Roberto de Lima, às equipes do Centro de Documentação e Informação, do Departamento de Educação Ambiental, da Usina de lixo e do Departamento de Limpeza Pública, que permitiram e me deram apoio para que eu pudesse realizar este sonho;

Aos colegas da Prefeitura: Bebeto, Irene, Baptista, Rosi, Edmo, Jaeder, Ricardo, Luiz, Marcília, Rodrigo, Felipe, Ivani, Penélope, Marcinha, Vânia, Rose, Rita, Bia, Marilia, Joel, Adriano, Mileni, Fabrício, Flavinha, Karla, Yandi e Sandra. Valeu demais as sugestões, traduções, xeroxe palavras de apoio e, sobretudo, o auxilio no dia a dia da pesquisa. O apoio e o trabalho de vocês foi muito importante e está expresso nos resultados da Tese;

Aos colegas de trabalho do CEFETES, pelo apoio e incentivo;

Ao Grupo de Estudos e Ações em Resíduos Sófidos - GEARSOL da VFES, nas pessoas do Prof. Florindo, e ao pessoal do Mestrado, a Claudinha, Adriana, o Groberio, pela cessão das bibliografias, discussões e grande apoio;

À Profa Eliane Zandonade, do Departamento de Estatística da UFES que, através de ensinamentos e co-orientação, abriu os caminhos para o desenvolvimento da pesquisa de campo e, também, ao apoio da estatística Elaine ;

Aos amigos da ABES - Associação Brasileira de Engenharia Sanitária e Ambiental, em especial à Fernanda, ao Jair, a Roselaine, ao Noel, àIrene e à Maria Alice, pelo apoio nos momentos em que precisei me ausentar das atividades para me dedicar ao Doutorado;

À toda a minha família, especialmente aos meus pais, Elza e Roger, pela força, encorajamento e dedicação, em todas as etapas da pesquisa;

Ao Dr. Dilo Binda, pela confiança em meu potencial e incentivo;

À grande amiga Irene pela dedicação na revisão da tese e incentivo; e,

A todos que contribuíram para que esta pesquisa pudesse ter sido realizada. 


\section{RESUMO}

\section{BRINGHENTI, JR. Coleta Seletiva de Resíduos Sólidos Urbanos: Aspectos}

Operacionais e da Participação da População. São Paulo; 2004. [Tese de Doutorado - Faculdade de Saúde Pública da USP].

A criteriosa avaliação dos fatores envolvidos no planejamento e implantação da Coleta Seletiva de RSU contribui decisivamente para a adoção de diretrizes adequadas, em especial quanto a sua eficiência operacional e efetiva adesão da população alvo ao programa. Hipóteses. Hipótese 1: É possível representar os diversos aspectos operacionais envolvidos em Programas de Coleta Seletiva a partir de um grupo de indicadores. Hipótese 2: O tipo de participação social é fator de maior ou menor sucesso dos programas de coleta seletiva, havendo diferentes respostas da população em relação à participação que podem ser agrupadas em: grupo cativo, de participação eventual e que não participa. Objetivo. Avaliar aspectos operacionais e da participação da população em Programas de Coleta Seletiva de resíduos sólidos urbanos, tendo como estudo de caso o município de Vitória-ES, com a finalidade de: i) instituir grupo de indicadores de referência para o planejamento e a avaliação de desempenho de Programas de Coleta Seletiva; ii) identificar fatores de motivação da população quanto a participação em Programas de Coleta Seletiva; iii) propor diretrizes para subsidiar políticas publicas em Programas de Coleta Seletiva. Método. Estudo descritivo no qual, após etapa inicial preparatória, foram coletados dados de natureza qualitativa e quantitativa em campo, a partir de instrumentos de pesquisas adequados, que receberam tratamento estatístico e foram à base dos resultados, da avaliação, da análise de pontos críticos, da discussão e da conclusão. Em caráter complementar foi levantado o nível de informação da população direta e indiretamente envolvida com a implementação da coleta seletiva em Vitória. Resultados. A partir da revisão bibliográfica foram identificados 25 indicadores mais utilizados no país os quais, após terem sido validados por instrumento de pesquisa quantitativo associado a métodos estatísticos, foram reduzidos a 6 indicadores considerados como Grupo de Indicadores de Referência. Esse grupo contemplou aspectos operacionais de custo, de escala e de participação da população e foi aplicado à série histórica de dados do município de 
Vitória, propiciando a identificação dos pontos críticos do programa de coleta seletiva implantado e demonstrando sua viabilidade. Os principais fatores de motivação da população quanto à participação na coleta seletiva foram: o meio ambiente e a qualidade de vida, associado à melhoria da limpeza urbana. Conclusões e Recomendações. Os resultados obtidos poderão ter grande aplicação no gerenciamento, ampliação e melhoria de programas de coleta seletiva em todo país uma vez que a aplicação do grupo de indicadores instituído é relativamente simples e representa adequadamente os diversos aspectos operacionais envolvidos. A divisão da população alvo de programas de coleta seletiva em grupo cativo, de participação eventual e que não participa é adequada e proporciona análise mais simplificada e planejamento das ações de mobilização e divulgação. A participação da população na coleta seletiva é decorrência da organização e adequação da estrutura implantada para dar suporte ao programa e da existência de ações continuadas de divulgação, informação e mobilização. Recomenda-se que os responsáveis pela coleta seletiva criem rotinas de registro de informações e cadastro de dados sobre o seu desenvolvimento e que sejam periodicamente divulgados na forma de indicadores. Destacam-se a necessidade e a importância da criação de política pública para o setor.

Descritores: Resíduos Sólidos Urbanos, Gerenciamento de Resíduos Sólidos, Coleta Seletiva, Reciclagem, Indicadores Ambientais e Participação da População. 


\begin{abstract}
BRINGHENTI, JR. Coleta Seletiva de Resíduos Sólidos Urbanos: Aspectos Operacionais e da Participação da População. [Selective Collection of Urban Solid Wastes: Operational Aspects and Participation of Population]. São Paulo (BR); 2004. [Tese de Doutorado - Faculdade de Saúde Pública da Universidade de São Paulo].
\end{abstract}

The detailed evaluation of factors involved in the planning and implantation of Selective Collection is an important contributing factor in the decision to adopt adequate measures, specifically in regards to its operational efficiency and effective inclusion of the target population in the program. Hypothesis. Hypothesis 1: Many operational aspects of the Program of Selective Collection can be shown by a group of indicators. Hypothesis 2: The type of social participation is a better or worst factor of success in the programs of selective collection, having different population answers regarding the participation, which can be grouped in: those who does participate, those who occasionally participate and those who do not participate. Objective. To evaluate the general operation of the Programs of Selective Collection of Urban Waste, as well as regularity of participation of population, specifically targeting case studies from the municipality of Vitoria, ES, in order to: i) identify and utilize points of reference for the planning of evaluation and performance in the Programs of Selective Collect; ii) identify factors that motivate the population to participate the program; iii) to propose a plan to subside a public policy in Programs of Selective Collection. Methods. Detailed studies from which, after the initial preparatory phase, qualitative and quantitative data was obtained through use of proper means of research of a statistical nature were the basis for all results, evaluations, analysis of critical factors, discussions and conclusions. As a result, the comprehension level of the involved, directly or indirectly, in establishing the Program of Selective Collection in Vitoria has been increased. Results. A bibliographical revision has allowed us to identify the 25 most used indicators in the country, which after being validated with quantitative research instruments in conjunction with statistical methods, have been reduced to 6 indicators which are 
considered our Group of Reference Indicators. This group has considered the operational aspects of cost, scale and participation of population and has been applied to historical data of Vitoria, thereby allowing the identification of all critical aspects of the implemented program and demonstrating its viability. The most important factors for the involvement of the population with the program have also been identified: the environment and quality of life as they relate to an overall improvement in urban cleanness. Conclusions and Recommendations. The results obtained can be successfully applied to the management, expansion and improvement of selective collection programs across the country, as the process of applying the group of indicators is relatively simple and adequately represents the various operational aspects involved. The process of dividing the target population into three groups, those who does participate, those who occasionally participate and those who does not participate is suitable and enables more effective analysis and planning of projects with the objective of informing and mobilizing the population. The participation of population in selective collection is the result of an organized and adequately structured support system for the program and continuous efforts to educate, inform and mobilize. It is recommended that those responsible for the program of selective collection create a system of routinely registering data and progress reports, which should be regularly divulged in the form of indicators. It is necessary and important the creation of public policy for the sector.

Descriptors: Urban Solid Waste, Management of Solid Waste, Selective Collection, Recycling, Enviromental Indicators and Participation of the Population. 
1. INTRODUÇÃ̃O

2. REVISÃO DA LITERATURA

2.1 Contextualizando os Resíduos Sólidos

2.2 Padrão de Produção e Consumo

2.3 Gestão Integrada dos Resíduos Sólidos

2.4 Minimização de Resíduos Sólidos

2.5 Coleta Seletiva

2.6 Participação Social

2.7 Programas de Coleta Seletiva no Brasil

2.8 O uso de Indicadores no Planejamento e Gestão da Coleta Seletiva

3. FORMULAÇÃO DO PROBLEMA

4. OBJETIVOS

4.1 Objetivo Geral

4.2 Objetivos Específicos

5. METODOLOGIA

5.1 Objeto de Estudo

5.2 Levantamento de Dados

5.2.1 Instrumentos de Pesquisa

5.2.1.1 Pesquisa sobre Indicadores Operacionais

5.2.1.2 Pesquisa sobre a Participação Social

6. RESULTADOS E DISCUSSÃO

6.1 Experiências de Coleta Seletiva em Governos Municipais

\begin{tabular}{l|l|l} 
6.1.1 Coleta Seletiva em São Bernardo do Campo -SP & 68
\end{tabular}

\begin{tabular}{l|l} 
6.1.2 Coleta Seletiva em Porto Alegre - RS & 72
\end{tabular}

\begin{tabular}{l|l} 
6.1.3 Coleta Seletiva em Florianópolis - SC & 82
\end{tabular}

\begin{tabular}{l|l} 
6.1.4 Coleta Seletiva em Santo André - SP & 90
\end{tabular} 


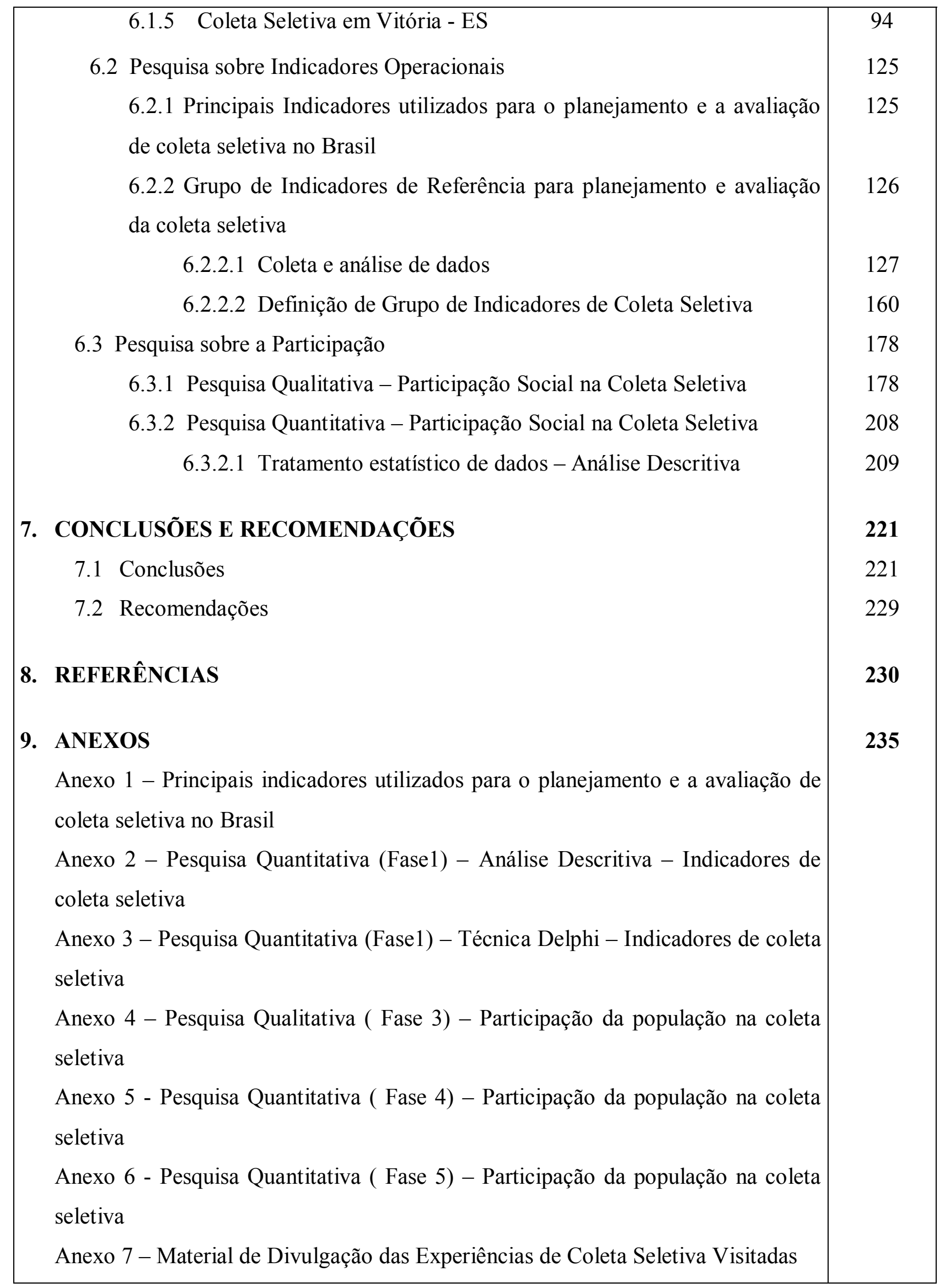





\section{LISTA DE FIGURAS}

\section{CAPÍTULO 2}

Figura 1 - Matriz objetivos da Prefeitura X objetivos da gestão de resíduos sólidos

Figura 2 - Matriz objetivos da gestão dos resíduos sólidos na prefeitura $\mathrm{X}$ fatores críticos de sucesso da coleta seletiva

Figura 3 - Matriz fatores críticos de sucesso da coleta seletiva X problemas da coleta seletiva

Figura 4 - Matriz fatores críticos de sucesso da coleta seletiva X necessidades de informação

\section{CAPÍTULO 5}

Figura 5 - Distribuição espacial das modalidades de coleta seletiva implantadas no município de Vitória, segundo classe social. 2002

\section{CAPÍTULO 6}

Figura 6 - Coleta de materiais recicláveis armazenados em ECOPONTOS com recipientes de 2500 1, São Bernardo do Campo, 2001

Figura 7 - Coleta de materiais recicláveis armazenados em ECOPONTOS com recipientes de 2500 1, São Bernardo do Campo, 2001

Figura 8 - Operação da Coleta Seletiva porta a porta, Porto Alegre, 2002

Figura 9 - Operação da coleta seletiva porta a porta, detalhe do EPI utilizado, Porto Alegre, 2002

Figura 10 - Operação de descarga do caminhão da coleta seletiva porta a porta, Porto Alegre, 2002

Figura 11 - Unidade de Triagem e Reciclagem de Vila Cavalhada, Porto Alegre, 2002

Figura 12 - Unidade de Triagem e Reciclagem de Vila Cavalhada, Porto Alegre, 2002

Figura 13 - Unidade de Triagem de Vila Cavalhada, Porto Alegre, 2002

Figura 14 - Vista de PEV utilizado em órgãos públicos e condomínios, Porto 
Alegre, 2002

Figura 15 - Vista de PEV utilizado em parques, Porto Alegre, 2002.

Figura 16 - Ação de catadores junto a operação da coleta seletiva porta a porta, Porto Alegre, 2002.

Figura 17 - Ação de família de catadores junto a operação da coleta seletiva porta a porta, Porto Alegre, 2002.

Figura 18 - Vista do veículo baú utilizado para Coleta Seletiva, Florianópolis, 2002.

Figura 19 - Operação da Coleta Seletiva, Florianópolis, 2002.

Figura 20 - Operação da Coleta Seletiva, Florianópolis, 2002.

Figura 21 - Vista do depósito de recicláveis dos papeleiros, Florianópolis, 2002.

Figura 22 - Carrinho para coleta de recicláveis dos papeleiros, Florianópolis, 2002.

Figura 23 - Operação da coleta seletiva porta a porta, Santo André, 2002.

Figura 24 - Vista do Centro de Educação Ambiental, Santo André, 2002.

Figura 25 - Equipamento utilizado em Posto de Entrega Voluntária no período de 1998 a 2002, Vitória, 2002.

Figura 26 - Operação da Coleta seletiva por PEV's de Vitória - ES

Figura 27 - Adesivo afixado nas sacolas com resíduos rejeitados para coleta seletiva porta a porta, Vitória, 2003.

Figura 28 - Resíduos rejeitados pela coleta seletiva porta a porta, Vitória, 2003.

Figura 29 - Resíduos rejeitados pela coleta seletiva porta a porta, Vitória, 2003.

Figura 30 - Lançamento da coleta seletiva por PEV's em Vitória, 2002.

Figura 31 - Operação da coleta seletiva porta a porta, Vitória, 2003.

Figura 32 - Iniciativa de condomínio para se adequar a coleta seletiva porta a porta, Vitória, 2003.

Figura 33 - Vista de caminhão gaiola de sucateiro atuando em região de coleta seletiva porta a porta, Vitória, 2003.

Figura 34 - Vista de unidade de triagem operada por organização de trabalhadores autônomos da reciclagem, Florianópolis, 2002. 


\section{LISTA DE QUADROS}

\section{CAPÍTULO 2}

Quadro 1 - Marcos da gestão urbana e ambiental do Projeto Geo Cidades, 2002

Quadro 2 - Princípios de sustentabilidade aplicados à gestão dos RSU

Quadro 3 - Aspectos positivos e negativos das modalidades de coleta seletiva.

Quadro 4 - Relações entre o Homem e as quatro dimensões de mundo

\section{CAPÍTULO 5}

Quadro 5 - Etapas metodológicas de desenvolvimento da pesquisa. Vitória, 2003

Quadro 6 - Bairros sorteados para aplicação da primeira etapa da pesquisa qualitativa, segundo classe sócio-econômica e estratificação por modalidade da coleta seletiva.

Quadro 7 - Bairros selecionados para a segunda etapa da pesquisa qualitativa, segundo classe sócio-econômica e estratificação por modalidade de coleta seletiva, em Vitória.

Quadro 8 - Setores selecionados para a Fase 5 da pesquisa, segundo sua origem.

\section{CAPÍTULO 6}

Quadro 9 - Características de Programas de Coleta Seletiva Porta a Porta

Quadro 10 - Indicadores avaliados, como muito importante, na Análise Descritiva e na Técnica Delphi, relacionados aos fatores identificados na Análise Multivariada Fatorial. Alegre, 2002

Quadro 11 - Indicadores de Referência da Coleta Seletiva

Quadro 12 - Itens de materiais recicláveis comercializados pela UTCV.

Quadro 13 - Principais dificuldades para implantação e operação da coleta seletiva em municípios, segundo experiências levantadas nos municípios de São Bernardo do Campo, Porto Alegre, Florianópolis, Santo André e Vitória, aplicadas ao estudo de caso do município de Vitória.

Quadro 14 - Idéias Centrais e Ancoragem síntese referentes à pergunta P1

Quadro 15 - Idéias Centrais e Ancoragem síntese referentes à pergunta P2/2.1 
Quadro 16 - Idéias Centrais e Ancoragem síntese referentes à pergunta P2/2.2 193

Quadro 17 - Idéias Centrais e Ancoragem síntese referentes à pergunta P3 195

Quadro 18 - Idéias Centrais e Ancoragem síntese referentes à pergunta P4 204

Quadro 19 - Amostra da pesquisa quantitativa sobre a participação na coleta seletiva realizada na prefeitura de Vitória. Vitória, 2002. 209

Quadro 20 - Características positivas e negativas do novo modelo de PEV instalado na cidade em relação ao anterior, segundo respostas dos questionários. 215

Quadro 21 - Citações sobre o interesse em ter informações adicionais sobre a coleta seletiva, segundo respostas dos questionários. 


\section{LISTA DE TABELAS}

\section{CAPÍTULO 6}

Tabela 1 - Resultados da avaliação dos indicadores, feita pelos entrevistados, segundo estatística descritiva.

Tabela 2 - Descrição dos resultados da avaliação dos indicadores feita pelos entrevistados, segundo estatística descritiva por grau de importância.

Tabela 3 - Agrupamento dos indicadores de coleta seletiva em 8 fatores, segundo Análise Multivariada Fatorial.

Tabela 4 - Variância total explicada por fator, segundo Análise Multivariada Fatorial

Tabela 5 - Resultados das avaliações dos indicadores, feitas pelos entrevistados agrupados, para o critério de avaliação VALIDADE, segundo grau de importância atribuída

Tabela 6 - Resultados das avaliações dos indicadores feita pelos entrevistados agrupados para o critério de avaliação CONFIABILIDADE, segundo grau de importância atribuída

Tabela 7 - Resultados das avaliações dos indicadores feitas pelos entrevistados agrupados para o critério de avaliação REPRESENTATIVIDADE, segundo grau de importância atribuída

Tabela 8 - Resultados das avaliações dos indicadores feitas pelos entrevistados agrupados para o critério de avaliação OPORTUNIDADE, segundo grau de importância atribuída

Tabela 9 - Média geral dos resultados da avaliação dos indicadores feita pelo: entrevistados, agrupados para diversos critérios de avaliação utilizados, segund, grau de importância atribuída.

Tabela 10 - Há quanto tempo você participa da coleta seletiva?

Tabela 11 - Fontes de informação sobre coleta seletiva de lixo

Tabela 12 - Outros meios de obtenção de informação sobre coleta seletiva.

Tabela 13 - Tempo de armazenamento do resíduo reciclável nas casa ou local de trabalho dos entrevistados 



\section{LISTA DE GRÁFICOS}

\section{CAPÍTULO 6}

Gráfico 1 - Distribuição percentual de PEVs, segundo região administrativa do município de Vitória, no período de setembro/2002 a maio/2003. Vitória.

Gráfico 2 - Distribuição percentual dos $10 \mathrm{PEVs}$ de melhor desempenho operacional, segundo ponto de referencia de sua localizacão, no período de setembro/2002 a maio/2003. Vitória.

Gráfico 3 - Distribuição percentual dos 10 PEVs de pior desempenho operacional, segundo ponto de referencia de sua localizacão, no período de setembro/2002 a maio/2003. Vitória.

Gráfico 4 - Distribuição percentual das ocorrências de vandalismo, segundo ponto de referência de localização, no período de setembro/2002 a maio/2003. Vitória.

Gráfico 5 - Distribuição percentual dos tipos de vandalismo, no período de setembro/2002 a maio/2003. Vitória.

Gráfico 6 - Evolução de demandas do serviço LIG-LIXO para coleta seletiva porta a porta, no período de novembro de 2002 a maio de 2003.

Gráfico 7 - Evolução da quantidade de resíduo seco coletado, na coleta seletiva porta a porta, no período de novembro/ 2002 a maio/ 2003. Vitória, 2003.

Gráfico 8 - Evolução do percentual de rejeito no lixo seco coletado, pela coleta seletiva porta a porta, no período de novembro/ 2002 a maio/2003. Vitória, 2003

Gráfico 9 - Box Plot de todos os indicadores propostos.

Gráfico 10 - Erro Bar de todos os indicadores propostos.

Gráfico 11 - Box Plot dos indicadores de média importância

Gráfico 12 - Box Plot dos indicadores de muita importância

Gráfico 13 - Erro Bar dos indicadores de média importância.

Gráfico 14 - Erro Bar dos indicadores de muita importância

Gráfico 15 - Box Plot dos indicadores de média importância para o critério de avaliação VALIDADE

Gráfico 16 - Box Plot dos indicadores de muita importância para o critério de avaliação VALIDADE. 
Gráfico 17 - Erro Bar dos indicadores de média importância para o critério de avaliação VALIDADE.

Gráfico 18 - Erro Bar dos indicadores de muita importância para o critério de avaliação VALIDADE.

Gráfico 19 - Box Plot dos indicadores de média importância para o critério de avaliação CONFIABILIDADE.

Gráfico 20 - Box Plot dos indicadores de muita importância para o critério de avaliação CONFIABILIDADE.

Gráfico 21 - Erro Bar dos indicadores de média importância para o critério de avaliação CONFIABILIDADE.

Gráfico 22 - Erro Bar dos indicadores de muita importância para o critério de avaliação CONFIABILIDADE.

Gráfico 23 - Box Plot dos indicadores de média importância para o critério de avaliação REPRESENTATIVIDADE.

Gráfico 24 - Box Plot dos indicadores de muita importância para o critério de avaliação REPRESENTATIVIDADE.

Gráfico 25 - Erro Bar dos indicadores de média importância para o critério de avaliação REPRESENTATIVIDADE.

Gráfico 26 - Erro Bar dos indicadores de muita importância para o critério de avaliação REPRESENTATIVIDADE.

Gráfico 27 - Box Plot dos indicadores de média importância para o critério de avaliação OPORTUNIDADE.

Gráfico 28 - Box Plot dos indicadores de muita importância para o critério de avaliação OPORTUNIDADE.

Gráfico 29 - Erro Bar dos indicadores de média importância para o critério de avaliação OPORTUNIDADE.

Gráfico 30 - Erro Bar dos indicadores de muita importância para o critério de avaliação OPORTUNIDADE.

Gráfico 31 - Evolução da cobertura de atendimento (hab), segundo modalidade de coleta seletiva, período de janeiro/ 2003 a maio/ 2003. Vitória, 2003. 
Gráfico 32 - Evolução do IRMR, segundo modalidade de coleta seletiva existentes no período de janeiro/ 2001 a maio/ 2003. Vitória, 2003.

Gráfico 33 - Evolução da quantidade de materiais recicláveis (MR) coletados (t), segundo modalidade de coleta seletiva, no período de janeiro/ 2001 a maio/ 2003. Vitória, 2003.

Gráfico 34 - Evolução do custo de triagem $(\mathrm{R} \$ / \mathrm{t})$, segundo modalidade de coleta seletiva, período de janeiro/ 2001 a maio/ 2003. Vitória, 2003.

Gráfico 35 - Evolução do custo do programa (R\$/t), segundo modalidades de coleta seletiva, período de janeiro/ 2001 a maio/ 2003. Vitória, 2003.

Gráfico 36 - Fontes de informação sobre coleta seletiva de lixo.

Gráfico 37 - Motivação para participar da coleta seletiva. 


\section{LISTA DE SIGLAS}

ABNT - Associação Brasileira de Normas Técnicas

ARESP - Associação de Recicladores Esperança

ASCAMARE - Associação de Catadores de Materiais Recicláveis de Vitória

CEMPRE - Compromisso Empresarial para Reciclagem

CETESB - Companhia de Tecnologia de Saneamento Ambiental

CETRE - Centro de Transferência de Resíduos Sólidos

CIRS - Centro de Informação sobre Resíduos Sólidos

COMCAP - Companhia de Melhoramentos da Capital

DMLU - Departamento Municipal de Limpeza Urbana.

DSC - Discurso do Sujeito Coletivo

EPI - Equipamento de Proteção Individual

IBAM - Instituto Brasileiro de Administração Municipal

IBGE - Instituto Brasileiro de Geografia e Estatística

IRMR - Índice de Recuperação de Materiais para Reciclagem

ISER - Instituto de Estudos da Religião

MMA - Ministério do Meio Ambiente

PEV's - Postos de Entrega Voluntária

PNUMA - Programa das Nações Unidas para o Meio Ambiente

PUC-PR/ISAM - Pontifícia Universidade Católica do Paraná/ Instituto de Saneamento Ambiental

RSU - resíduos sólidos urbanos

SEDU - Secretaria de Desenvolvimento Urbano (governo federal)

SEMASA - Serviço Municipal de Saneamento Ambiental de Santo André

SEMMAM - Secretaria Municipal de Meio Ambiente

SEMURB - Secretaria Municipal de Serviços

SLU - Sistema de Limpeza Urbana

s.m. - salários mínimos

SNIS - Sistema Nacional de Informações em Saneamento

SPSS - Statistical Package for the Social Sciences

UTCV - Unidade de triagem e compostagem de Vitória 


\section{INTRODUÇÃO}

No mundo moderno, a produção de resíduos sólidos vem aumentando numa escala considerável, causando vários problemas ao ambiente e à saúde pública. Todas as etapas do gerenciamento dos resíduos sólidos, que englobam desde a sua geração até sua disposição final, exigem soluções conjuntas entre os governantes e a sociedade, haja visto que o volume dos resíduos cresce em proporções geométricas, enquanto a solução para a questão aumenta em escala aritmética.

Devido à destinação dos resíduos sólidos representar um risco potencial à saúde pública e ao ambiente, é necessário que as medidas tomadas para seu gerenciamento sejam muito bem estudadas e selecionadas, utilizando-se para isso os pressupostos da engenharia sanitária associados aos conteúdos da administração, da economia e demais áreas afins, adotando-se técnicas mais adequadas de manejo e evitando custos elevados que inviabilizem a sua execução.

Atualmente, a maioria dos centros urbanos encontra problemas para dispor o lixo no solo. A estratégia de minimização de resíduos, onde o foco seria evitar ao máximo o lixo a ser disposto no solo, a partir dos princípios de redução, reutilização e reciclagem, é uma medida adequada para se introduzir nesse contexto, sensibilizando o consumidor para que compre produtos com embalagens retornáveis, reutilizáveis, recicláveis; que evite o desperdício de matérias primas, insumos em geral como também outros bens de consumo; e que encaminhe seus resíduos para a recuperação. A coleta seletiva é um instrumento de gestão ambiental que deve ser implementado visando à recuperação de material reciclável para fins de reciclagem.

Apesar da mídia explorar freqüentemente o tema, no Brasil, a maior parte das iniciativas e ações de coleta seletiva são informais. No país tem-se apenas 3,5\% dos 5.561 municípios operando programas de coleta seletiva, o que corresponde a 192 experiências implantadas e em funcionamento, conforme demonstra recente pesquisa sobre o tema, desenvolvida pelo Compromisso Empresarial para Reciclagem (CEMPRE 2002).

Recente pesquisa sobre Sistemas de Coleta Seletiva no país promovida pela Secretaria de Desenvolvimento Urbano - SEDU (2002), órgão do governo federal, enfatiza que 
a redução na geração de resíduos está ganhando, cada vez mais, atenção como uma importante forma de manejo de resíduos sólidos.

Os programas de coleta seletiva, em geral, buscam transformar o comportamento da sociedade, em relação ao lixo que gera, apresentando-se como uma das alternativas para que as pessoas, no seu cotidiano, possam contribuir com a preservação do ambiente e redução dos impactos sanitários e ambientais. Entretanto, na prática, existe muita desinformação sobre o tema embora suscite interesses localizados.

Sobre tal ponto GRIMBERG e BLAUTH (1998) afirmam que:

"Existe uma certa confusão em torno do conceito de coleta seletiva. É comum as pessoas entenderem a coleta como sinônimo de separação de materiais descartados ou, ainda, como reciclagem. Há quem diga, por exemplo, que "faz coleta seletiva" em casa, mas queixa-se de que seu bairro ou sua cidade "não tem reciclagem". Outros garantem que "reciclam" seu lixo mas que, infelizmente, "o lixeiro mistura tudo". " (p.17).

Na prática, existe ainda, grande carência de informações sobre coleta seletiva que tem levado técnicos e pesquisadores do setor a apontar a necessidade de se buscar padronização na apresentação de experiências, fundamental para comparações e análises, que possa subsidiar à implantação de novos programas, o planejamento e à execução de políticas e ações mais adequadas para o setor.

Neste contexto, reveste-se de importância o estabelecimento de indicadores para os programas de coleta seletiva, que sejam de fácil entendimento e aplicação prática aos diversos portes e peculiaridades dos municípios brasileiros.

Uma vez que Reduzir, Reutilizar e Reciclar os resíduos sólidos urbanos constitui-se, atualmente, na principal estratégia para a redução do passivo ambiental decorrente da disposição inadequada desses resíduos, é de grande importância o correto entendimento de métodos e técnicas que envolvam a coleta seletiva de resíduos, como também de componentes técnicas, econômicas e sociais envolvidas no processo. 


\section{REVISÃO DA LITERATURA}

\subsection{Contextualizando os Resíduos sólidos}

Os resíduos sólidos, de acordo com a definição da Associação Brasileira de Normas Técnicas - ABNT (2004), são resíduos que resultam de atividades de origem industrial, doméstica, hospitalar, comercial, agrícola, de serviços e de varrição, podendo se apresentar nos estados físicos sólido e semi-sólido. Estão incluídos nesta definição os lodos provenientes de sistemas de tratamento de água, aqueles gerados em equipamentos e instalações de controle de poluição, bem como determinados líquidos cujas particularidades tornem inviável o seu lançamento na rede pública de esgotos ou corpos de água, ou exijam para isso soluções, técnica e economicamente, inviáveis em face à melhor tecnologia disponível.

Os resíduos sólidos podem ser classificados, conforme a sua origem, em: resíduos domiciliares, de serviços de saúde, comerciais, industriais, de varrição, radioativos, de portos e aeroportos, entre outros. Como resíduos sólidos urbanos ou lixo urbano pode-se entender os resíduos coletados pelo serviço de coleta regular da municipalidade, incluindo-se o resíduo domiciliar, de varrição e comercial, os quais podem ser encaminhados para disposição final em aterro sanitário.

A coleta regular de resíduos sólidos urbanos faz parte dos serviços de limpeza urbana, sendo atribuição dos municípios.

MONTEIRO e col. (2001) consideram como partes integrantes do sistema de limpeza urbana de um município as etapas de geração, acondicionamento, coleta, transporte, transferência, tratamento e disposição final dos resíduos sólidos, além da limpeza de logradouros públicos.

Os mesmos autores ressaltam que o tema da limpeza urbana vem se destacando entre as crescentes demandas da sociedade brasileira e das comunidades locais, seja pelos aspectos ligados à veiculação de doenças e, portanto, à saúde pública; seja pela contaminação de cursos d'água e lençóis freáticos, na abordagem ambiental; seja pelas questões sociais ligadas aos catadores - em especial às crianças que vivem nos lixões - ou ainda pelas pressões advindas das atividades turísticas. Estando em curso o 
processo de mobilização de vários setores governamentais e da sociedade civil para enfrentar o problema, por muito tempo relegado a segundo plano.

AZEVEDO e col. (2001) realizaram estudo para avaliação do potencial de risco à saúde humana decorrente da disposição inadequada dos resíduos sólidos, constataram o quanto a relação resíduo sólido versus doença é complexa e avaliaram o risco ao qual a população exposta está sujeita quando a alternativa de disposição adotada é o lixão ou aterro controlado. Os autores concluem que: os resíduos sólidos devem ser considerados como um importante componente do perfil epidemiológico de uma comunidade e, que as práticas de gestão destes resíduos devem abordar estes aspectos, a fim de melhorar não só a qualidade ambiental, como também as condições de saúde da população.

Como o gerenciamento dos resíduos sólidos urbanos é de responsabilidade do município, torna-se importante que o poder público local desenvolva ações que oriente os cidadãos a tomarem medidas que levem à minimização de geração de resíduos, bem como participem de programas de coleta seletiva, visando buscar a cooperação da população para equacionar a questão.

\subsection{Padrão de Produção e Consumo}

Se quisermos ter menos lixo, precisamos rever nosso paradigma de felicidade humana. Ter menos lixo significa ter... mais qualidade, menos quantidade mais cultura, menos símbolos de status mais esporte, menos material esportivo mais tempo para as crianças, menos dinheiro trocado mais animação, menos tecnologia de diversão mais carinho, menos presente......

(GRIMBERG e BLAUTH 1998, p.7). 
Segundo PORTILHO (2004), atualmente verifica-se a contribuição desigual de pessoas com diferentes estilos de vida e práticas de consumo, com relação aos problemas ambientais globais.

Em nossa sociedade capitalista, praticamente, $80 \%$ dos recursos naturais são consumidos por $20 \%$ da população e o sucesso é medido pela quantidade de coisas que se pode ter. Como conseqüência, o cidadão está cada vez mais despolitizado, reduzido à condição de consumidor. A autora considera que a crise ambiental é uma construção social e que, ao longo do tempo, houve transições no discurso utilizado para problematizar a questão, conforme sistematizado a seguir:

- até a década de 70 - os problemas ambientais eram decorrentes do crescimento populacional;

- a partir da década de 70 - os problemas ambientais eram decorrentes do impacto da produção;

- a partir da década de 90 - os problemas ambientais são decorrentes do impacto do consumo.

Alguns autores afirmam que a matriz desse problema está no modelo de desenvolvimento adotado em quase todo o mundo ocidental, o qual exibe um padrão de consumo exagerado que produz resíduos numa quantidade tal que a natureza já não mais consegue absorver ou processar.

Segundo COSTA e SILVA e col. (2001), a crise enfrentada afeta a todos os sistemas que regem a sociedade atual, inclusive a própria ciência. A falência dos sistemas políticos, de valores, educacionais e econômicos existentes nos dias atuais provocam rupturas ecológicas, distanciamento do ser humano da natureza e crise de paradigma e ambiental.

Diante de tais fatos, constata-se a necessidade de se reavaliar os padrões de consumo da sociedade, assim como a exigência de que os responsáveis pelas políticas públicas passem a buscar soluções responsáveis e realistas.

O estabelecimento de um gerenciamento racional e integrado das questões inerentes à geração e disposição final de resíduos sólidos urbanos pode render, às comunidades, maior sustentabilidade ambiental e eqüidade social. 
A Agenda 21, documento assinado por 170 países, inclusive o Brasil, resultante da Conferência Mundial de Meio Ambiente e Desenvolvimento - CNUMAD de 1992 adota uma série de princípios que visam estabelecer entre os países uma nova parceria global e igualitária com a finalidade de proteger a integridade do ambiente e promover o desenvolvimento sustentável.

Na Agenda 21 está contemplada a questão do consumo sustentável. O documento estabelece que os Estados devem reduzir e eliminar mecanismos de produção e consumo insustentáveis e promover políticas públicas adequadas, a fim de alcançar o desenvolvimento sustentável e a melhoria da qualidade de vida das populações (ISER 1996).

Os padrões e níveis de consumo das sociedades capitalistas atuais são socialmente injustos, moralmente indefensáveis e ambientalmente insustentáveis e a adoção dos princípios do Consumo Sustentável, como parte de um estilo de vida sustentável numa sociedade sustentável, seria uma estratégia importante para a formação de sujeitos sociais ativos e de retorno do cidadão (PORTILHO 2004).

O Projeto GEO CIDADES - CIDADES SUSTENTÁVEIS (MMA 2002), uma iniciativa do Programa das Nações Unidas para o Meio ambiente - PNUMA, com o apoio técnico e financeiro do Ministério do Meio Ambiente - MMA do Brasil propõe um grande avanço neste sentido. O projeto das Cidades Sustentáveis visa, principalmente:

- propiciar a avaliação do estado do meio ambiente nos assentamentos urbanos, a partir da consideração dos determinantes específicos produzidos pelo processo de urbanização sobre os recursos naturais e os ecossistemas das cidades e seu entorno;

- auxiliar os processos de tomada de decisão e de gestão ambiental urbana;

- subsidiar a discussão e avaliação de temas estratégicos à melhoria da qualidade ambiental nas cidades, como, por exemplo, a democratização das políticas públicas, a descentralização da gestão ambiental nas esferas do Poder Público e dos serviços, e os avanços na consecução de objetivos voltados ao desenvolvimento sustentável em âmbito nacional e local. 
A construção de uma cidade saudável implica no desenvolvimento de iniciativas que contemplem os aspectos relacionados à cidade e à sua comunidade, objetivando a melhoria da qualidade de vida da população, sendo parte de um processo que confere aos cidadãos os meios para assegurar maior controle e melhoria de sua própria saúde. No Quadro 1, são apresentados os marcos da gestão urbana e ambiental propostos pelo Projeto Geo Cidades, também para o Brasil.

Quadro 1 - Marcos da gestão urbana e ambiental do Projeto Geo Cidades, 2002

\section{Mudança de escala}

- incentivar o surgimento de cidades ou de assentamentos urbanos menores, dentro da grande cidade;

- dar preferência aos pequenos projetos, de menor custo e de menor impacto ambiental; e,

- focar a ação local.

Incorporação da dimensão ambiental nas políticas setoriais urbanas

(habitação, saneamento, uso do solo, entre outras)

. observar os critérios ambientais para preservar recursos estratégicos (água, solo, cobertura vegetal) e proteger a saúde humana.

\section{Integração das ações de gestão}

- reduzir custos e ampliar os impactos positivos para criar sinergias.

\section{Necessidade de planejamento estratégico}

. restringir o crescimento não-planejado ou desnecessário.

\section{Descentralização das ações administrativas e dos recursos}

- contemplar prioridades locais e combater a homogeneização dos padrões de gestão.

\section{Incentivo à inovação}

. incentivar o surgimento de soluções criativas; abertura à experimentação (novos materiais, novas tecnologias e novas formas organizacionais). 
Quadro 1 - Marcos da gestão urbana e ambiental do Projeto Geo Cidades, 2002. cont.

\section{Inclusão de custos ambientais e sociais no orçamento}

. prever os custos ambientais e sociais nas obras de infra-estrutura;. induzir novos hábitos de moradia, transporte e consumo nas cidades;

. incentivar o uso de bicicleta e de transportes não-poluentes;

. incentivar hortas comunitárias, jardins e arborização com árvores frutíferas; e,

. criar edificações, para uso comercial ou de moradia, que evitem o uso intensivo de energia, utilizando materiais reciclados.

\section{Fortalecimento da sociedade civil e dos canais de participação}

. incentivar e dar suporte à ação comunitária.

Fonte: MMA (2002)

Segundo LIMA (2002), a reversão do atual padrão de desenvolvimento, em direção à sustentabilidade ambiental, tem, no manejo adequado dos resíduos sólidos, um de seus maiores desafios, sendo que a adoção das práticas de gerenciamento integrado pelas municipalidades poderia ser a base do processo de enfrentamento do problema.

\subsection{Gestão Integrada dos Resíduos Sólidos}

No Brasil, cada vez mais vem se difundindo a importância da Gestão Integrada dos Resíduos Sólidos, entretanto a sua aplicação na prática ainda é restrita e a maioria das cidades trata a questão de forma isolada.

Manuais de referência sobre o tema editados no país definem a gestão integrada dos resíduos sólidos como:

o conjunto articulado de ações normativas, operacionais, financeiras $e$ de planejamento que uma administração municipal desenvolve, baseado em critérios sanitários, ambientais e econômicos para coletar, tratar e dispor o lixo da sua cidade (IPT/CEMPRE 1995, p. 3). 
O envolvimento de diferentes órgãos da administração pública e da sociedade civil, com o propósito de realizar a limpeza urbana, a coleta, o tratamento e a disposição final do lixo, elevando assim a qualidade de vida da população e promovendo o asseio da cidade, levando em consideração as características das fontes de produção, o volume e os tipos de resíduos - para a eles ser dado tratamento diferenciado e disposição final técnica e ambientalmente corretas -, as características sociais, culturais e econômicas dos cidadãos e as peculiaridades demográficas, climáticas e urbanísticas locais. (MONTEIRO e col. 2001, p. 8).

Segundo Schall (1992), apud MILANEZ e TEIXEIRA (2001, p.2), a visão moderna da gestão dos resíduos sólidos urbanos consiste no abandono do paradigma da disposição de resíduos, onde os mesmos são vistos como uma massa uniforme, que deve ser coletada, compactada e enterrada ou queimada, e na adoção de uma visão de que o resíduos sólidos é compostos a partir de diferentes materiais que, dependendo de suas características físicas, químicas e biológicas e de seu valor econômico, devem ser manejados mediante diferentes processos.

De acordo com o autor, o conceito de gestão integrada dos resíduos sólidos originouse de uma das possíveis traduções do termo solid waste management, que se refere a um conjunto de procedimentos para manejar o fluxo de resíduos sólidos municipais, causando o menor impacto possível sobre a saúde humana e ambiental. Como estratégias para o solid waste management, são citadas a redução na fonte (incluindo reúso), reciclagem de materiais (incluindo compostagem), combustão (com recuperação de energia) e disposição final. Sendo que o conceito americano considera a etapa anterior, a geração, atribuindo a incorporação dessa etapa como a principal distinção entre as formas de gerir os resíduos sólidos urbanos entre as visões tradicional e moderna.

LIMA (2002) sugere que a base da mudança do gerenciamento isolado para o integrado de resíduos sólidos deverá ser pautada por uma hierarquia de objetivos focada em quatro áreas programáticas: 
- minimização da geração de resíduos;

- maximização do reúso e da reciclagem;

- promoção do tratamento e da disposição final dos resíduos sólidos de forma ambientalmente segura;

- maximização da cobertura de serviços de limpeza urbana.

A combinação dessas ações deverá ser feita, no âmbito de cada município, para encontrar seu próprio modelo de gerenciamento integrado, de acordo com as condições territoriais, sócio-econômicas locais e a composição e quantidade de resíduos sólidos gerados.

A Gestão Integrada dos Resíduos Sólidos apresenta forte relação com os princípios de sustentabilidade ambiental, como pode ser notado no capítulo 21 da Agenda 21 Global (CNUMAD 1997). Esse documento estabelece que o manejo de resíduos, ambientalmente saudável, deve ir além da simples disposição ou aproveitamento por métodos seguros dos resíduos gerados. Deve-se buscar discutir a causa fundamental do problema, procurando mudar padrões não sustentáveis de produção e consumo. Isto implica na utilização do conceito de manejo integrado do ciclo vital, o qual apresenta oportunidade única de conciliar o desenvolvimento e a proteção do meio ambiente.

Partindo-se da premissa que a adoção e divulgação dos princípios da sustentabilidade, em programas de saneamento ambiental, leva as pessoas envolvidas a vislumbrar o resultado das mudanças propostas, além de orientar suas ações e colaborar na orientação dos legisladores e tomadores de decisão quanto aos objetivos das políticas públicas elaboradas, MILANEZ e TEIXEIRA (2001) propuseram um grupo de princípios de sustentabilidade específicos para a gestão dos RSU, conforme apresentado no Quadro 2. 
Quadro 2 - Princípios de sustentabilidade aplicados à gestão dos RSU.

- Universalização dos serviços. Todas as pessoas devem ser atendidas pelo sistema público de gestão de RSU, sendo dada atenção especial às comunidades economicamente carentes, as quais se apresentam mais suscetíveis aos impactos negativos decorrentes.

\section{. Integração dos aspectos econômicos, ambientais/ecológicos e sociais na gestão dos}

RSU. A gestão sustentável dos RSU possue dimensões econômicas, ambientais/ecológicas e sociais. Essas dimensões devem ser consideradas tanto no momento do planejamento, quanto na tomada de decisões, intervenções ou controle do sistema.

- Cooperação e consórcio. Na busca de soluções para os problemas dos RSU, as administrações públicas devem procurar agir em cooperação, seja entre si (por exemplo, consórcios intermunicipais), seja com outros setores da sociedade, minimizando custos operacionais e impactos negativos.

- Autonomia municipal sobre a gestão dos RSU. De acordo com o art. 30 da Constituição Federal Brasileira de 1988, as atividades de interesse local são de competência dos municípios. Assim os governos locais possuem autonomia para decidir sobre a recepção, ou não, dos RSU oriundos de outras localidades, bem como para o envio de seus resíduos para outros locais, desde que legalmente autorizado, para tratamento e/ou disposição final, devendo arcar com os custos ambientais, econômicos e políticos de tais decisões. No caso de resíduos especiais deve ser observada a legislação estadual e federal pertinente.

- Adequação das tecnologias à realidade local. Soluções tecnológicas, tanto do ponto de vista de equipamentos, quanto de processos e sistemas, devem ser implantadas, mas não somente baseadas em experiências de terceiros. As respostas para os problemas, mesmo que inspiradas em situações semelhantes devem ser adequadas à realidade local. Nesta adaptação devem ser considerados aspectos sociais (culturais e educacionais, por exemplo), do meio físico, restrições financeiras, entre outras.

. Gestão participativa. Todo o processo de gestão de RSU deve ser aberto ao público e receber contribuições da população e dos demais agentes sociais de forma participativa. Para tanto, deve existir trabalho, amplo e permanente, de mobilização da comunidade. 
Quadro 2 - Princípios de sustentabilidade aplicados à gestão dos RSU. cont.

- Democratização da informação. A população deve ser esclarecida quanto às questões associadas aos RSU, incluindo as conseqüências para o ambiente e a saúde humana do consumo excessivo e do desperdício; o uso de produtos menos impactantes deve ser incentivado.

- Garantia de condições adequadas de trabalho. Deve ser dada especial atenção, pelos diferentes operadores envolvidos na gestão dos RSU, às condições para a realização do trabalho. Aspectos tais como segurança, ergonomia e valorização do trabalho devem ser levados em consideração.

- Geração de trabalho e renda. As atividades associadas à recuperação de materiais dos RSU devem ser apoiadas e favorecidas pelo poder público, eliminando-se, também, situações de risco e de exploração dos agentes envolvidos, em especial, os mais vulneráveis. Em um quadro de desemprego, deve-se dar preferência a soluções intensivas em mão-de-obra, além de apoiar iniciativas comunitárias ou cooperativas, para equacionar problemas locais. Deve ser considerado, ainda, que as demais atividades relacionadas ao sistema, como coleta de resíduos e operação dos locais de disposição final, são atividades econômicas, também geradoras de emprego e renda.

. Preservação dos recursos naturais. Deve-se buscar a redução da geração de resíduos sólidos na fonte. Quando não for possível, deve-se procurar recuperar os materiais ou a energia presentes nos resíduos antes de sua disposição final. Para as diferentes etapas, o exemplo deve ser dado pelo próprio poder público, através de programas internos de redução de resíduos ou reciclagem.

- Previsão dos impactos socioambientais. Antes da realização de obras ou implantação de serviços vinculados à gestão dos RSU, deve-se prever e avaliar os possíveis impactos que tais ações terão sobre a sociedade e o ambiente. Deverá ser dada preferência à opção considerada mais benéfica, ou menos prejudicial, a partir dessas avaliações.

- Recuperação de áreas degradas pela gestão incorreta dos RSU. Deve-se investir na correção de situações negativas decorrentes de atividades de gestão dos RSU já realizadas.

- Poluidor pagador. Os custos da gestão dos RSU devem ser sempre explicitados, sendo assumidos pelos seus geradores, inclusive a população, de forma a que esta tenha consciência dos gastos necessários.

Fonte: modificado de MILANEZ e TEIXEIRA (2001) 
Princípios ou preceitos trazem em sua definição o significado de início, regra de conduta, norma, ensinamento que precede algo, que se apresenta no início.

A partir da proposição de princípios, como apresentado no Quadro 2, depara-se com a questão prática da avaliação e medição da sustentabilidade nos projetos, programa e ações relacionadas à gestão dos resíduos sólidos urbanos, como é o caso de programas de coleta seletiva. Esse é um tema do qual emerge a necessidade de pesquisar e estudar critérios para definição de indicadores.

\subsection{Minimização de Resíduos Sólidos}

A minimização de resíduos compreende um conjunto de estratégias que permitem a redução ou eliminação de contaminantes, em diferentes etapas do processo (CEPIS 1997).

A minimização de resíduos sólidos baseia-se na adoção de técnicas que possibilitam a redução da sua carga poluidora, visando, principalmente, à prevenção da geração de resíduos perigosos e a utilização de alternativas de disposição que não incluam a destinação no solo (CETESB 1993).

Segundo THIESEN (2001), o conceito da minimização, aplicado ao gerenciamento de resíduos sólidos, envolve qualquer técnica, processo ou atividade que permita evitar, eliminar ou reduzir sua geração na fonte e, quando não for possível, reusar ou reciclar os resíduos gerados para vários propósitos.

Os principais objetivos almejados em um programa de minimização são: a redução da quantidade de material e energia desperdiçados; a redução na produção de resíduos, de sua complexidade e de seu lançamento ao ambiente.

Os princípios da minimização de resíduos têm sido aplicados aos resíduos de diversas naturezas, gerados em processos industriais, por apresentarem vantagens econômicas. Oferecem possibilidade de redução de custos de destinação associada à alteração qualitativa e quantitativa dos resíduos e, em alguns casos, à obtenção de receita adicional com a comercialização de subprodutos.

De acordo com a CETESB (1993), existem, basicamente, duas estratégias para minimização de resíduos: redução na fonte e reciclagem. 
No Brasil, tem-se adotado os princípios da minimização, no âmbito de programas de coleta seletiva de resíduos sólidos urbanos, a partir do princípio dos 3R's, que é traduzido em: Reduzir, Reutilizar e Reciclar .

Em termos de resultados práticos, tem-se observado que a adoção do princípio dos 3R's fica, na maioria das vezes, no campo da teoria, pois os programas de coleta seletiva trabalham efetivamente o terceiro $\mathrm{R}$, que é o da reciclagem.

A inclusão dos princípios de não geração e a redução de resíduos sólidos urbanos em programas de coleta seletiva são de fundamental importância para se obter ganhos ambientais e sanitários. Caso contrário corre-se o risco da população acreditar, ao participar da coleta seletiva, que: quanto mais lixo for reciclado melhor, o que leva ao aumento da produção de resíduos.

\subsection{Coleta Seletiva}

O processo de recuperação dos materiais recicláveis presentes nos resíduos sólidos inicia-se com a coleta seletiva.

A coleta seletiva pode ser definida como: a etapa de coleta de materiais recicláveis presentes nos resíduos sólidos urbanos, após sua separação na própria fonte geradora, seguido de seu acondicionamento e apresentação para coleta em dias e horários prédeterminados, ou mediante entrega em Postos de Entrega Voluntária, em Postos de Troca, a catadores, a sucateiros ou a entidades beneficentes.

De acordo com a SEDU (2002), as operações de coleta seletiva de recicláveis presentes no resíduo sólido urbano visam à interceptação do seu ciclo tradicional de manejo, evitando que estes materiais venham a se integrar ao conjunto heterogêneo e desuniforme em que consiste o lixo, dando aos mesmos um caminho diverso do usual, o que pode representar diversos ganhos para a sociedade, destacando-se entre eles:

a) manutenção das características originais dos materiais recicláveis, que representa a sua valorização, o que, em termos econômicos, é essencial para fazer frente aos custos operacionais de limpeza urbana;

b) racionalização e otimização dos equipamentos, sistemas e métodos de coleta e disposição final regulares;

c) contribuição para ampliação da vida útil dos aterros sanitários; 
d) geração de emprego e renda; e,

e) preservação de recursos naturais.

Ao ser descartado junto aos resíduos sólidos urbanos, o material reciclável perde qualidade, em função da contaminação oriunda de outros componentes do lixo (materiais orgânicos e inorgânicos), o que contribui para reduzir o seu potencial de recuperação.

A coleta seletiva de resíduos sólidos urbanos é uma atividade relativamente recente no Brasil e ainda não faz parte da rotina da grande maioria dos sistemas de limpeza pública municipais, normalmente vem sendo implantada e operada na forma de programa específico, sendo desenvolvida por iniciativa de grupos de cidadãos, entidades de natureza privada e/ou pelo poder público.

Dependendo da estratégia do programa de coleta seletiva, o acondicionamento dos materiais recicláveis poderá ser distinto para cada material componente dos resíduos sólidos, ou poderá ser único para todo o material reciclável, também denominado lixo reciclável e, inapropriadamente, lixo seco.

A terminologia lixo seco, quando adotada para denominar o grupo de materiais recicláveis a ser separado para coleta seletiva e, fazer a sua distinção da parcela do lixo domiciliar que é composta de matéria orgânica (lixo úmido), pode resultar no entendimento, por parte da população alvo do programa, de que todos os resíduos secos devam ser separados para a coleta seletiva. Levando a aumentar os percentuais de rejeitos presentes nos materiais recicláveis coletados.

Além de sua aplicação no gerenciamento de sistemas municipais de limpeza urbana, a coleta seletiva vem sendo gradativamente implantada em outros locais como: empresas, clubes, escolas, igrejas, entre outros, tornando-se, atualmente, um dos requisitos indispensáveis para a obtenção de certificação ambiental por parte de empresas.

Ainda de acordo com o CEMPRE (1999) a elaboração, implantação e operação de um programa de coleta seletiva pode ser sistematizado nas seguintes fases:

Fase de Diagnóstico: envolve pesquisas e estudos relativos ao perfil sociocultural da população que se deseja trabalhar, às características dos resíduos sólidos, ao 
conhecimento do mercado de sucatas local, à identificação de outros projetos de coleta seletiva em operação, à avaliação de tecnologias disponíveis para reciclagem dos materiais triados, à identificação de fontes de financiamento e à avaliação de impacto ambiental da implantação do projeto;

Fase de Planejamento: envolve a definição do modelo ou modelos de coleta seletiva a serem adotados, a abrangência geográfica do programa, a estratégia de educação, sensibilização e conscientização da população, a análise de custos operacionais fixos e variáveis, o dimensionamento da coleta (mão-de-obra, veículos e recipientes), a listagem de compradores de sucatas encontrados em distâncias que tornem viável o custo de frete, o estabelecimento de parcerias e a avaliação de viabilidade quanto à formação de consórcios com municípios vizinhos;

Fase de Implantação: envolve a periodicidade da coleta, a instalação de equipamentos de apoio como, por exemplo, os recipientes, a preparação da infraestrutura de apoio logístico (galpão de triagem, área de armazenamento, equipamentos para redução de volume e outros), a capacitação do pessoal envolvido, inclusive com assistência social e, quando for o caso, a estratégia de divulgação e a definição da mídia empregada;

Fase de Operação e Monitoramento: envolvem a avaliação dos indicadores de desempenho, os investimentos constantes em informação e para estimular a participação da população e o acompanhamento do mercado de recicláveis para escoamento dos materiais coletados

Fase de Análise de Benefícios: envolve a contabilidade de receitas ambientais, de receitas econômicas e de receitas sociais.

Todas as fases apresentadas são importantes para o desenvolvimento e a sustentabilidade de um programa de coleta seletiva.

Observa-se que três modalidades de coleta seletiva de resíduos sólidos urbanos têm sido utilizadas com maior ênfase nos diversos programas existentes no país:

Coleta Seletiva em Postos de Entrega Voluntária, na qual o próprio gerador desloca-se até um Posto de Entrega Voluntária, também denominado de Local de Entrega Voluntária, PEV, LEV ou ECOPOSTO, e deposita o material reciclável, previamente triado, em recipientes para resíduos diferenciados por tipos de materiais; 
Coleta Seletiva Porta a Porta, na qual o material reciclável, previamente segregado por tipo ou não, acondicionado e apresentado à coleta pelo gerador é coletado por veículos dimensionados para realizar tal tarefa, ainda, na porta da residência do contribuinte. Esse sistema traz maior comodidade aos cidadãos; e,

Coleta Seletiva por Trabalhadores Autônomos da Reciclagem, na qual um grupo de trabalhadores autônomos, em geral apoiado e/ou gerenciado por alguma organização de caráter social, com ou sem o apoio logístico do poder público, recolhe o material reciclável disposto em via pública, oriundo de domicílios, ou gerado em estabelecimentos comerciais, de serviços ou em indústrias, previamente segregado por tipo ou não, utilizando-se, normalmente, de carrinhos de tração manual.

Tal modalidade de coleta seletiva pode ser subdividida em:

- Coleta Seletiva por Carrinheiros: na qual o trabalhador autônomo atua de forma isolada ou em pequenos grupos, geralmente, formados por membros da mesma família e vende o produto do seu trabalho a sucateiros. Algumas vezes, estes sucateiros fornecem o carrinho de tração humana em comodato ao trabalhador; e,

- Coleta Seletiva por Organização de Trabalhadores Autônomos da Reciclagem: na qual um grupo de trabalhadores autônomos une-se para formar algum tipo de organização (associações ou cooperativas de trabalho), visando garantir melhores condições de trabalho e renda para todos.

Em alguns casos, a administração municipal, visando fomentar a inserção social de população de rua e pessoas desempregadas, ou mesmo dos catadores de lixões, apóia tais organizações. Para tanto, aloca recursos logísticos (local de trabalho para os indivíduos organizados) e infra-estrutura necessária (equipamentos e material) para operacionalização da coleta e triagem de materiais, sendo todo o recurso gerado revertido para a geração de renda destes trabalhadores.

Nas modalidades de coleta seletiva por meio de Postos de Entrega Voluntária e Porta a Porta, o material reciclável recolhido é transportado para um centro de classificação e pré-beneficiamento, de onde sairá para posterior doação ou comercialização. Esse local é, normalmente, conhecido como Centro de Triagem de resíduos sólidos. 
$\mathrm{Na}$ Coleta Seletiva por Organizações de Trabalhadores Autônomos da Reciclagem, o material recolhido, em geral, é transportado até um Galpão de Triagem e Beneficiamento, operado pelos próprios catadores, e, posteriormente, encaminhado à comercialização ou às indústrias recicladoras pela própria organização, sem interferência do poder público.

No estabelecimento de um Programa de Coleta Seletiva, cada município deveria adotar o sistema mais adequado de coleta seletiva de resíduos sólidos urbanos, considerando-se as características e as condições locais.

No Quadro 3 são apresentados aspectos positivos e negativos das principais modalidades de coleta seletiva utilizadas no país.

Quadro 3 - Aspectos positivos e negativos das modalidades de coleta seletiva.

\begin{tabular}{|c|c|c|}
\hline $\begin{array}{l}\text { Modalidade de } \\
\text { coleta seletiva }\end{array}$ & Aspectos positivos & Aspectos negativos \\
\hline Porta a Porta & $\begin{array}{l}\text { Geralmente, os recicláveis são } \\
\text { agrupados visando facilitar a sua } \\
\text { separação na fonte geradora e } \\
\text { posterior disposição na calçada do } \\
\text { contribuinte; } \\
\checkmark \text { Dispensa o deslocamento do cidadão } \\
\text { até um Posto de Entrega Voluntária, } \\
\text { o que influi positivamente quanto à } \\
\text { participação na coleta seletiva; } \\
\checkmark \text { Permite mensurar a participação da } \\
\text { população no programa pela } \\
\text { facilidade de se identificar os } \\
\text { domicílios e estabelecimentos } \\
\text { participantes; } \\
\checkmark \text { Agiliza a descarga nas centrais de } \\
\text { triagem. }\end{array}$ & $\begin{array}{l}\text { Exige maior infra-estrutura de } \\
\text { coleta, representada pelo aumento } \\
\text { da frota de veículos e recursos } \\
\text { humanos; } \\
\checkmark \quad \text { Tende a apresentar custos mais } \\
\text { altos de coleta e transporte } \\
\text { comparado com outras } \\
\text { modalidades de coleta seletiva; } \\
\checkmark \\
\text { Atrai a presença de maior número } \\
\text { de catadores na região onde está } \\
\text { implantada (questão social). }\end{array}$ \\
\hline
\end{tabular}


Quadro 3 - Aspectos positivos e negativos das modalidades de coleta seletiva. cont.

\begin{tabular}{|c|c|c|}
\hline $\begin{array}{l}\text { Modalidade de } \\
\text { coleta seletiva }\end{array}$ & Aspectos positivos & Aspectos negativos \\
\hline $\begin{array}{l}\text { Posto de Entrega } \\
\text { Voluntária }\end{array}$ & $\begin{array}{l}\checkmark \text { Maior facilidade e menor custo de } \\
\text { coleta; } \\
\checkmark \text { Possibilita a redução de custos de } \\
\text { coleta e transporte, com otimização } \\
\text { de percursos e freqüências, } \\
\text { especialmente, em bairros com } \\
\text { população esparsa; } \\
\checkmark \text { Permite a exploração do espaço do } \\
\text { Posto de Entrega Voluntária com } \\
\text { publicidade e eventual obtenção de } \\
\text { patrocínio; } \\
\checkmark \text { Em função do tipo de recipiente e } \\
\text { estímulo educativo adotados, } \\
\text { permite a separação e o descarte de } \\
\text { recicláveis, por tipos, facilitando a } \\
\text { triagem posterior. }\end{array}$ & $\begin{array}{l}\checkmark \text { Requer maior disponibilidade da } \\
\text { população, que deverá se deslocar } \\
\text { até um Posto de Entrega } \\
\text { Voluntária para participar; } \\
\checkmark \text { Suscetível a vandalismo (desde o } \\
\text { depósito de lixo orgânico e } \\
\text { animais mortos no interior de } \\
\text { recipientes de coleta até a } \\
\text { danificação de sua estrutura); } \\
\checkmark \text { Exige manutenção e limpeza } \\
\text { periódicas; } \\
\checkmark \text { Necessita, em alguns casos, de } \\
\text { equipamento especial para coleta; } \\
\checkmark \text { Não possibilita a identificação dos } \\
\text { domicílios e estabelecimentos } \\
\text { participantes; } \\
\checkmark \text { Dificulta a avaliação da adesão } \\
\text { da comunidade ao programa. }\end{array}$ \\
\hline $\begin{array}{l}\text { Trabalhadores } \\
\text { autônomos da } \\
\text { reciclagem }\end{array}$ & $\begin{array}{ll}\checkmark & \text { Promove a inclusão social; } \\
\checkmark & \text { Gera emprego e renda; } \\
\checkmark & \text { Reduz o custo de coleta, transporte, } \\
& \text { triagem e destinação final de } \\
& \text { resíduos sólidos urbanos para a } \\
& \text { administração municipal; } \\
\checkmark & \text { Em relação às demais modalidades } \\
\text { de coleta seletiva, apresenta maior } \\
\text { independência e menor } \\
\text { vulnerabilidade às descontinuidades } \\
\text { das administrações municipais. }\end{array}$ & $\begin{array}{l}\checkmark \text { Está direcionado para materiais } \\
\text { com maior valor de mercado; } \\
\checkmark \text { Apresenta elevado risco de } \\
\text { acidentes, principalmente, quando } \\
\text { trabalhadores atuam sem } \\
\text { equipamentos de sinalização de } \\
\text { trânsito e de proteção individual; } \\
\checkmark \\
\text { Dificulta a mensuração da } \\
\text { participação da população; } \\
\checkmark \text { Contribui negativamente para a } \\
\text { manutenção da limpeza urbana, da } \\
\text { saúde pública, uma vez que são } \\
\text { danificadas embalagens de lixo } \\
\text { devido à procura de materiais } \\
\text { recicláveis, promovendo o seu } \\
\text { espalhamento nas áreas públicas; } \\
\checkmark \text { Em alguns casos, é explorada a } \\
\text { mão de obra do trabalhador e/ou o } \\
\text { trabalho infantil. }\end{array}$ \\
\hline
\end{tabular}

FONTE: modificado de GRIMBERG e BLAUTH (1998)

Dependendo da estratégia do programa de coleta seletiva, a população pode ser orientada a segregar o resíduo na fonte, acondicionando em separado cada tipo de material ou grupo de materiais (papéis, plásticos, metais, vidros e outros) ou a 
agrupar os seus resíduos em dois grupos: materiais recicláveis; e os demais resíduos, incluindo matéria orgânica.

Durante a etapa de pesquisa documental constatou-se a carência de informações confiáveis sobre coleta seletiva, o que tem levado técnicos e pesquisadores do setor a enfatizar a necessidade de se buscar padronização na apresentação de experiências, fundamentais para comparações e análises que possam subsidiar a implantação de novos programas e o planejamento e execução de políticas e ações mais adequadas para o setor.

AGUIAR e PHILLIP JR. (2000), ao analisarem diretrizes para a estruturação de programas de coleta seletiva, abordam a dificuldade, por parte dos organizadores, de ampliar o alcance e os resultados efetivos dos programas quanto à recuperação de materiais e à economia de espaço e de custos operacionais em aterros sanitários. Esses autores propõem a utilização de ferramentas de planejamento e gerenciamento de projetos nas fases de planejamento, execução e controle de programas de coleta seletiva, as quais podem ser simples e eficazes.

As pesquisas realizadas no país sobre a coleta seletiva, geralmente, têm se concentrado nos aspectos econômicos e operacionais da questão, não aprofundando, com a mesma ênfase, a análise da avaliação dos aspectos sociais, de divulgação dos programas e da participação da população, como, também, da qualidade dos serviços oferecidos.

Essa avaliação é relevante para a etapa de planejamento de um Programa de Coleta Seletiva, com o objetivo de se definir indicadores ou parâmetros. Aspecto como a expectativa da participação da população é de difícil mensuração uma vez que tal informação depende basicamente do perfil sócio-econômico e cultural da população, da eficiência da estratégia de marketing adotada para sensibilização e motivação da população envolvida, da adequação do projeto à realidade local e também da regularidade no funcionamento da logística implantada para dar suporte ao sistema.

É importante que o Programa de Coleta Seletiva implantado seja complementado com programas de educação ambiental, que levem os indivíduos envolvidos a adotarem medidas para minimização da geração de resíduos, contribuindo com a administração pública e/ou privada, no sentido de equacionar esta questão. 
Assim, a avaliação dos fatores envolvidos no planejamento e na implantação de Programas de Coleta Seletiva contribui, decisivamente, para que sejam adotadas diretrizes adequadas, em especial, quanto aos fatores que interferem no seu custo de implantação e operação e na efetiva adesão da população ao programa.

\subsection{Participação Social}

A mobilização da comunidade para participar pode ser considerada uma das etapas mais importantes e complexas na implantação de programas, projetos e ações que envolvem mudanças nas rotinas e/ou nos hábitos dos indivíduos.

De acordo com SILVA e LEITE (2001), a forma pela qual os seres humanos participam de qualquer ecossistema, depende da estrutura e composição desse ecossistema e também da bagagem cultural dos envolvidos, daquilo que eles e seus descendentes recebem e em seguida difundem, existindo diferenças entre as imagens que eles fazem e a estrutura real dos ecossistemas.

Os autores consideram ainda que a vida nas cidades, nos chamados ecossistemas urbanos, muitas vezes não propicia um convívio natural e descontraído entre os seus habitantes, afastando-os de um relacionamento pessoal mais integrado, originando o anonimato. Este fator produz um distanciamento entre as pessoas e o espaço em que vivem, desvinculando o indivíduo do seu entorno e acarretando descompromisso com a preservação e qualidade do ambiente.

A partir de 1991, CRESPO (2003) realizou três pesquisas enfocando a questão: $O$ que o brasileiro pensa da ecologia. Verificou que independente de fatores como classe social, escolaridade, cor, sexo e religião, os brasileiros consideram o meio ambiente como sinônimo de fauna e flora. Este dado manteve-se constante nas pesquisas realizadas em 1992, 1997 e 2001.

A autora constatou ainda que quando os brasileiros pensam em meio ambiente deixam de fora tudo que se relaciona aos seres humanos e às suas criações.

Nesse contexto, temas como saneamento e resíduos sólidos não têm um grande apelo junto à população. Para o indivíduo brasileiro, no perfil encontrado pela pesquisadora, ser ambientalmente correto não implica mudar ações no cotidiano. Um exemplo clássico é o apoio que a população afirma dar, em pesquisas de opinião, à reciclagem, 
sua baixa participação efetiva em programas de coleta seletiva e o hábito de jogar tudo o que pode em vias públicas, encostas e corpos hídricos.

Os estudos de CRESPO (2003) também envolveram os aspectos do consumo e concluíram que a maioria dos brasileiros tem motivação para consumir produtos ambientalmente corretos e buscam um estilo de vida mais saudável, associam a idéia que qualidade de vida implica em hábitos mais saudáveis. O estudo ressalta ainda que a resposta atribuída à questão sobre qual o objetivo da motivação em proteger o meio ambiente e os recursos naturais, em 1992, era predominantemente porque é bom para a saúde humana. A autora sugere que o elo da saúde, qualidade de vida e meio ambiente talvez seja uma relação mais facilmente percebida pela população.

Analisando sob outro ponto de vista, PORTILHO (2004) discute a adoção de estratégias de busca de soluções para problemas ambientais, decorrentes de consumo e estilo de vida, que focam apenas o papel do consumidor. O autor defende a idéia de que as responsabilidades pela resolução de problemas ambientais deveriam ser atribuídas a diferentes atores sociais. Fazendo um paralelo com as práticas adotadas em nossa sociedade, considera inadequada a estratégia da transferência da responsabilidade do Estado para o mercado e do Estado e do mercado para o consumidor individual. Neste contexto, os consumidores individuais, conscientes, bem informados e motivados por valores ambientais, estariam sendo vistos como os responsáveis pela melhoria das condições ambientais através de suas escolhas cotidianas.

A autora propõe a estratégia do Consumo Sustentável, o qual enfatiza mais as ações coletivas e as mudanças políticas e institucionais do que as ações tecnológicas, econômicas e comportamentais, visando sensibilizar o consumidor para pensar como cidadão. E conclui: Consumo e cidadania devem ser vistos de forma conjunta e inseparável!

Outro aspecto relevante a considerar quanto à participação social é a percepção ambiental. SILVA e LEITE (2001) atribuem à percepção inadequada da realidade a responsabilidade por vários problemas relativos à utilização dos recursos naturais de maneira insustentável, fruto da falta de preocupação com as gerações futuras, ameaçando a continuidade da vida no Planeta Terra. Esses problemas precisam ser 
vistos como diferentes facetas de uma única crise, que é, em grande medida, uma crise de percepção.

Infelizmente, de maneira geral, nos programas de coleta seletiva, a intervenção junto ao público alvo acontece a partir da percepção dos técnicos envolvidos, o que faz com que muitos desses projetos não alcance os objetivos propostos, principalmente o de envolver e motivar a participação social.

Segundo VILELLA (2001), não se pode desenvolver qualquer programa vinculado a sustentabilidade e a proteção ambiental sem o envolvimento dos cidadãos. Caso os conceitos por trás dos programas não sejam devidamente assimilados, por mais bem intencionados e por melhor elaborados que sejam, não estarão inseridos nas atividades do dia-a-dia da população, resultando em baixa eficácia.

Estes conceitos precisam ser internalizados, uma vez que não são as leis que provocam os impactos sobre o meio ambiente, mas o comportamento das pessoas.

Cabe pontuar a importância de se levar em conta os valores sociais nas tomadas de decisão. É fundamental observar as diferenças entre a percepção de um mesmo problema pelos técnicos e pelos indivíduos envolvidos.

Antes de qualquer intervenção é necessário identificar qual a percepção que a comunidade envolvida tem sobre o ambiente, como ela percebe a relação ser humanomeio ambiente, caso contrário, o trabalho poderá não alcançar os objetivos esperados. $\mathrm{Na}$ busca do entendimento das relações existentes entre o indivíduo e o meio, BINSWAGNER (1973) e SVENSON (1981) apud PILON (1998) apresentam sistematização das relações entre o Homem e as quatro dimensões de Mundo, divididas em: intima, interativa, social e biofísica, integradas e interdependentes. $\mathrm{O}$ Quadro 4 apresenta tal sistematização: 
Quadro 4 - Relações entre o Homem e as quatro dimensões de mundo

Dimensão íntima: envolve sujeitos enquanto mediadores de variáveis subjetivas (motivos, expectativas, desejos, sentimentos e razões) e objetivas (oportunidades, normas, redes de relações, matéria e energia); expressa ofertas (internas) e demandas (externas) na forma de cognições, afetos e ações.

Dimensão interativa: envolve grupos, rede de relações imediatas (grupos primários) das quais os sujeitos fazem parte (ou pretendem fazer parte), abrangendo familiares, colegas, amigos e pessoas associadas, mediante objetivos comuns (trabalho, lazer, crença, arte, estudo, atividades marginais, entre outros.); constitui os "grupos de referência", às vezes simbólicos.

Dimensão social: envolve sociedades e culturas que as sustentam, compreendendo organização política, econômica e social, respectivas políticas e ideologias (hegemônicas ou não), direitos e deveres (cidadania), sanções e recompensas (controle); constitui o espaço público.

Dimensão biofísica: envolve matéria e energia, a biosfera (e o próprio homem enquanto corpo), natureza e ecúmenos (assentamentos, cidades, campos), "ar, água, terra e fogo", obras de engenharia, arquitetura, paisagem e ambiente, espaços e cosmos; constitui o entorno e os corpos nele presentes.

Fonte: BINSWAGNER (1973) e SVENSON (1981) apud PILON (1998)

Os autores concluem que, em uma visão sistêmica, essas quatro dimensões não atuam isoladamente, a existência de uma necessariamente depende das demais. Toda intervenção que se venha a realizar junto à população deveria contemplar essas dimensões e suas inter-relações, gerando um trabalho integrado.

Além de se considerar a percepção ambiental do público alvo do programa, para se obter melhores resultados na etapa de mobilização da comunidade, os organizadores devem adotar alguns princípios básicos de credibilidade tais como: honestidade ao tratar da população, ouvir a opinião das pessoas envolvidas, falar de forma simples, reconhecer o que é ou não objetivo, reconhecer valores, ter consistência e admitir opiniões contrárias. Em suma, nesses casos a racionalidade técnica não funciona e as campanhas de combate ao fumo são um exemplo claro dessa questão. 
GRIMBERG e BLAUTH (1998) acreditam que o comportamento humano só muda se mudarem também os valores e os sentimentos que o sustentam; e que campanhas não mudam comportamento de forma duradoura.

A maioria dos programas de coleta seletiva atribui grande importância à educação ambiental como meio de fazer os indivíduos separarem o lixo, entretanto, não incorporam no seu planejamento os recursos humanos e financeiros necessários ao desenvolvimento do processo de construção de novos valores sociais e ambientais que tal atividade requer.

Segundo NUNESMAIA (1995), a educação ambiental é um instrumento importante de gestão dos resíduos sólidos, porém acertar na escolha metodológica não tem sido uma tarefa fácil, sendo necessário considerar as peculiaridades de cada região.

Convencer as pessoas sobre a importância de sua contribuição individual na solução de problemas cuja escala extrapola o seu cotidiano para garantir um futuro sustentável é tarefa de longo prazo.

\subsection{Programas de Coleta Seletiva no Brasil}

Apesar da mídia freqüentemente explorar o tema, a maior parte das iniciativas e ações de coleta seletiva no Brasil é informal. No país há programas de coleta seletiva operando em apenas 3,5\% dos 5.561 municípios brasileiros, o que corresponde a 192 experiências implantadas e em funcionamento, conforme demonstra pesquisa sobre o tema, denominada pesquisa CICLOSOFT, realizada em 2002 pelo Compromisso Empresarial para Reciclagem - CEMPRE (2003).

Existem iniciativas positivas relativas à coleta seletiva no país, entretanto, o quadro geral apresentado pelos municípios brasileiros quanto à gestão dos resíduos sólidos urbanos é grave. Descontinuidade política e administrativa, limitações financeiras e orçamentos inadequados, tarifas/taxas desatualizadas, arrecadações insuficientes e recursos humanos com baixa capacitação técnica são fatores que contribuem para essa gravidade.

Em 2002, a Secretaria de Desenvolvimento Urbano (SEDU), do governo federal, contratou um amplo estudo sobre a coleta seletiva no país, denominado: Avaliação Técnico-Econômica e Social de Sistemas de Coleta Seletiva de Resíduos Urbanos 
existentes no Brasil (SEDU 2002). O estudo foi realizado pelos pesquisadores da PUC-PR/ISAM que avaliaram 94 programas de coleta seletiva de RSU para a reciclagem no país, sendo 66 através de respostas a questionário enviado e 28 por outras fontes, além de visitas técnicas aos municípios. Os pesquisadores verificaram que a maioria desses programas relaciona-se a experiências piloto, iniciativas pontuais organizadas pelo poder público, pela iniciativa privada, $\mathrm{ONG}^{\prime} \mathrm{S}$, associações de moradores, de bairros e/ou condomínios, atendendo apenas a parte das áreas urbanas, ou desenvolvidas em escolas, bairros e condomínios.

A pesquisa identificou que, na maior parte dos municípios com programa/projeto de coleta seletiva, os dados referenciais e estatísticos encontram-se dispersos, não sistematizados, sendo a identificação de pessoal responsável pela coleta seletiva extremamente difícil, existindo grande variedade de órgãos ou instituições executoras. O conceito de um programa integrado entre a coleta seletiva e a limpeza urbana ainda é incipiente na maioria dos municípios brasileiros pesquisados, sendo que 59,1\% conta com projetos/programas que atendem apenas parcialmente o município. Iniciativas de maior abrangência situam-se em cidades de porte médio e em algumas capitais brasileiras.

Foi verificado que o pessoal envolvido com a coleta seletiva desconhece o custo unitário da tonelada dos materiais recicláveis coletados em suas regiões e foi estimado que, em $63,3 \%$ dos municípios pesquisados o custo operacional da coleta seletiva é maior que a arrecadação de recursos com a comercialização dos recicláveis.

Os pesquisadores atribuíram a relação deficitária entre custo e receita relativos à coleta seletiva ao elevado custo da operação de coleta, ao mercado desfavorável para comercialização dos materiais triados e à sua qualidade insatisfatória. Constataram a falta de estudos mais detalhados sobre a caracterização dos RSU e conseqüentemente dos resíduos recicláveis.

Quanto à aplicação dos recursos financeiros arrecadados, os pesquisadores encontraram, como valores médios dos municípios pesquisados, que o percentual dos recursos investidos na manutenção da coleta seletiva é cerca de 25,8\% e em promoção de atividades assistenciais, 15,2\%. Outras aplicações acontecem como: distribuição de renda entre os envolvidos, distribuição às populações carentes, cota 
parte aos cooperados, doações beneficentes, assistência aos catadores, medicamentos para a unidade sanitária local, obras públicas comunitárias, entre outras.

Nos resultados da pesquisa foi constatado que a mão-de-obra informal dos catadores, carrinheiros e carroceiros, presente em todas as cidades brasileiras, seria a grande força motriz da coleta seletiva. Essa catação informal é que abastece depósitos e aparistas os quais, por sua vez, alimentam as indústrias que utilizam materiais recicláveis. Os carrinheiros foram encontrados em 42,4\% dos municípios, seguidos dos carroceiros $(22,7 \%)$ e dos catadores $(8,0 \%)$. Os sucateiros estavam presentes em $40,9 \%$ e os aparistas em $30,3 \%$ dos municípios pesquisados, enquanto as organizações de trabalhadores autônomos da reciclagem foram encontradas em $39,4 \%$ desses municípios.

A coleta seletiva por meio dos PEVs, os quais promovem a participação direta da população na coleta seletiva, ainda está pouco difundida e consolidada no país. Os modelos de PEVs encontrados são os mais variados possíveis.

A maior parte das cidades pesquisadas pela SEDU (95,5\%) considera as ações de educação ambiental para a reciclagem como fundamentais para o êxito dos programas de coleta seletiva e vêem a reciclagem como instrumento de educação ambiental. A execução de folhetos, cartazes, faixas, palestras, seminários, atividades artísticas e caminhadas ecológicas constituem-se em elementos básicos das ações de educação ambiental desenvolvidas.

Os principais problemas levantados por essa pesquisa, relacionados à coleta seletiva, foram:

- falta de recipientes padronizados, depredação de recipientes,

- falta de veículo apropriado para a coleta seletiva,

- veículo utilizado para coleta não exclusivo, atendendo também a outros serviços;

- separação insuficiente entre material reciclável e orgânico;

- troca constante do pessoal envolvido na coleta;

- indiferença e falta de interesse da população,

- apresentação dos resíduos para coleta em horários inadequados;

- custo elevado na manutenção dos veículos. 
Ainda na pesquisa da SEDU (2002) encontra-se uma série de recomendações, dentre as quais merece destaque a necessidade de se desenvolver e apoiar a realização de estudos para apropriação dos custos de gerenciamento dos programas/projetos de coleta seletiva de resíduos sólidos urbanos para a reciclagem.

Mais recentemente tem-se observado, em todos os níveis de governo do país, a tendência de se conferir maior atenção à questão da gestão dos resíduos sólidos, sendo que os técnicos envolvidos com o tema têm alertado para a necessidade da criação de uma política nacional para tratar da questão de forma adequada, associada ao engajamento da sociedade, para reverter o quadro atual apresentado pelo manejo dos resíduos sólidos no país, a qual teria reflexos positivos para a coleta seletiva.

A questão do adequado gerenciamento da coleta seletiva extrapola o aspecto de custo, envolvendo fatores de ordem técnica, administrativa e comportamental.

Neste ensejo, CAMPOS (1994) propõe a aplicação de técnicas de gestão empresarial, de planejamento estratégico, que possibilitariam aos responsáveis por programas de coleta seletiva tomar decisões e concentrar-se no que é essencial, proporcionando maior harmonia no esforço conjunto onde cada um, inclusive os cidadãos, deve cumprir o seu papel para que programas de coleta seletiva se desenvolvam.

CAMPOS (1994) desenvolve estudo de caso na cidade de Ribeirão Preto (SP), no qual analisa o gerenciamento de serviços municipais de coleta seletiva a partir de um grupo de indicadores. $\mathrm{O}$ autor formula, a partir da estruturação das respostas obtidas em entrevistas realizadas com os técnicos responsáveis pelo sistema de limpeza pública da prefeitura municipal, matrizes que representam diversos aspectos gerenciais da coleta seletiva.

As Figuras 1 a 4 apresentam algumas dessas matrizes cujos resultados são aplicáveis à avaliação de programas de coleta seletiva desenvolvidos em outras cidades brasileiras. Na Figura 1 são apresentados os objetivos da prefeitura, responsável pela limpeza urbana do município e os objetivos da gestão dos resíduos sólidos urbanos para a implantação do programa de coleta seletiva e identificadas as suas interfaces. 
Figura 1 - Matriz objetivos da Prefeitura X objetivos da gestão dos resíduos sólidos.

\section{Objetivos da Prefeitura}

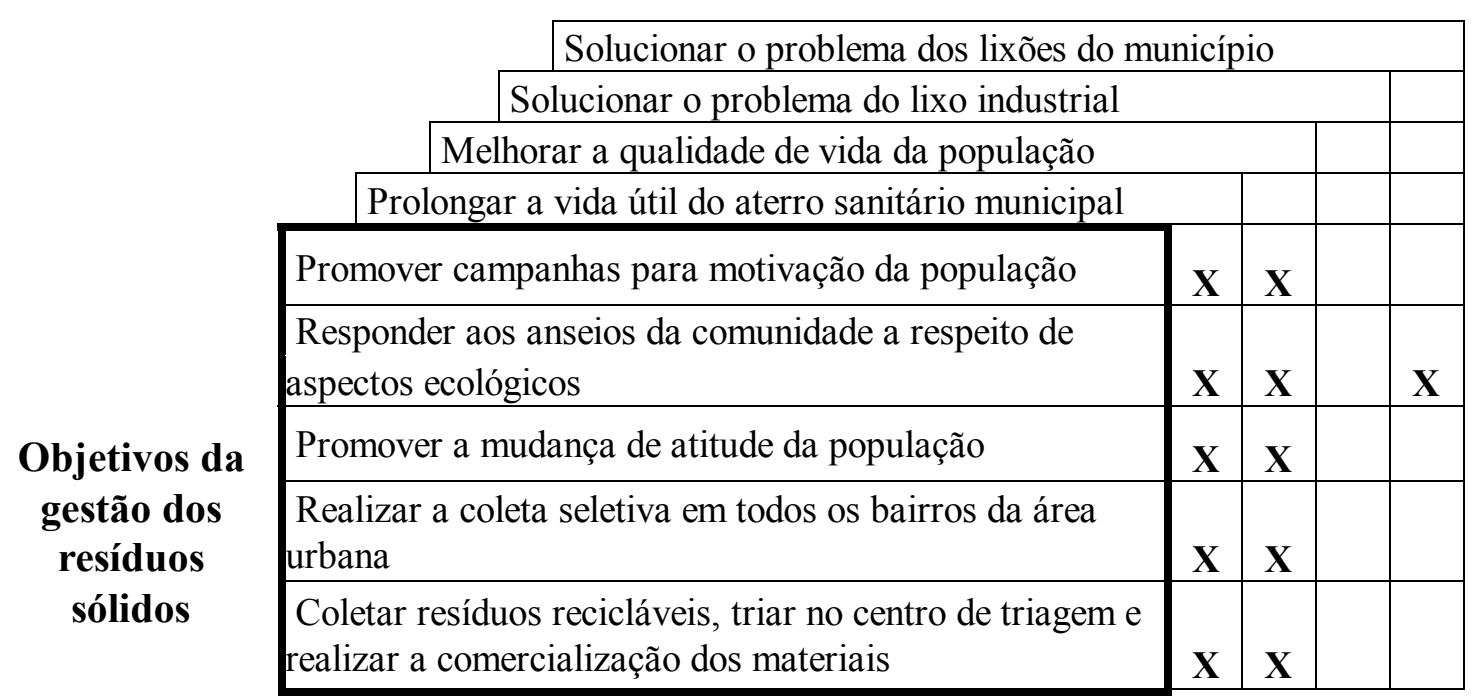

Fonte: adaptado de CAMPOS (1994)

Na Figura 2 são apresentados os objetivos levantados junto aos técnicos municipais responsáveis pela gestão dos resíduos sólidos no município, em relação aos fatores críticos de sucesso de programas de coleta seletiva estudado por CAMPOS (1994).

Observa-se que os objetivos da área de gestão de resíduos sólidos são os mesmos objetivos da gestão de resíduos sólidos apresentados na Figura 2 e acrescidos da melhoria do sistema de coleta seletiva existente.

Os fatores críticos de sucesso são etapas a serem cumpridas, de importância estratégica para o programa de coleta seletiva, que podem comprometer o seu sucesso caso não sejam adequadamente desenvolvidos. 
Figura 2 - Matriz objetivos da gestão dos resíduos sólidos na prefeitura $\mathrm{X}$ fatores críticos de sucesso da coleta seletiva

\section{Objetivos da gestão dos resíduos sólidos na prefeitura}

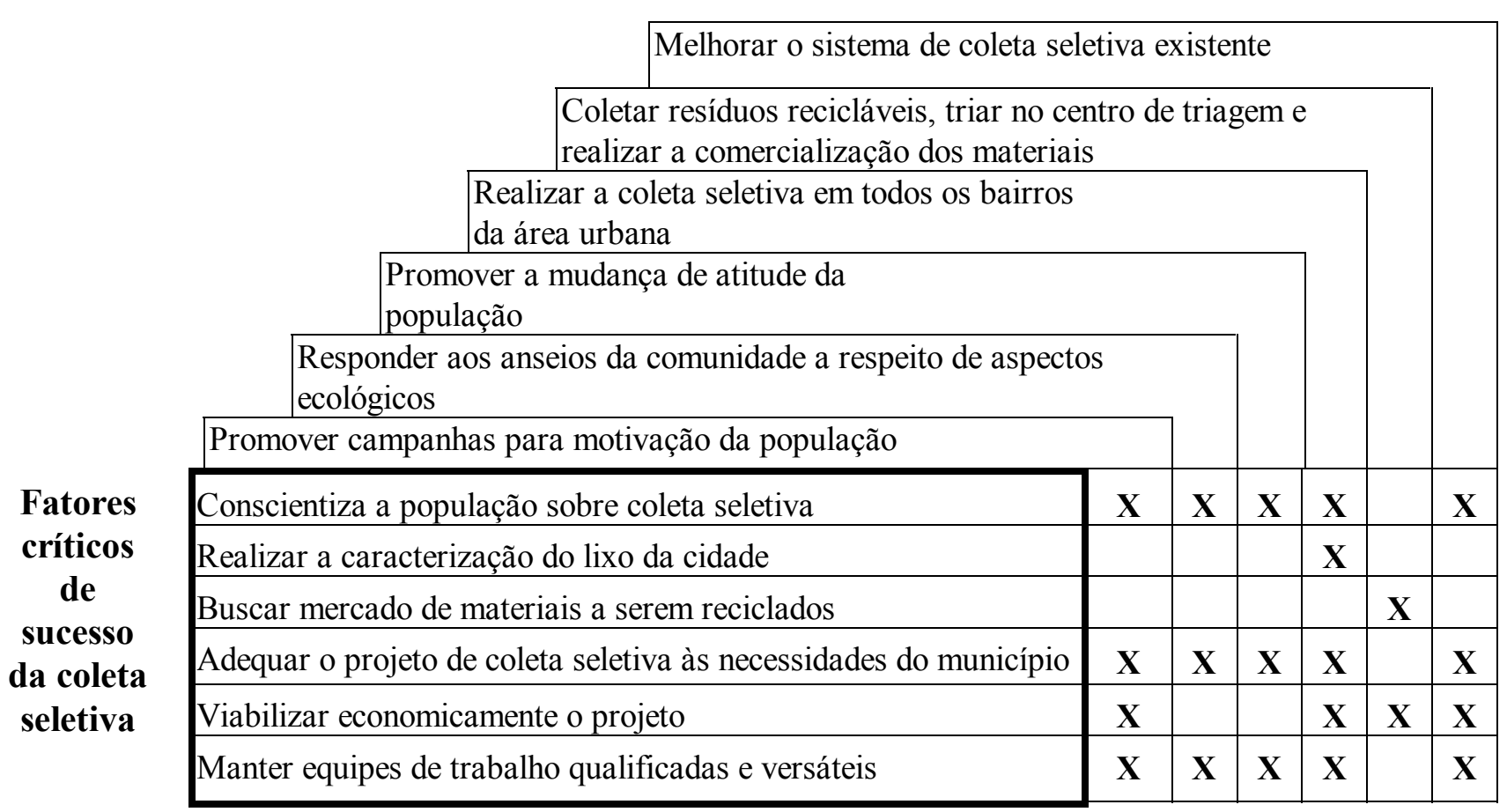

Fonte: adaptado de CAMPOS (1994)

Em seguida tem-se na Figura 3 a matriz onde os fatores críticos de sucesso estão cruzados com os problemas encontrados no programa de coleta seletiva da cidade de Ribeirão Preto (SP), estudado por CAMPOS (1994). 
Figura 3 - Matriz fatores críticos de sucesso da coleta seletiva X problemas da coleta seletiva

\section{Fatores críticos de sucesso da coleta seletiva}

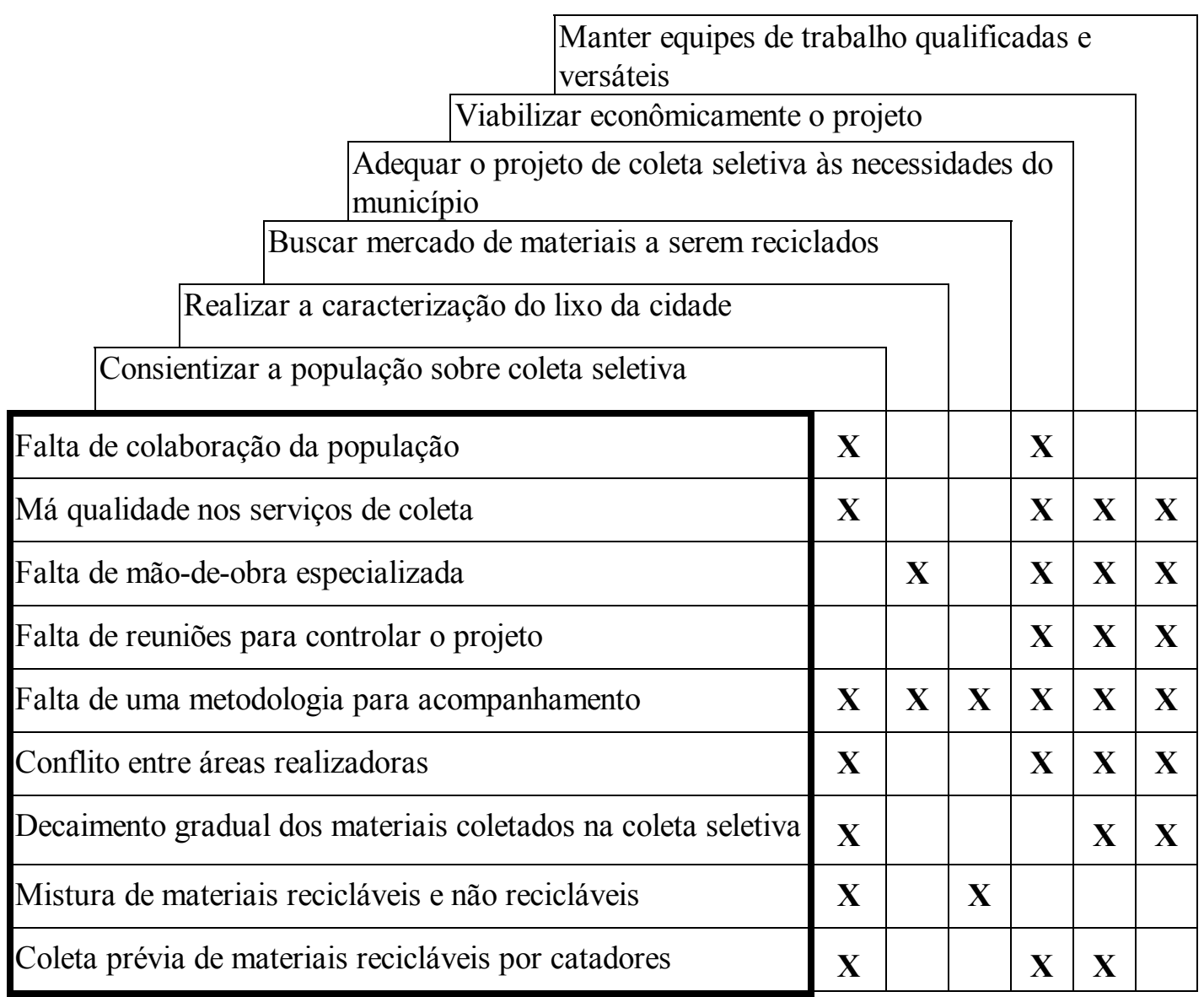

\section{Problemas da coleta seletiva}

Fonte: modificado de CAMPOS (1994)

Observa-se que os problemas e os pontos críticos levantados por CAMPOS (1994), ainda estão presentes na maioria dos programas de coleta seletiva implantados no país, constatando-se que houve pouca evolução de 1994 a 2004.

Para analisar tais problemas o autor elaborou uma matriz, apresentada na Figura 4, onde os fatores críticos de sucesso são avaliados em relação à necessidade de informação. 
Figura 4 - Matriz fatores críticos de sucesso da coleta seletiva X necessidades de informação

\section{Fatores críticos de sucesso da coleta seletiva}

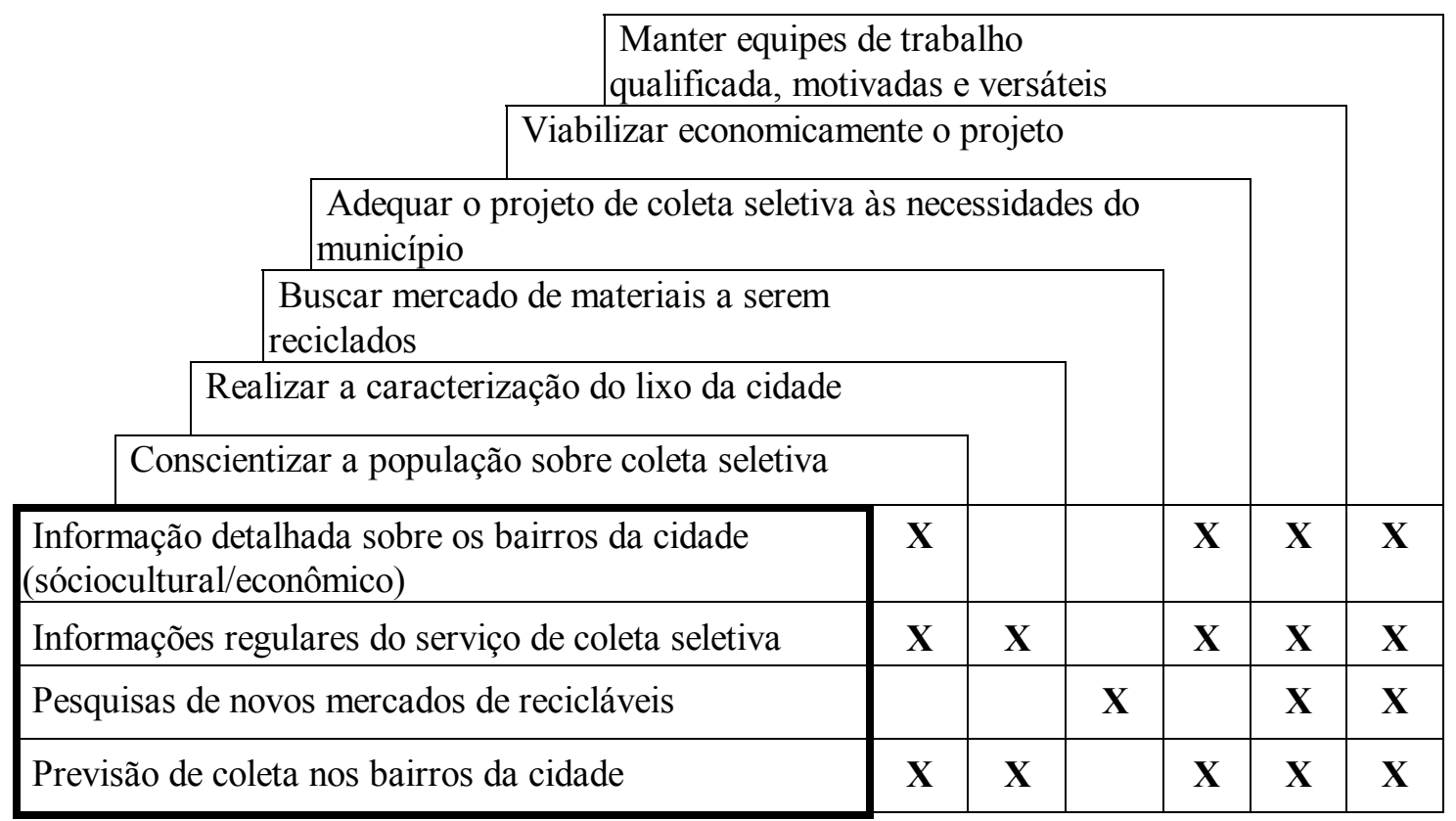

\section{Necessidade de Informação}

Fonte: modificado de CAMPOS (1994)

CAMPOS (1994) concluiu que para o bom desempenho de programas de coleta seletiva seria desejável que as informações gerenciais fossem levantadas continuamente e sistematizadas, a partir do uso de indicadores, permitindo acompanhar adequadamente o seu desenvolvimento.

\subsection{O Uso de Indicadores no Planejamento e Gestão da Coleta Seletiva}

Os indicadores possibilitam, a partir da informação sobre a situação existente, o estabelecimento de comparações entre realidades distintas, de modo a subsidiar a tomada de decisões sobre ações a recomendar ou a aplicar de imediato.

Segundo FRANCA (2001), o indicador pode ser definido como um parâmetro ou um valor derivado de outros parâmetros, que proporciona informação sobre um fenômeno tendo significado que se estende além das propriedades associadas ao valor do parâmetro em uso. 
Os indicadores, em geral, são utilizados com o propósito de se conhecer adequadamente uma situação existente para guiar os próximos passos e para tomada de decisão.

PEREIRA (1995) relata que, em estudos no campo da saúde e qualidade de vida, a utilização de indicadores tem sido importante para representar ou medir aspectos não sujeitos à observação direta.

O mesmo autor afirma, ao estudar indicadores de saúde, que os indicadores são efetivamente utilizados quando capazes de retratar com fidedignidade e praticidade, seguidos de preceitos éticos, os aspectos para os quais foram propostos e adota os seguintes critérios para sua avaliação:

- Validade - refere-se à adequação do indicador para medir ou representar, sinteticamente, o fenômeno estudado.

- Confiabilidade (reprodutibilidade ou fidedignidade) - refere-se à garantia de obtenção de resultados semelhantes, quando a mensuração é repetida.

- Representatividade (cobertura) - refere-se à cobertura alcançada pelo indicador em relação ao evento ou fenômeno estudado.

- Ética (obediência a preceitos éticos) - refere-se à garantia de que a coleta de dados não acarrete malefícios ou prejuízos às pessoas ou entidades investigadas; também relacionado ao sigilo quando se trata de dados individuais.

- Oportunidade, simplicidade, facilidade de obtenção e custo compatível - referemse ao fato de que a obtenção dos dados deve causar o mínimo de perturbação ou inconvenientes, ou seja, não deve interferir nas condições habituais de funcionamento dos serviços, além de ter custos compatíveis.

Os critérios de PEREIRA (1995) são aplicáveis em relação aos indicadores de coleta seletiva, inseridos no campo da saúde ambiental.

Outra possibilidade de se buscar indicadores compatíveis para programas de coleta seletiva seria no campo de conhecimento do desenvolvimento sustentável. Em 1990, um grupo de cidadãos americanos da cidade de Seatle reuniu-se para discutir a questão do desenvolvimento sustentado, traduzido na preocupação com: Que herança deixaremos para nossas gerações futuras. Assim, criaram o Fórum do 
Desenvolvimento Sustentado que definiu como estratégia: pesquisar e publicar indicadores de sustentabilidade.

Segundo ATKISSON (2003) inicialmente os organizadores do Fórum Seatle Sustentável estabeleceram critérios para enquadrar os indicadores de sustentabilidade a serem selecionados, considerando-se que um indicador deve:

- Refletir tendências fundamentais da saúde, cultura, econômia e meio ambiente a longo prazo;

- Ser estatisticamente mensurável e, preferencialmente, ter dados disponíveis há uma ou duas décadas;

- Ser atraente para a mídia local;

- Ser compreensível para as pessoas comuns.

O autor relata que, ao final de diversas rodadas de discussão, houve necessidade de se fazer algumas concessões sobre estes critérios para que se atingisse o consenso. Admitiram alguns indicadores complicados demais para a compreensão das pessoas comuns, com pouca probabilidade de atrair atenção da mídia, mas importantes para fins da política do grupo. Outros indicadores que não dispunham de dados históricos para análise imediata, mas avaliados como importantes, também foram adotados por se considerar que os mesmos não estariam recebendo a atenção adequada ao longo do tempo. Os indicadores considerados importantes, com possibilidade de sustentar dados históricos, foram adotados de imediato.

O resultado foi uma lista de 40 indicadores que contemplavam os temas: meio ambiente, população e recursos, economia, juventude e educação e saúde e comunidade. Em relação aos resíduos sólidos foram incluídos, no tema população e recursos, os indicadores: geração per capita e reciclagem per capita de resíduos sólidos.

A seleção de indicadores deve equilibrar exigências de sofisticação técnica e a capacidade do público de entender e responder às informações, balanceando os interesses ambientais, econômicos e sociais da comunidade. Na prática, porém, os indicadores somente passam a ser utilizados quando se apresentarem relevantes. 
No Brasil os temas ambientais não possuem tradição de produção estatística, fato esse atribuído em parte a pouca disponibilidade de informações da área ambiental para a construção desses dados. O Instituto Brasileiro de Geografia e Estatística - IBGE tem realizado estudos sobre indicadores de desenvolvimento sustentável, reunindo no tema saneamento os indicadores relacionados a abastecimento de água, esgotamento sanitário e coleta e destinação final de resíduos sólidos. Nessa abordagem não existem indicadores que tratam da coleta seletiva especificamente (BESSERMAN 2003).

O governo federal, visando ampliar o Sistema Nacional de Informação em Saneamento - SNIS, que tem disponibilizado dados de prestação de serviços de abastecimento de água e esgotamento sanitário desde 1995, tem desenvolvido esforços para incluir neste sistema a componente resíduos sólidos. Em 2003 foi realizada a primeira coleta de dados para um grupo específico de municípios, selecionados mediante critérios técnicos (MC 2003).

No questionário enviado aos municípios havia perguntas relativas aos diversos aspectos relacionados aos serviços de limpeza urbana, contendo questões sobre o serviço de coleta seletiva e triagem de materiais no município e sobre a situação dos catadores.

Por outro lado, a partir da revisão bibliográfica realizada na presente pesquisa, puderam ser identificadas algumas publicações que têm considerado os indicadores no planejamento e gestão da coleta seletiva no Brasil.

O CEMPRE, entidade que se destaca com relação ao levantamento e registro de informações sobre os programas de coleta seletiva existentes no Brasil, realizou em 1994, 1999 e em 2002 a Pesquisa CICLOSOFT na qual foram utilizados os seguintes indicadores:

- População atendida por serviços de coleta seletiva (hab)

- Escala da coleta seletiva ( $\mathrm{t} / \mathrm{mês})$

- Custo da coleta seletiva (US\$/t)

- Composição média, em peso, dos materiais recicláveis coletados

- Relação de despesa/receita

- Custo médio da coleta seletiva 
Outra publicação do CEMPRE (1999), o Guia da Coleta Seletiva de Lixo, apresenta alguns estudos de casos brasileiros que consideram o seguinte grupo de indicadores:

- Despesa com marketing e educação (R $\$$ / domicílio/ano)

- Paradas do caminhão por hora

- Custo de operação do veículo coletor por hora $(\mathrm{R} \$ / \mathrm{h})$

- População atendida (hab)

- Triagem dos materiais recicláveis $(\mathrm{kg} /$ funcionario/h)

- Custo operacional de triagem $(\mathrm{kg} / \mathrm{t})$

- Custo total da coleta seletiva $(\mathrm{R} \$ / \mathrm{t})$

- Relação de despesa/receita

Em 1998, o Instituto Polis editou a publicação Coleta Seletiva: Reciclando Materiais, Reciclando Valores, resultante de estudo sobre a coleta seletiva, realizado por GRIMBERG e BLAUTH (1998), no qual incluiu o aspecto social, inovação no tema, utilizando os seguintes indicadores:

- Total de resíduos sólidos (t/dia)

- Quantidade aterrada ( $\mathrm{t} / \mathrm{dia})$

- Quantidade coletada seletivamente (t/mês)

- Quantidade de rejeito da triagem (\%)

- Porcentagem de resíduos recuperados (\%)

- Taxa de desvio ou índice de recuperação de materiais (\%)

- Porcentagem da população atendida pela coleta seletiva (\%)

- Porcentagem do orçamento com a limpeza urbana (\%)

- Porcentagem do orçamento para a coleta seletiva (\%)

- Custo do programa $(\mathrm{R} \$ / \mathrm{t})$

- Custo da Coleta Convencional $(\mathrm{R} \$ / \mathrm{t})$

Em termos de pesquisas científicas desenvolvidas sobre o tema, há duas dissertações de mestrado defendidas no âmbito da Universidade de São Paulo que abordam a questão dos indicadores. CAMPOS (1994), que realizou seu trabalho junto à Escola 
de Engenharia de São Carlos, propõe indicadores globais, setoriais e elementares para o planejamento e a gestão de programas de coleta seletiva:

Indicadores Globais

- População urbana total da área de estudos

- Taxa de crescimento populacional anual (hab/ano)

- Densidade demográfica bruta (hab/hectare)

- Número de domicílios de habitação

- Número de domicílios comerciais

- Numero de domicílios escolares

- Produção total de resíduos coletados na área de estudo ( $\mathrm{kg} / \mathrm{dia})$

Indicadores Setoriais

- Produção média de resíduos sólidos por habitante ( $\mathrm{kg} / \mathrm{hab} / \mathrm{dia})$

- Atendimento da coleta seletiva (\%)

- Freqüência média da coleta Seletiva (número de coletas/semana)

- Produção média de resíduos sólidos coletados seletivamente (\%/mês)

- Proporção dos resíduos sólidos domésticos (\%)

- Proporção dos resíduos sólidos em domicílios comerciais (\%)

- Proporção dos resíduos sólidos em domicílios escolares (\%)

- Proporção de reciclagem

Indicadores Elementares

- População participativa (\%)

- Confiabilidade - nível de satisfação do usuário (reclamações/mês)

- $\quad$ Assimilação - freqüência de divulgação dos serviços (\%/mês)

- Necessidades pessoais - reivindicação da comunidade $(\% /$ mês $)$

Cabe observar que a maioria dos indicadores propostos por CAMPOS (1994) foi definida especificamente para ser aplicada em seu estudo de caso, realizado na cidade de Ribeirão Preto (SP), não estando incluso nos objetivos da sua pesquisa o 
desenvolvimento de indicadores que pudessem ser posteriormente aplicados a outros programas de coleta seletiva.

A contribuição que se pode extrair da pesquisa desse autor refere-se aos critérios adotados para o estabelecimento destes indicadores, que deveriam cumprir as funções de representar as condições dos serviços de coleta seletiva oferecidos e possibilitar a análise sistemática da evolução das condições de atendimento à população. Em suma, o autor buscou determinar o grau de inter-relacionamento entre o serviço de coleta seletiva e seus efeitos no atendimento ao bem-estar da população.

AGUIAR (1999), que realizou seu trabalho junto à Faculdade de Saúde Pública, agrupou os indicadores em quatro dimensões para avaliar alguns programas de coleta seletiva brasileiros:

\section{Dimensão Operacional}

- Quantidades de resíduos coletados ( $\mathrm{t} / \mathrm{mês})$

- Eficiência da mão-de-obra de coleta (t/pessoa.h)

- Eficiência de mão-de-obra de triagem (t/pessoa.h)

- Eficiência de transporte (t/veículo.h)

Dimensão Econômica

- Custo unitário de coleta e triagem $(\mathrm{R} \$ / \mathrm{t})$

- Porcentagem da receita proveniente de cada material vendido

- Preços dos materiais vendidos

- Percepção sobre a viabilidade econômica da atividade

- Investimentos realizados para implantação da coleta e reciclagem

Dimensão Político-institucional

- Iniciativa do programa

- Responsabilidade e contribuição de cada instituição nas parcerias

- Percepção das entidades quanto a sua participação e dos parceiros

- Percepção das entidades quanto a parceria potencia

- Visão do Futuro 


\section{Dimensão Sócio-ambiental}

- Composição percentual de materiais recicláveis vendidos no programa

- Taxa de desvio

- Taxa de recuperação

- Coleta de resíduos per capita

- Presença de artrópodes e roedores de interesse em saúde pública e medidas preventivas tomadas para evitar sua proliferação

AGUIAR (1999) estudou as parcerias em programas de coleta seletiva partindo da premissa de que os mesmos podem ser vistos como uma teia complexa de atores sociais, interagindo e trocando entre si materiais e valores econômicos. O grupo de indicadores adotado foi definido com base no uso de dimensões decorrentes de características identificadas nos programas avaliados para as questões associadas aos resíduos sólidos domésticos e os diversos aspectos envolvidos na sua solução.

Alguns indicadores utilizados pelo autor são de caráter qualitativo, tendo sido levantados através de entrevistas feitas junto aos responsáveis pelos programas de coleta seletiva avaliados.

A questão da avaliação da participação da população ainda é pouco explorada no país. Referência com informações sistematizadas encontradas sobre essa questão é o artigo - Como Mensurar a participação de uma população/comunidade em um Programa de Coleta Seletiva resultante de pesquisa no âmbito de um programa de coleta seletiva desenvolvido dentro de um campus universitário (NUNESMAIA 1995).

NUNESMAIA (1995) utilizou instrumentos de pesquisa qualitativa (opinião da comunidade sobre coleta seletiva) e quantitativa (comportamento da característica física do lixo coletado) associados, para obter resultados:

A autora utilizou como instrumento a opinião da comunidade sobre coleta seletiva levantando:

- o grau de informação do público sobre o programa;

- a opinião dos estudantes sobre a coleta seletiva (se é complicado ou não);

- o instrumento informativo que mais atingiu o público alvo; 
- o grau de interesse despertado;

- o grau de memorização (conhecimento) das cores utilizadas nos coletores de lixo reciclável.

E também como segundo instrumento, o comportamento da característica física do lixo coletado, realizando:

- Análise da composição gravimétrica do total do lixo gerado no local de estudo.

- Análise da composição gravimétrica de cada uma das parcelas de lixo coletado em separado (\%).

- Percentual de materiais recicláveis presentes na parcela de lixo a ser encaminhado ao aterro (\%).

Considerando-se, na presente pesquisa, os programas de coleta seletiva implantados e em funcionamento no país, foram levantados os indicadores utilizados no município de Vitória, estado do Espírito Santo, local escolhido para o estudo de caso da presente pesquisa.

A equipe técnica da Secretaria Municipal de Meio Ambiente e Serviços de Vitória, face ao Projeto Piloto de Coleta Seletiva implantado em 1998, vem realizando o registro sistemático dos seguintes indicadores (BATISTA, 2001):

- $\mathrm{n}^{\mathrm{o}}$ de roteiros coletados

- $\mathrm{n}^{\mathrm{o}}$ de PEVs coletados

- peso total de resíduos coletado (t/mês),

- peso materiais recicláveis (t/mês),

- peso dos materiais impróprios ( $\mathrm{t} / \mathrm{mês})$,

- \% de materiais impróprios,

- quilometragem total percorrida ( $\mathrm{km} / \mathrm{mês})$,

- extensão média por roteiro $(\mathrm{km})$,

- tempo total de coleta (h./mês),

- tempo médio de coleta por roteiro (h),

- receita apurada (vendas) (R\$/mês),

- custo total de coleta (R\$/mês), 
- custo líquido de coleta ( $\mathrm{R} \$ / \mathrm{mês})$,

- custo bruto unitário $(\mathrm{R} \$ / \mathrm{t})$,

- custo líquido unitário $(\mathrm{R} \$ / \mathrm{t})$,

- custo bruto unitário (US\$/t),

- custo líquido unitário (US\$/t),

- custo líquido unitário (US\$/t),

- quantidade média coletada $/ \mathrm{km}$ de coleta $(\mathrm{t} / \mathrm{km})$,

- quantidade média coletada/hora de coleta $(\mathrm{t} / \mathrm{h})$.

Além desses registros, a equipe da prefeitura de Vitória realiza periodicamente análise da composição gravimétrica dos resíduos sólidos e apuração do índice de recuperação de materiais para a reciclagem.

Do questionário SNIS (MC 2003), enviado aos municípios pelo Ministério das Cidades, em 2003, tem-se:

- responsável pela execução da coleta seletiva;

- modalidades de coleta seletiva existentes;

- quantidade anual de materiais recicláveis provenientes da triagem $(\mathrm{t})$;

- $\quad$ presença de catadores no lixão e catadores dispersos na cidade;

- quantidade de catadores existentes (menores de 14 anos/ maiores de 14 anos);

- existência de organização de catadores;

- existência de trabalho social com catadores.

Nesse contexto, realizando-se uma análise geral desses indicadores levantados, observa-se a falta de padronização quanto à nomenclatura atribuída por diferentes estudos e quanto às metodologias de cálculo adotadas. Para o estabelecimento desses indicadores verificam-se que os aspectos de custo e escala relativos à coleta seletiva (quantidades coletadas) são mais freqüentemente adotados pelos autores, seguidos dos indicadores relativos à receita, à cobertura de atendimento populacional do programa, de desempenho da operação da coleta seletiva e da recuperação de materiais para a reciclagem. 
Fatores relacionados ao monitoramento da qualidade dos resíduos coletados, à operação da etapa de triagem e de beneficiamento e ao investimento em educação e marketing, como também à participação da população aparecem em menor escala.

Atribui-se tal cenário ao fato dos indicadores freqüentemente adotados serem também os de mais fácil apuração na prática.

Fazendo um paralelo com os estudos de FRANCA (2001), para indicadores ambientais urbanos, tem-se que o processo decisório sobre o grupo de indicadores apropriados para permitir avaliar o desempenho de programas de coleta seletiva, deve buscar proporcionar elevado grau de agregação e simplicidade de entendimento das informações relevantes.

Ainda com base no autor, tem-se que a sistematização das informações sobre a coleta seletiva de RSU para apresentação na forma de indicadores, requer o uso de estrutura de organização lógica das informações de modo as responder questões como:

- O que está acontecendo com o programa de coleta seletiva implantado?

- Por que tal fato está acontecendo?

- O que está sendo feito a respeito?

Proporcionando, assim, uma base sólida para tomada de decisões em todos níveis referente ao gerenciamento de programas de coleta seletiva de RSU.

E é dentro da perspectiva de se contribuir com o nível de conhecimento atual sobre os aspectos operacionais e de participação social da coleta seletiva de RSU que se apresenta, no Capítulo 3, a formulação do problema estudado na presente tese. 


\section{FORMULAÇÃO DO PROBLEMA}

A disposição inadequada dos resíduos sólidos apresenta-se como fator de risco à saúde pública e ao meio ambiente. Dessa forma, é fundamental que as medidas tomadas para seu gerenciamento sejam bem estudadas e selecionadas e que as alternativas de solução sejam implantadas e operadas adequadamente.

No Brasil, a maioria dos municípios dispõe seus resíduos de forma inadequada. Segundo os dados sobre alternativas de disposição final de resíduos sólidos urbanos nos municípios brasileiros apresentados pela Pesquisa Nacional de Saneamento Básico (IBGE 2002), 21,26\% dos municípios dispõem seus resíduos sólidos em lixões ou áreas alagadas; 37,03\% em aterros controlados; 36,18\% em aterros sanitários; 4,3\% em unidades de compostagem, triagem e incineração e 1,23\% desses não informaram o destino.

A Coleta Seletiva é uma estratégia importante a ser adotada no gerenciamento dos resíduos sólidos urbanos, a qual, embora implementada na etapa de coleta dos resíduos, visa à recuperação desses e à otimização das etapas de tratamento e destinação final, reduzindo impactos sanitários e ambientais.

A maior parte das iniciativas e ações referentes à coleta seletiva existentes no país são informais. Apenas pequena parcela dos municípios brasileiros possuem Programas de Coleta Seletiva implantados e em operação.

Nesses municípios, verificam-se que os enfoques adotados na gestão dos Programas de Coleta Seletiva poderiam ser agrupados em:

1. Coleta Seletiva como Resgate de Cidadania - no qual o foco principal é o aspecto social. Nesse caso, princípios técnicos (ambientais, sanitários, e outros) e econômicos do gerenciamento podem ficar em segundo plano;

2. Coleta Seletiva como Estratégia de Marketing - no qual o foco principal é a divulgação do órgão, empresa ou entidade que está promovendo o programa. Também, nesse caso, princípios técnicos e econômicos do gerenciamento podem ficar em segundo plano; e,

3. Coleta Seletiva como Instrumento de Gerenciamento Integrado de Resíduos esta visão pressupõe o envolvimento da sociedade e a integração da coleta 
seletiva a um sistema mais amplo, onde todos os resíduos são trabalhados de forma integrada.

Na prática, observa-se que a maioria das iniciativas dos Programas de Coleta Seletiva desenvolvidos no país adota os enfoques 1 e 2, o que dificulta, e até pode comprometer, o alcance da sustentabilidade desses programas.

EIGENHEER (1999) verifica que a insuficiência na avaliação sistemática de experiências de coleta seletiva, no Brasil, tem dado margem à perigosa idéia de que a coleta seletiva de lixo seria um bem em si mesma ou até uma panacéia para o setor de resíduos sólidos.

Tal situação tem levado técnicos e pesquisadores do setor a apontar a necessidade de busca de padronização na apresentação de experiências e na definição de indicadores, fundamentais, para comparações e análises que possam subsidiar a implantação de novos programas, o planejamento e a execução de políticas públicas e ações mais adequadas para o setor.

A criteriosa avaliação dos fatores envolvidos no planejamento e na implantação de Programas de Coleta Seletiva contribuem, decisivamente, para que sejam definidas diretrizes adequadas, em especial quanto aos aspectos que interferem no seu custo de implantação e operação e na efetiva adesão da população ao programa.

O planejamento poderia ser utilizado como ferramenta para a implantação, ampliação e/ou modernização de programas de coleta seletiva, garantindo otimização de investimentos e custos operacionais reduzidos. Entretanto, a carência de informações confiáveis sobre os indicadores de coleta seletiva, algumas vezes, impede ou dificulta que este planejamento seja realizado de modo adequado.

As pesquisas realizadas no país sobre o tema, geralmente, têm se concentrado nos aspectos operacionais da questão, não aprofundando a análise quanto aos aspectos de participação da população.

Uma das principais dificuldades encontradas ao se planejar a implantação de um Programa de Coleta Seletiva refere-se à definição de parâmetro relativo à expectativa da participação da população, sendo que dele decorre o tamanho do investimento a ser realizado. 
Este parâmetro depende, basicamente, do perfil sócio-econômico e cultural da população, da eficiência da estratégia de marketing adotada para sensibilização e motivação das pessoas a participarem, da adequação do projeto à realidade local e da regularidade no funcionamento da logística implantada para dar suporte ao sistema.

A partir da observação dos dados levantados durante a etapa piloto do Programa de Coleta Seletiva, implantado no município de Vitória, e da revisão de literatura sobre a participação da população, foi possível apresentar a proposta de se agrupar a população alvo da coleta seletiva em três grupos distintos:

- Grupo Cativo - formado por uma parcela da população que, na medida em que exista infra-estrutura mínima de funcionamento da coleta seletiva, participa efetivamente, independente de estímulos externos, pois já internalizou tais conceitos como cidadão;

- Grupo de Participação Eventual - formado pela parcela da população que participa eventualmente da coleta seletiva, em função de estratégias de marketing adotadas pelos programas implementados; e,

- Grupo que não Participa - formado pela parcela da população que não participa por filosofia própria, em nenhuma iniciativa do poder público e/ou que não acredita na efetividade de tais iniciativas, ou não pode participar, pelos motivos os mais diversos.

A partir da análise das informações e dados levantados na revisão de literatura, foi constatado que:

$\Rightarrow$ no Brasil, os Programas de Coleta Seletiva de RSU em geral carecem de registro sistemático de informações, na forma de indicadores;

$\Rightarrow$ existe um ponto de saturação dos Programas de Coleta Seletiva, o qual não permite que a capacidade de recuperação de materiais recicláveis cresça proporcionalmente aos investimentos econômicos, técnicos, sociais e em educação efetuados; e,

$\Rightarrow$ há grande dificuldade de se avaliar a expectativa da participação da população, durante a etapa de planejamento de um Programa de Coleta Seletiva, o que leva a 
ser sobrestimada tal participação, resultando na insuficiência das ações de mobilização da comunidade.

Nesse contexto, são admitidas duas hipóteses para a presente pesquisa:

\section{Hipótese 1:}

É possível representar os diversos aspectos operacionais envolvidos em Programas de Coleta Seletiva a partir de um grupo de indicadores.

\section{Hipótese 2:}

O tipo de participação social é fator de maior ou menor sucesso dos programas de coleta seletiva, havendo diferentes respostas da população em relação à participação que podem ser agrupadas em: grupo cativo, de participação eventual e que não participa.

Para investigação da Hipótese 1, foi utilizado um grupo de indicadores de referência para o monitoramento e controle de Programas de Coleta Seletiva, grupo esse instituído no âmbito da presente pesquisa, resultante de levantamento dos mais diferentes indicadores utilizados em Programas de Coleta Seletiva no país e associado ao estudo de caso para o município de Vitória.

Para a Hipótese 2, foi realizada pesquisa de campo, utilizando-se métodos qualitativos para conhecer a percepção coletiva, de diferentes grupos populacionais do município de Vitória, sobre a questão da coleta seletiva de resíduos sólidos urbanos.

No Capítulo 4, a seguir, são apresentados os objetivos traçados para o desenvolvimento da presente tese. 


\section{OBJETIVOS}

\subsection{Objetivo Geral}

Avaliar aspectos operacionais e da participação da população em Programas de Coleta Seletiva de resíduos sólidos urbanos, tendo como estudo de caso o município de Vitória-ES, com a finalidade de:

1. instituir grupo de indicadores de referência para o planejamento e a avaliação de desempenho de Programas de Coleta Seletiva;

2. identificar fatores de motivação da população quanto à participação em Programas de Coleta Seletiva;

3. propor diretrizes para subsidiar políticas públicas em Programas de Coleta Seletiva.

\subsection{Objetivos Específicos}

1. identificar os principais indicadores utilizados para o planejamento e a avaliação de desempenho em Programas de Coleta Seletiva de resíduos sólidos urbanos no Brasil;

2. validar grupo de indicadores de referência para Programas de Seletiva de resíduos sólidos urbanos e aplicar, a esses indicadores, a série histórica de dados do município de Vitória-ES;

3. identificar os pontos críticos dos Programas de Coleta Seletiva implantados no município de Vitória-ES;

4. levantar aspectos que impedem e/ou dificultam a participação da população nos Programas de Coleta Seletiva implantados no município de Vitória-ES;

5. levantar o nível de informações do pessoal, direta e indiretamente, envolvido com a implementação dos Programas de Coleta Seletiva do município de Vitória - ES.

A seguir, é apresentada, no Capítulo 5, a metodologia adotada para o desenvolvimento dos estudos necessários ao atendimento dos objetivos traçados. 


\section{METODOLOGIA}

Esta pesquisa teve origem na observação, por parte da pesquisadora, da ocorrência de problemas semelhantes em diversos programas de coleta seletiva de resíduos sólidos urbanos de cidades brasileiras, que contribuíam para a sua falta de sustentabilidade e/ou descontinuidade.

No Capítulo 3, foram apresentadas, duas hipóteses para o desenvolvimento da presente tese. Essas hipóteses foram testadas, mediante estudo descritivo, pesquisa de caráter exploratória, que, segundo GIL (1996), têm como objetivo a descrição de determinada população ou fenômeno, estabelecendo relações entre variáveis, sendo o caráter exploratório decorrência do desenvolvimento de uma nova visão do problema.

Ao longo da pesquisa, foram desenvolvidas diversas etapas metodológicas, visando conhecer os mais variados aspectos do problema formulado. Desde entrevistas com profissionais que possuem conhecimento em programas de coleta seletiva de resíduos sólidos urbanos e com a população envolvida, até o tratamento estatístico dos dados obtidos e a aplicação dos resultados encontrados em um estudo de caso.

Enfim, buscou-se gerar produtos para subsidiar a melhoria do gerenciamento de programas de coleta seletiva e políticas públicas relativas ao tema.

\subsection{Objeto de Estudo}

Adotou-se como objeto de estudo os programas de coleta seletiva de resíduos sólidos urbanos desenvolvidos no Brasil, sendo que o município de Vitória, capital do Estado do Espírito Santo, foi a base do estudo de caso ora desenvolvido.

Em Vitória, já existiam programas pilotos de coleta seletiva em funcionamento contínuo desde 1998 e a administração municipal iniciou a etapa de ampliação e modernização deste serviço a partir de setembro de 2002.

$\mathrm{Na}$ pesquisa foram avaliados os Programas de Coleta Seletiva do município de Vitória, sob os aspectos operacionais e da participação da população, abordando as modalidades: Coleta Seletiva por Postos de Entrega Voluntária, também, denominada Coleta Seletiva por PEVs; Coleta Seletiva porta a porta; e Coleta 
Seletiva por Trabalhadores Autônomos da Reciclagem, também, denominada Coleta Seletiva Autônoma.

\subsection{Levantamento de Dados}

Foram utilizados instrumentos de pesquisa quantitativos associados a instrumentos qualitativos para a coleta dos dados, que foram a base da análise e discussão desenvolvida, obtendo-se, ao mesmo tempo, informações de caráter técnicogerencial e a percepção da população em relação aos Programas de Coleta Seletiva estudados.

Como etapa inicial, foram realizadas visitas técnicas a algumas experiências municipais brasileiras sobre coleta seletiva de resíduos sólidos urbanos, que resultaram em um cenário, atual, sobre coleta seletiva no país.

As informações colhidas nas visitas técnicas foram associadas aos dados da revisão bibliográfica como base para a definição e a formulação dos instrumentos de pesquisa.

A pesquisa foi desenvolvida em duas etapas metodológicas que, para melhor organização e desenvolvimento da pesquisa, foram subdivididas em fases, apresentadas no Quadro 5.

Na etapa de pesquisa sobre indicadores operacionais buscou-se investigar a Hipótese 1 e na etapa sobre a participação a Hipótese 2.

A partir da definição do grupo de indicadores de referência para programas de coleta seletiva (Fase 1), foram utilizadas as informações resultantes dos programas implantados no município de Vitória como fonte de dados (Fase 2).

Na definição da amostragem para pesquisa de campo, relativas à Fase 3, foram consideradas as características do Programa de Coleta Seletiva do município de Vitória.

As fases 4 e 5 foram desenvolvidas para buscar informações de caráter complementar. 
Quadro 5 - Etapas metodológicas de desenvolvimento da pesquisa. Vitória, 2003

\begin{tabular}{|c|c|c|c|c|}
\hline Etapa & Fases & \begin{tabular}{|c|} 
Tipo de \\
levantamento \\
\end{tabular} & Descrição da atividade & $\begin{array}{c}\text { Período } \\
\text { Realização } \\
\end{array}$ \\
\hline \multirow{2}{*}{$\begin{array}{c}\text { Pesquisa } \\
\text { sobre } \\
\text { Indicadores } \\
\text { Operacionais }\end{array}$} & Fase 1 & Quantitativo & $\begin{array}{l}\text { Estabelecimento de Grupo de } \\
\text { Indicadores } \\
\quad \text { Pesquisa com metodologia } \\
\text { científica e amostragem estatística } \\
\end{array}$ & $\begin{array}{l}\text { Outubro/2002 } \\
\text { a abril/2003 }\end{array}$ \\
\hline & Fase 2 & Quantitativo & $\begin{array}{l}\text { Estudo da série histórica de dados } \\
\text { sobre coleta seletiva a partir do } \\
\text { Grupo de Indicadores } \\
\text { estabelecidos } \\
\text { Pesquisa com metodologia } \\
\text { científica e amostragem estatística }\end{array}$ & $\begin{array}{c}\text { Janeiro/2001 a } \\
\text { maio/2003 }\end{array}$ \\
\hline \multirow{3}{*}{$\begin{array}{l}\text { Pesquisa } \\
\text { sobre } \\
\text { Participação } \\
\text { Social }\end{array}$} & Fase 3 & Qualitativo & $\begin{array}{l}\text { Método de Análise do Discurso do } \\
\text { Sujeito Coletivo } \\
\text { Pesquisa com metodologia } \\
\text { científica e amostragem estatística }\end{array}$ & $\begin{array}{c}1^{\text {a }} \text { etapa - } \\
\text { julho a } \\
\text { agosto/2002 } \\
2^{\text {a etapa - }} \\
\text { maio/2003 } \\
\end{array}$ \\
\hline & Fase 4 & Quantitativo & $\begin{array}{l}\text { Pesquisa realizada via site da } \\
\text { Prefeitura Municipal de Vitória }\end{array}$ & $\begin{array}{c}\text { Agosto a } \\
\text { novembro/ } \\
2002 \\
\end{array}$ \\
\hline & Fase 5 & Quantitativo & $\begin{array}{l}\text { Questionário aplicado aos } \\
\text { funcionários da prefeitura e das } \\
\text { empresas contratadas }\end{array}$ & \begin{tabular}{|c} 
Setembro a \\
outubro/ 2002
\end{tabular} \\
\hline
\end{tabular}

Inicialmente, o plano de ampliação e modernização da coleta seletiva de Vitória previa a expansão do serviço para diversas regiões da cidade para as modalidades: Porta a Porta, Trabalhadores Autônomos da Reciclagem (coleta seletiva autônoma) e Postos de Entrega Voluntária. Na prática, a ampliação da coleta seletiva, segundo a modalidade Trabalhadores Autônomos da Reciclagem (coleta seletiva autônoma) não ocorreu até o mês de maio de 2003, data final do levantamento de dados de campo da presente pesquisa, o que inviabilizou a coleta de dados necessária para estudo mais aprofundado. Assim, na etapa final da pesquisa, optou-se por concentrar o estudo nas modalidades Coleta Seletiva Porta a Porta e por meio de Postos de Entrega Voluntária.

Durante a fase de coleta de dados, além das etapas descritas, foram realizadas observações sistemáticas de campo com anotação de pontos críticos referentes à 
operacionalização dos programas de coleta seletiva e registro fotográfico dos aspectos relevantes.

\subsubsection{Instrumentos de Pesquisa}

A seguir são apresentados os instrumentos de pesquisa utilizados para a realização das etapas metodológicas de desenvolvimento da presente pesquisa.

\subsubsection{Pesquisa sobre Indicadores Operacionais}

Inicialmente, realizou-se busca bibliográfica relativa aos indicadores de coleta seletiva utilizados nos diversos programas de coleta seletiva existentes no país, bem como por instituições de referência que trabalham com o tema, o que resultou em listagem com vinte e cinco indicadores.

Neste ensejo, foram realizadas visitas técnicas aos municípios de São Bernardo do Campo - SP, Santo André - SP, Florianópolis - SC e Porto Alegre - RS, municípios esses que possuem Programas de Coleta Seletiva Municipal implantados e operando há algum tempo, para conhecimento de seus aspectos operacionais e da participação da população.

O objetivo maior dessa etapa quantitativa da pesquisa foi estabelecer um grupo de indicadores de referência em coleta seletiva (Fase 1), de fácil entendimento e aplicação prática, e aplicar os mesmos junto aos Programas de Coleta Seletiva implantados no município de Vitória (Fase 2).

Com base na orientação de profissional de estatística, partiu-se para a etapa de validação de grupo de indicadores, dentre os vinte e cinco identificados, que fosse mais representativo, utilizando-se de métodos estatísticos. Para tanto foram utilizados instrumentos de pesquisa quantitativa, associado a diversas técnicas de tratamento estatístico dos dados, conforme apresentado a seguir:

- Análise Descritiva - partindo-se do levantamento dos indicadores utilizados nos diversos programas de coleta seletiva implantados no país, foram selecionados vinte e cinco indicadores mais representativos desse rol. Os vinte e cinco indicadores, com suas respectivas unidades de medida, compuseram um formulário, no qual deveria ser atribuída nota, numa escala de 1 a 10 , a cada um desses 
indicadores, como forma de se avaliar sua importância. O formulário deveria ser preenchido por profissionais e especialistas, de diversas partes do país, que atuam, direta ou indiretamente, com a questão da coleta seletiva de resíduos sólidos urbanos. Antes da aplicação do formulário pelos especialistas foi realizado pré-teste, para avaliar sua adequação. O questionário utilizado no pré-teste, os resultados do préteste e a versão final do questionário Pesquisa sobre Indicadores de Coleta Seletiva de Lixo, encontram-se no Anexo 2.

A partir do resultado do pré-teste e após ajustes finais, o instrumento foi repassado a cerca de cem profissionais e entidades, principalmente através da internet e por meio de contatos pessoais.

Como retorno da consulta, obteve-se a resposta de cinqüenta e sete formulários, oriundos de diversas partes do país e de entidades públicas e privadas, sendo que a maioria dos especialistas participantes possuía mestrado e experiência relacionada à coleta seletiva superior a dois anos.

Para essa amostra foi realizada análise descritiva dos dados, sendo utilizado o programa estatístico Statistical Package for the Social Sciences, SPSS (2003), versão 8.0.

- Análise Multivariada Fatorial - partindo-se dos resultados da análise descritiva, onde foi avaliado o grau de importância de cada indicador, esses foram agrupados em fatores para se chegar às suas dimensões.

Em seguida foi realizada a Análise Multivariada Fatorial, com auxílio do aplicativo SPSS, versão 8.0, com o objetivo de agrupar variáveis que apresentassem padrão de correlação dentro do conjunto analisado.

Após esse tratamento, que reflete a avaliação dos profissionais, foi obtido o perfil do grupo de indicadores a ser estabelecido. Este grupo obtido, ainda, não representava os indicadores de referência para o planejamento e a avaliação de desempenho de Programas de Coleta Seletiva, sendo necessário efetuar, também, análise qualitativa, realizada a partir da Técnica Delphi; 
- Técnica Delphi - foi utilizada com o objetivo de incorporar a experiência da equipe técnica da prefeitura de Vitória quanto à coleta seletiva, para a avaliação qualitativa do grupo de vinte e cinco indicadores inicialmente selecionados.

Na técnica Delphi um grupo de especialistas, cujas opiniões se deseja considerar, é consultado a respeito de determinado evento até que se obtenha convergência nas respostas (MASSUKATO e ZANTA 2004).

Assim, testou-se o grupo de indicadores em análise por critérios de qualidade, utilizando a experiência dos profissionais do município de Vitória. Para balizar o trabalho dos profissionais, adotou-se os critérios propostos por PEREIRA (1995).

Para aplicação da técnica Delphi, elaborou-se um segundo formulário (Anexo 3), apresentando os mesmos vinte e cinco indicadores com suas respectivas definições e unidades de medida, apresentados na mesma ordem do formulário anterior, aos quais deveriam ser atribuídas notas variando de 1 a 10, nos quesitos abaixo:

- Validade - refere-se à adequação do indicador para medir ou representar, sinteticamente, o fenômeno estudado;

- Confiabilidade (reprodutibilidade ou fidedignidade) - refere-se à garantia de obtenção de resultados semelhantes, quando a mensuração é repetida;

- Representatividade (cobertura) - refere-se à cobertura alcançada pelo indicador em relação ao evento ou fenômeno estudado; e,

- Oportunidade, simplicidade, facilidade de obtenção e custo compatível - referese ao fato de que a obtenção dos dados deve causar o mínimo de perturbação ou inconvenientes, ou seja, não deve interferir nas condições habituais de funcionamento dos serviços, além de ter custos compatíveis.

Na técnica Delphi são realizadas rodadas sucessivas de preenchimento do formulário, até se chegar a um consenso. Nesse caso, a técnica foi aplicada a sete profissionais, sendo necessário realizar duas rodadas, nas quais os profissionais foram reunidos para apresentação dos formulários e critérios de preenchimento. Estes profissionais compõem o grupo de técnicos da prefeitura de Vitória envolvidos com o gerenciamento do programa de coleta seletiva e já haviam respondido ao primeiro questionário (Análise Descritiva e Análise Multivariada Fatorial). 
Na primeira rodada, após uma explanação ao grupo sobre o objetivo da pesquisa, cada participante respondeu ao questionário individualmente.

Após tabulação dos resultados da primeira rodada, utilizando-se o programa estatístico SPSS versão 8.0, verificou-se que as notas atribuídas pelos profissionais para nove dos vinte e cinco indicadores apresentavam grande variabilidade (desvio padrão).

Para a segunda rodada, como se buscava o consenso, discutiu-se, em conjunto com os profissionais, cada um dos nove indicadores com avaliação discrepante e, em seguida, o questionário foi, novamente, respondido individualmente.

A conjugação de técnicas estatísticas foi adotada para validar o grupo de indicadores por entender que a análise descritiva não seria suficiente para embasar o desenvolvimento da pesquisa.

A partir da avaliação conjunta dos resultados das três técnicas empregadas, foi obtido grupo de indicadores de referência para o planejamento e a avaliação de desempenho de Programas de Coleta Seletiva.

O grupo de indicadores definido foi aplicado aos dados resultantes do programa de coleta seletiva do município de Vitória (Fase 2), como estudo de caso, permitindo verificar a hipótese 1.

Paralelamente à atividade de identificação do grupo de indicadores de referência e aplicação desses ao programa de coleta seletiva, foi realizado diagnóstico da situação dos diferentes tipos de coleta seletiva empregados no município de Vitória.

A coleta de dados, junto à Prefeitura, foi realizada de modo a não interferir nos procedimentos de rotina do Sistema de Limpeza Urbana, sendo que somente foi possível obter dados consistentes relativos ao período de 2001 a 2003, os quais integram essa pesquisa.

\subsubsection{Pesquisa sobre a Participação Social}

Os aspectos da participação da população nos programas de coleta seletiva (Fase 3) foram levantados mediante pesquisa qualitativa, considerada adequada para conhecer a percepção e a motivação das pessoas em participar desses programas. 
Paralelamente à pesquisa qualitativa, como informação complementar, realizou-se também dois levantamentos quantitativos: o primeiro voltado para o público que acessa o site da Prefeitura Municipal de Vitória (Fase 4); e o segundo para o pessoal interno à Prefeitura e empresas contratadas pela municipalidade para fornecer serviços relativos à limpeza urbana (Fase 5), visando conhecer aspectos da participação deste público que atua, direta e indiretamente, no Planejamento e na Gestão do Programa de Coleta Seletiva do município de Vitória.

\section{I - Pesquisa Qualitativa - Participação da População na Coleta Seletiva}

Fase 3 - Análise do Discurso do Sujeito Coletivo

Para o conhecimento dos aspectos da participação da população alvo do programa e o significado que as pessoas dão, em seu cotidiano, à coleta seletiva, buscou-se analisar, comparativamente, as expectativas e a efetiva participação da população dos bairros contemplados com esse serviço, face ao referido programa, através de instrumentos de pesquisa qualitativa. Para tanto, foi empregada a técnica do Discurso do Sujeito Coletivo desenvolvida por LEFÉVRE e LEFÉVRE (2002), definido pelos autores como: O Discurso do Sujeito Coletivo é uma coletividade falando como se fosse um indivíduo.

Esta metodologia parte do pressuposto que as pessoas pensam através de discursos e que é metodologicamente possível expressar o pensamento coletivo sob a forma de discursos coletivos, denominados Discurso do Sujeito Coletivo (DSC). Trata-se de um discurso síntese, elaborado na primeira pessoa do singular, a partir dos dados obtidos nos depoimentos dos entrevistados.

A pesquisa qualitativa foi planejada ao longo do primeiro semestre de 2002 e com base nas informações disponibilizadas pela prefeitura de Vitória, optou-se pela aplicação do instrumento de pesquisa qualitativa seis meses antes e seis meses após a implementação da etapa de ampliação dos Programas de Coleta Seletiva na cidade. A amostragem foi realizada por sorteio, considerando-se a classe social e as modalidades de coleta seletiva implantadas. 
Para definição da amostra populacional a ser pesquisada, inicialmente foram analisadas informações disponíveis sobre o município de Vitória e que poderiam ser consideradas na amostragem estatística, sendo as mais representativas:

- os dados do IBGE sobre população e número de domicílios, segundo bairros;

- a divisão do município em sete regiões administrativas, que agrupam bairros com características semelhantes e representa a unidade de planejamento e gerenciamento da prefeitura;

- a classificação sócio-econômica dos bairros, em função da renda média da população residente, elaborado pela prefeitura, com base nos dados do Censo do IBGE de 1996;

- as informações disponibilizadas pela prefeitura, relativas à etapa piloto do programa de coleta seletiva, implantada em alguns bairros desde 1998; e,

- o planejamento da prefeitura para ampliação do programa de coleta seletiva no período de 2002 a 2005, segundo bairros e regiões administrativas a serem contemplados.

A partir da análise das informações colhidas, adotou-se os seguintes pressupostos com fim de facilitar a aplicação futura dos resultados da pesquisa:

1. adotar o bairro como unidade de trabalho, uma vez que as modalidades de coleta seletiva seriam implantadas por bairros;

2. adotar a classificação de bairros da prefeitura segundo classe social, uma vez que o aspecto sócio-econômico é fator determinante na análise das expectativas e na efetiva participação da população em programas de coleta seletiva de resíduos sólidos urbanos (SEMMAM 2002); e,

3. realizar o processo de amostragem em três etapas, considerando as peculiaridades de cada uma das modalidade de coleta seletiva (estratificação), uma vez que as diferentes modalidades não seriam implantadas em todos os bairros do município em 2002.

Cabe registrar, que as informações consideradas na estratificação dos bairros foram obtidas da Prefeitura Municipal de Vitória, até abril de 2002, por meio de contato pessoal*. 
A partir de tais pressupostos, iniciou-se propriamente o processo de amostragem.

Adotando-se a classificação elaborada pela prefeitura de Vitória, foi confeccionado um mapa temático, com a divisão da cidade em bairros, diferenciando por cores os bairros que apresentavam diferentes classes sociais em seu território.

A classificação sócio-econômica dos bairros adotada pela prefeitura, em função da renda média da população residente medida em salários mínimos (s.m.), com base nos dados do Censo do IBGE de 1996 é:

classe social D: até 2,0 s.m;

classe social C: de 2,0 a 5,0 s.m;

classe social B: de 5,0 a 10 s.m; e,

classe social A: maior que 10,0 s.m.

No mesmo mapa temático, foram delimitados os bairros e regiões atendidas até dezembro de 2001, pela etapa piloto e também os bairros a serem contemplados em 2002, mediante a ampliação da coleta seletiva no município. Utilizou-se o tracejado em azul para delimitar as regiões atendidas com a coleta seletiva porta a porta e o tracejado em vermelho para as regiões contempladas com a coleta seletiva autônoma. A coleta seletiva por PEVs foi implantada em todas as regiões administrativas do município a partir da ampliação do programa.

A Figura 5 apresenta o mapa temático com a classificação sócio econômica e população dos bairros de Vitória, o qual permite ter uma visão espacial da distribuição das diferentes modalidades de coleta seletiva no município.

* Informações obtidas em abril de2002, através de contato pessoal, com o gerente do Programa Vitória Reduz e Recicla, o Eng. Carlos Roberto de Lima. 


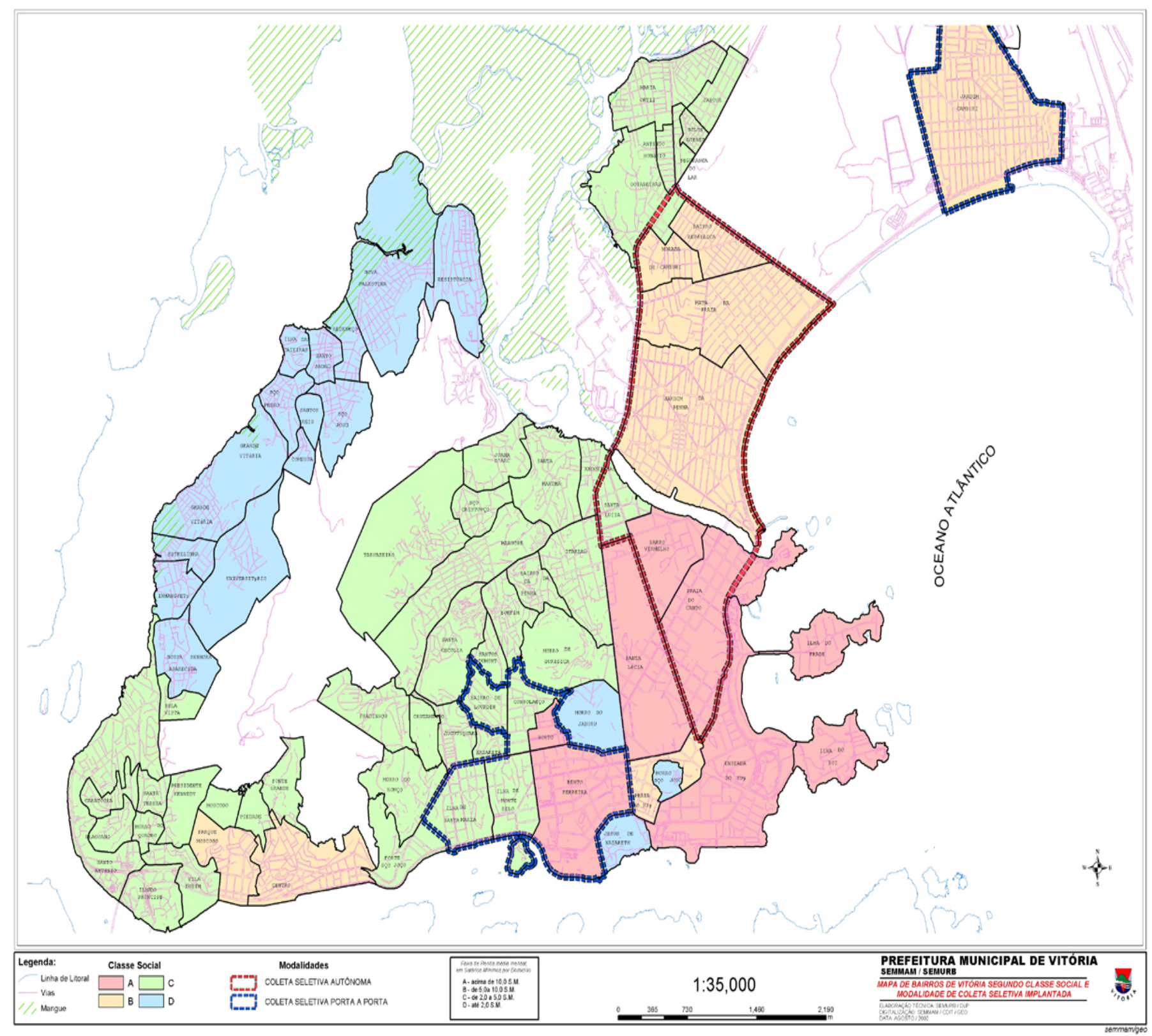

Figura 5 - Distribuição espacial das modalidades de coleta seletiva implantadas no município de Vitória, segundo classe social. 2002

\section{Legenda:}

Classe Social - Cor: Classe A - rosa Classe B - laranja Classe C - verde Classe D - azul Modalidade: tracejado azul - coleta seletiva porta a porta; tracejado vermelho - coleta seletiva autônoma 
De posse de tais informações, procedeu-se à amostragem aleatória dos bairros, segundo modalidade de coleta seletiva. Ao longo do processo de amostragem foi-se desconsiderando, nas etapas subseqüentes de sorteio, os bairros já sorteados anteriormente, uma vez que o questionário a ser aplicado seria o mesmo para todas as modalidades de coleta seletiva.

Para fins do sorteio, trabalhou-se com um universo total de 73 bairros, considerandose a estratificação, segundo as modalidades de coleta seletiva já implementadas ou a serem implementadas na ampliação do programa.

As estratificações com as respectivas amostras, são apresentadas a seguir:

\section{a) Coleta Seletiva Porta a Porta}

Esta modalidade de coleta seletiva não existia no município e foi implementada, a partir de agosto de 2002, em 7 bairros envolvendo duas regiões administrativas.

Os bairros a serem beneficiados com a coleta seletiva porta a porta estão descritos a seguir, segundo classe social:

Bairros classe A: Bento Ferreira e Horto;

Bairros classe B: Jardim Camburi;

Bairros classe C: Bairro de Lourdes, Bairro Consolação, Ilha de Santa Maria e Ilha de Monte Belo; e,

Bairros classe D: não incluídos no programa de coleta seletiva municipal para esta modalidade.

O sorteio dos bairros que comporiam a amostra foi realizado agrupando-se os bairros acima listados em classes sociais A ou B e em classe C ou D.

Para fins do sorteio do grupo de classe A ou B, desconsiderou-se o bairro Horto por ser pouco representativo em termos populacionais.

Os bairros sorteados foram:

Classe A ou B : Jardim Camburi; $e$,

Classe C ou D: Ilha de Monte Belo.

\section{b) Coleta Seletiva por Trabalhadores Autônomos da Reciclagem}


Esta modalidade estava implantada no município desde 1999, a partir da etapa piloto do programa de coleta seletiva de resíduos sólidos urbanos de Vitória. O galpão de triagem de materiais recicláveis situa-se em um bairro e a área de ação dos catadores com carrinhos padronizados, operados com tração humana, abrange outros oito bairros, a saber:

Bairros Classe A: Barro Vermelho, Praia do Canto e Santa Lúcia.

Bairros Classe B: Bairro República (sede do galpão), Mata da Praia, Jardim da Penha e Morada de Camburi.

Bairros Classe C: Santa Luzia e Goiabeiras (parte).

Bairros Classe D: não incluídos no programa de coleta seletiva da prefeitura para esta modalidade.

Considerando-se as informações disponibilizadas pela prefeitura até abril de 2002, observou-se que a etapa de ampliação da coleta seletiva autônoma deveria ser implementada nos bairros a serem contemplados com a coleta seletiva porta a porta. Partindo-se do universo de 14 bairros, sendo nove bairros dentre os atendidos com a coleta seletiva autônoma e cinco dentre os bairros a serem beneficiados com a coleta seletiva porta a porta, desconsiderando os bairros de Jardim Camburi e Ilha de Monte Belo já sorteados, procedeu-se ao sorteio, agrupando-se os bairros em classe A ou B e em classe C ou D.

Para fins do sorteio do grupo de Classe A ou B, novamente foi desconsiderado o bairro Horto por ser pouco representativo da Classe.

Os Bairros sorteados foram:

Classe A ou B: Mata da Praia; e,

Classe C ou D: Bairro de Lourdes.

\section{c) Coleta Seletiva por Postos de Entrega Voluntária}

No momento do sorteio, esta modalidade de coleta seletiva estava implantada em alguns bairros da cidade e seria ampliada, a partir do segundo semestre de 2002, para todos os bairros da cidade. Assim sendo, desconsiderou-se os 4 bairros já sorteados e agrupou-se todos os demais em Classe A ou B, num total de 14 bairros e em Classe C ou D, num total de 55 bairros. 
Os bairros sorteados foram:

Classe A ou B: Praia do Suá; e,

Classe C ou D: Jucutuquara.

Dentre os bairros sorteados para a modalidade PEV, observou-se que na Praia do Suá foi implantada a coleta seletiva em 1998 e posteriormente desativada por problemas operacionais e baixa participação populacional. O bairro de Jucutuquara ainda não havia sido contemplado com o programa.

O Quadro 6 apresenta os bairros sorteados, para aplicação do instrumento de pesquisa qualitativa, segundo classe sócio-econômica e modalidade de coleta seletiva na qual foram sorteados:

Quadro 6 - Bairros sorteados para aplicação da primeira etapa da pesquisa qualitativa, segundo classe sócio-econômica e estratificação por modalidade da coleta seletiva.

\begin{tabular}{|c|l|l|}
\hline $\begin{array}{c}\text { Classe sócio- } \\
\text { econômica }\end{array}$ & $\begin{array}{c}\text { Bairros sorteados } \\
\text { para Pesquisa }\end{array}$ & $\begin{array}{c}\text { Modalidade de Coleta Seletiva } \\
\text { (estratificação) }\end{array}$ \\
\hline A & Mata da Praia & coleta seletiva autônoma (b) \\
\hline \multirow{2}{*}{ B } & Jardim Camburi & coleta seletiva porta a porta (a) \\
\cline { 2 - 3 } & Praia do Suá & coleta seletiva por PEVs (c) \\
\hline \multirow{2}{*}{ C } & Jucutuquara & coleta seletiva por PEVs (c) \\
\cline { 2 - 3 } & Ilha de Monte Belo & coleta seletiva porta a porta (a) \\
\cline { 2 - 3 } & Bairro de Lourdes & coleta seletiva autônoma (b) \\
\hline \multirow{2}{*}{ D } & - & \\
\hline
\end{tabular}

Dentre os bairros sorteados, de acordo com o planejamento da Prefeitura, todos seriam contemplados com a coleta seletiva por PEVs, sendo que o bairro de Jucutuquara teria, exclusivamente, esta modalidade e os demais estariam atendidos com pelo menos duas modalidades de coleta seletiva.

Inicialmente, planejou-se aplicar 6 questionários, considerando-se diferentes categorias de indivíduos, representativa do bairro pesquisado:

- 1 líder comunitário ou representante político local; 
- 1 morador entre 20 e 59 anos, sexo feminino;

- 1 morador entre 20 e 59 anos, sexo masculino;

- 1 morador com 60 anos ou mais, sexo masculino;

- 1 morador com 60 anos ou mais, sexo feminino; e,

- 1 comerciante ou 1 industrial.

Após definição do instrumento de coleta de dados, foi realizado um pré-teste no bairro Jardim da Penha, bairro não selecionado na amostra. O questionário utilizado no pré-teste e os seus resultados encontram-se no Anexo 4.

Com base nos resultados do pré-teste do instrumento de pesquisa qualitativa definiuse que, em cada um dos bairros sorteados, seriam realizadas 8 entrevistas, seguindo a amostra intencional:

- 1 líder comunitário ou representante político local;

- 1 morador entre 16 e 30 anos, sexo feminino;

- 1 morador entre 16 e 30 anos, sexo masculino;

- 1 morador entre 30 e 59 anos, sexo feminino;

- 1 morador entre 30 e 59 anos, sexo masculino;

- 1 morador com 60 anos ou mais, sexo masculino;

- 1 morador com 60 anos ou mais, sexo feminino; e,

- 1 comerciante ou industrial.

Essa amostra intencional foi definida por alguns critérios que visavam inserir:

$\checkmark$ pessoas com idade que já podem votar e ser votado em eleições de representantes políticos e, portanto, interferir nas decisões sobre políticas públicas;

$\checkmark$ o grupo representativo das pessoas que assumem a administração da residência, como as donas de casa, que geralmente são responsáveis pelo gerenciamento dos resíduos sólidos no núcleo familiar;

$\checkmark$ o grupo representativo dos chefes de família, que provém o sustento da casa;

$\checkmark$ o grupo dos formadores de opinião local; e,

$\checkmark$ o grupo dos aposentados, que são potenciais parceiros de programas desta natureza, pela maior disponibilidade de tempo. 
Para atender aos requisitos do método de pesquisa qualitativa adotado, as entrevistas foram feitas por entrevistadores capacitados para esse fim, que desconheciam a problemática ora estudada, sem a presença do autor da presente pesquisa, sendo todas as entrevistas gravadas em meio magnético e, após, transcritas para análise.

\section{Realização das Entrevistas para Pesquisa Qualitativa}

$1^{\text {a }}$ etapa da pesquisa de campo - antes da ampliação dos Programas de Coleta Seletiva

A primeira etapa de levantamento de dados qualitativos em campo, realizada antes da implantação, por parte da prefeitura, da etapa de ampliação da coleta seletiva, totalizou 48 entrevistas, sendo 8 entrevistas por bairro selecionado, aplicadas à amostra intencional adotada. As entrevistas foram realizadas por 3 entrevistadores, no período de 12 de julho a 3 de agosto de 2002. Todos os representantes dos estratos definidos na amostra foram abordados aleatoriamente, exceto o líder comunitário que foi contatado previamente via telefone.

Na primeira etapa da pesquisa qualitativa trabalhou-se com dois roteiros de pesquisa, sendo o primeiro (roteiro I) para os bairros onde já existia coleta seletiva e o segundo (roteiro II) para os demais. Os roteiros de pesquisa de campo I e II, a ficha de controle e o termo de consentimento encontram-se no anexo 4.

\section{$2^{\mathrm{a}}$ etapa da pesquisa de campo - após ampliação dos Programas de Coleta}

\section{Seletiva}

A segunda etapa de pesquisa de campo, realizada após a implantação, por parte da prefeitura, da etapa de ampliação da coleta seletiva, aconteceu no período de 10 a 21 de maio de 2003, sendo as entrevistas realizadas por outra entrevistadora que não participou da primeira etapa.

Como na segunda etapa da pesquisa todos os bairros já haviam implantado a coleta seletiva foi aplicado somente o roteiro I para todos os bairros.

Com base nos resultados da primeira etapa da pesquisa de campo, bem como no estágio de desenvolvimento dos Programas de Coleta Seletiva, foram realizadas algumas alterações no questionário inicialmente aplicado, visando otimizar a realização da $2^{\mathrm{a}}$ etapa da pesquisa. 
A análise dos resultados da $1^{\mathrm{a}}$ etapa da pesquisa qualitativa demonstrou que a maioria das pessoas entrevistadas não tinha conhecimento do conceito de coleta seletiva, confundindo-a com a coleta regular municipal e consideravam a separação para a coleta seletiva como a própria reciclagem e não como a primeira etapa desta. Assim, houve uma pequena alteração na segunda pergunta do roteiro a qual passou a ser.

\section{Você já ouviu falar de Coleta Seletiva e de reciclagem do lixo? Fale um pouco sobre isso.}

Ao invés de

\section{Você já ouviu falar de Coleta Seletiva? Fale um pouco sobre isso.}

Por outro lado, o planejamento inicial da amostragem foi baseado nas informações disponibilizadas pela prefeitura até abril de 2002, quando a coleta seletiva autônoma deveria ter sido ampliada para uma das regiões a serem contempladas com a coleta seletiva porta a porta, o que na prática não se concretizou. Esse fato levou à exclusão da amostra, para a segunda etapa de pesquisa, dos bairros sorteados com base na estratificação coleta seletiva autônoma,ou seja, os bairros Mata da Praia (classe A) e Bairro de Lourdes (classe C). Assim, a segunda etapa de pesquisa qualitativa foi realizada nos bairros: Jardim Camburi, Praia do Suá, Jucutuquara e Ilha de Monte Belo, como apresenta o Quadro 7.

Quadro 7 - Bairros selecionados para a segunda etapa da pesquisa qualitativa, segundo classe sócio-econômica e estratificação por modalidade de coleta seletiva, em Vitória.

\begin{tabular}{|c|c|c|}
\hline Classe sócio-econômica & $\begin{array}{c}\text { Bairro(s) sorteados } \\
\text { para Pesquisa }\end{array}$ & $\begin{array}{c}\text { Estratificação } \\
\text { (modalidade CS) }\end{array}$ \\
\hline A & - & - \\
\hline \multirow{2}{*}{ B } & Jardim Camburi & porta a porta (a) \\
\cline { 2 - 3 } & Praia do Suá & PEVs (c) \\
\hline
\end{tabular}




\begin{tabular}{|c|l|c|}
\hline \multirow{2}{*}{ C } & Jucutuquara & PEVs (c) \\
\cline { 2 - 3 } & Ilha de Monte Belo & porta a porta (d) \\
\hline D & - & - \\
\hline
\end{tabular}

Da mesma forma que na etapa anterior, em cada um dos bairros sorteados foram realizadas oito entrevistas, considerando-se as categorias já adotadas na $1^{\mathrm{a}}$ etapa.

Assim, foram realizadas 48 entrevistas na primeira etapa e 32 entrevistas na segunda etapa, num total de 80 entrevistas.

A segunda etapa da pesquisa qualitativa de campo foi realizada em maio de 2003, período que corresponde a cerca de 8 meses após o inicio da ampliação da coleta seletiva, através de postos de entrega voluntária (setembro/2002) e a 6 meses da implantação da coleta seletiva porta a porta (novembro/2002).

Os resultados foram tabulados em planilhas, que encontram-se no Anexo 4, de acordo com a metodologia da Análise do Discurso do Sujeito Coletivo, proposta por LEFÉVRE e LEFÉVRE (2002).

Para permitir a análise global dos resultados, as planilhas foram posteriormente agrupadas, em função da etapa da pesquisa e modelo do questionário adotado, do sujeito, da idéia central síntese e da ancoragem síntese, que são figuras metodológicas da Análise do Discurso do Sujeito Coletivo.

Elaborou-se também os respectivos DSC para os diversos sujeitos coletivos identificados.

\section{II - Pesquisa Quantitativa - Participação da População na Coleta Seletiva}

Fase 4 - Pesquisa via internet

As pesquisas realizadas via internet tiveram como principal característica o acesso limitado aos usuários desta rede mundial de informações, o que seleciona um extrato populacional. 
A administração municipal de Vitória possui site oficial com objetivo de disponibilizar informações e serviços on line de interesse aos seus munícipes, que por sua vez é subdividido em páginas correspondentes às diversas secretarias municipais que compõem a estrutura da administração pública local. Contando com esse recurso e a partir do apoio do setor de comunicação da prefeitura de Vitória, foi possível realizar pesquisa quantitativa via internet sobre coleta seletiva.

O público que acessa o site da prefeitura de Vitória é formado principalmente por pessoas ligadas direta ou indiretamente á administração pública, inclusive de outros municípios e estados, cidadãos de Vitória em geral e pesquisadores.

O instrumento de coleta de dados utilizado foi elaborado em conjunto com os jornalistas responsáveis pelo site e constou de seis perguntas fechadas e uma aberta, formuladas de forma objetiva e com linguagem acessível.

Os objetivos traçados para esta etapa da pesquisa foram:

- Verificar se o público que utiliza o site da prefeitura sabe o que é coleta seletiva e qual é sua fonte de informações;

. Conhecer a motivação desse grupo de pessoas em participar de programa de coleta seletiva;

Após ser elaborado, o questionário (anexo 5) foi instalado na página da Secretaria Municipal de Serviços, a qual era responsável pela Coleta Seletiva no âmbito da prefeitura municipal.

Durante o primeiro mês em que a pesquisa foi colocada no ar, houve uma chamada na página principal do site, contendo uma pergunta destacada do questionário, de modo a atrair a atenção das pessoas. Ao responder a pergunta, o internauta era convidado a participar, acessando e preenchendo o questionário completo.

Observou-se maior acesso das pessoas à pesquisa no primeiro mês em que ficou no ar com a chamada na página principal do site, o qual foi gradativamente sendo reduzido ao longo dos meses subseqüentes. Foi contabilizada a participação de 73 pessoas no período de agosto a novembro de 2002 .

Fase 5 - Pesquisa com pessoal interno da prefeitura e empresas contratadas Utilizando-se como base o questionário da pesquisa via internet, foi elaborado um formulário e aplicado ao pessoal que atua, direta ou indiretamente, na coleta seletiva, 
no âmbito da prefeitura municipal de Vitória, durante o período de setembro a outubro de 2002.

O objetivo dessa pesquisa foi conhecer a visão deste grupo, que é responsável pelo gerenciamento e operação da coleta seletiva no município de Vitória.

A amostra de vinte indivíduos foi estratificada, buscando-se atingir os setores mais representativos do universo pesquisado, resultando nos setores apresentados no Quadro 8.

Quadro 8 - Setores selecionados para a Fase 5 da pesquisa, segundo sua origem.

\begin{tabular}{|c|l|}
\hline \multicolumn{1}{|c|}{ Origem } & \multicolumn{1}{c|}{ Setor } \\
\hline \multirow{4}{*}{ Prefeitura Municipal } & Gabinete Secretário e Sub- Secretário \\
\cline { 2 - 2 } & Departamento de Limpeza Pública \\
\cline { 2 - 2 } & Departamento de Educação Ambiental \\
\cline { 2 - 2 } & Usina de Lixo \\
\hline \multirow{2}{*}{ Empresas contratadas para } & $\begin{array}{l}\text { Empresa de coleta e destinação final de } \\
\text { resíduos sólidos urbanos A A }\end{array}$ \\
\cline { 2 - 2 } fornecer serviços de Limpeza Pública & $\begin{array}{l}\text { Empresa de varrição e coleta de resíduos } \\
\text { sólidos urbanos B }\end{array}$ \\
\hline
\end{tabular}

Na entrega do formulário (anexo 6) manteve-se contato pessoal com os responsáveis pelos diversos setores contemplados na amostra. Após uma breve explanação sobre o objetivo da pesquisa, as pessoas envolvidas direta e/ou indiretamente com a coleta seletiva foram convidadas a responder ao formulário.

A seguir apresenta-se no Capítulo 6, que trata dos resultados e discussão, o relato das experiências de coletas seletivas brasileiras que foram visitadas e os resultados da presente pesquisa. 


\section{RESULTADOS E DISCUSSÃO}

A seguir, são apresentados os resultados da presente tese, seguindo as etapas metodológicas apresentadas no capítulo 5, que respondem às hipóteses formuladas no capítulo 3.

Como produto final da etapa metodológica denominada fase 1 , foi instituído grupo de indicadores de referência para o planejamento e a avaliação de desempenho de Programas de Coleta Seletiva.

A partir do grupo de indicadores estabelecido foi realizado estudo de caso para o município de Vitória - ES (fase 2) e nas fases 3 a 5 foram pesquisados aspectos da participação social.

Inicialmente, como parte da etapa metodológica para o estabelecimento de grupo de indicadores (fase1), foram visitados alguns programas de coleta seletiva implantados no país e desenvolvidos por governos municipais, com o objetivo de se conhecer aspectos operacionais e observar como se dá a integração da participação social nas experiências desenvolvidas.

\subsection{Experiências de Coleta Seletiva em governos municipais}

Os programas de coleta seletiva visitados e aqui relatados compreendem os municípios de São Bernardo do Campo-SP, Porto Alegre-RS, Florianópolis-SC, Santo André-SP e Vitória-ES.

Em 21 de março de 2001 foram realizadas visitas aos município de São Bernardo do Campo, onde há um programa de coleta seletiva desenvolvido pela municipalidade, empregando-se a modalidade de coleta por meio de postos de entrega voluntária PEVs.

No período de 22 a 26 de abril de 2002 foi realizada visita técnica aos municípios de Porto Alegre-RS, Florianópolis-SC e Santo André-SP, juntamente com a equipe técnica da Prefeitura Municipal de Vitória, ES. Esses municípios foram selecionados por terem sido considerados, por estes técnicos, como referência em coleta seletiva porta a porta, modalidade na qual a equipe de Vitória ainda não tinha vivência prática. 
Ao longo do período de janeiro de 2002 até maio de 2003 foi realizado acompanhamento e registro da experiência de coleta seletiva do município de Vitória-ES.

As informações sobre os Programas de Coleta Seletiva implantados, nesses municípios visitados, foram sistematizadas nos seguintes tópicos: modalidades de coleta seletiva, operação do programa de coleta seletiva, aspectos da participação social no programa de coleta seletiva, aspectos de custos e produção do programa de coleta seletiva e avaliação do programa de coleta seletiva.

\subsubsection{Coleta Seletiva em São Bernardo do Campo-SP}

O município de São Bernardo do Campo, com população de 723.132 hab, tem as atividades de limpeza pública e de coleta seletiva a cargo do Departamento Municipal de Limpeza Pública.

A seguir apresentam-se as informações obtidas:

- Modalidades de coleta seletiva-

O município de São Bernardo do Campo operava com coleta seletiva por meio de PEVs.

A concepção do projeto para a coleta seletiva em São Bernardo do Campo baseavase na utilização de ECOPONTOS: pontos de entrega voluntária, dotados de recipientes coloridos de acordo com as cores padronizadas nacionalmente para a reciclagem, confeccionados em polietileno de alta densidade (PEAD).

- Operação do programa de coleta seletiva

Visando garantir melhores condições operacionais para o programa de coleta seletiva implantado, a prefeitura havia contratado uma empresa, por 5 anos, para instalar recipientes para armazenamento de materiais recicláveis, com programação visual definida pela prefeitura, manter e operar os ECOPONTOS, contando com o efetivo de 1 motorista e 2 ajudantes por equipe.

A coleta dos materiais recicláveis acumulados nos recipientes de $240 \mathrm{~L}$ e de $2500 \mathrm{~L}$, instalados nos postos de entrega voluntária, era feita por meio de veículo, 
especialmente, adaptado com operação semi-automática, conforme ilustram as figuras 6 e 7 .

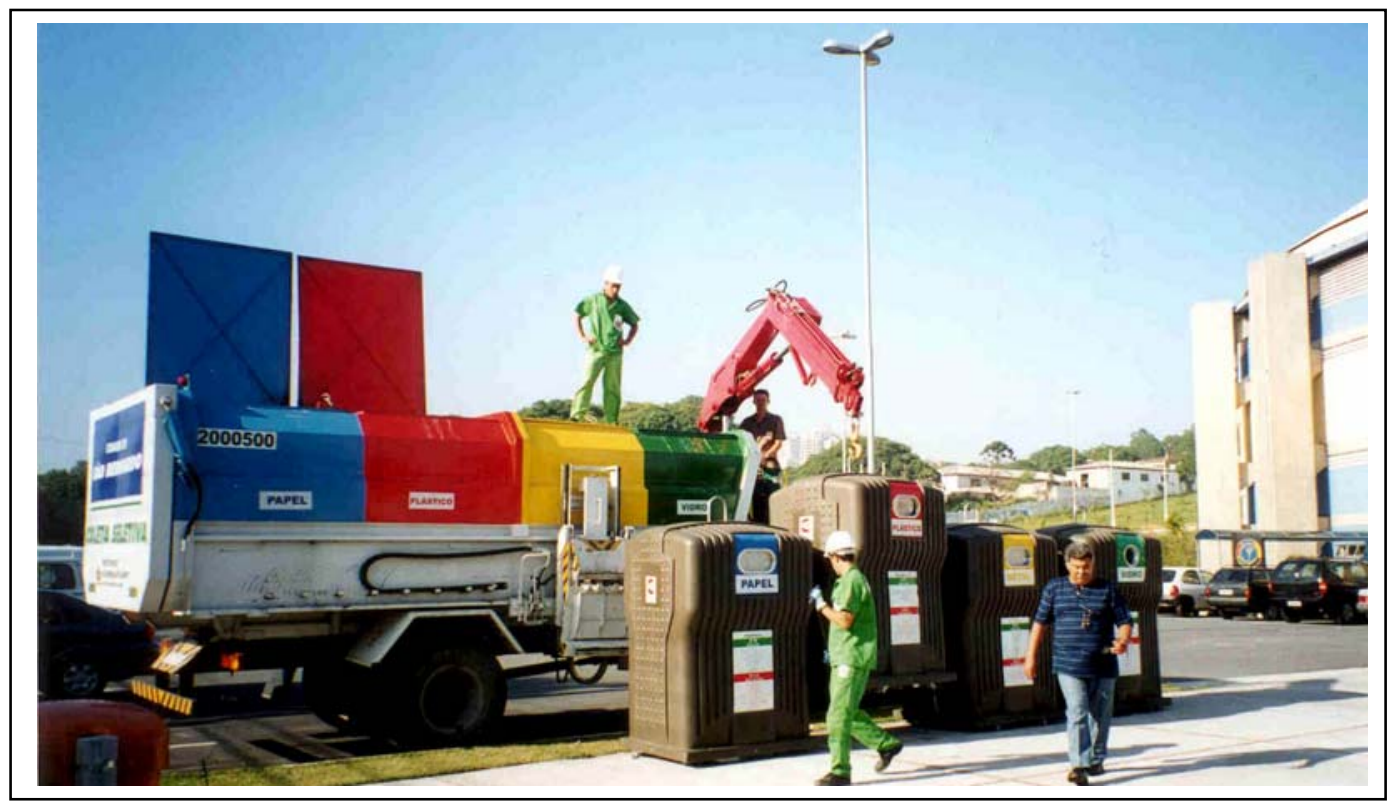

Figura 6 - Coleta de materiais recicláveis armazenados em recipientes de 2500 L, nos ECOPONTOS, São Bernardo do Campo, 2001.

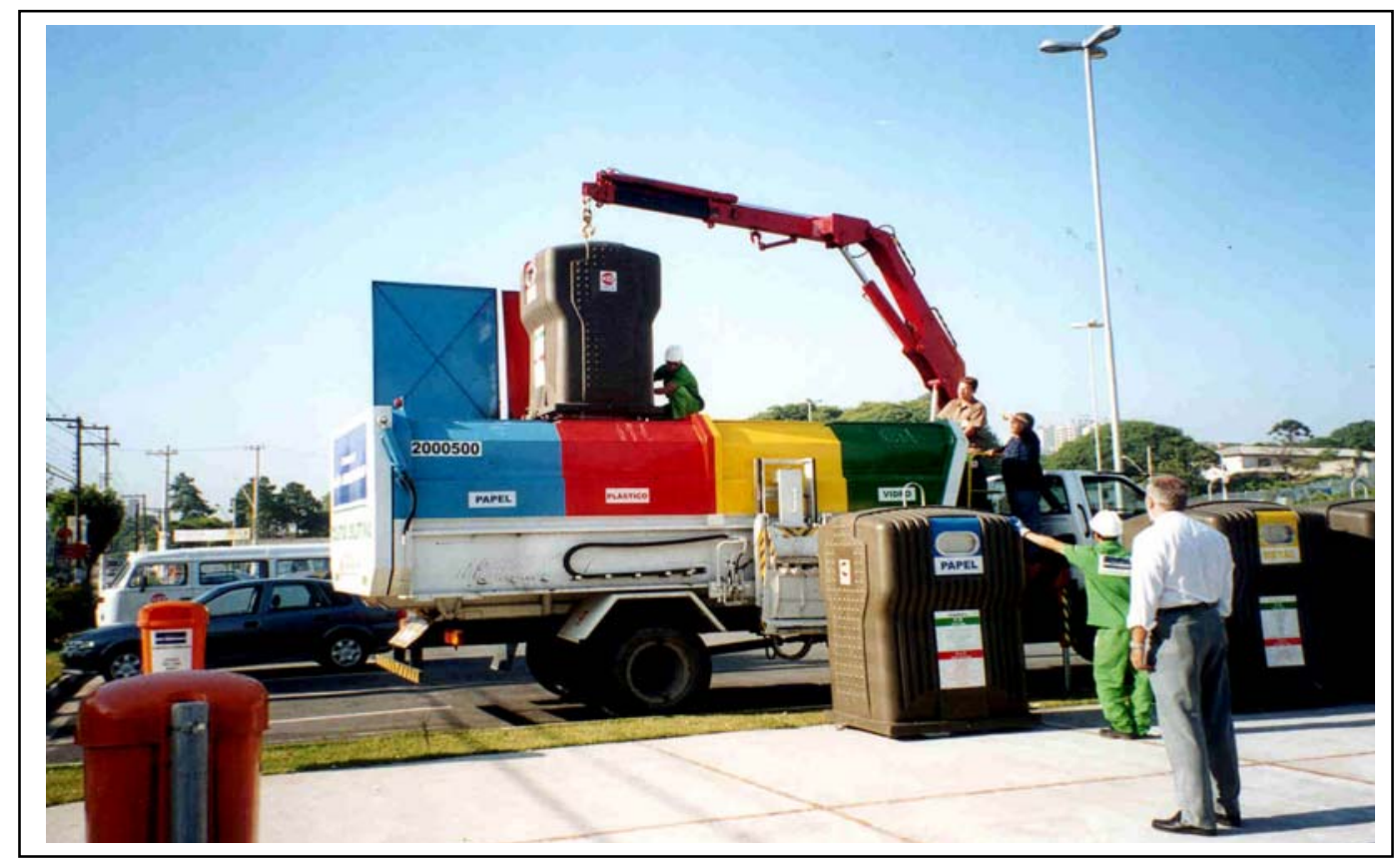

Figura 7 - Coleta de materiais recicláveis armazenados em recipientes de 2500 L, nos ECOPONTOS, São Bernardo do Campo, 2001. 
Inicialmente, foram instalados 36 ECOPONTOS, quantidade gradativamente ampliada, chegando a 145 unidades, em março de 2001. No momento da visita, o programa operava com 4 veículos de coleta, dotados de carroceria especial, sendo um deles com equipamento munk para coleta dos recipientes de $2500 \mathrm{~L}$.

A empresa contratada também era encarregada de realizar a limpeza e manutenção dos ECOPONTOS, os quais eram lavados semanalmente por equipes de limpeza.

No programa de coleta seletiva, em operação na cidade desde 2001, destinavam-se os materiais recicláveis coletados a organizações de catadores implantadas em parceria com a UNICEF, patrocinadora do Fórum Lixo e Cidadania (Programa criança no lixo nunca mais), que tinha, entre seus objetivos, desativar o lixão existente na região de mananciais, conhecido como Lixão do Alvarenga, encaminhando os catadores adultos para trabalharem na Casa de Reciclagem e Cidadania. Todo material reciclável coletado era encaminhado à Casa de Reciclagem e Cidadania para triagem e posterior comercialização.

- Aspectos da participação social no programa de coleta seletiva

No lançamento do programa de coleta seletiva de São Bernardo do Campo junto à população foi realizado um amplo trabalho de divulgação utilizando-se como mídia: rádio, $\mathrm{TV}$, jornais, etc.

Com o objetivo de apresentar o programa aos formadores de opinião do município, a prefeitura municipal promoveu um evento para o seu pré-lançamento com a participação estimada de 500 pessoas.

A concepção dos técnicos envolvidos, no programa de coleta seletiva visitado, era de que as ações de divulgação e sensibilização deveriam acontecer, sistematicamente, por, no mínimo, 2 anos, o que não ocorreu na prática em São Bernardo do Campo.

A equipe da prefeitura considerava que o programa havia sido muito bem aceito pela população local, que vinha participando ativamente; no entanto, não dispunha de informações sobre os percentuais dessa participação social. 
- Aspectos de custos e produção do programa de coleta seletiva

O custo operacional, de março de 2001, do programa de coleta seletiva implantado em São Bernardo do Campo, era de R \$ 600,00/equipe de coleta/dia, sendo incluída a depreciação de veículos e equipamentos que, ao final de 5 anos, deveriam ser entregues pela empresa contratada ao município.

Quanto ao desempenho da coleta, foi informado que o veículo equipado com munk, num roteiro com duração média de 4 horas, percorria entre 40 e 50 km e coletava cerca de 5 ECOPONTOS com recipientes de $2500 \mathrm{~L}$ e 16 com recipientes de $240 \mathrm{~L}$. Os demais veículos coletavam 21 ECOPONTOS com recipientes de 240 L, nas mesmas condições anteriores de tempo e distância.

O rendimento de trabalho da equipe de limpeza era de 21 ECOPONTOS por dia.

Não foram apurados dados de custo e produção das etapas de triagem e beneficiamento.

- Avaliação do programa de coleta seletiva implantado em São Bernardo do Campo

A estratégia de contratar uma empresa para operar os ECOPONTOS e a coleta de materiais recicláveis apresentava-se adequada. Havia, ainda, a necessidade de ajustes no veículo de coleta empregado no programa de coleta seletiva, visando melhorar o desempenho operacional e dar maior segurança aos trabalhadores.

A importância atribuída pela equipe da prefeitura à manutenção dos ECOPONTOS limpos e em bom estado contribuía, na visão da equipe técnica local, para o adequado funcionamento do programa. Entretanto, não foram disponibilizados dados históricos sobre o desempenho do programa e tampouco indicadores, de modo sistematizado, que pudessem contribuir para a presente pesquisa.

A grande dificuldade enfrentada no desenvolvimento do programa de coleta seletiva implantado estava no processo de integração entre o programa municipal e os catadores autônomos de material reciclável.

Os sucateiros vinham utilizando os catadores para desviar materiais recicláveis de maior valor econômico dos ECOPONTOS. Tal situação gerava constantes ocorrências de danos aos equipamentos, além de prejudicar o funcionamento das Casas de Reciclagem e Cidadania, que deixavam de receber a matéria-prima 
necessária ao desenvolvimento de suas atividades. Assim, a administração municipal havia formado uma Comissão composta por várias secretarias municipais e entidades afins para buscar alternativas para enfrentar esse problema.

\subsubsection{Coleta Seletiva em Porto Alegre}

O município de Porto Alegre possuía população de 1.360 .000 habitantes e as atividades de limpeza pública e de coleta seletiva estavam a cargo do Departamento Municipal de Limpeza Urbana-DMLU.

O sistema de coleta regular de resíduos sólidos domiciliares coletava 900 a 1000 t/ dia de resíduos sólidos domiciliares, realizando coleta diária nas zonas comerciais e coleta alternada em bairros periféricos.

A seguir são apresentadas as informações obtidas:

- Modalidades de coleta seletiva

O municipio de Porto Alegre operava com as modalidades de coleta seletiva porta a porta e por meio de postos de entrega voluntária

A coleta seletiva porta a porta foi iniciada em Porto Alegre, em 1990, no bairro Bonfim, de classe média, que abrigava aproximadamente 100.000 habitantes, devido à existência de trabalho de cunho ambiental, realizado por diversas ONG's, tendo crescido gradativamente para os bairros no entorno. Em 2002, estava implantada, e em funcionamento, em 100\% do município, tendo uma freqüência de coleta semanal. Devido a ações de vandalismo, a coleta seletiva por meio de postos de entrega voluntária estava operando em menor escala, com PEVS instalados em locais fechados, geralmente, órgãos públicos.

- Operação do programa de coleta seletiva

A gerência responsável pela operação da coleta seletiva adotava a medida de não coletar os resíduos sólidos que não estivessem adequadamente separados, no dia especificado para a coleta seletiva porta a porta.

Caso fosse constatada irregularidade na apresentação dos resíduos sólidos para coleta seletiva porta a porta em grande gerador, como condomínio, por exemplo, a guarnição de coleta informava a ocorrência à chefia imediata, a qual acionava a 
fiscalização para ir ao local e realizar ação de orientação e/ou fiscalização, visando, com isso, a corrigir o problema.

Para os pequenos geradores, como as unidades residenciais, o resíduo sólido apresentado à coleta seletiva porta a porta de forma inadequada e, portanto, geralmente não coletado, desencadeava a ação imediata do cidadão, o qual contatava o DMLU, via linha telefônica específica, para solicitar esclarecimentos ou fazer sua reclamação. Neste momento, era feita nova orientação ao cidadão quanto aos corretos procedimentos para separar e apresentar os resíduos para a coleta.

O gerenciamento do serviço de coleta seletiva, no período da visita, estava centralizado na Gerência de Coleta do DMLU, que também era responsável pela coleta regular de resíduos sólidos urbanos.

Como estratégia de operação da coleta seletiva porta a porta, o DMLU destacava, da guarnição da coleta seletiva, um gari, também conhecido como gari juntador ou gari coelho, que seguia na frente da equipe, acumulando os recicláveis em pontos estratégicos (figura 8), para facilitar a coleta.

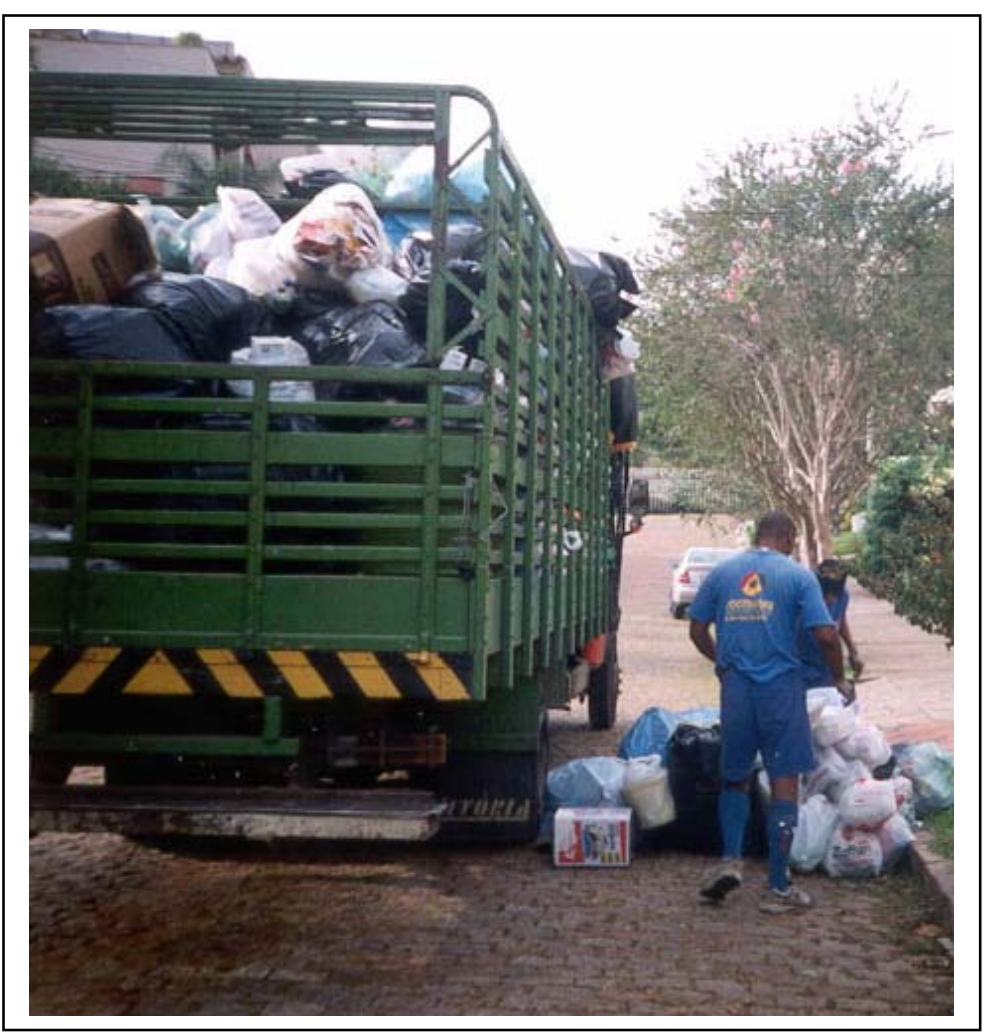

Figura 8 - Operação da coleta seletiva porta a porta, Porto Alegre, 2002. 
O pessoal que trabalhava na coleta era resistente quanto à utilização de EPIs e uniformes, sendo que os coletores utilizavam luvas sem as pontas dos dedos (figura 9), especialmente adaptadas por solicitação dos mesmos, visando a facilitar a identificação do material reciclável.

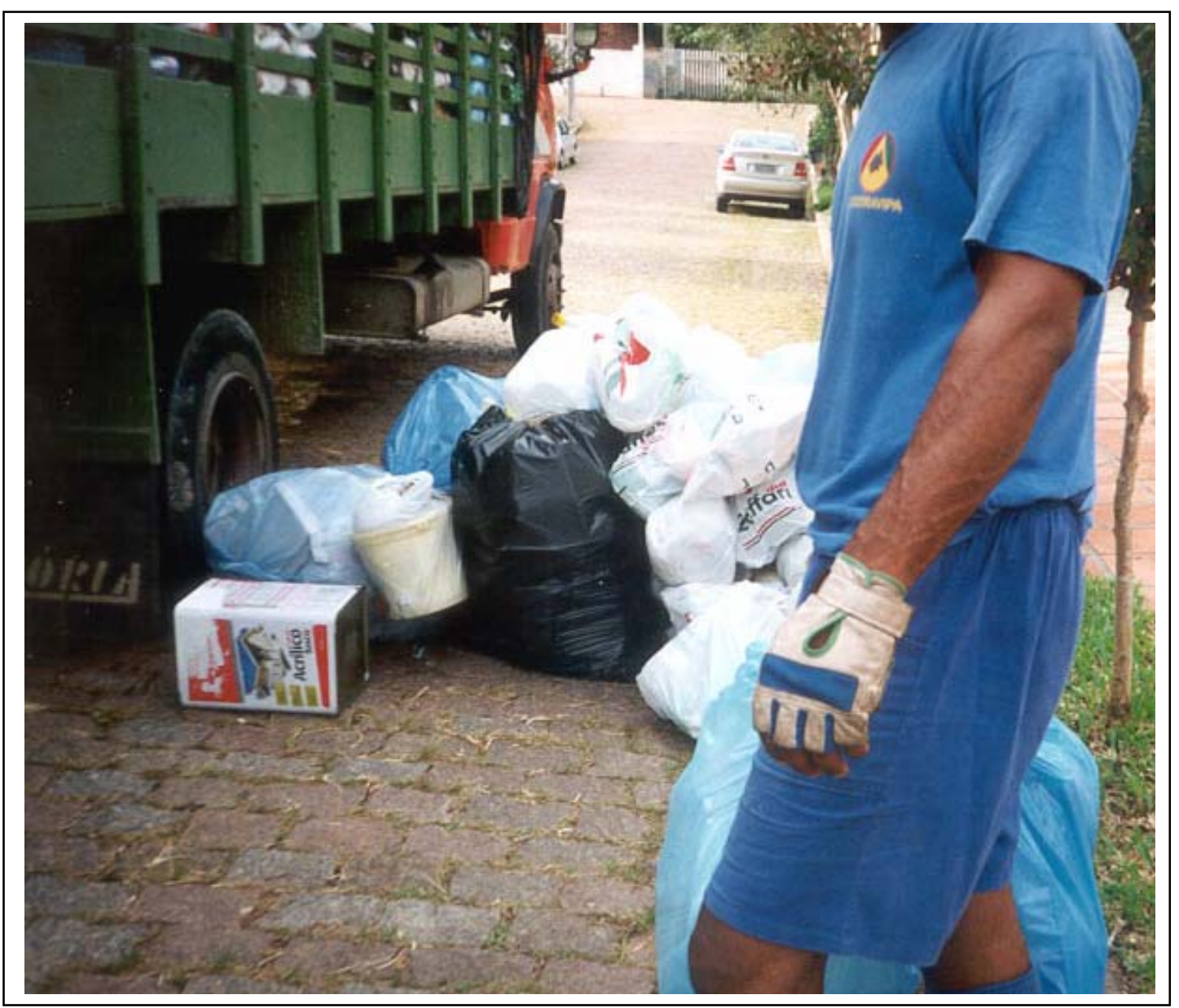

Figura 9 - Coleta seletiva porta a porta, detalhe do EPI utilizado, Porto Alegre, 2002.

Os materiais recicláveis coletados eram levados diretamente às Unidades de Triagem e Reciclagem e descarregados manualmente (figura10), não existindo a pesagem das quantidades coletadas. Nessas unidades, os catadores autônomos, organizados em associações ou cooperativas, trabalhavam na separação e comercialização dos resíduos sólidos triados. 


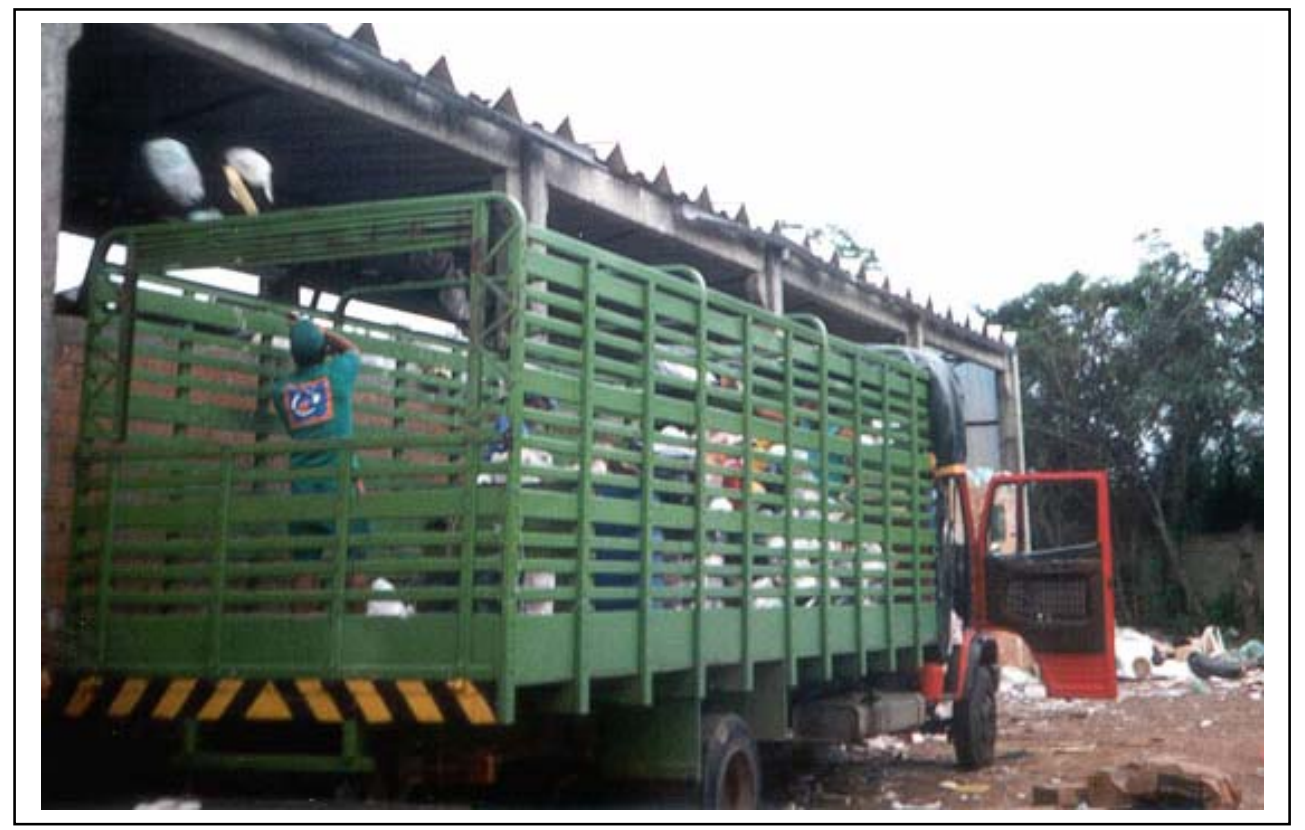

Figura 10 - Operação de descarga do caminhão da coleta seletiva porta a porta, Porto Alegre, 2002.

Essas unidades, em número de 9, estavam distribuídas estrategicamente pela cidade, e foram organizadas pelo poder público, que possuía uma política de qualificação, agregação de valores e comercialização do material triado.

Na administração municipal de Porto Alegre existia uma política de gerenciamento integrado que visava à remoção das populações residentes em áreas de risco ou impróprias, e o posterior reassentamento das famílias em locais que contavam com estrutura de urbanização e regularização fundiária, as chamadas vilas populares.

A proposta central do trabalho era a inclusão social e, sendo assim, optaram pela instalação de Unidades de Triagem junto às vilas, nas quais foram reassentadas populações deslocadas de áreas de risco da cidade.

Tal alternativa baseou-se no fato de que parte dessas populações já atuavam anteriormente na catação informal de materiais recicláveis, por residirem próximo aos centros geradores. Com sua transferência para tais reassentamentos, passaram a residir em pontos mais distantes da cidade e a prefeitura passou a levar os resíduos sólidos recicláveis para serem triados por essas pessoas, em regime de cooperativa. 
Para uma organização popular assumir a operação de uma unidade de triagem era firmado um convênio entre a prefeitura e a associação de catadores, sendo que a contra-partida dos trabalhadores era receber e processar resíduos da coleta seletiva.

Durante a visita conheceu-se a Unidade de Triagem e Reciclagem da Vila Cavalhada.

A Unidade de Triagem e Reciclagem da Vila Cavalhada (figura 11 a 13) foi criada em 1996, com 20 associados e, em 2002, estava operando com 46 trabalhadores.

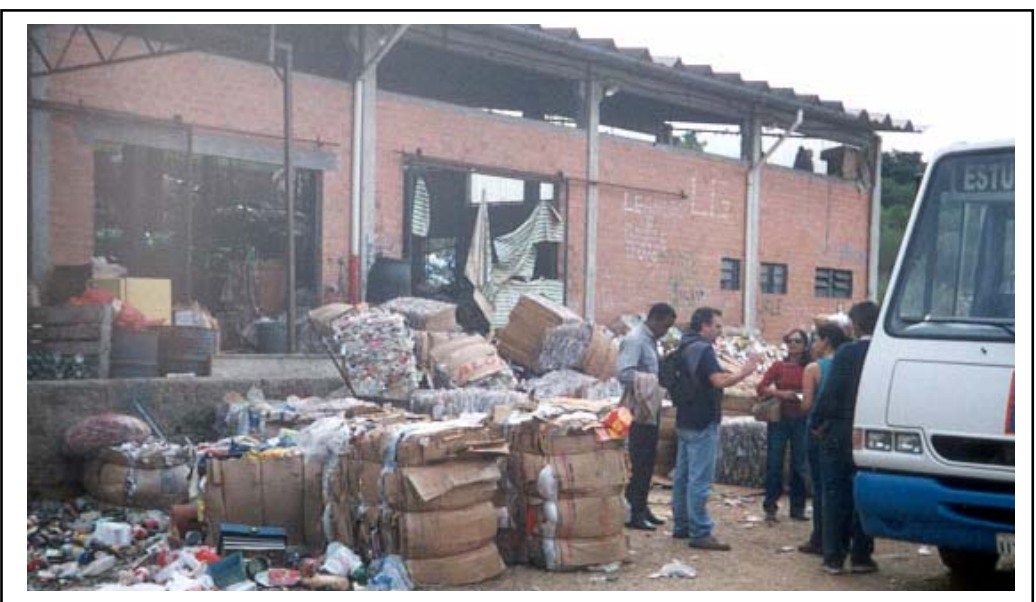

Figura 11 - Unidade de Triagem e Reciclagem de Vila Cavalhada, Porto Alegre, 2002

A prefeitura doou o prédio, as máquinas e a assessoria técnica por cerca de um ano, até que a entidade pudesse se manter por conta própria, como forma de apoio à associação.

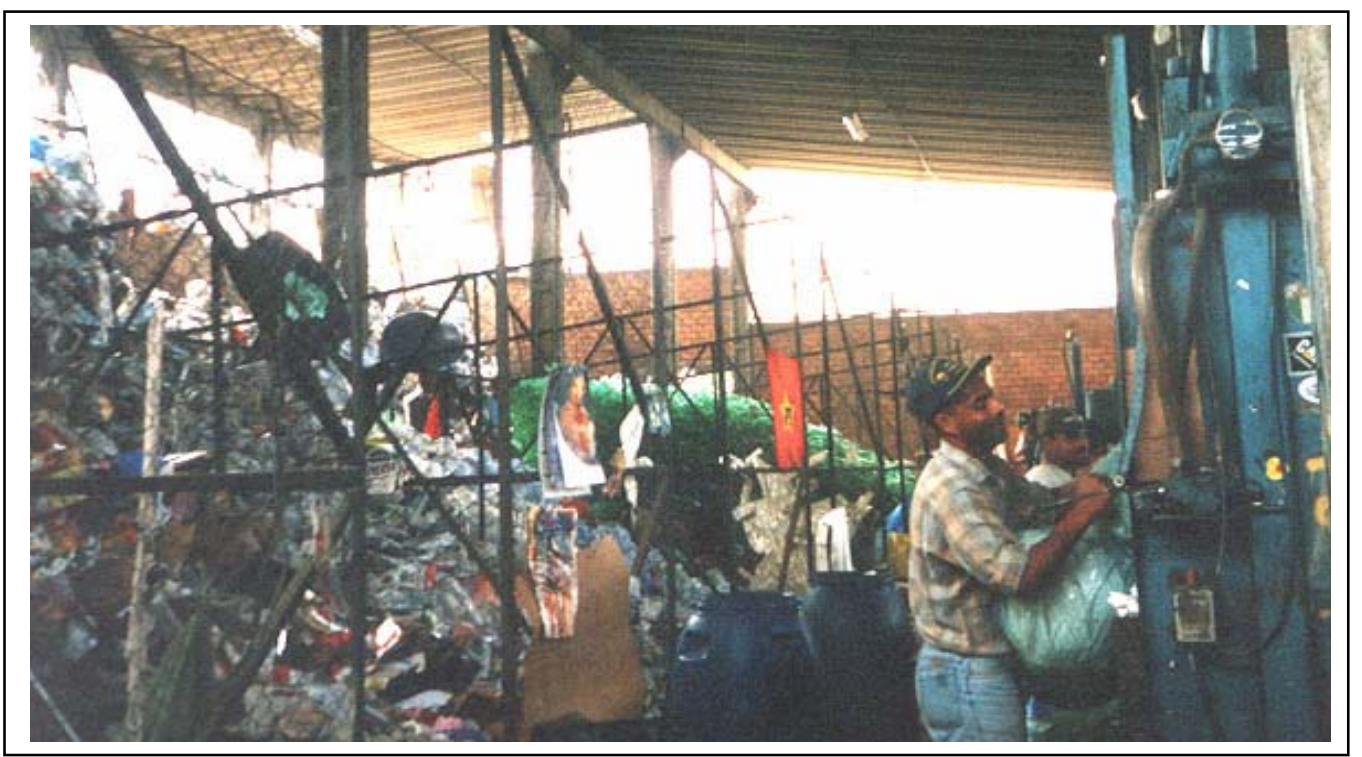


Figura 12 - Unidade de Triagem e Reciclagem de Vila Cavalhada, Porto Alegre, 2002

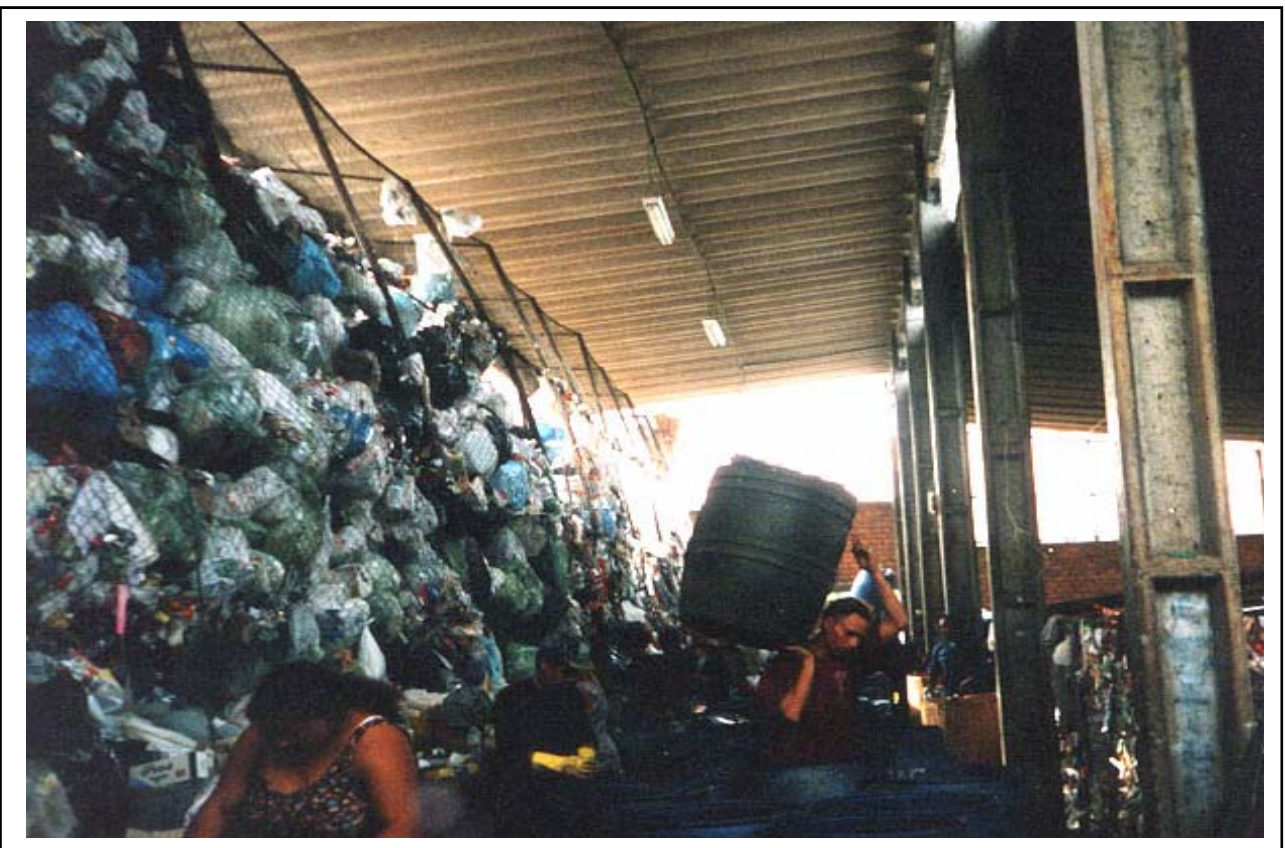

Figura 13 - Unidade de Triagem e Reciclagem de Vila Cavalhada, Porto Alegre, 2002

Nas unidades de triagem, todos os associados trabalhavam na separação dos resíduos, inclusive os membros da diretoria, sendo as receitas e despesas rateadas, igualmente, entre todos os membros da cooperativa.

Segundo os catadores, o melhor material que chegava até a unidade de triagem visitada eram as embalagens recicláveis originadas em estabelecimentos hospitalares, uma vez que os materiais recicláveis vindo da coleta seletiva em residências, geralmente, chegavam sujos, pois a maioria das pessoas não lavavam as embalagens antes do descarte.

A equipe do DMLU informou a existência de outra unidade de triagem denominada Centro de Educação Ambiental da Vila Pinto, onde o trabalho realizado com os catadores iria além da atividade de triagem de materiais recicláveis. Nesse Centro, eram desenvolvidas oficinas de artesanato e de papel reciclado, oferecidas aulas de 
música para os filhos dos catadores, através de convênio com a escola de música, aulas de teatro, etc, além de ações de sensibilização com toda a comunidade.

As associações de catadores estavam ligadas a uma Federação Estadual, que tinha como função a busca de parceiros e a qualificação do pessoal.

Durante a visita, verificou-se que o sistema de coleta seletiva por meio de PEVs era pouco difundindo em Porto Alegre. A operação, em abril de 2002, era realizada com 30 unidades instaladas em pontos estratégicos da cidade, tendo como critério de localização a existência de órgãos públicos dispostos a cederem espaço e apoio operacional, visando minimizar o vandalismo (figura 14).

Em casos especiais, realizavam parcerias com condomínios, nas quais o DMLU cedia os recipientes coletores para serem colocados nos PEVs. No geral, a equipe do DMLU possuía experiência positiva quanto à coleta seletiva em condomínios, existindo folhetos educativos e legislação específica para tal segmento da cidade.

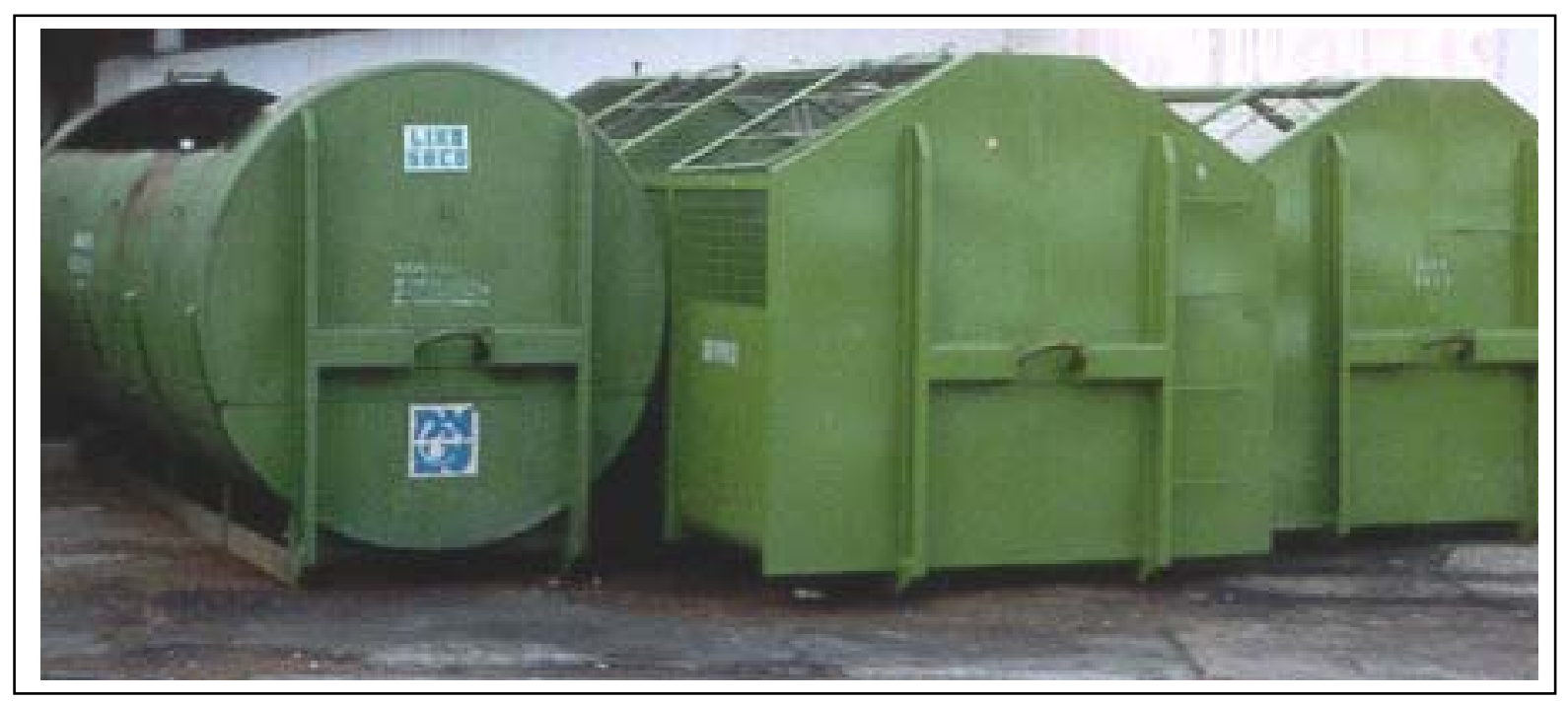

Figura 14 - PEV utilizado em órgãos públicos e condomínios, Porto Alegre, 2002.

Os PEVs instalados em órgãos públicos, no geral, não ficavam acessíveis ao público durante a noite e nos finais de semana e feriados. Os PEVs utilizados eram metálicos, com as 4 divisões para distintos materiais.

Com o objetivo de unifomizar os conceitos repassados à população quanto à separação do lixo para a coleta seletiva porta a porta e por meio de PEVs, o pessoal do DMLU estava promovendo a gradativa adequação dos recipientes utilizados para 
o conceito resíduo seco e resíduo úmido, o que já se podia verificar em parques da cidade (figura 15).

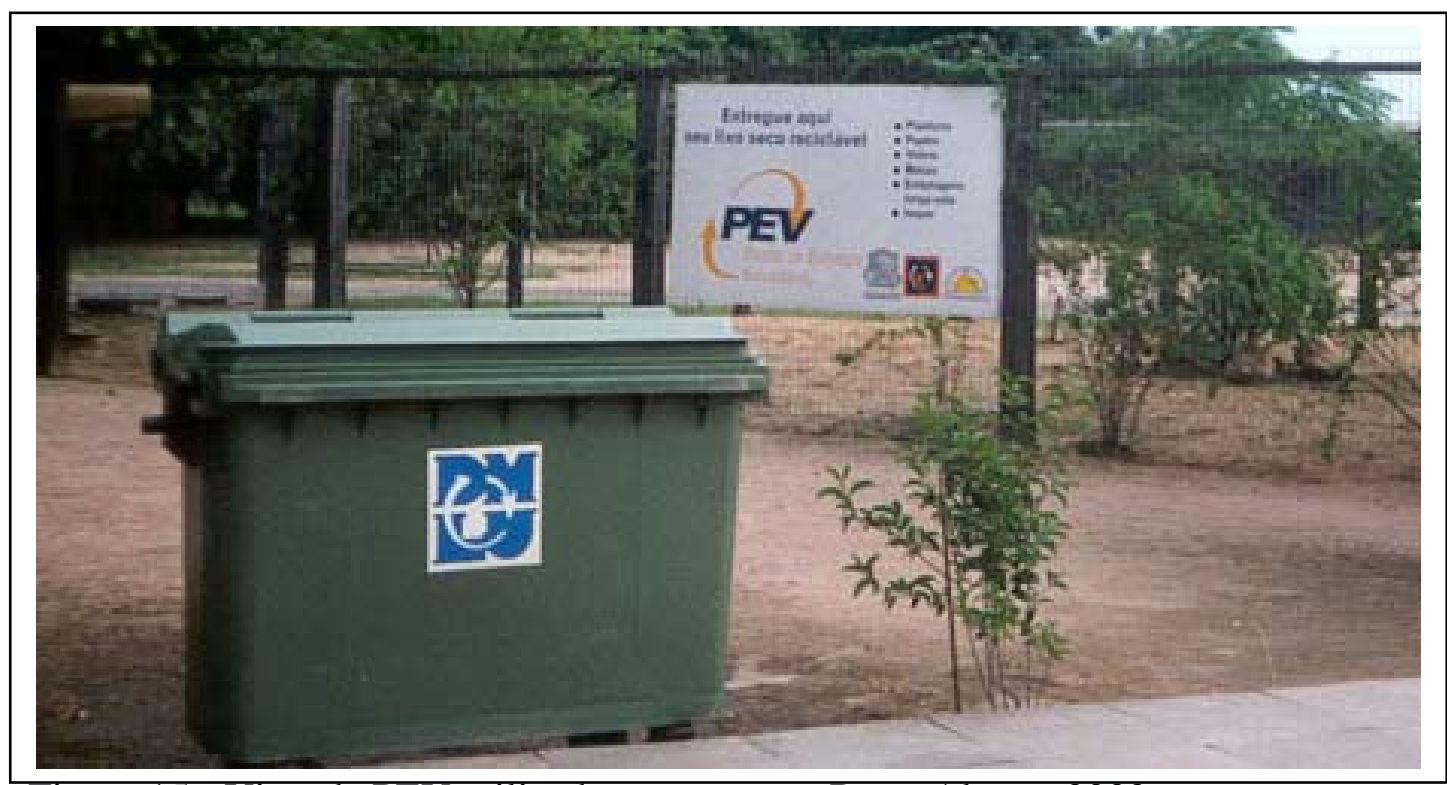

Figura 15 - Vista de PEV utilizado em parques, Porto Alegre, 2002.

- Aspectos da participação social no programa de coleta seletiva

O trabalho de divulgação e sensibilização para a implantação da coleta seletiva porta a porta foi feito utilizando-se carro de som e visitas a todas as residências localizadas na área contemplada pelo programa, com a participação dos garis, ONG’S e funcionários no DMLU.

Em 1996, a coleta seletiva foi expandida a todo município e a questão financeira, nessa época, só possibilitou a divulgação deste serviço à comunidade por meio de rádio e carro de som.

Segundo a representante dos catadores da Unidade de Triagem da Vila Cavalhada, depois que a prefeitura iniciou o trabalho nas escolas, que incluía visitas didáticas às unidades de triagem, com a colaboração dos professores, a qualidade dos materiais recicláveis coletados havia melhorado bastante, reduzindo a quantidade de matéria orgânica misturada. 
Não há dados concretos sobre a efetiva participação da população no programa de coleta seletiva implantado. A estimativa era que essa participação se dava em torno de $20 \%$.

A equipe do DMLU informou que a população de Porto Alegre demandava o aumento da freqüência da coleta seletiva porta a porta, não havendo, no momento da visita, condições para ampliar o programa implantado, sem equacionar os problemas operacionais existentes.

- Aspectos de custos e produção do programa de coleta seletiva

Como o material reciclável coletado era diretamente transportado e entregue às unidades de triagem, e nestes locais não existia balança rodoviária, a quantidade de resíduo sólido coletada, pela coleta seletiva porta a porta, era estimada. O programa realizava campanhas periódicas de pesagem e estimou que uma carga de $26 \mathrm{~m}^{3}$ tinha o peso de $1500 \mathrm{~kg}$, ou seja, uma densidade de $57,7 \mathrm{~kg} / \mathrm{m}^{3}$.

Em termos da estrutura operacional, a coleta seletiva porta a porta era realizada por 25 caminhões com carroceria aberta, de capacidade entre 20 a $30 \mathrm{~m}^{3}$, cada um, que operavam com 3 a 4 ajudantes conforme o bairro. Realizavam, semanalmente, cerca de 100 roteiros de coleta, com cerca de $10 \mathrm{~km}$ de extensão e velocidade média de 20 $\mathrm{km} / \mathrm{h}$. O motorista tinha que preencher, rotineiramente, um formulário com informações sobre o itinerário percorrido.

Na operação da coleta seletiva, o município contava com efetivo total de 120 pessoas, inclusive para a coleta dos PEVs, sendo este montante formado por 32 motoristas e 88 coletores, distribuídos entre cooperativados e funcionários do DMLU. Havia um índice de cerca de 20 \% de absenteísmo entre os funcionários do DMLU, além de problemas de dependência química em relação ao efetivo que atua na coleta.

Durante a visita à Unidade de Triagem e Reciclagem da Vila Cavalhada, esta operava com 46 trabalhadores, em regime de 8 horas/dia, realizando a triagem e enfardamento de 8 a 9 toneladas de recicláveis por semana. Estimava-se que este total representava a recuperação de $70 \%$ do material reciclável coletado e entregue na unidade. 
Um grande problema enfrentado pelo poder público local era a ação dos catadores avulsos que faziam a rota da coleta porta a porta previamente e desviavam grande parte do resíduo reciclável antes da coleta seletiva (figuras 16 e 17). Com isto, os materiais de maior valor de mercado, como alumínio, não chegavam às unidades de triagem.

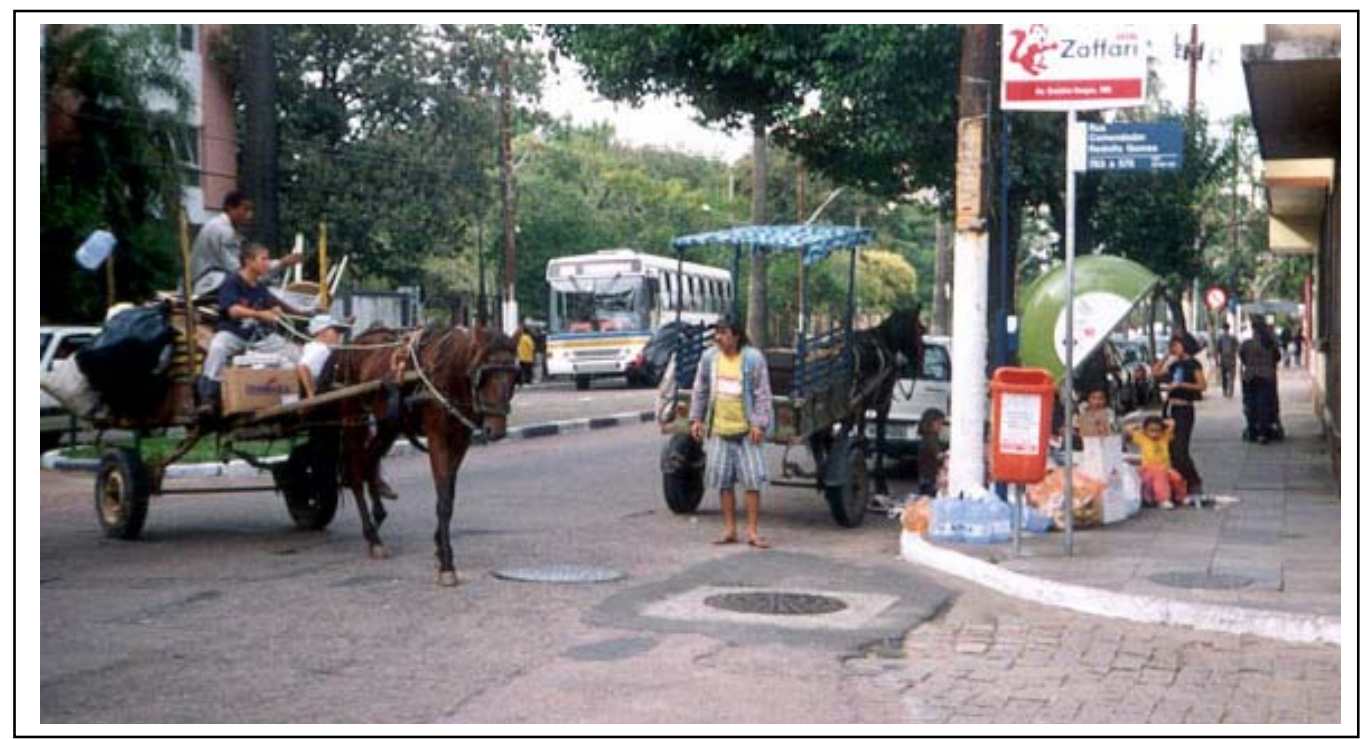

Figura 16 - Ação de catadores, nos roteiros da coleta seletiva porta a porta, Porto Alegre, 2002.

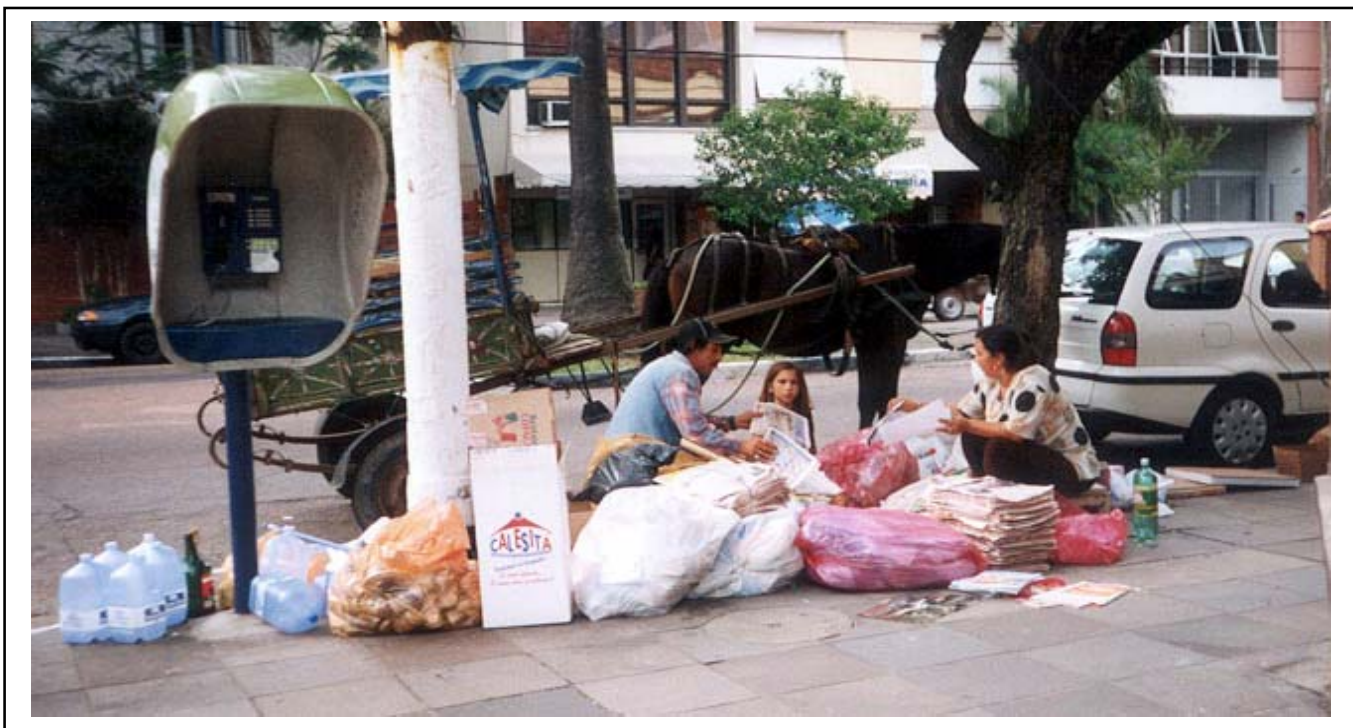

Figura 17 - Ação de família de catadores, nos roteiros da coleta seletiva porta a porta, Porto Alegre, 2002. 
- Avaliação do programa de coleta seletiva implantado em Porto Alegre

Em 2002, o maior desafio apontado pelos técnicos de Porto Alegre era o de resolver a questão dos catadores avulsos e sucateiros que atuavam nas vias públicas, geralmente, antes da passagem dos veículos da coleta seletiva porta a porta e retiravam o material reciclável de maior valor, restando para a prefeitura coletar e distribuir para as Unidades de Triagem os materiais de menor valor de mercado. Com isso, a administração municipal temia pela desmotivação das cooperativas de triagem.

A equipe de Porto Alegre estudava a adoção de uma estratégia de criação de Entrepostos de Compra dos materiais recicláveis, onde pudesse ser praticado um preço mais vantajoso que o oferecido pelos sucateiros, para atrair os catadores autônomos. No momento da visita, os sucateiros forneciam os carrinhos aos catadores e ficavam com 50 \% da sua produção.

Durante a visita, foi passada a informação sobre o projeto para implantação de uma usina de beneficiamento de plástico, com objetivo de agregar maior valor ao trabalho realizado nas unidades de triagem. Esta usina iria atender a todas as Unidades de Triagem implantadas.

A gerência responsável pela operação da coleta seletiva era, também, responsável por todas as atividades de coleta do sistema de limpeza urbana do município e constatou-se a necessidade de redistribuir atribuições a partir da criação de gerência exclusiva para a coleta seletiva.

\subsubsection{Coleta Seletiva em Florianópolis - SC}

O município de Florianópolis possuía população de 350.000 hab e a coleta seletiva era operada pela Companhia de Melhoramentos da Capital-COMCAP.

O sistema de coleta regular de resíduos sólidos domiciliares operava com 350 a 400t/dia, sendo com freqüência diária nas zonas comerciais e alternada em bairros periféricos.

Durante o verão, devido ao grande fluxo de turistas, o sistema sofria algumas adequações.

A seguir tem-se apresentadas as informações obtidas: 
- Modalidade de coleta seletiva implantada -

Em 2002, o município de Florianópolis operava, exclusivamente, com a modalidade de coleta seletiva porta a porta.

A Coleta Seletiva Porta a Porta, por sua vez, foi iniciada em 1994, na área central do município, tendo crescido gradativamente para os bairros do entorno, alcançando, em 2002, $100 \%$ da área do município.

A coleta seletiva no município foi implantada em 1986, por meio de postos de entrega voluntária-PEVs, os quais foram, posteriormente, desativados devido à ocorrência de ações de vandalismo. Existiam planos para sua reativação, com um novo modelo de recipiente coletor.

- Operação do programa de coleta seletiva

O gerenciamento da operação da coleta seletiva estava centralizado na gerência responsável por todas as atividades de coleta e transporte da COMCAP, sendo que o pessoal envolvido na atividade era funcionário dessa empresa.

A coleta seletiva porta a porta operava em dias e horários diferenciados, em relação à coleta regular e acreditava-se que esta estratégia contribuía para menor presença de matéria orgânica e outros rejeitos no material reciclável coletado. A programação visual diferenciada dos veículos e a realização da coleta seletiva em períodos diurnos também contribuíam favoravelmente para esse mesmo propósito.

Adotavam como critério que o percentual de rejeitos pós-triagem do material reciclável, obtido na coleta seletiva porta a porta, deveria ser da ordem de 10 a $15 \%$. Resíduos sólidos coletados seletivamente com percentuais de rejeito acima de 30\% não poderiam ser considerados como oriundos de coleta seletiva.

Para manter este padrão, a equipe técnica responsável pela coleta seletiva de Florianópolis, adotava a estratégia de não coletar resíduos sólidos que não estivessem adequadamente separados no dia especificado para coleta.

A partir do acionamento ou reclamação pelo cidadão, via linha telefônica específica, quanto à não realização da coleta dos resíduos sólidos, novo esclarecimento e orientação sobre a forma adequada de separação dos resíduos sólidos para apresentação à coleta seletiva era realizado. 
Eram utilizados caminhões tipo baú (figura 18) e coletores compactadores (figura 19) para realizar a coleta seletiva porta a porta.

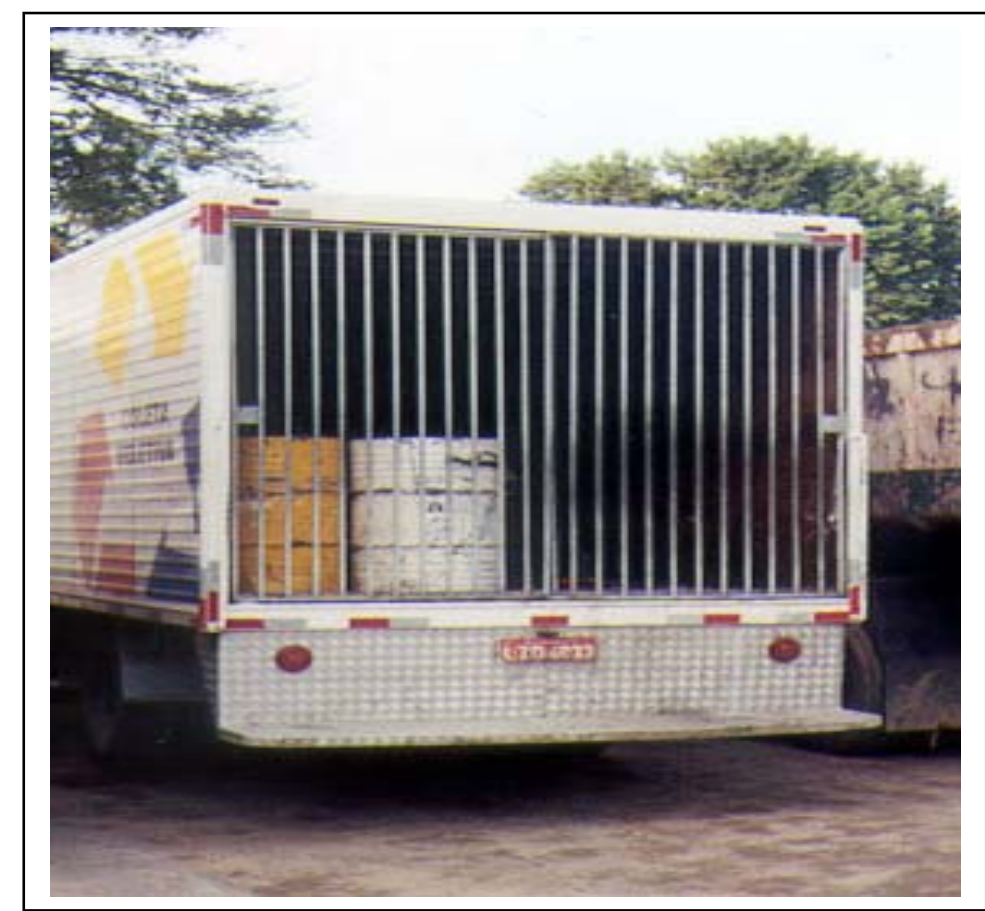

Figura 18 - Vista do veículo baú utilizado para Coleta Seletiva, Florianópolis, 2002.

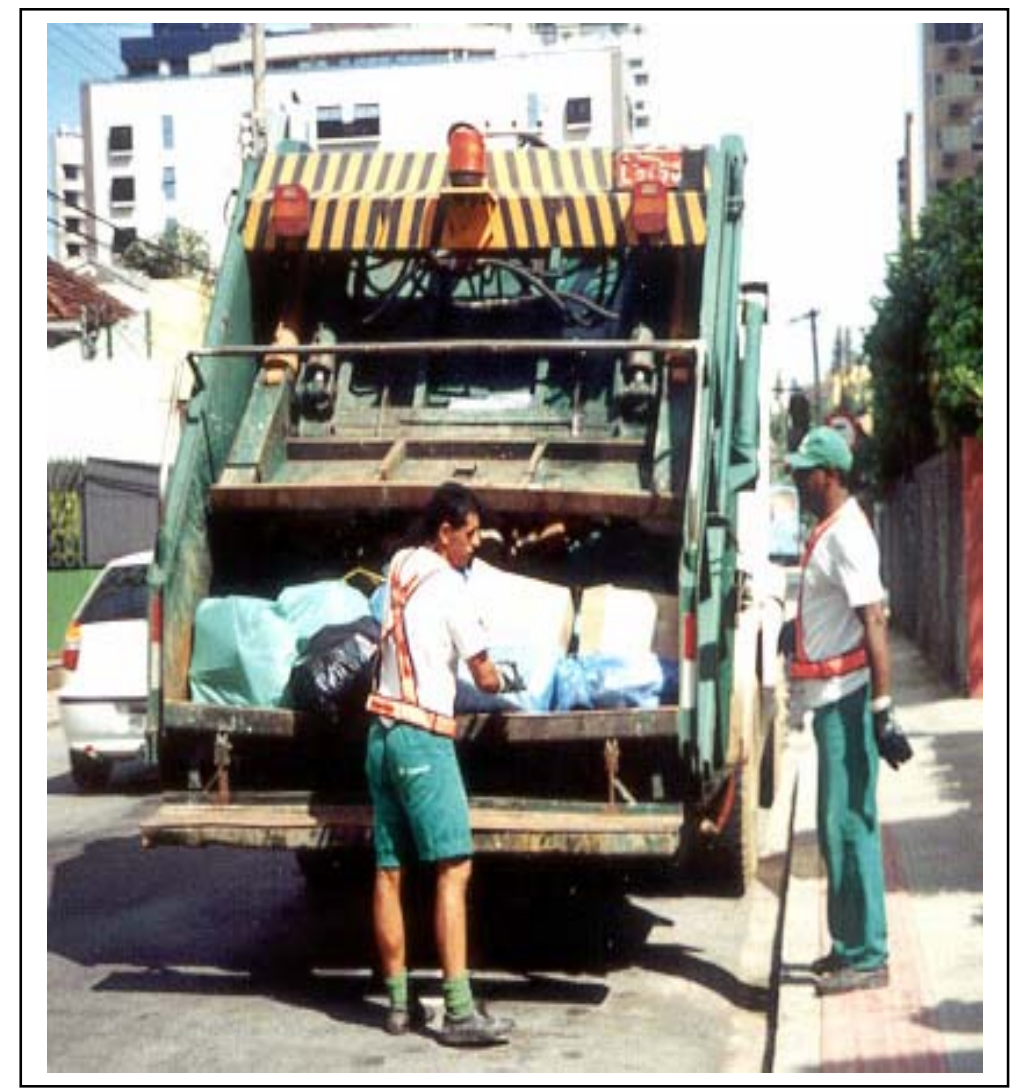


Figura 19 - Operação da Coleta Seletiva, Florianópolis, 2002.

A maior facilidade e capacidade de carga e conseqüente redução do esforço físico do coletor, bem como o fato da descarga ser automatizada, eram vantagens na utilização do caminhão coletor compactador. Como desvantagem, havia o fato de, algumas vezes, os materiais perfuro-cortantantes, como vidros quebrados, aderirem a outros materiais recicláveis, como o papelão, gerando dificuldades e acidentes na operação de triagem.

A guarnição de coleta, a qual foi possível contatar, apresentava-se motivada e consciente quanto à importância do seu trabalho.

O pessoal trabalhava uniformizado e com EPI's, sendo o uniforme da guarnição da coleta seletiva diferenciado (figura 20).

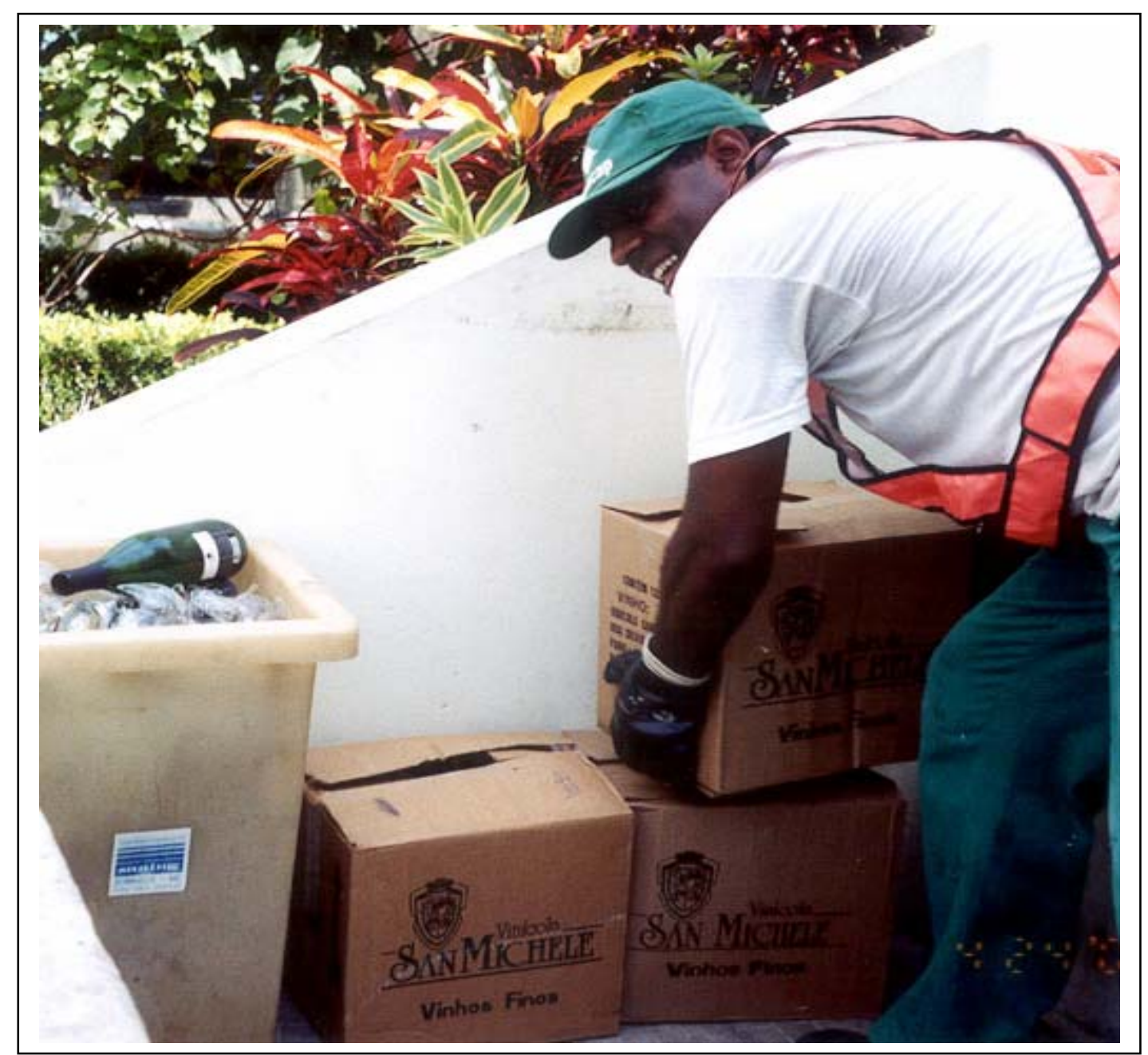


Figura 20 - Operação da Coleta Seletiva, Florianópolis, 2002.

Todo material reciclável coletado pela coleta seletiva porta a porta era levado ao Centro de Transferência de Resíduos Sólidos-CETRE para pesagem e posterior encaminhamento à triagem e beneficiamento. No CETRE também funcionava a unidade de transbordo que atende aos serviços de coleta regular de resíduos sólidos urbanos que, segundo a COMCAP, coletava principalmente a parcela dos resíduos sólidos orgânicos.

A partir de parcerias firmadas com associações de recicladores, a COMCAP estava repassando todo material reciclável coletado pela coleta seletiva porta a porta para os catadores organizados.

Na oportunidade, visitou-se a Associação de Recicladores Esperança-ARESP, formada, basicamente, por moradores do assentamento da prefeitura conhecido como Chico Mendes, que possuía 34 associados e utilizava espaço e equipamentos cedidos pela COMCAP, dentro do próprio CETRE, para realizar a triagem, beneficiamento e comercialização dos materiais recicláveis.

A ação desenvolvida para a região do centro, onde existia muito comércio e a presença de catadores, era diferenciada. Com apoio da prefeitura local, foi organizada, em 1999, uma entidade conhecida como papeleiros, que trabalha com a coleta e comercialização de papel e papelão na região central da cidade.

A produção dos papeleiros era comercializada diretamente com o aparista, sendo que a COMCAP monitorava os preços praticados para garantir melhor renda a esses trabalhadores. O comprador instalava contêineres metálicos para o acondicionamento do papelão, após a triagem, no próprio local de trabalho dos catadores que, no momento da visita, estavam instalados embaixo de um viaduto (figura 21 e 22).

A prefeitura viabilizou, ainda, uma creche para os filhos dos catadores da Organização dos Papeleiros, que funcionava em horário compatível com a atividade que realizam, e não permitia a presença de crianças na catação dos resíduos sólidos recicláveis. Cada catador trazia o material coletado, que era pesado, e recebia individualmente, segundo a sua produção.

A equipe da COMCAP atribuía à criação da organização dos papeleiros a solução do conflito existente entre catadores e sucateiros (atravessadores), tendo como 
conseqüência a melhoria dos preços da comercialização de materiais recicláveis. Dessa forma os catadores continuavam ocupando seu espaço nas ruas do centro de Florianópolis, evitando a migração de outros catadores para o local.

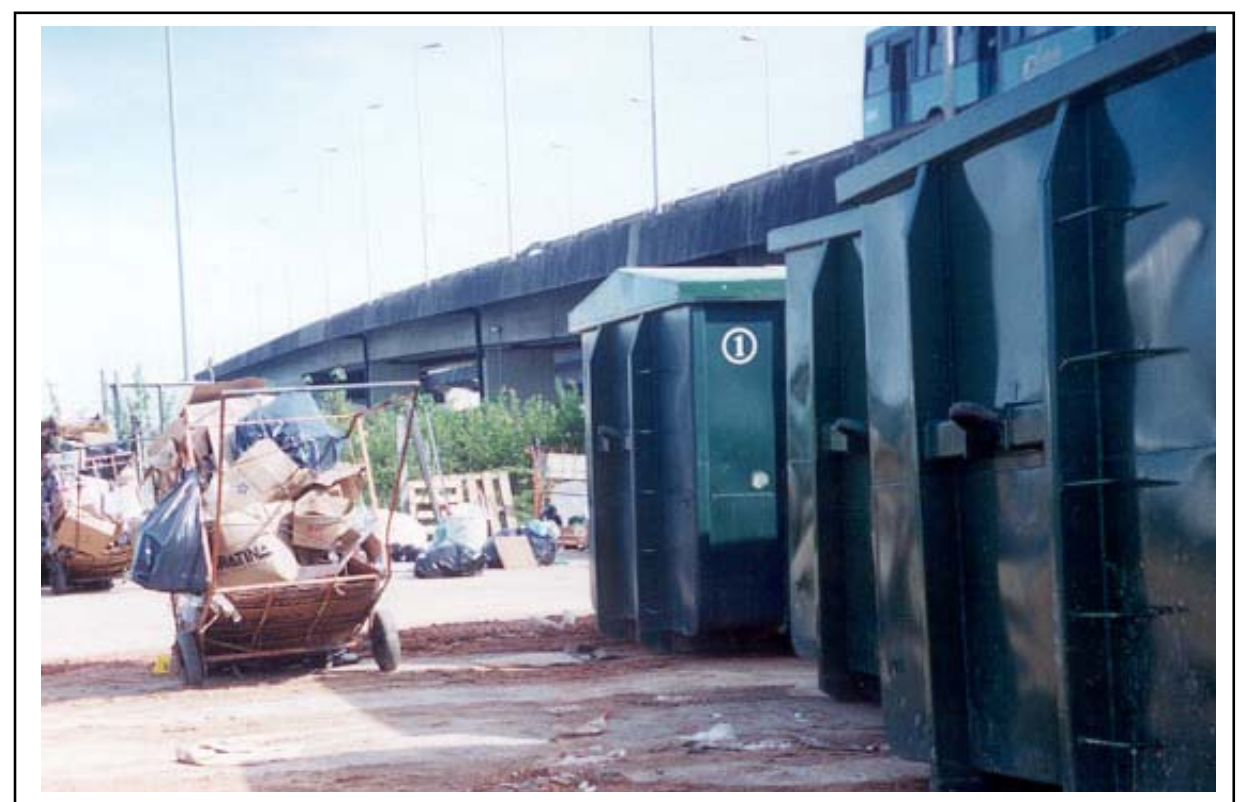

Figura 21 - Vista do deposito de reciclaveis dos papeleiros, Florianopolis, 2002.

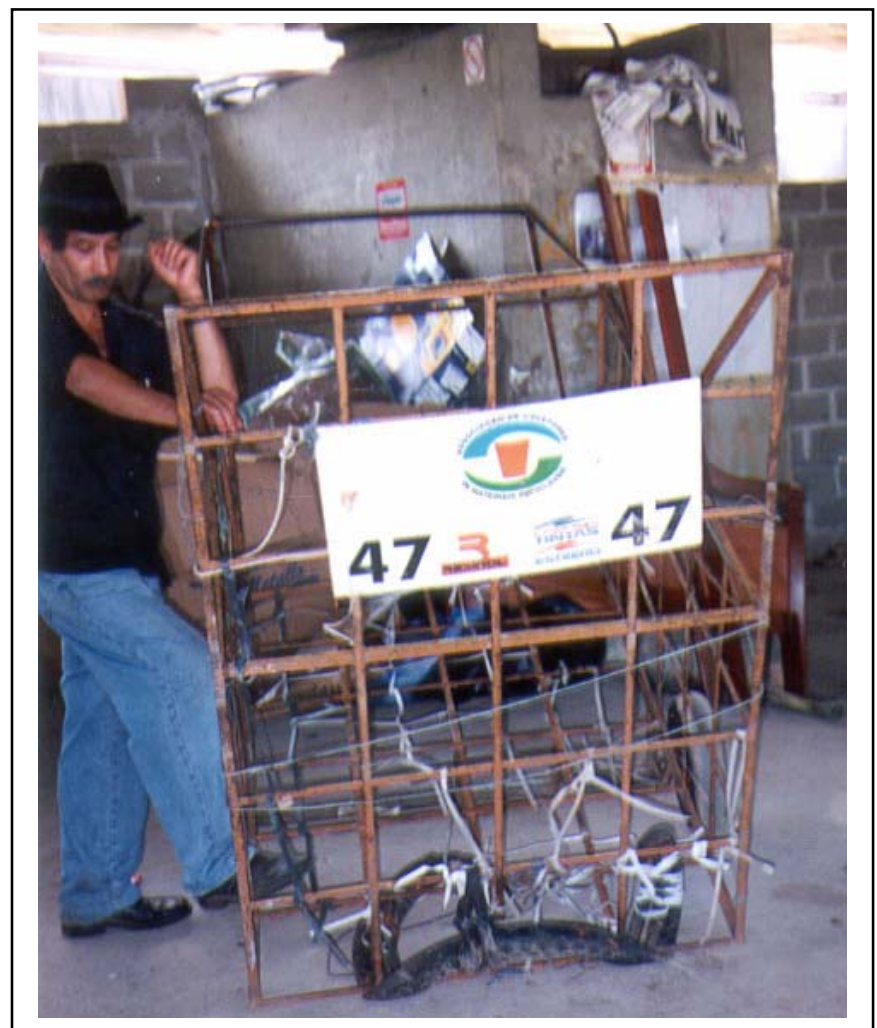

Figura 22 - Carrinho para coleta de recicláveis dos papeleiros, Florianópolis, 2002. 
- Aspectos da participação social no programa de coleta seletiva

De acordo com informações coletadas, na implantação do programa de coleta seletiva (1994) foi realizada uma grande campanha de mobilização de massa, não sendo possível, na época, realizar abordagens individuais às residências e condomínios.

Os técnicos da COMCAP acreditavam que a abordagem individual teria sido a estratégia ideal de atuação para sensibilizar a população para a participação na coleta seletiva de resíduos.

Como forma permanente de divulgação, as guarnições de coleta dispunham de folhetos com informações sobre a coleta seletiva nas cabines dos caminhões para distribuirem aos munícipes interessados.

Não havia dados levantados sobre a participação da população, mas estimava-se que a recuperação, através da coleta seletiva, chegasse a cerca de $6 \%$ dos resíduos sólidos urbanos que seriam destinados à coleta regular do sistema municipal de limpeza pública.

De acordo com o pessoal da COMCAP, a produção da coleta seletiva vinha caindo gradativamente nos últimos dois anos, necessitando de investimento em ações de sensibilização junto aos condomínios, devido às constantes ocorrências de irregularidades quanto à separação e apresentação dos resíduos sólidos para a coleta seletiva.

A entidade responsável pela triagem e beneficiamento dos materiais recicláveis, Associação de Recicladores Esperança-ARESP, contava com o apoio do Centro Federal de Educação Tecnológica de Santa Catarina para a capacitação do pessoal envolvido no trabalho.

No CETRE funcionava, também, um Centro de Educação Ambiental que recebia visitas de escolas e outros interessados.

- Aspectos de custos e produção do programa de coleta seletiva

$\mathrm{Na}$ operação do programa de coleta seletiva, contavam com servidores efetivos da COMCAP que trabalhavam num regime de 40 horas semanais. 
A coleta era realizada, semanalmente, por 4 caminhões do tipo baú, com capacidade de $20 \mathrm{~m}^{3}$, e 1 coletor compactador, com capacidade de $12 \mathrm{~m}^{3}$, que operavam com 2 a 3 ajudantes, conforme o bairro e o veículo.

Os veículos coletores compactadores, com capacidade de $12 \mathrm{~m}^{3}$, operavam com compactação máxima de 2 para 1.

Os técnicos da Prefeitura Municipal de Florianópolis informaram que o peso médio da carga de materiais inorgânicos (resíduos sólidos secos) coletados seletivamente era de 1800 a 2000 kg, para os dois tipos de veículos utilizados. Valores superiores a 2500 kg/viagem indicariam presença elevada de resíduos sólidos orgânicos junto ao material reciclável.

A associação de papeleiros contava, na ocasião da visita, com 80 associados, sendo 40 fixos e 40 itinerantes, os quais coletavam cerca de 157/toneladas/mês, alferindo renda média entre R\$ 500 e R\$ 600,00. No entanto, durante a visita técnica não foi possível obter os custos do programa de coleta seletiva de Florianópolis.

- Avaliação do programa de coleta seletiva implantado em Florianópolis

Em 2002, os maiores desafios verificados no programa de coleta seletiva de Florianópolis eram: implementação de ações sistemáticas de sensibilização e mobilização da população e registro e análise de informações sobre seu desempenho. Durante a visita, constatou-se que, após o lançamento ocorrido em 1994, não havia sido realizada nova campanha de divulgação do programa por meio de veículos de comunicação de massa para e informação sobre a coleta seletiva. No entanto, possuíam folhetos explicativos sobre o assunto para distribuição aos interessados (anexo 7).

As deficiências de registro e análise de dados eram reflexos da inexistência de equipe específica para gerenciar a coleta seletiva. Os técnicos, contatados na COMCAP, acreditavam que seria mais adequada a criação de uma gerência para operar, exclusivamente, a coleta seletiva. Esta gerência deveria contar com efetivo mínimo de: 1 gerente operacional, 1 fiscal de coleta e 2 educadores ambientais para realizar o trabalho de informação aos usuários e atendimento às demandas, principlamente, de condomínios.

Não foram verificados conflitos com catadores autônomos. 


\subsubsection{Coleta Seletiva de Santo André - SP}

Na ocasião da visita técnica, o município de Santo André contava com 648.000 hab e o sistema de coleta regular de resíduos sólidos domiciliares operava com 570 t/dia, atendendo basicamente à população com coleta diária em zonas comerciais e coleta alternada em bairros periféricos.

A seguir tem-se apresentadas as informações obtidas:

- Modalidades de coleta seletiva

O município de Santo André opera com as modalidades de coleta seletiva porta a porta e por meio de PEVs.

A coleta seletiva porta a porta foi iniciada em 1997, a partir das escolas, tendo crescido gradativamente para os bairros do entorno, atingindo, em 2002, 100\% de cobertura no município.

- Operação do programa de coleta seletiva

A empresa municipal Serviço Municipal de Saneamento Ambiental de Santo AndréSEMASA era a responsável pelo gerenciamento do sistema de limpeza urbana do município.

A coleta seletiva porta a porta era operada por empresa contratada, sob a supervisão da SEMASA, que utilizava os mesmos veículos coletores compactadores da coleta regular de resíduos sólidos urbanos com a instalação de uma faixa informativa.

Em 2002, a freqüência da coleta seletiva porta a porta era realizada duas vezes por semana, sendo que acontecia no mesmo horário e em dias diferentes do estabelecido para a coleta regular. Assim, nas áreas onde havia sistema viário que permitia o acesso de caminhões, a população era atendida com 5 dias de coleta por semana: 3 dias de coleta regular (resíduos orgânicos e outros) e 2 dias de coleta seletiva porta a porta.

Devido à adequação de custo e frota de veículos, houve diversos ajustes na freqüência de coleta, até chegarem ao sistema que se encontrava em funcionamento em 2002. Em 1999, operavam com a freqüência de 6 dias por semana de coleta regular (resíduos orgânicos e outros) e 2 dias de coleta seletiva porta a porta. A partir 
de 2001, estavam operando com 4 dias por semana de coleta regular (resíduos orgânicos e outros) e 2 dias de coleta seletiva porta a porta.

Da mesma forma que nos outros municípios visitados, adotavam a estratégia operacional de não coletar os resíduos sólidos quando não estivessem adequadamente separados.

A partir da reclamação ou solicitação do cidadão, via linha telefônica específica, era feita nova orientação, quanto ao correto procedimento para separação dos resíduos sólidos. O sistema de registro de reclamações ou solicitações dos cidadãos era totalmente informatizado, sendo as demandas classificadas por códigos e encaminhadas on line para o setor responsável para análise e resposta. Dessa forma, era possível detectar, rapidamente, os locais com problemas para intervenção.

Todo o sistema de coleta de resíduos sólidos urbanos, de responsabilidade do SEMASA, era monitorado via sistema de informação geográfica. A partir de equipamentos instalados nos caminhões de coleta para seu rastreamento, os roteiros de coleta ficavam totalmente registrados em mapas digitais nos quais constavam o arruamento do município. Informações cadastrais relativas ao efetivo de pessoal, registro de data, hora de início e fim da coleta, hora de descarregamento, peso líquido coletado, distâncias pontuais de coleta, velocidades, entre outras, eram informações também obtidas pelo sistema.

A triagem dos recicláveis era feita a partir de parcerias com organizações de trabalhadores autônomos, sendo que a administração municipal de Santo André possuía Programa de Incubadoras de Cooperativas, em que estava inserida a reciclagem. Em 2002, a triagem dos materiais recicláveis estava sendo realizada por 2 cooperativas instaladas junto ao aterro sanitário.

Os postos de entrega voluntária funcionavam de forma integrada ao recebimento de entulhos, resíduos volumosos e demais materiais inservíveis, em locais conhecidos como Estações de Coleta Seletiva.

O SEMASA disponibilizava, ainda, um caminhão tipo baú para coletar grandes quantidades de materiais recicláveis, mediante solicitação prévia do interessado, segundo agendamento da coleta.

- Aspectos de custos e produção do programa de coleta seletiva 
Na coleta estavam sendo utilizados veículos coletores compactadores de $15 \mathrm{~m}^{3}$, com guarnição de 1 motorista e 3 a 4 ajudantes, operado de forma integrada à coleta regular (figura 23).

O peso médio das cargas de materiais recicláveis coletados seletivamente era de 2000 a $3000 \mathrm{~kg}$ por viagem, para tais equipamentos compactadores.

Os serviços de coleta em funcionamento operavam com 900 t/dia de resíduos sólidos urbanos, 650t/dia de resíduos sólidos domiciliares e 30 a 35t/dia de material reciclável coletado pela coleta seletiva porta a porta.

No sistema de coleta adotado por Santo André, o valor pago à empresa contratada pelo serviço de coleta de materiais recicláveis era o mesmo da coleta regular, cujo valor era de $\mathrm{R} \$ 43,30 / \mathrm{t}$.

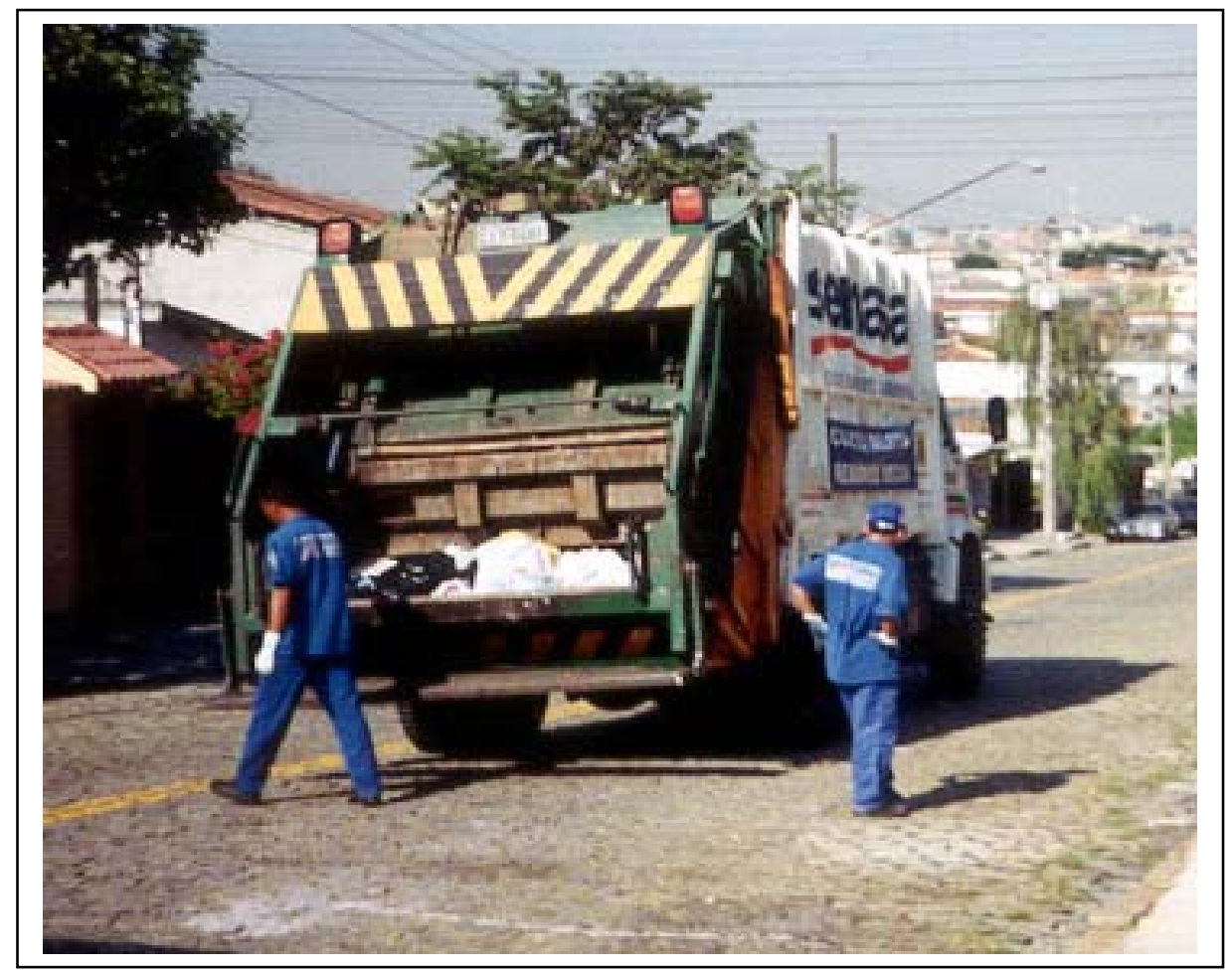

Figura 23 - Operação da coleta seletiva porta a porta, Santo André, 2002.

- Aspectos da participação social no programa de coleta seletiva

A questão da divulgação do programa e sensibilização da população quanto à coleta seletiva estava a cargo da coordenação de comunicação social do SEMASA, a qual adotava como estratégias de convencimento da população: a qualidade de vida, a melhoria da cidade e a inclusão social. 
A coordenação de comunicação social informou que, em 1999, quando a coleta seletiva passou a abranger 60\% do município, foi realizado investimento de $\mathrm{R} \$$ 600.000,00 em divulgação em massa na mídia. Em 2001, houve novo investimento da ordem de R\$200.000,00. Como Santo André possuía 150.000 domicílios, tais valores representaram investimentos de $\mathrm{R} \$ 4,00$ / domicílio, em 1999, e de R\$1,33/ domicílio, em 2001.

Devido a diversos ajustes ocorridos nas freqüências da coleta regular e seletiva, o investimento em mídia foi estratégico para informar à população local sobre o funcionamento da coleta seletiva porta a porta, contribuindo para os resultados atuais de participação social.

O SEMASA realizava pesquisas periódicas para conhecer e avaliar a opinião da população sobre a coleta seletiva. Em 2002, registravam a adesão de 30 a 35\% da população ao programa implantado.

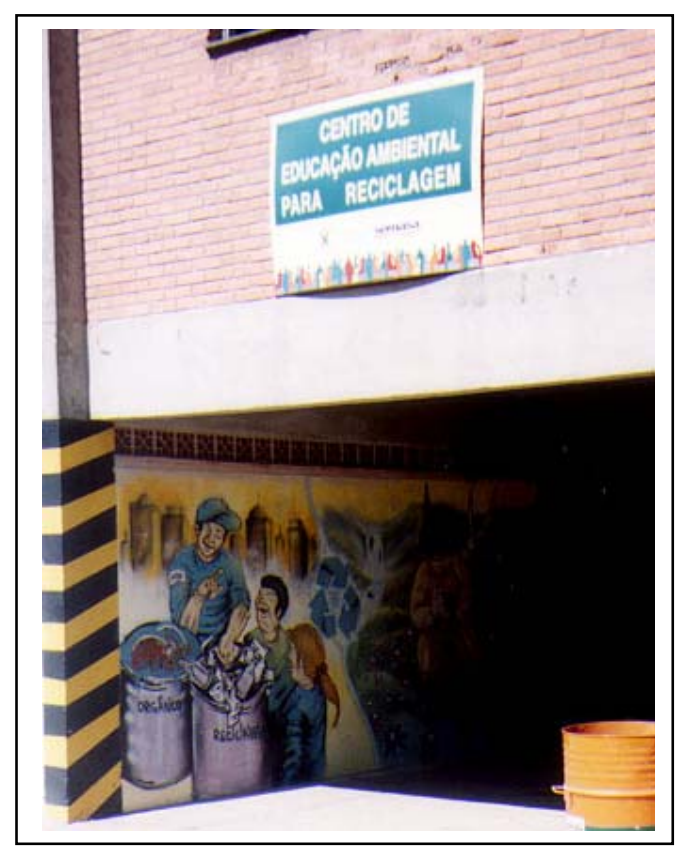

Figura 24 - Vista do Centro de Educação Ambiental, Santo André, 2002.

- Avaliação do programa de coleta seletiva implantado em Santo André

O sistema de registro de informações implantado era bastante moderno e permitia apurar, de forma satisfatória, os dados do programa de coleta seletiva, os quais, por sua vez, poderiam ser melhor trabalhados e divulgados na forma de indicadores. $\mathrm{O}$ controle apurado do teor de matéria orgânica presente nos resíduos sólidos coletados 
pela coleta seletiva porta a porta seria de fundamental importância para aferir se a população estava separando adequadamente os seus resíduos sólidos.

A alternativa operacional adotada por Santo André para realizar a coleta seletiva porta a porta resultava em menores custos e maior complexidade de operação.

Operava-se com equipamentos de coleta semelhantes para coletar materiais de densidades e características diferentes, com velocidades de coleta diferentes, o que tornava complexa a manutenção da regularidade dos horários de coleta informados à população, com reflexos negativos no sistema de limpeza urbana.

Não foi possível verificar a influência de catadores autônomos no programa de coleta seletiva visitado, mas técnicos do SEMASA informaram que esses existiam e que atuavam, principalmente à noite, nos roteiros da coleta seletiva porta a porta, e que estavam sendo cadastrados.

Para o SEMASA, a ação destes catadores autônomos representava uma espécie de coleta seletiva porta a porta virtual, mais eficiente que a coleta seletiva porta a porta operada pelo poder público local. Tal fato precisava ser conhecido e avaliado para permitir a análise real dos resultados do programa implantado.

\subsubsection{Coleta Seletiva em Vitória - ES}

Por ser uma ilha com apenas $81 \mathrm{~km}^{2}$ de área total, o município de Vitória sempre enfrentou dificuldades em alocar áreas para destinação final de seus resíduos sólidos, que fossem sanitária e ambientalmente compatíveis com tal finalidade.

Ao longo dos anos, os resíduos sólidos urbanos de Vitória foram lançados a céu aberto, em áreas alagadas, com presença de catadores, porque o interesse era aterrar tais regiões da ilha para futura ocupação urbana. Este ciclo foi interrompido com a desativação do lixão de São Pedro e o início das operações da Unidade de Triagem e Compostagem de Vitória-UTCV, em 1991, para onde os resíduos sólidos de Vitória passaram a ser destinados.

Parte dos catadores do lixão de São Pedro se organizaram em um sindicato e passaram a trabalhar na operação da UTCV.

No período de 1991 a 1996, os rejeitos da UTCV eram dispostos em área anexa à unidade de triagem, porque o município ainda não dispunha da infra-estrutura de um aterro sanitário. 
A partir de 1996, com a terceirização de serviços do sistema de limpeza pública, o município passou a destinar a parcela dos resíduos sólidos urbanos não recuperados na UTCV para aterros sanitários particulares situados em outros municípios.

Em 2002, o município de Vitória, então com população em torno de de 292.300 hab, coletava e destinava mensalmente a UTCV cerca de 8.000 toneladas de resíduos sólidos urbanos, dos quais $70 \%$ era encaminhado para recuperação como material reciclável após triagem. Cerca de 350 toneladas de material reciclável eram recuperadas mensalmente, além da produção de aproximadamente 80 toneladas de composto orgânico.

Ao longo da década de 90 foram desenvolvidos pela Prefeitura de Vitória diversos programas de coleta seletiva, sendo a experiência mais significativa a iniciada a partir de 1998, que incluía as modalidades de coleta seletiva por meio de postos de entrega voluntária-PEVs e de Coleta Seletiva por Organizações de Trabalhadores Autônomos da Reciclagem.

Em 2002, a equipe técnica envolvida no processo havia detectado diversos problemas na coleta seletiva por meio de PEVs, que contribuíram negativamente para o seu desempenho. Além dos reduzidos investimentos em divulgação e mobilização, o recipiente utilizado, em 1998, para armazenamento de materiais recicláveis permitia com facilidade a incidência de furto dos materiais com maior valor de mercado e apresentava dificuldades na operação de recolhimento manual dos recicláveis acumulados (figura 25). Havia, ainda, problemas com o sistema de identificação visual destes recipientes e elevado custo de manutenção, em função de serem fabricados em chapas de aço e necessitarem, freqüentemente, de lavagem e retoques na pintura. 


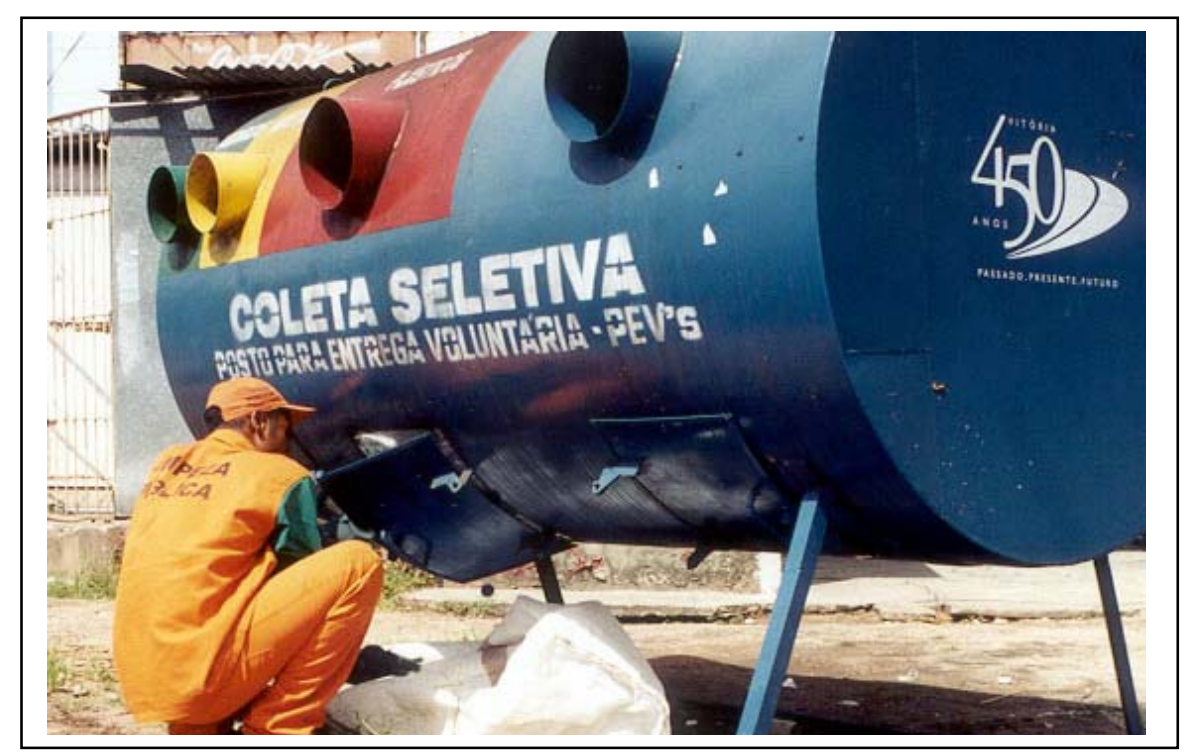

Figura 25 - Equipamento utilizado em Posto de Entrega Voluntária no período de 1998 a 2002, Vitória, 2002.

A coleta seletiva por organizações de trabalhadores autônomos da reciclagem era desenvolvida através da Associação de Catadores de Material Reciclável de VitóriaASCAMARE, tendo sido iniciada com um grupo de 18 catadores e implantada no bairro de Jardim da Penha.

A prefeitura apoiou a implantação da organização com a finalidade de fomentar a inserção social de catadores de rua e pessoas desempregadas que trabalhavam com carrinhos de tração manual na coleta e praticavam a triagem, o enfardamento e a comercialização dos materiais recicláveis.

No plano social, a ASCAMARE tinha o apoio da Pastoral Social da Igreja São Francisco de Assis, que desenvolvia junto às famílias dos catadores um trabalho de catequese, educação, higiene, além da distribuição de cestas básicas.

Os técnicos envolvidos com o projeto relataram que, em sua fase inicial, os moradores dos bairros da área de atuação dos catadores da ASCAMARE passaram a distinguir os mesmos como trabalhadores organizados, em relação aos catadores avulsos, que ainda estão ligados a sucateiros e operando de forma desorganizada. Tal fato era atribuído, principalmente, à utilização de uniformes e veículos padronizados, em bom estado de conservação, e à sua divulgação pela mídia, de forma espontânea. 
O resultado imediato foi a melhoria do poder aquisitivo dos catadores, incluindo vantagens, como prêmio por produção, utilizado como fator de estímulo ao trabalho. Com o passar do tempo, o galpão também passou a contar com telefone para recebimento das solicitações de coleta de condomínios, residências etc, da doação de material reciclável e do desenvolvimento da coleta seletiva.

Em outubro de 2001, devido a problemas com a locação do galpão, a sede operacional da ASCAMARE foi transferida para o Bairro República, onde funcionava de forma precária, em 2002. O pessoal da comunidade não conhecia o trabalho da organização; a estrutura no novo galpão não estava adequada ao trabalho realizado e as distâncias a serem percorridas pelos catadores até as regiões onde rotineiramente atuavam ficaram maiores.

Com base na experiência acumulada, a partir de setembro de 2002, a prefeitura iniciou a implementação da etapa de ampliação e modernização da coleta seletiva no município, que passou a ter, de forma simultânea, 3 modalidades de coleta seletiva: por meio de PEVs, porta a porta e por organizações de trabalhadores autônomos da reciclagem.

A expectativa da equipe técnica envolvida no projeto era de que as 3 modalidades de coleta seletiva não iriam concorrer entre si no estágio em que se encontrava o município em 2002, existindo, portanto, espaço para serem trabalhadas simultaneamente. A equipe acreditava que as 3 modalidades se complementariam, ampliando os resultados.

No planejamento da etapa de ampliação, foi utilizada a experiência acumulada na etapa piloto de coleta seletiva por PEVS e de catadores autônomos.

- Modalidades de coleta seletiva

O município de Vitória-ES operava com as modalidades de coleta seletiva por meio de PEVs, catadores autônomos e porta a porta.

- Operação do programa de coleta seletiva 
A Secretaria Municipal de Serviços-SEMURB, em conjunto com a Secretaria Municipal de Meio Ambiente-SEMMAM, eram os órgãos responsáveis pelo gerenciamento do sistema de limpeza pública de Vitória-ES e pela coleta seletiva.

A partir de setembro de 2002, a operação da coleta seletiva por meio de PEVs foi ampliada e modernizada. Os recipientes utilizados para coleta de materiais recicláveis nos PEVs foram substituídos e a quantidade de PEVs quadruplicada. O veículo coletor utilizado passou a contar com equipamento semi-automatizado para a operação de coleta dos recicláveis. (figura 26).

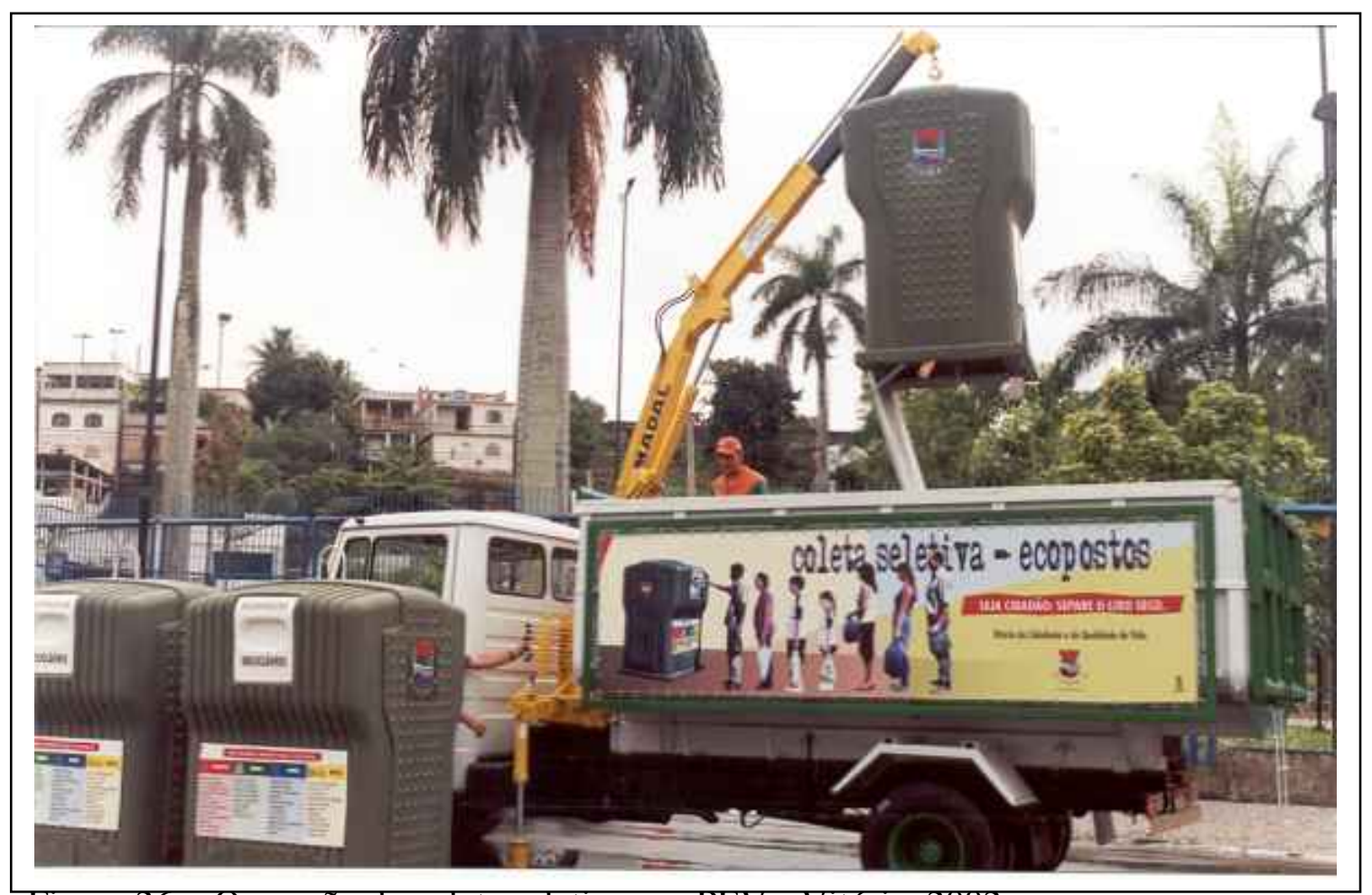

Figura 26 - Operaçáo da coleta seletiva por PEVs, Vitória, 2002.

Em novembro de 2002, passou a funcionar a coleta seletiva porta a porta, a qual utilizava os mesmos coletores compactadores da coleta regular, a partir da instalação de placa informativa na lateral do veículo, com fins de possibilitar a sua identificação pela população.

O município, que operava com coleta regular de segunda a sábado, em todos os bairros de Vitória, substituiu dois dias de coleta regular pela coleta seletiva mantendo os mesmos horários. Assim, o resíduo sólido reciclável (plásticos, papéis, vidros e 
metais) deveria ser separado pela população e apresentado para coleta às terças e quintas-feiras.

Como estratégia de operação de coleta, a guarnição passou a ser composta por 1 motorista, 3 garis coelho e 3 garis coletores. Os garis coelho passavam adiantados cerca de 30 minutos, em relação ao horário de coleta, e realizavam inspeção e seleção dos resíduos à espera da coleta seletiva, com o objetivo de verificar se a segregação estava corretamente efetuada; em caso negativo, os resíduos não eram coletados e ainda um adesivo era afixado no saco plástico, com orientações para uma correta separação. (figuras 27 e 28).

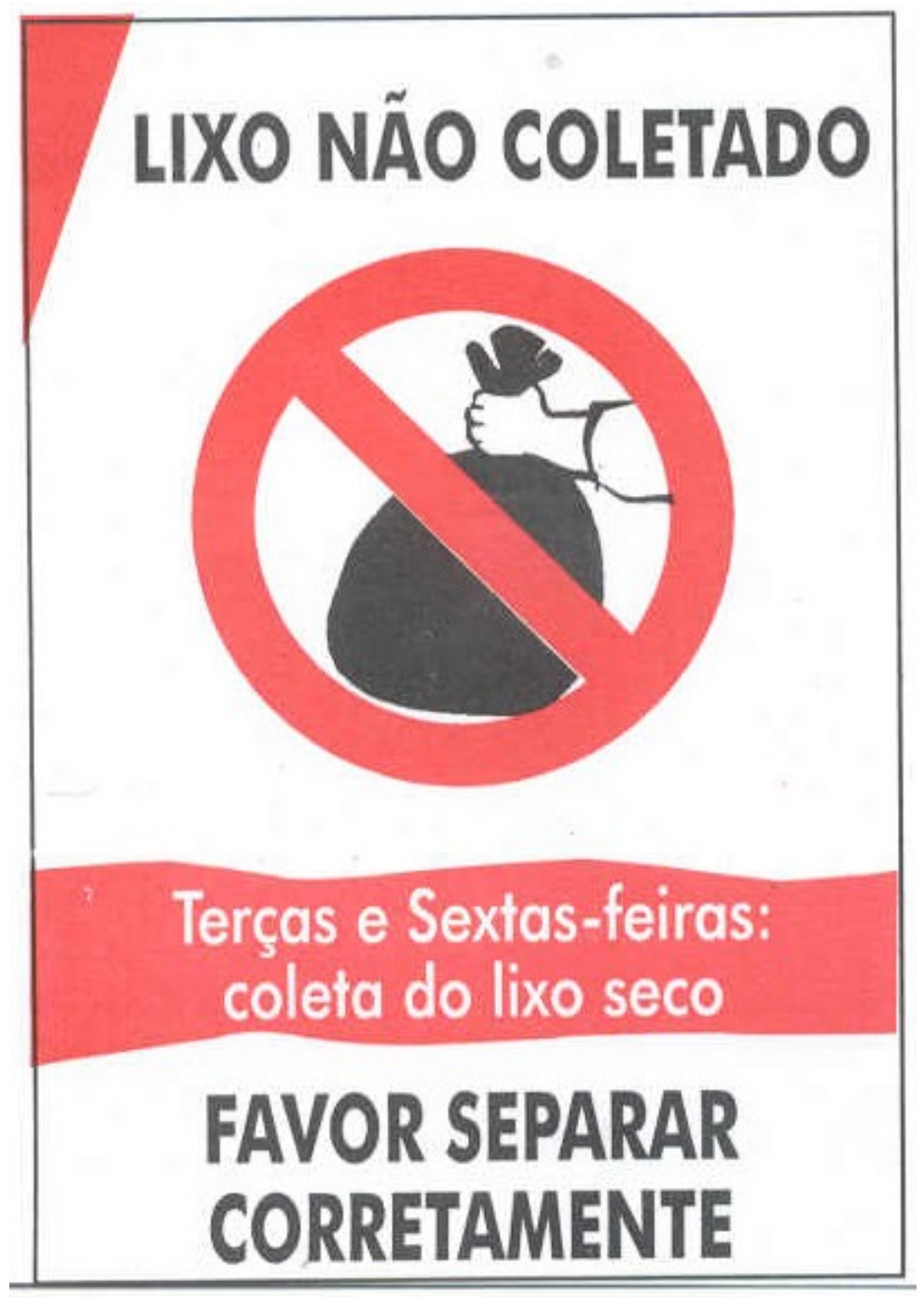

Figura 27 - Adesivo afixado nas sacolas com resíduos rejeitados para coleta seletiva porta a porta, Vitória, 2003. 


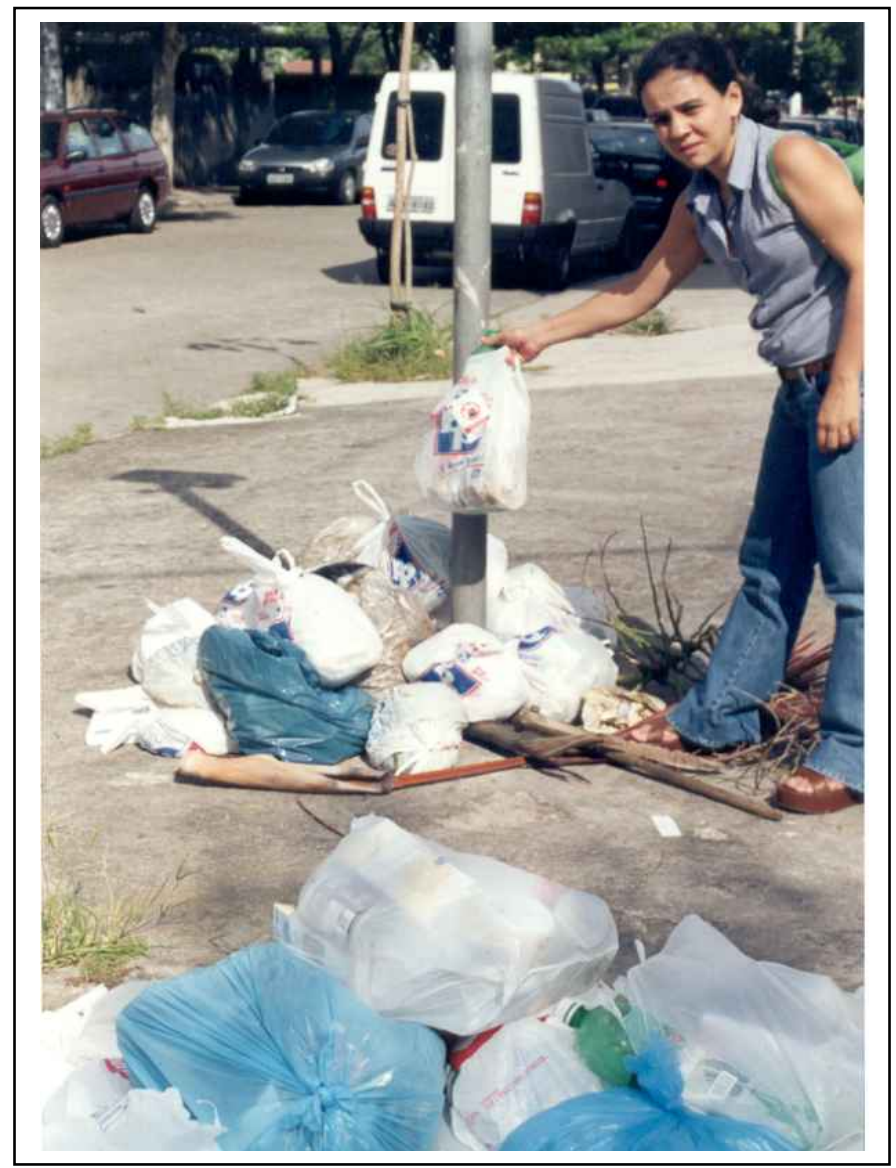

Figura 28 - Resíduos rejeitados pela coleta seletiva porta a porta, Vitória, 2003.

No caso de condomínios e grandes geradores que utilizavam contêineres com rodas para armazenar seus resíduos sólidos, o adesivo era colado nas sacolas que estavam em sua parte superior (figura 29).

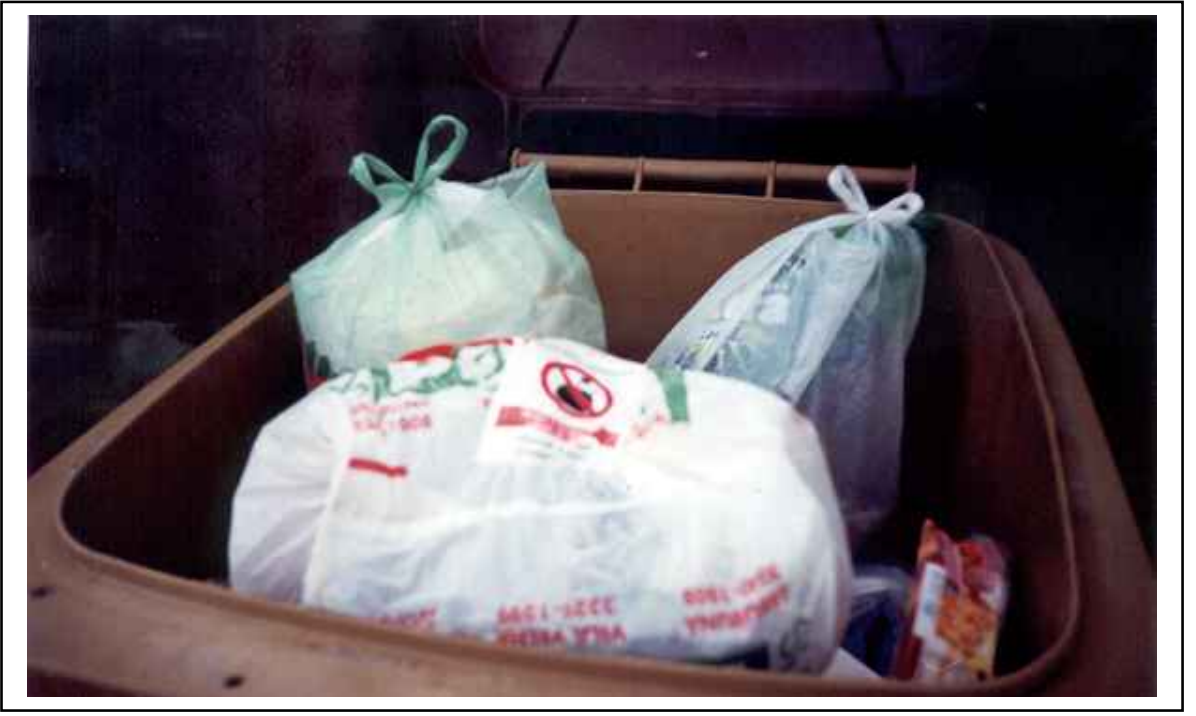


Figura 29 - Resíduos rejeitados pela coleta seletiva porta a porta, Vitória, 2003.

Em paralelo a tal atividade, o supervisor operacional de coleta seletiva acompanhava, diariamente, o serviço realizado pela empresa contratada, registrando ocorrências relativas à operação e à participação da população.

A UTCV era utilizada como base de apoio para as modalidades de coleta seletiva por PEVs e porta a porta, realizando a classificação e enfardamento do material reciclável coletado. Tal atividade era realizada em paralelo ao processamento dos resíduos sólidos urbanos coletados de forma não seletiva.

A UTCV possuía capacidade nominal de processamento da ordem de 320 ton/dia, e estava operando, em 2002, com cerca de 270 ton/dia. Os caminhões coletores de resíduos sólidos chegavam a UTCV e eram pesados na balança rodoviária, antes de serem descarregados.

A estrutura da UTCV contava com um setor específico, responsável por todas as operações de controle de produção e da comercialização dos materiais recicláveis recuperados e do composto orgânico produzido.

Quando em quantidade suficiente para completar a carga de um caminhão, os materiais recicláveis eram leiloados e os recursos arrecadados revertidos ao pagamento da mão-de-obra fornecida pelo sindicato dos catadores.

Para o funcionamento da coleta seletiva por organizações de trabalhadores autônomos da reciclagem, a prefeitura, inicialmente, forneceu a infra-estrutura do galpão, os veículos de tração humana, os uniformes e os EPI's e, posteriormente, restringiu-se a custear o aluguel e os insumos: água e energia elétrica do galpão.

Em 2002, existia uma organização de trabalhadores autônomos implantada e em funcionamento. Estava prevista, no plano plurianual de investimentos do município, a estruturação do trabalho existente e a implantação de novos galpões, a partir da realização de diagnóstico sobre os catadores. Nesse contexto, o material continuaria a ser recolhido, transportado ao galpão de triagem e beneficiamento, classificado e comercializado pelas próprias organizações, sem interferência do poder público.

- Aspectos da participação social no programa de coleta seletiva 
Segundo relato do pessoal da prefeitura, não houve investimentos significativos em ações de mobilização e conscientização ou marketing para a fase da coleta seletiva nos PEVs, implantada em 1998. A equipe envolvida na coordenação do projeto contou, principalmente, com a divulgação espontânea da mídia, sendo que, quando ocorria alguma inserção, eram verificados picos de participação da população no projeto.

A equipe da prefeitura avaliava que, no período de 1998 a 2002, a coleta seletiva por meio de PEVs havia conquistado a participação de um público fiel, que foi, gradativamente, conscientizando-se e adquirindo o hábito de participar, resultando na recuperação média de 5,6 t/mês, sem oscilações significativas, e com índice médio de rejeitos de 13,34\% (SEMMAM 2002).

Para a ampliação do programa de coleta seletiva, em 2002, foi alterada a metodologia adotada na etapa piloto para separação de materiais secos recicláveis entregues nos PEVs. A classificação em 4 tipos de materiais (papel, plástico, vidro e metal) foi substituída pela classificação resíduos sólidos secos e resíduos sólidos úmidos.

Tal alteração foi baseada na existência da UTCV e na necessidade de uniformização de procedimentos, face à implantação da coleta seletiva porta a porta na cidade, ficando definido, no projeto de ampliação, que deveria haver um amplo esclarecimento da população local sobre a questão.

Para dimensionar o programa, a equipe técnica da municipalidade de Vitória adotou, para coleta seletiva por meio de PEVs, o índice de participação inicial de $10 \%$ da população e, para a coleta seletiva porta a porta, a expectativa de $15 \%$ de participação (SEMMAM 2002).

Com a implantação da etapa de ampliação do programa, a partir de setembro de 2002, foi elaborado um Plano de Mobilização e Divulgação a ser implementado pelo Departamento de Educação Ambiental da SEMMAM. Devido a restrições orçamentárias e de pessoal, este plano priorizou a modalidade de coleta seletiva porta a porta.

Em 2002, a prefeitura contratou pesquisa de opinião, na qual 81,5\% dos entrevistados demonstraram disposição em aderir à coleta seletiva. Segundo essa pesquisa, a motivação dos 74,1\% dos votantes em participar da coleta seletiva está na 
preservação do ambiente, seguido por geração de empregos (17,5\%) e melhoria da limpeza $(8,43)$.

Para a coleta seletiva porta a porta, foi contratada uma empresa para realizar o trabalho de sensibilização da população. O pessoal contratado realizou visitas aos estabelecimentos residenciais e comerciais para a divulgação e orientação sobre o programa que seria implantado.

Após a implantação da coleta seletiva porta a porta, foram desenvolvidas, por um período, atividades de monitoramento educativo, acompanhando o veículo de coleta, anotando as residências que não aderiram ao novo sistema para, no dia seguinte, fazer abordagens. Um veículo do tipo van, equipado com caixas de som, fazia a divulgação de orientações sobre o projeto, percorrendo as vias um pouco antes da passagem do caminhão de coleta no caso de Jardim Camburi.

Nos outros bairros envolvidos na coleta seletiva porta a porta, a coleta era noturna, e em alguns trechos acontecia após as 22:00 horas estendendo-se até 1:30 hora da manhã. Nestas regiões o monitoramento acontecia apenas nos pontos mais críticos levantados pelo pessoal da operação.

Tal atividade de monitoramento educativo estendeu-se até 20 de dezembro de 2002, atuando, basicamente, durante o dia, não sendo trabalhados com a mesma intensidade os roteiros de coleta seletiva operados no período noturno.

A partir da avaliação da quantidade e da qualidade do lixo seco coletado calculavam um percentual médio de recuperação de $22,86 \%$, para o roteiro noturno de coleta seletiva porta a porta, e 25,89 \% para o roteiro diurno, em relação ao total do lixo seco produzido nos bairros envolvidos. Tais valores dão uma indicação da participação da população.

Para a coleta seletiva por PEVs, a estratégia inicial de divulgação consistiu, basicamente, na distribuição de material informativo em eventos e pontos estratégicos da cidade e na capacitação de professores para atuarem como agentes multiplicadores. Contaram, também, com o apoio espontâneo da mídia. Em maio de 2003, 8 meses após a implantação, a prefeitura iniciou a veiculação de um comercial sobre a coleta seletiva, em mídia de TV. No entanto, a equipe técnica envolvida nas ações de mobilização foi reduzida devido a cortes orçamentários. 
Em 2003, a equipe técnica de Vitória considerava que a população havia aceitado bem a mudança de prática quanto à separação dos resíduos sólidos: resíduos sólidos secos e úmidos, principalmente, pela maior facilidade de segregação, o que motivaria a participação.

- Aspectos de custos e produção do programa de coleta seletiva

A operação das modalidades de coleta seletiva por meio de PEVs e porta a porta estava a cargo das empresas contratadas para executar os serviços da limpeza urbana do município.

A partir de setembro de 2002, a quantidade de PEVs instalados foi ampliada, passando de 21 unidades, distribuídos em 10 bairros, para 78 unidades, em 35 bairros, espalhados em pontos estratégicos de toda a cidade.

Em 2003, a coleta seletiva por meio de PEVs coletava, em média, 13,0 t de materiais recicláveis a um custo unitário mensal de $\mathrm{R} \$ 748,96$ por tonelada de materiais recicláveis coletados e transportados. Havia, ainda, um custo mensal de investimento a amortizar de $\mathrm{R} \$ 21.148,60$, relativo à aquisição dos recipientes de coleta e ajuste no veículo coletor.

Em maio de 2003, após 8 meses de operação da etapa de ampliação e modernização da coleta seletiva por PEVs, a quantidade de materiais recicláveis coletados era o dobro do sistema anterior, porém representava, ainda, 28\% de uso, pela população, da capacidade instalada, em volume, de armazenamento de recicláveis no conjunto de PEVs em funcionamento.

Este fato foi atribuído ao não desenvolvimento, no início da etapa de ampliação da coleta seletiva por PEVs, da campanha de divulgação na mídia pela prefeitura, pois muitos munícipes ainda desconheciam o sistema.

Nesta mesma época (maio/2003), a ASCAMARE trabalhava com 11 catadores que não utilizam uniformes e EPI’s, e coletavam, ainda, com os carrinhos fornecidos pela prefeitura, totalmente sucateados, produzindo uma média mensal de cerca de 20 toneladas de material reciclável.

Através de acordo contratual, a coleta seletiva porta a porta operava com o mesmo custo unitário por tonelada atribuída à coleta regular. Assim, a operação da coleta 
seletiva porta a porta coletava mensalmente, em média, 92,0 t de recicláveis a um custo de $\mathrm{R} \$ 55,81$ por tonelada de materiais recicláveis coletados e transportados.

A coleta seletiva porta a porta foi implantada em novembro de 2002, período do ano em que ocorrem diversas sazonalidades no município de Vitória com relação à produção de resíduo sólido, como festividades de final de ano, maior fluxo de turistas, devido à temporada de verão, e férias escolares. Tal fato dificultou a avaliação segura, em termos operacionais, dos resultados e comportamento da coleta seletiva porta a porta, em maio de 2003, final do período de acompanhamento para registro de informações para a presente tese.

\section{. Ampliação e Modernização da Coleta Seletiva em Vitória}

Após a implantação da etapa de ampliação e modernização do programa, em setembro de 2002, o mesmo foi monitorado durante 8 meses, até maio de 2003. O monitoramento consistiu na avaliação do cumprimento das metas traçadas e no acompanhamento do seu desempenho rotineiro.

A seguir apresenta-se a situação verificada no período.

\section{.Coleta Seletiva por Postos de Entrega Voluntária}

A meta traçada pela prefeitura era a universalização da modalidade de coleta seletiva por meio de PEVs, sendo que a equipe técnica envolvida adotou o critério de que um cidadão deveria se deslocar, no máximo, 500 metros para encontrar um PEVs onde pudesse depositar o material seco reciclável. Portanto, dimensionou um total de 130 PEVs a serem implantados em todo o município até 2004.

Para instalação dos PEVs, algumas condições mínimas para seleção dos locais foram estabelecidas. A locação dos PEVs no espaço urbano foi precedida de análise da microregião do entorno, no que se refere à existência de unidades escolares, praças, parques, áreas verdes, além de ser considerada a demanda espontânea por parte das comunidades organizadas. A análise locacional das unidades escolares visou, também, ao atendimento das demandas existentes por parte da equipe de Educação Ambiental, que pretendia revitalizar a coleta seletiva nas escolas da rede municipal. 
O lançamento da etapa de ampliação e modernização da coleta seletiva por meio de PEVs ocorreu em setembro de 2002, durante um tradicional evento da cidade, a Feira do Verde (figura 30), e contou com grande apoio da mídia local.

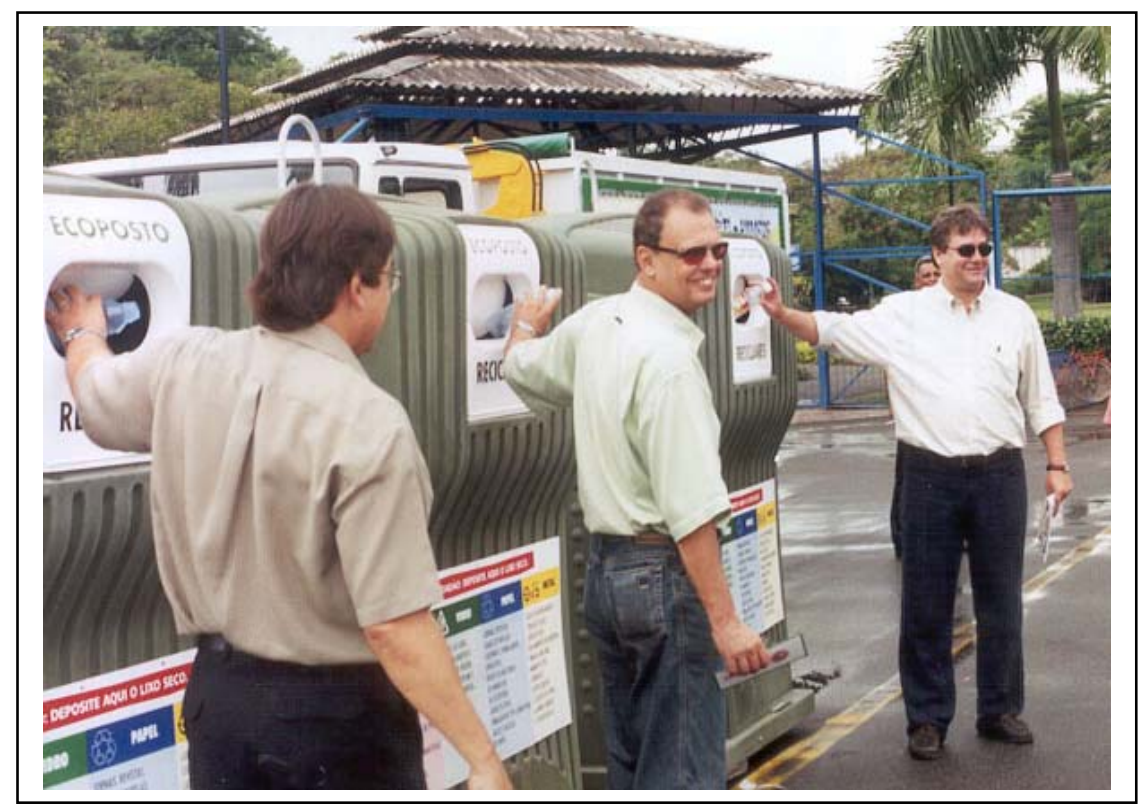

Figura 30 - Lançamento da coleta seletiva por PEVs em Vitória, 2002

Como a coleta era feita de forma automatizada para um grupo de PEVs não foi possível acompanhar o desempenho individual de cada PEV, o que permitiria verificar, também, a adesão da população do seu entorno.

Foi implantada rotina de visitação semanal aos PEVs, em horário anterior ao da coleta, que era noturna. Durante o dia, um técnico realizava a inspeção visual dos PEVs e registrava o nível percentual de preenchimento das caixas coletoras, ou seja, o quanto de sua capacidade volumétrica já havia sido ocupado e, também, a ocorrência de vandalismo e a utilização indevida do equipamento.

A partir dos dados coletados, a equipe técnica da prefeitura elaborava, mensalmente, o ranking dos 10 melhores e 10 piores PEVs, para posterior divulgação.

Cruzando-se os resultados mensais obtidos no ranking com os atributos: classe sócio-econômica, localização, densidade populacional e ocorrência de vandalismo, procedeu-se à análise e discussão dos resultados da coleta seletiva por meio de PEVs para verificar o seu desempenho.

O município de Vitória, dividido em sete regiões administrativas, em função das características semelhantes dos bairros, era a base do planejamento de implantação de novos PEVs e para os controles operacionais municipais. No gráfico 1 é 
apresentada a distribuição dos PEVs, segundo as diversas regiões administrativas da cidade.

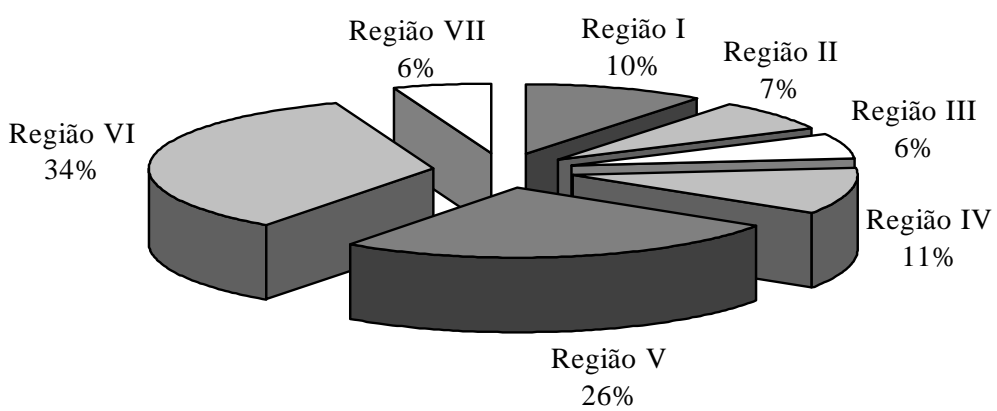

Gráfico 1 - Distribuição percentual de PEVs, segundo região administrativa do município de Vitória, no período de setembro/2002 a maio/2003. Vitória.

Contatou-se que o tempo de existência dos PEVs era fator positivo para o desempenho da coleta seletiva. Verificou-se que dos 62,0\% de PEVs já existentes desde a etapa piloto do programa integravam o grupo dos 10 PEVs de melhor desempenho, enquanto $100 \%$ dos PEVs de pior desempenho estão no grupo dos novos, fato atribuído à internalização do hábito de segregar pela população do entorno (grupo cativo).

Quanto à classe social, verificou-se que, em média, a maior parte dos 10 PEVs de melhor desempenho operacional estavam localizados em bairros classe A (21\%) e B (71\%), enquanto os 10 piores encontravam-se distribuídos indistintamente por todas as classes.

Inicialmente, a expectativa da equipe técnica do município era obter melhor desempenho dos PEVs instalados em regiões de classe sócio-econômica mais elevada, principalmente por este grupo populacional ter o potencial de gerar maior quantidade de resíduos recicláveis, ter maior acesso à informação e educação e, conseqüentemente, maior possibilidade de aderir à coleta seletiva. 
O fato da maioria dos PEVs antigos estarem situados em bairros classe A e B, e dos PEVs que foram instalados a partir de setembro de 2002 também se concentrarem, predominantemente, nessas mesmas classes sócio-econômicas interferiu na apuração dessa expectativa, o que induz à necessidade de maior tempo de monitoramento para se ter informações mais concretas quanto à existência de relação entre a participação e a classe sócio-econômica da população participante.

Quanto à localização, verificou-se que os 10 PEVs de melhor desempenho operacional, geralmente, estavam localizados em praças, conforme apresenta o gráfico 2, e os $10 \mathrm{PEVs} \mathrm{de} \mathrm{pior} \mathrm{desempenho} \mathrm{operacional,} \mathrm{quanto} \mathrm{à} \mathrm{localização,}$ estavam agrupados em vias públicas e outros, conforme apresenta o gráfico 3.

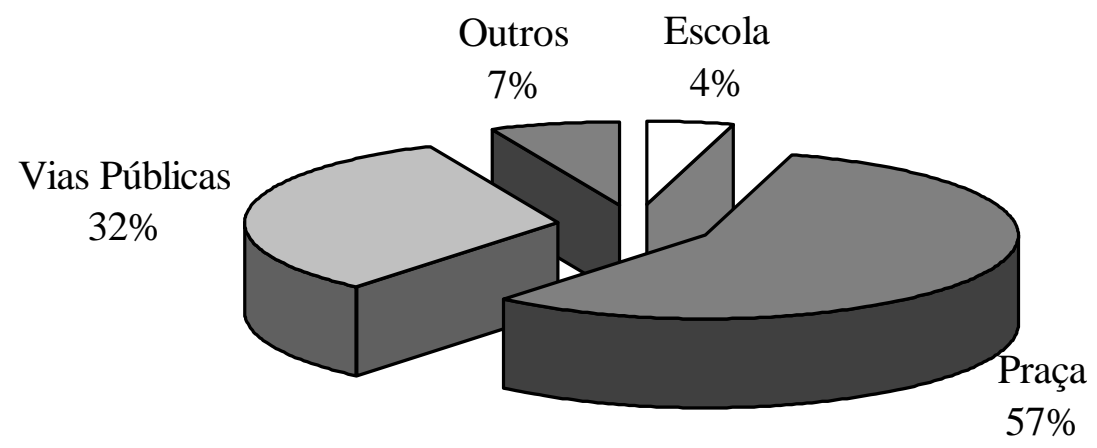

.Gráfico 2 - Distribuição percentual dos 10 PEVs de melhor desempenho operacional, segundo ponto de referencia de sua localizacão, no período de setembro/2002 a maio/2003. Vitória. 


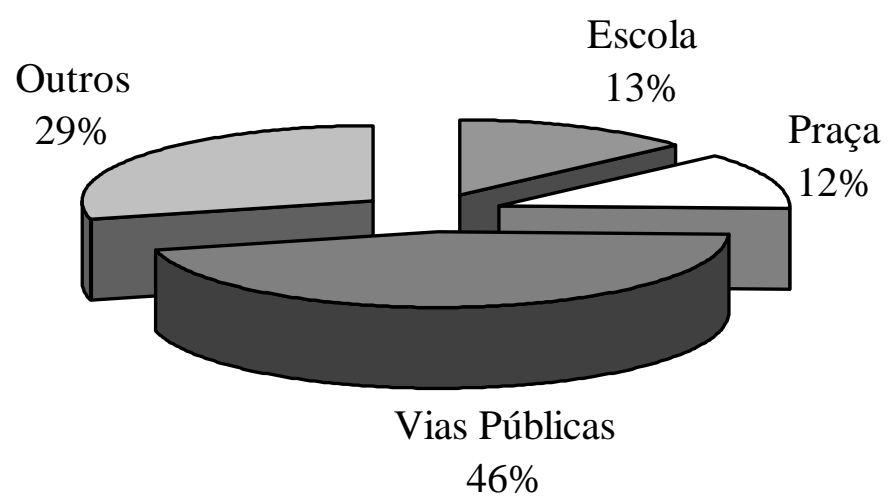

Gráfico 3 - Distribuição percentual dos 10 PEVs de pior desempenho operacional, segundo ponto de referencia de sua localizacão, no período de setembro/2002 a maio/2003. Vitória.

Atribuiu-se ao melhor desempenho dos PEVs localizados em praças o fato de possuírem boa visibilidade, facilidade de acesso, inclusive para se estacionar veículos, e aos de pior desempenho a falta de tais vantagens, além de deficiências no desenvolvimento de ações de mobilização e divulgação.

O critério utilizado pela prefeitura para definir a localização do PEVs foi, para o caso de escolas, a proximidade; no caso de praças, o fato de estar localizado fisicamente em uma praça; no caso de vias públicas, estar localizado em calçadões, calçadas e canteiros centrais de avenidas. Havia outros PEVs localizados próximos a igrejas, supermercados, banca de jornais, estacionamentos e unidades administrativas do governo. Seguindo um critério técnico de projeto, nenhum PEV seria instalado na parte interna de quaisquer estabelecimentos, mas sempre em locais onde o acesso fosse permitido por 24 horas em qualquer dia da semana.

O registro de ocorrências de vandalismo, segundo o ponto de referência de localização do PEV, está apresentado no gráfico 4. 


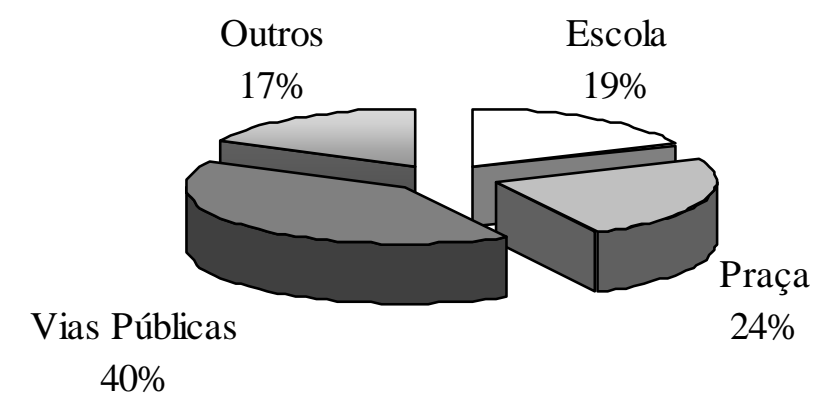

Gráfico 4 - Distribuição percentual das ocorrências de vandalismo, segundo ponto de referência de localização, no período de setembro/2002 a maio/2003. Vitória.

Os tipos de vandalismo ocorridos nos PEVs foram agrupados em:

Vandalismo grave: queima total ou parcial do recipiente;

Vandalismo médio: pixação, retirada ou quebra de placa de informação ou da boca de carga; e,

Vandalismo leve: retirada dos adesivos da programação.

Verificou-se que, no geral, as ocorrências de vandalismo, segundo o tipo, estavam distribuídas conforme o gráfico 5.

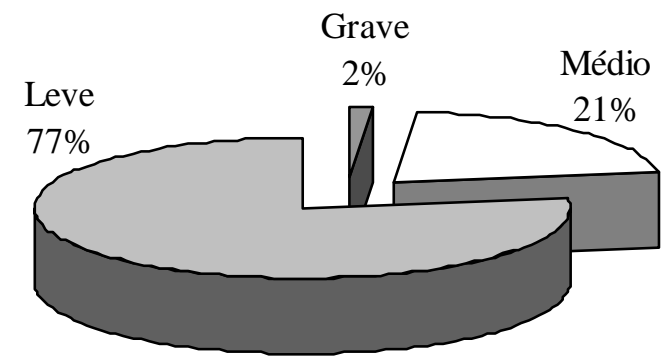

Gráfico 5 - Distribuição percentual dos tipos de vandalismo, no período de setembro/2002 a maio/2003. Vitória. 
Verificou-se que $15 \%$ dos PEVs instalados estavam localizados nas proximidades de escolas e que 50 \% das ocorrências de vandalismo grave ocorreram nestes PEVs. A freqüência de ocorrência de vandalismo em PEVs instalados nas proximidades de escolas causava surpresa a toda equipe envolvida no projeto.

Foi constatado, ainda, o baixo desempenho dos PEVs instalados nas proximidades de escolas, em termos da quantidade de materiais recicláveis armazenada.

Ainda quanto às escolas constatou-se que os diretores, professores e pessoal da escola, em geral, têm boa receptividade ao projeto, mas, na prática, quando cessava o estímulo externo da equipe de mobilização da coleta seletiva, retornavam para a sua rotina e não reservavam nenhum espaço para o reforço que a prática da coleta seletiva requer. Quanto aos alunos, a participação continuada se dava em função do estímulo da escola e/ou da equipe de mobilização da coleta seletiva da prefeitura.

No caso da ocorrência de situação de vandalismo grave, ou de freqüentes situações de vandalismo médio, o PEV era remanejado para outro local ou recolhido para o depósito da prefeitura, podendo retornar por solicitação da comunidade sendo acompanhado de nova ação de divulgação e mobilização da população do entorno.

As ocorrências de vandalismo de maior gravidade foram pontuais e as de menor gravidade foram, gradativamente, reduzindo-se. Em 2003, todos os PEVs anteriormente instalados em bairros de classe sócio-econômica D haviam sido retirados devido ao seu baixo desempenho, associado às situações de vandalismo. Os técnicos estudavam a possibilidade de buscar parcerias com empresas e entidades públicas e privadas instaladas em locais com grande fluxo de pessoas e facilidade de estacionamento para alavancar o projeto.

As dificuldades enfrentadas na operação do veículo de coleta dos PEVs, no período diurno, em regiões da cidade com tráfego mais intenso, levaram a equipe técnica a optar pela coleta noturna. A coleta automatizada e noturna propiciou a redução no tempo de coleta dos materiais recicláveis armazenados no PEV em até 3 vezes, em relação ao sistema anterior, coleta manual, conforme previsto no projeto de ampliação e modernização da coleta seletiva de Vitória.

Em 2003, aumentou significativamente o número de catadores autônomos nas ruas da cidade de Vitória, o que gerou disputa mais acirrada pelos recicláveis e despertou o interesse pelo material acumulado nos PEVs. Foram registradas ocorrências em 
que os catadores estavam tombando os PEVs e retirando pelos fundos toda a sua carga e, também, a existência de uma espécie de vara de pescar recicláveis, que era usada para retirada de materiais de maior valor, como latas de alumínio.

\section{.Coleta seletiva porta a porta}

O Sistema de Coleta Seletiva pela modalidade porta a porta teve suas operações iniciadas em 19 de novembro de 2002, atendendo a dois roteiros de coleta regular que correspondiam a 7 bairros e $10 \%$ da população do município.

O modelo de coleta seletiva porta a porta, implantado em Vitória, no qual dois dias de coleta regular foram substituídos pela coleta seletiva, gerava, de certa forma, um fator limitante para a população dos bairros envolvidos quanto à apresentação de seus resíduos sólidos à coleta, uma vez que os resíduos orgânicos ficariam armazenados por mais tempo nas residências, comércios, etc. As figuras 31 e 32 ilustram a operação da coleta seletiva porta a porta.

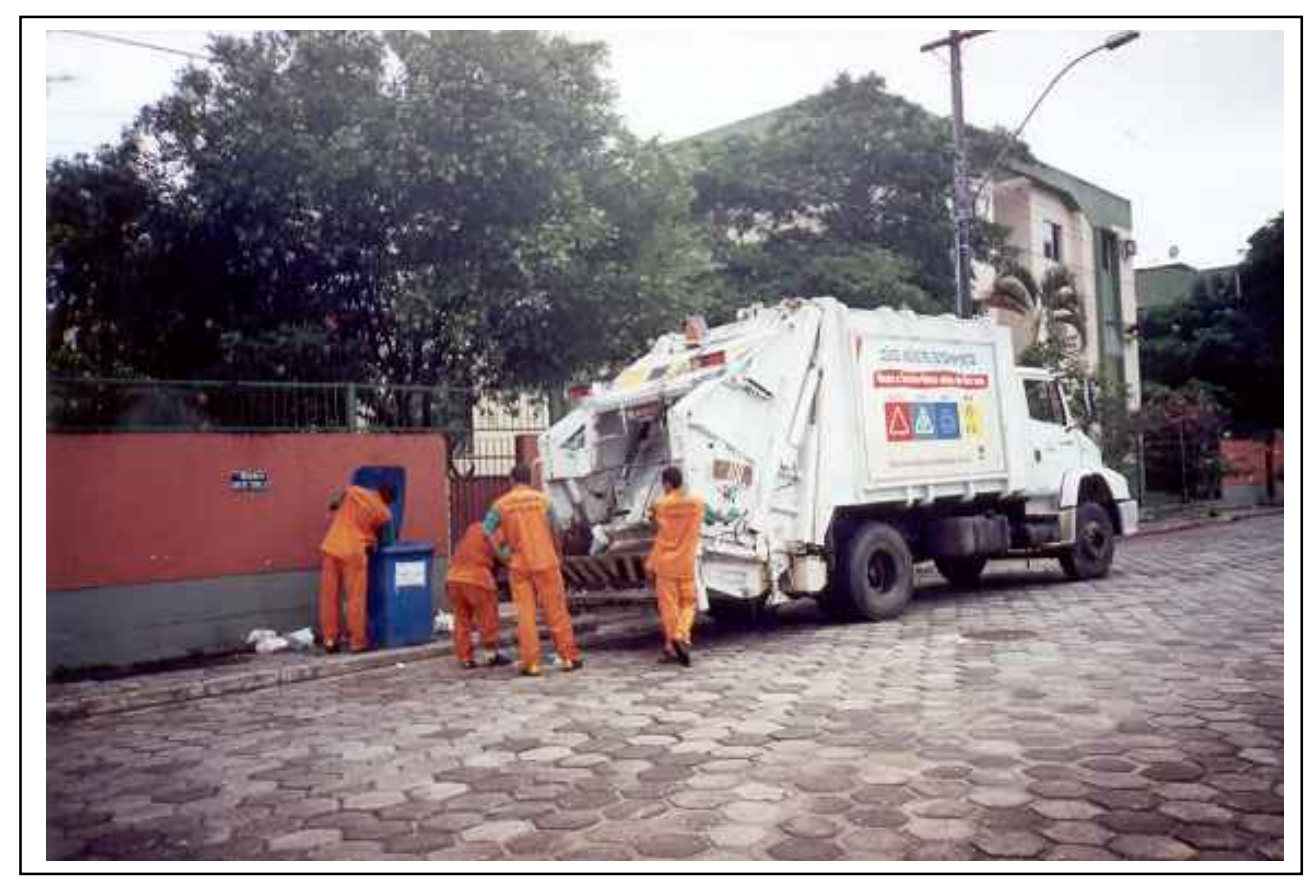

Figura 31 - Operação da coleta seletiva porta a porta, Vitória, 2003. 


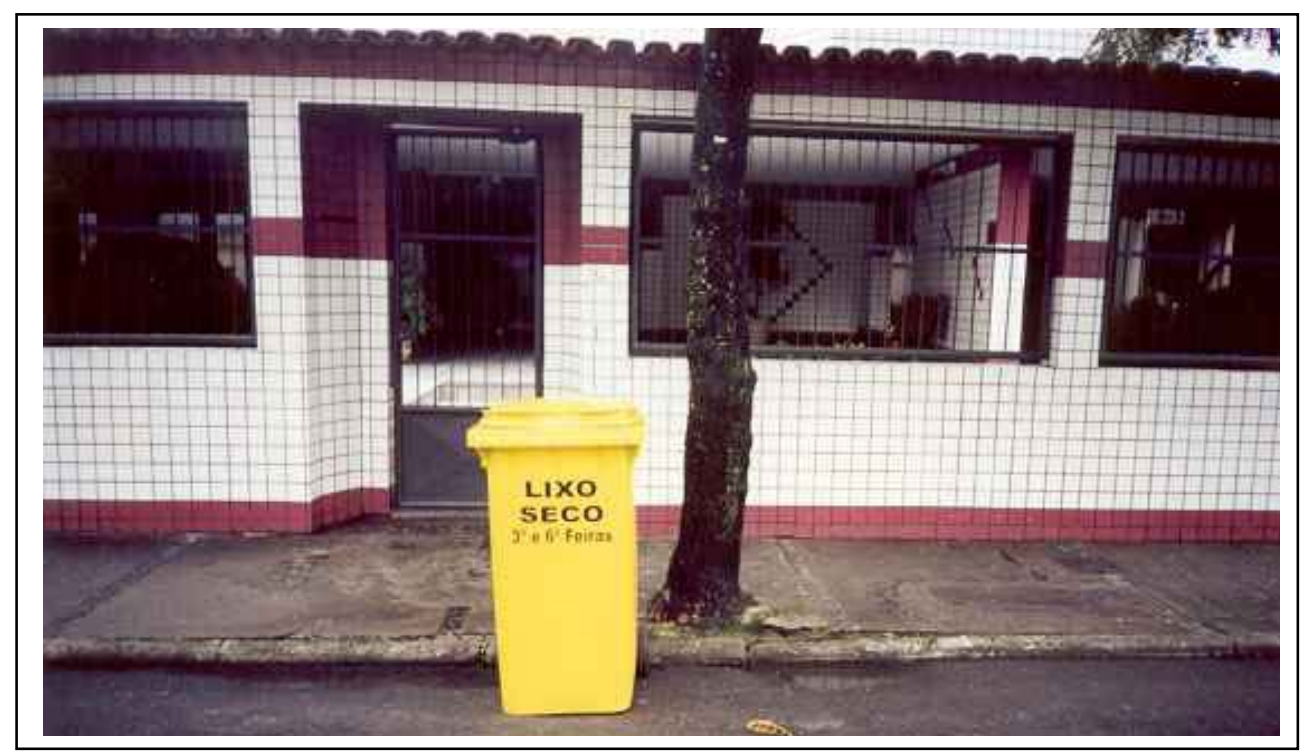

Figura 32 - Recipiente apropriado à coleta seletiva porta a porta, Vitória, 2003.

A coleta conteinirizada, com utiilização de contêineres com rodas, medida obrigatória em Vitória para os grandes geradores, trouxe impacto positivo na operação da coleta seletiva porta a porta, superando expectativas iniciais. Os resíduos úmidos, apresentados incorretamente e, portanto não coletados, ficavam armazenados nesses recipientes ao invés de estarem dispostos nas calçadas, sujeitos à ação de animais e vandalismo. Após o período da coleta seletiva porta a porta, esses contêineres, contendo resíduos não separados adequadamente, eram recolhidos pelo pessoal dos condomínios, sendo adequadamente armazenados até o próximo dia de coleta regular.

Nos dois primeiros meses após a implantação da coleta seletiva porta a porta, quando ainda estava presente a equipe da mobilização, foi observado que a população fiscalizava a ação da prefeitura, acompanhando a operação de coleta e vistoriando a separação dos resíduos dos vizinhos. A população ainda tinha dúvidas sobre a separação dos resíduos sólidos secos e resíduos sólidos úmidos, sendo necessário reforço constante na informação repassada. 
Foram observadas algumas escolas municipais com pouca participação, sendo informado posteriormente pelo setor competente da prefeitura que as mesmas adotavam ações próprias para tratar os seus resíduos sólidos.

Uma linha telefônica específica foi disponibilizada e divulgada à população como canal de comunicação e informação entre a prefeitura e a população. Essa linha telefônica conhecida como LIG-LIXO funcionava durante as 24 horas do dia.

A quantidade de ligações sobre a coleta seletiva porta a porta teve um pico inicial e foi gradativamente decrescendo ao longo dos meses (gráfico 6). Atribui-se tal situação aos seguintes aspectos: ausência de ações continuadas de divulgação, adaptação da rotina da população ao novo serviço e à possibilidade de subnotificação das ligações e demandas.

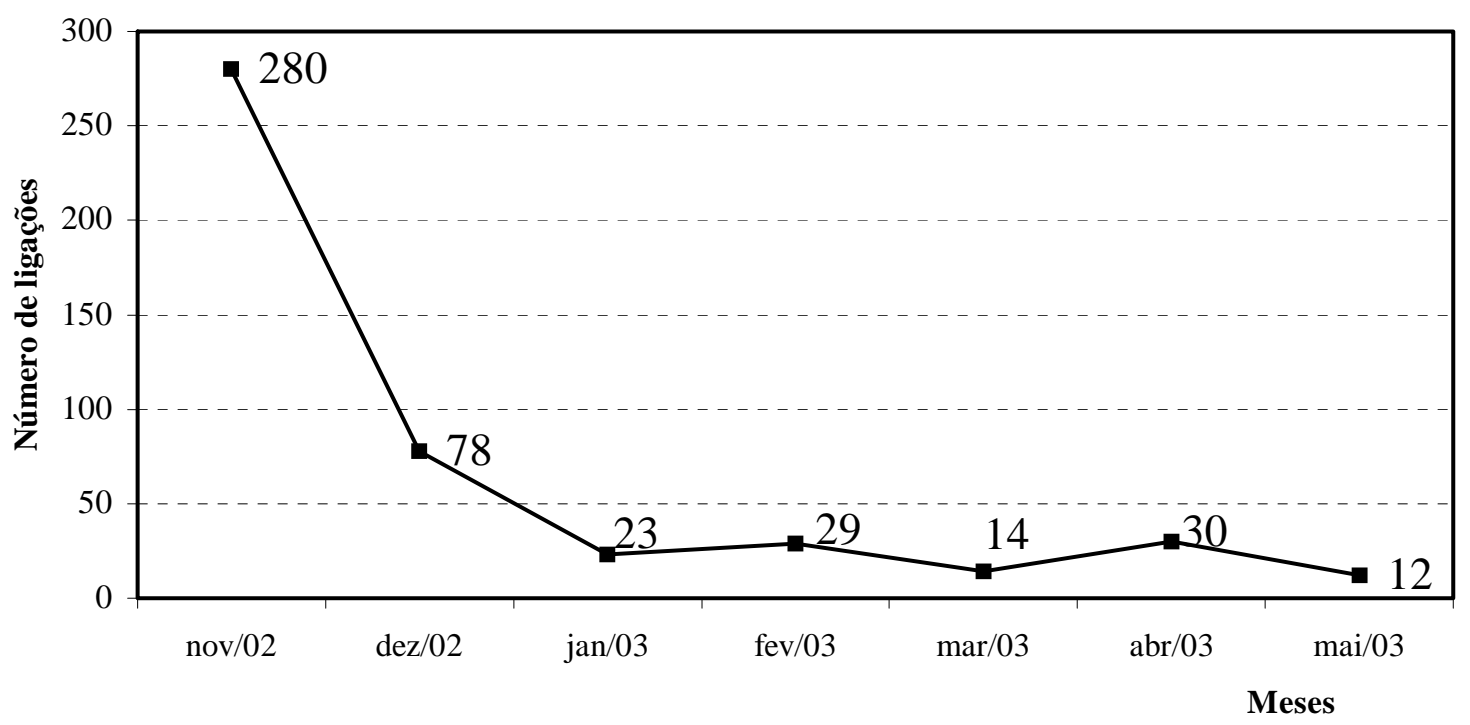

Gráfico 6 - Evolução de demandas do serviço LIG-LIXO para coleta seletiva porta a porta, no período de novembro de 2002 a maio de 2003.

Verificou-se que a quantidade de resíduos secos coletados mensalmente sofria diversas interferências, sendo a principal, a coleta paralela feita por catadores autônomos. Existiam, inclusive, sucateiros que passavam com veículos motorizados, antes da coleta da prefeitura para coletar os resíduos sólidos secos (figura 33). 


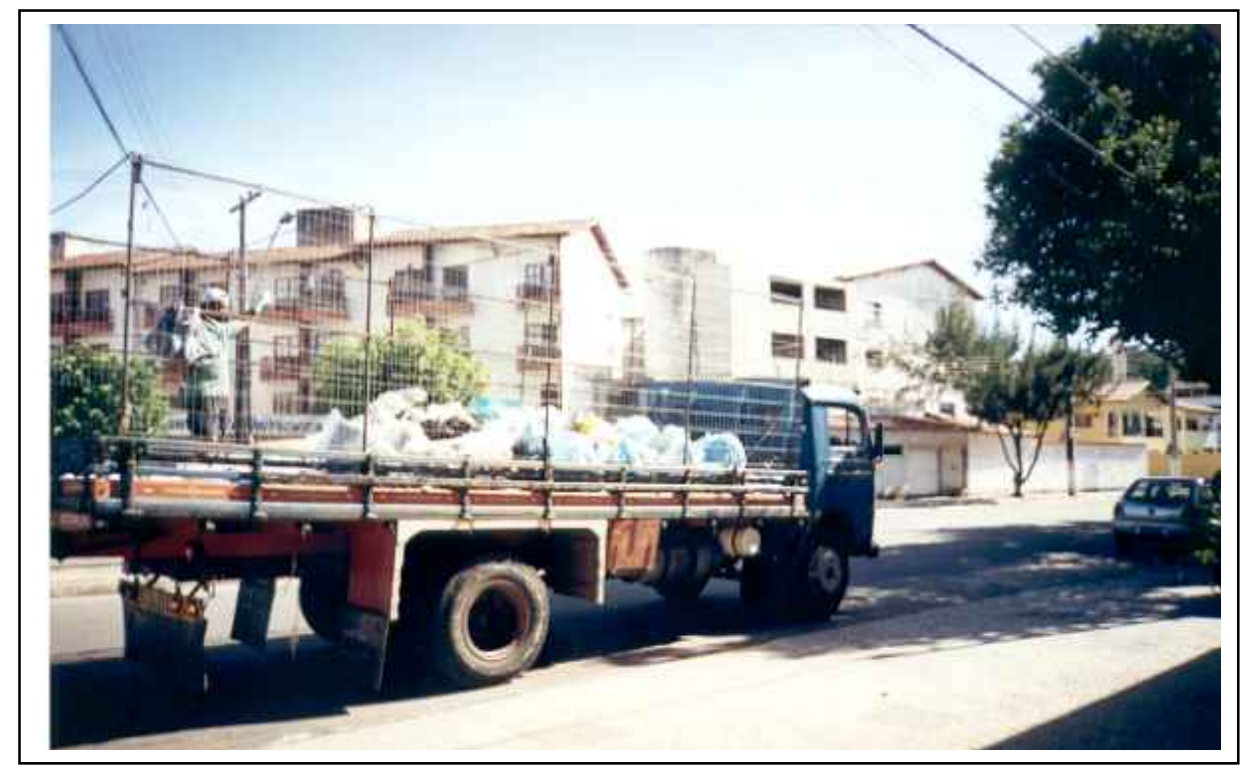

Figura 33 - Vista de caminhão gaiola de sucateiro, em região de coleta seletiva porta a porta, Vitória, 2003.

Não havia registro da quantidade de resíduos secos movimentada por esses catadores, visto que a quantidade de pessoas envolvidas em tal atividade varia em função de diversos fatores, dentre os quais destacavam-se as leis de mercado e a recessão econômica pela qual passa o país. Essa movimentação, no entanto, era estimada em cerca de $50 \%$, sendo que os catadores trabalham com os materiais de maior valor de mercado (papel, papelão, latas de alumínio, PET etc.).

O Gráfico 7, que apresenta a evolução da quantidade de resíduos sólidos secos coletados pela coleta seletiva porta a porta, segundo o roteiro de coleta, permite visualizar esta situação, ao longo do período estudado. 


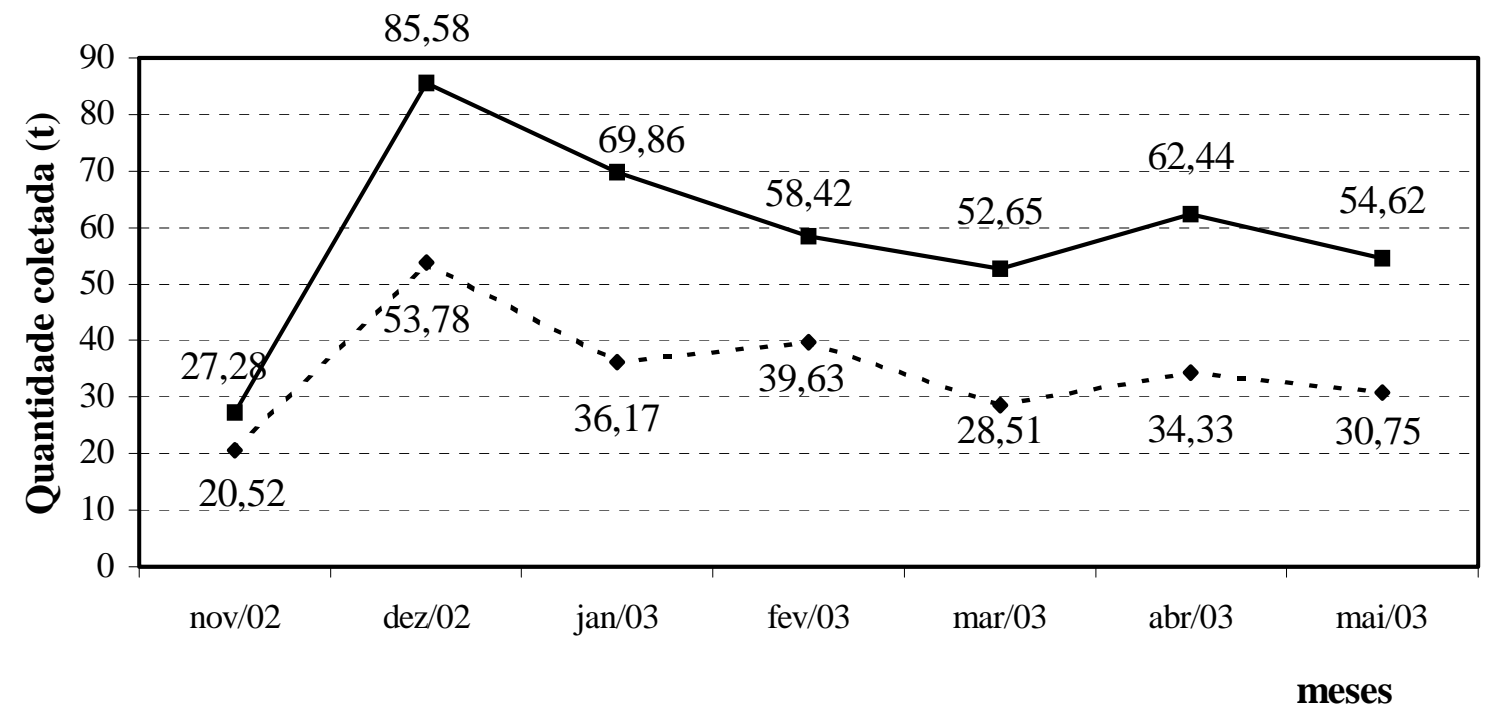

Gráfico 7 - Evolução da quantidade de resíduo seco coletado, na coleta seletiva porta a porta, no período de novembro/ 2002 a maio/ 2003. Vitória, 2003.

O roteiro de coleta seletiva porta a porta $3.1 \mathrm{~N}$ era noturno e envolvia 6 bairros de uma região da cidade pouco verticalizada. O roteiro $6.2 \mathrm{D}$ era diurno e envolvia 1 bairro, bastante verticalizado e com alta densidade populacional.

Para controlar a qualidade dos resíduos secos coletados eram realizadas análises de caracterização desses resíduos, mensalmente, nas dependências da UTCV. O parâmetro utilizado para comparação era o percentual de rejeito (gráfico 8), que compreendia a soma dos percentuais de matéria orgânica e outros materiais inadequados, contidos na amostra analisada. 


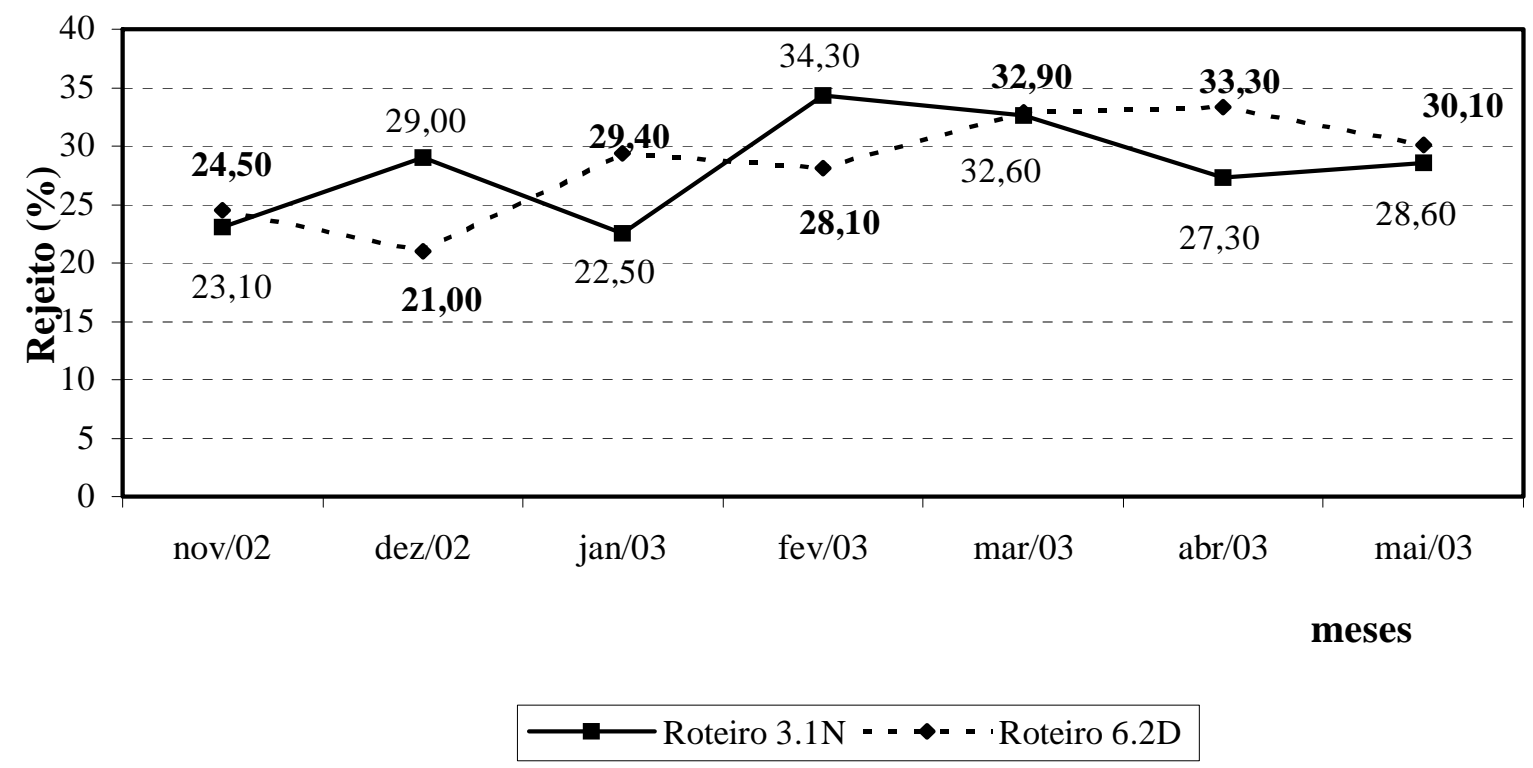

Gráfico 8 - Evolução do percentual de rejeito no lixo seco coletado, pela coleta seletiva porta a porta, no período de novembro/ 2002 a maio/ 2003. Vitória, 2003

Considerando-se que na coleta regular eram coletados resíduos sólidos com teores entre 50 e $60 \%$ de matéria orgânica, os resultados, quanto ao percentual de rejeitos, da coleta seletiva porta a porta, numa análise inicial, foram avaliados como ruins. Havia a preocupação, por parte da equipe técnica responsável pelo projeto, de que a coleta seletiva porta a porta poderia se tornar, com o tempo, uma coleta regular um pouco melhorada.

Entretanto, foi verificado que fatores externos interferiam na qualidade dos resíduos secos coletados, tais como: coleta paralela (catadores); falha nos procedimentos operacionais, no momento da coleta, pelas empresas contratadas; além da amostragem e técnica utilizada para o desenvolvimento da análise de caracterização física dos resíduos sólidos. Todos esses fatores não permitiram uma análise mais apurada do desempenho operacional da coleta seletiva porta a porta.

Tais resultados levaram os técnicos da prefeitura a propor a criação de uma equipe específica para trabalhar, rotineiramente, na realização de análises, estudando e 
propondo metodologias mais adequadas, bem como para obter informações sobre a coleta paralela.

Em fevereiro de 2003, foi realizado o cadastro dos catadores de lixo e sucateiros que desenvolviam a chamada “coleta seletiva paralela” nas regiões da coleta seletiva porta a porta com objetivo de buscar soluções para o problema.

\section{.Organizações de Trabalhadores Autônomos da Reciclagem}

Após 4 anos de implementação do projeto, a equipe envolvida observou avanços e retrocessos na organização dos catadores em vários aspectos, principalmente na questão social.

Apesar dos altos e baixos, a equipe considerava viável a coleta seletiva de Trabalhadores Autônomos da Reciclagem, enquanto geração de emprego e renda, no desenvolvimento da coleta seletiva e em especial no atendimento de seus aspectos sociais.

De modo geral, observava-se a necessidade de ajustes para consolidar o projeto, dentre estes destacavam-se: a oficialização da entidade; a capacitação do pessoal, principalmente, quanto à gestão da organização; e o aumento do número de associados, uma vez que o galpão tinha capacidade para absorver 15 catadores e, conseqüentemente, elevar a quantidade de materiais recicláveis triada por eles.

Em 2003, a meta era desenvolver uma proposta para inserir os catadores autônomos de forma ordenada no processo, por se entender que os mesmos representam uma realidade que não pode ser ignorada, sendo que muitas destas pessoas sobrevivem exclusivamente da catação de materiais recicláveis.

- Avaliação do programa de coleta seletiva implantado em Vitória

O registro sistemático de informações sobre os resíduos manejados pelo sistema de limpeza pública, incluindo os da coleta seletiva, foi uma característica positiva encontrada no município de Vitória. A prática de trabalhar esses dados e divulgar em forma de indicadores encontrava-se, gradativamente, em construção.

A coleta seletiva porta a porta estava sendo implantada, em parte da cidade, para fornecer subsídios para futura expansão do serviço a toda cidade e, por este motivo, possuía registro de dados mais detalhados. Da mesma forma que nas demais 
experiências visitadas, em Vitória os principais desafios eram a interface com os catadores e a mobilização social.

A equipe acreditava que a participação da população aumentaria gradativamente na medida em que aumentasse o trabalho de mobilização da comunidade. Entretanto, contrariando em parte as expectativas iniciais, a mesma estava dividida quanto a inteferência negativa que a coleta seletiva porta a porta desempenhava sobre a coleta por meio dos PEVs, nas regiões da cidade atendidas pelas duas modalidades. Parte do grupo acreditava que a utilização conjunta, das duas modalidades de coleta seletiva, não contribuía para aumentar as quantidades de materiais recicláveis coletados, somente acarretando maiores custos, e parte entendia que ainda era muito cedo para se chegar a tais conclusões.

Em maio de 2003, com a relização do balanço dos seis primeiros meses de operação da coleta seletiva, foi possível verificar os pontos críticos do programa implantado, que são:

- equipe técnica reduzida e infra-estrutura insuficiente para operar e monitorar a coleta seletiva;

- Plano Diretor de Limpeza Pública Municipal (coleta e varrição) desatualizado, não contemplando a coleta seletiva;

- limitações contratuais e orçamentárias para ampliação e manutenção da coleta seletiva;

- necessidade de revisão do Código Municipal de Limpeza Pública, incluindo a coleta seletiva;

- indefinição da política municipal com relação à questão dos catadores;

- cortes nos investimentos para divulgação, informação e mobilização em torno da coleta seletiva; e

- interferência da coleta paralela de materiais recicláveis feita por catadores autônomos.

\section{- Comparação das experiências de coleta seletiva visitadas}

As experiências de coleta seletiva visitadas nos municípios de São Bernardo do Campo-SP, Porto Alegre-RS, Florianópolis-SC e Santo André-SP possuíam, em comum, o foco da coleta seletiva como resgate da cidadania, em que a rotina de 
registro, tratamento e análise de informações operacionais, de cunho técnico e econômico, fica em segundo plano.

Verificou-se que a experiência do município de Vitória aproximava-se mais do foco coleta seletiva como instrumento de gerenciamento integrado de resíduos, estando em desenvolvimento ações de integração da coleta seletiva ao sistema de limpeza urbana local e a busca de formas adequadas para alcançar maior envolvimento da sociedade.

Um aspecto que chamou atenção nas experiências avaliadas foi a interferência significativa da implantação da coleta seletiva porta a porta no sistema existente de coleta regular, o que levou à alteração de velocidades de operação dos veículos de coleta e da densidade dos resíduos sólidos coletados, comprometendo a regularidade no cumprimento do horário de coleta e gerando reclamações da população.

No dia de coleta do resíduo seco, nos moldes operados pelos municípios visitados, a velocidade desenvolvida pelo veículo de coleta é maior, em relação a um dia normal da coleta regular; entretanto, no dia subseqüente, quando da coleta do lixo úmido, a velocidade da coleta cai, pois, além da maior quantidade de resíduo apresentada à coleta, o resíduo úmido é mais denso, exigindo maior esforço da guarnição e do veículo de coleta. O pessoal operacional equiparava o dia de coleta de resíduo úmido com a segunda-feira, dia da semana em que, normalmente, se coleta maior quantidade de resíduos sólidos domiciliares.

Normalmente, no Brasil, quando o serviço de coleta de resíduos sólidos urbanos é terceirizado, as empresas contratadas recebem dos municípios por tonelada coletada. Nesse caso, o conflito com a coleta seletiva porta a porta é ainda maior, pois a visão operacional existente é a de coletar a maior quantidade, com o mínimo de mão-deobra, no menor tempo e percurso possíveis. Essa filosofia não é adequada à operacionalização da coleta seletiva porta a porta.

A existência da coleta seletiva porta a porta gera, ainda, reflexos nas atividades de varrição e conservação de vias, principalmente, pelo maior acúmulo de resíduos em vias públicas após a coleta, por terem sido apresentados de forma inadequada pela população e recusado para a coleta regular, ou pela ação dos catadores. 
E, como nas experiências de coleta seletiva visitadas a operação estava subordinada à gerência responsável pela coleta regular municipal, em caso da necessidade de algum ajuste operacional que resultasse em reduções ou cortes, geralmente, o mesmo acontecia com a coleta seletiva.

A equipe de Santo André relatou que havia refeito o plano de varrição do município de modo que o serviço fosse executado, nas vias, após a coleta seletiva porta a porta. Quanto à coleta seletiva porta a porta, tem-se no quadro 9 a análise das características dos programas implantados nos municípios de Vitória, Porto Alegre, Florianópolis e Santo André. O município de São Bernardo do Campo não possuía, no momento da visita, essa modalidade de coleta seletiva. 
Quadro 9 - Características de Programas de Coleta Seletiva Porta a Porta

\begin{tabular}{|c|c|c|c|}
\hline \multirow{2}{*}{$\begin{array}{c}\text { Etapa Inicial - } 2002 \\
\text { Vitória/ ES }\end{array}$} & \multicolumn{3}{|c|}{ Experiência acumulada/ existente - 2002} \\
\hline & Porto Alegre/ RS & Florianópolis/ SC & Santo André/ SP \\
\hline $\begin{array}{l}\text { Equipamento: veículos do tipo coletor } \\
\text { compactador, da frota de coleta regular. } \\
\text { Triagem: Unidade de Triagem e }\end{array}$ & $\begin{array}{l}\text { Equipamento: veículos com carroceria } \\
\text { de madeira, aberta, de diversas } \\
\text { capacidades. }\end{array}$ & $\begin{array}{l}\text { Equipamento: veículos com carroceria } \\
\text { tipo baú, de diversos portes, e } 1 \text { veiculo } \\
\text { compactador. }\end{array}$ & $\begin{array}{l}\text { Equipamento: veículos do tipo coletor } \\
\text { compactador da frota de coleta regular. }\end{array}$ \\
\hline $\begin{array}{l}\text { Triagem: } \\
\text { Compostagem de Vitória (etapa inicial). }\end{array}$ & $\begin{array}{l}\text { Triagem: Associação de Catadores, } \\
\text { instaladas estrategicamente junto a Vilas } \\
\text { Habitacionais, com apoio técnico e } \\
\text { financeiro do município. }\end{array}$ & $\begin{array}{l}\text { Triagem: Associação de Catadores, } \\
\text { instalada junto ao Centro de } \\
\text { Transferência de Resíduos Sólidos de } \\
\text { Florianópolis, com apoio técnico e } \\
\text { financeiro do município e Associação de } \\
\text { Papeleiros no Centro da cidade. }\end{array}$ & $\begin{array}{l}\text { Triagem: Associações de Catadores, } \\
\text { instaladas junto ao Aterro Sanitário } \\
\text { Municipal com apoio técnico e financeiro } \\
\text { do município. }\end{array}$ \\
\hline & Rejeito da Triagem: $30 \%$ & Rejeito da Triagem: 10 a $15 \%$ & Rejeito da Triagem: 32 \% \\
\hline $\begin{array}{l}\text { Horário de coleta: diurno/noturno } \\
\text {.Regular - diária em toda a cidade, exceto } \\
\text { aos domingos. } \\
\text {.Seletiva - } 2 \text { dias de coleta de resíduo } \\
\text { sólido seco e } 4 \text { dias de úmido, seguindo } \\
\text { os horários anteriormente utilizados pela } \\
\text { coleta regular. }\end{array}$ & $\begin{array}{l}\text { Horário de coleta: diurno/noturno } \\
\text {.Regular - diária em zonas comerciais, } \\
\text { exceto aos domingos. Alternada no } \\
\text { restante da cidade. } \\
\text {.Seletiva - } 1 \text { vez por semana (diurna). } \\
\text { Cobertura: iniciou em } 1 \text { bairro classe } \\
\text { média, e foi crescendo, gradativamente, }\end{array}$ & $\begin{array}{l}\text { Horário de coleta: diurna/ noturna } \\
\text {.Regular - diária em zonas comerciais, } \\
\text { exceto aos domingos. Alternada no } \\
\text { restante da cidade. } \\
\text {.Seletiva - preferencialmente, diurna e } 01 \\
\text { vez por semana. Noturna no Centro. }\end{array}$ & $\begin{array}{l}\text { Horário de coleta: diurno/noturno, } \\
\text { seguindo o mesmo horário operado na } \\
\text { coleta regular, sendo } 2 \text { dias de coleta de } \\
\text { seco e } 3 \text { dias de úmido. }\end{array}$ \\
\hline $\begin{array}{l}\text { Cobertura: cerca de } 10 \% \text { do município } \\
\text { na fase inicial, envolvendo } 8 \text { bairros e } \\
38.655 \text { hab }\end{array}$ & $\begin{array}{l}\text { até atingir } 100 \text { \% do município. } \\
\text { Início: } 1990\end{array}$ & $\begin{array}{l}\text { Cobertura: iniciou em } 01 \text { bairro classe } \\
\text { média, e foi crescendo, gradativamente, } \\
\text { até atingir } 100 \% \text { da cidade. }\end{array}$ & $\begin{array}{l}\text { Cobertura: cresceu, gradativamente, de } \\
10 \% \text { (1997), para } 60 \% \text { (1999) até atingir } \\
100 \% \text { da cidade em } 2001 ;\end{array}$ \\
\hline Início: novembro/2002 & $\begin{array}{l}\text { Quantidade: estimativa de } 1657 \text { t/mês } \\
\text { (não pesada). }\end{array}$ & Início: 1994 & Início: 1997 \\
\hline Quantidade: 92 t/mês & Custo: R\$ 120,00/t (incluído a coleta & Quantidade: 180 t/mês & Quantidade: 1200 t/ mês \\
\hline Custo: $\mathrm{R} \$ 45,00 / \mathrm{t}$ (coleta) & $\begin{array}{l}\text { seletiva e a retirada do rejeito dos galpões } \\
\text { de triagem) }\end{array}$ & Custo: dado não fornecido & Custo: $\mathrm{R} \$ 43,30 / \mathrm{t}$ (coleta) \\
\hline Participação Avaliada*: & Participação Estimada*: 20 \% & $\begin{array}{l}\text { Participação Estimada*: dado não } \\
\text { fornecido }\end{array}$ & Participação Avaliada*: 35 \% \\
\hline
\end{tabular}

* Participação populacional avaliada ou estimada, em função da população total da área do município contemplada com a coleta seletiva porta a porta 
No geral as experiências avaliadas apresentaram diversos aspectos comuns relativos às dificuldades na implantação e operação dos projetos, os quais estão sistematizados a seguir:

- os custos de implantação e operação da coleta seletiva, nos moldes adotados pelos municípios, são altos;

- a escala da coleta seletiva não aumenta na mesma proporção que os investimentos;

- falta equipe qualificada para trabalhar, exclusivamente, com a coleta seletiva;

- faltam recursos para realizar e manter ações de divulgação e motivação da população;

- falta monitoramento da participação da população que, geralmente, é baixa;

- falta metodologia de acompanhamento e registro sistemático de informações;

- há um decaimento gradual das quantidades coletadas pela coleta seletiva;

- verifica-se a ausência e/ou variações do mercado de recicláveis;

- a ação dos catadores autônomos que levam o material reciclável antes da coleta seletiva municipal prejudica o processo;

- cresce rapidamente o número de catadores autônomos e há dificuldade de integração dos mesmos aos programas estabelecidos pelos municípios; e,

- constata-se ausência de políticas públicas para coleta seletiva, catadores e mercado de recicláveis.

A experiência de Vitória demonstrou que, nos moldes adotados pelo município, em uma mesma área, os custos da coleta seletiva porta a porta eram mais reduzidos e que a mesma conseguia coletar uma quantidade maior de recicláveis em relação à coleta por meio de PEVs. Observa-se, entretanto, que a qualidade do material reciclável, proveniente da coleta seletiva porta a porta, era inferior à dos recicláveis coletados por PEVs, até mesmo pela maior interferência da ação dos catadores, sobre a qual não se tem controle.

Quanto ao decaimento gradual das quantidades coletadas pela coleta seletiva, cabe analisar também que ao longo dos anos os resíduos sólidos urbanos sofrem alteração em sua composição e conseqüentemente em sua densidade. No Brasil verifica-se que os resíduos urbanos estão ficando mais leves devido, por exemplo, à substituição de embalagens como as de vidro e metal pelo plástico, com reflexos na coleta seletiva . 
Assim, torna-se necessário implementar um sistema de acompanhamento e controle da qualidade do material reciclável coletado, para não se incorrer no erro de realizar coleta seletiva que resulte em coleta de recicláveis com as mesmas características dos resídos provenientes da coleta regular e divulgar à população que o município faz coleta seletiva.

As informações obtidas, a partir das experiências de coleta seletiva nos municípios selecionados, reforçam a necessidade de se desenvolver estudos e pesquisas sobre o tema no país. 


\subsection{Pesquisa sobre Indicadores Operacionais}

A seguir são apresentados os resultados das etapas de pesquisa sobre Indicadores Operacionais, com as Fases 1 e 2, e sobre a participação social, com as Fases 3 a 5, desenvolvidas para investigar as Hipóteses 1 e 2, formuladas no capítulo 3 da presente tese.

\section{Fase 1 - Estabelecimento de Grupo de Indicadores}

Como resultado da Fase 1, identificou-se os principais indicadores utilizados para o planejamento e a avaliação de desempenho em Programas de Coleta Seletiva de resíduo sólido urbano no Brasil e instituiu-se um grupo de indicadores de referência, adotando-se critérios desejáveis de qualidade, visando à maior garantia de sua utilização futura. Esses indicadores são apresentados a seguir.

\subsubsection{Principais indicadores utilizados para o planejamento e a avaliação de coleta seletiva no Brasil}

A partir da revisão bibliográfica e dos dados obtidos junto às experiências de coleta seletiva visitadas, chegou-se a 25 indicadores, os quais vêm sendo utilizados para o planejamento e a avaliação da coleta seletiva no Brasil. Dentre estes, 19 indicadores são de caráter geral, ou seja, aplicáveis a quaisquer modalidades de coleta seletiva, 3 específicos para coleta seletiva por PEVs e 3 para coleta seletiva autônoma.

A seguir, são apresentados os indicadores identificados, mantendo-se a nomenclatura originalmente adotada pelos autores pesquisados, conforme apresentado no capítulo 2 que trata da revisão da literatura.

\section{Indicadores Gerais}

1. Cobertura de atendimento do programa (\%);

2. Índice de recuperação de materiais recicláveis (\%);

3. Custo unitário mensal da coleta e transporte $(\mathrm{R} \$ / \mathrm{t})$;

4. Custo unitário de triagem $(\mathrm{R} \$ / \mathrm{t})$;

5. Custo unitário total da coleta seletiva $(\mathrm{R} \$ / \mathrm{t})$;

6. Eficiência de mão-de-obra de triagem $(\mathrm{t} /$ trabalhador $/ \mathrm{h})$;

7. Investimento per capita anual no programa (R\$/hab/ano); 
8. Percentual mensal de reclamações/ não conformidades (\%);

9. Despesa com marketing e educação (R $\$ / h a b / a n o)$;

10. Freqüência média da coleta ( $\mathrm{n}^{\circ}$ de coletas/semana);

11. Percentual de resíduos orgânicos nos resíduos da coleta seletiva (\%);

12. Percentual de resíduos recicláveis presentes no lixo da coleta regular (\%);

13. Densidade de coleta $(\mathrm{t} / \mathrm{h})$;

14. Eficiência de coleta seletiva $(\mathrm{t} / \mathrm{h} / \mathrm{km})$;

15. Quantidade mensal coletada seletivamente ( $\mathrm{t} / \mathrm{mês})$;

16. Quantidade de itens de materiais recicláveis comercializados (un);

17. Preço médio de comercialização do mix de materiais recicláveis $(\mathrm{R} \$ / \mathrm{t})$;

18. Receita apurada em vendas (R\$); e,

19. Relação Receita/Despesa.

\section{Indicadores Específicos}

\section{A - Coleta Seletiva por PEVs :}

20. Quantidade de PEVs instalados (un);

21. Quantidade média de recicláveis por PEV ( $\mathrm{t} / \mathrm{PEV})$; e,

22. Percentual mensal de vandalismo em PEVs (\%).

\section{B- Coleta Seletiva Autônoma - Organização de Trabalhadores Autônomos :}

23. Quantidade de catadores envolvidos (un);

24. Renda média mensal (R \$/catador); e,

25. Percentual de rotatividade de catadores (\%).

No anexo 1 são apresentados os 25 indicadores com suas respectivas definições e formas de apuração.

\subsubsection{Grupo de Indicadores de referência para planejamento e avaliação da coleta seletiva}

Partindo-se dos 25 indicadores, identificados como os principais e empregados no planejamento e na avaliação de coleta seletiva no Brasil, foi realizada a validação de um grupo de indicadores de referência, utilizando-se de instrumentos de pesquisa quantitativa associados a métodos estatísticos. Sendo, esse grupo de indicadores de 
referência, num total de 6 indicadores, extraído dos 25 indicadores inicialmente identificados.

A partir da aplicação de questionários foram realizadas Análise Descritiva, Análise Multifatorial e Técnica Delphi dos dados e os resultados são apresentados nos itens 6.2.2.1 e 6.2.2.2.

\subsubsection{Coleta e Análise de Dados}

\section{Analise Descritiva}

Para a análise descritiva aplicou-se o questionário, que está apresentado no anexo 2, a especialistas da área de estudo. O questionário foi subdividido em duas partes: Parte I - Identificação do informante e Parte II - Avaliação de indicadores de coleta seletiva de resíduos sólidos urbanos.

Para as variáveis da Parte I, que tratam do perfil do entrevistado, foram montadas tabelas de freqüência absoluta e relativa e elaborados gráficos apropriados. Para traçar o perfil dos entrevistados, buscou-se dados quanto ao estado brasileiro onde residem (origem), formação acadêmica e existência de período de experiência com programas de coleta seletiva.

Para os 25 indicadores (Parte II) foram calculados parâmetros estatísticos básicos (Média, Desvio Padrão, valor mínimo e máximo), elaborados gráficos tipo box - plot e médias e realizado um agrupamento de indicadores segundo o grau de importância médio obtido.

O programa estatístico utilizado foi o Statistical Package for the Social Sciences, SPSS (2003), versão 8.0, que processou dados, permitindo a interpretação dos resultados.

\section{Parte I - Identificação do Informante}

Dos 57 questionários que retornaram preenchidos, 34 vieram do Espírito Santo, seguido de São Paulo com 10, Minas Gerais com 4, Brasília, Rio de Janeiro e Rio Grande do Sul com 2 cada e Bahia, Santa Catarina e Ceará com 1 questionário cada. Quanto ao nível de escolaridade dos 57 participantes desta pesquisa, 28,1\% eram graduados em nível superior, 22,8\% apresentavam ainda título de especialistas, 26,3\% 
mestrado e $15,8 \%$ doutorado. $77,2 \%$ possuem experiência relacionada a programas de coleta seletiva, sendo esta experiência superior a 2 anos, na maioria dos participantes (42,1\%), e de 1 a 2 anos para $15,8 \%$ deles.

\section{Parte II - Avaliação de Indicadores de coleta seletiva de resíduos sólidos urbanos}

No questionário utilizado para validação dos indicadores, os entrevistados atribuíram a cada um dos 25 indicadores apresentados, notas variando de 0 a 10 ou escolheram a opção "não sabe". Alguns entrevistados não atribuíram notas a todos os indicadores propostos e marcaram a opção "não sabe", deixando parte do questionário sem resposta.

Observa-se que para fins de aplicação dos métodos estatísticos adotados, era necessário que os indicadores fossem tratados como variáveis (var). Assim, foram estabelecidos números de referência para cada indicador, de 1 a 25, os quais foram apresentados em ordem aleatória no questionário. Esta numeração de variáveis (var) esta presente nas tabelas 1, 2, 5 a 9 e Quadro 10.

A tabela 1 apresenta a descrição dos resultados da avaliação dos indicadores feita pelos entrevistados, considerando-se os seguintes atributos:

- N Válido - representa o número de respostas válidas em relação aos 25 indicadores apresentados;

- Não Sabe/ Não Respondeu - representa o número de respostas "não sabe" ou indicadores sem avaliação (em branco);

- Média - representa a nota média atribuída a cada indicador, ou seja, o quociente da divisão da soma das notas atribuídas ao indicador pelo número de notas atribuídas;

- Desvio Padrão - representa uma quantidade que mede a amplitude de variação em torno da média, de um conjunto de medidas;

- V mínimo - representa a nota mínima atribuída ao indicador; e,

- V máximo - representa a nota máxima atribuída ao indicador. 
Tabela 1 - Resultados da avaliação dos indicadores, feita pelos entrevistados, segundo estatística descritiva.

\begin{tabular}{|c|c|c|c|c|c|c|c|}
\hline Var & INDICADOR & $\begin{array}{c}\mathbf{N} \\
\text { Válido }\end{array}$ & $\begin{array}{l}\text { não sabe/ } \\
\text { não } \\
\text { respondeu }\end{array}$ & Média & $\begin{array}{l}\text { Desvio } \\
\text { Padrão }\end{array}$ & $\begin{array}{l}\text { V. } \\
\text { Min. }\end{array}$ & $\begin{array}{l}\text { V. } \\
\text { Máx. }\end{array}$ \\
\hline 1 & Cobertura do atendimento (hab) & 54 & 3 & 8,54 & 2,13 & 3 & 10 \\
\hline 2 & $\begin{array}{l}\text { IRMR - Índice de Recuperação de Materiais } \\
\text { Recicláveis (\%) }\end{array}$ & 53 & 4 & 8,51 & 1,93 & 2 & 10 \\
\hline 3 & Despesa com marketing e educação ( $\mathrm{R} \$ / \mathrm{hab} / \mathrm{ano})$ & 54 & 3 & 7,44 & 2,16 & 2 & 10 \\
\hline 4 & $\begin{array}{l}\text { Investimento per capita anual no programa } \\
\text { (R\$/ hab/ano) }\end{array}$ & 55 & 2 & 7,45 & 1,73 & 3 & 10 \\
\hline 5 & Relação Receita/Despesa & 54 & 3 & 7,07 & 2,10 & 1 & 10 \\
\hline 6 & Quantidade de PEVs instalados (un) & 55 & 2 & 6,53 & 2,27 & 1 & 10 \\
\hline 7 & $\begin{array}{l}\text { Quantidade mensal de catadores autônomos envolvidos } \\
\text { na organização (catadores/mês) }\end{array}$ & 55 & 2 & 6,96 & 1,90 & 3 & 10 \\
\hline 8 & $\begin{array}{l}\text { Preço médio de comercialização do mix de material } \\
\text { reciclável }(\mathrm{R} \$ / \mathrm{t})\end{array}$ & 52 & 5 & 6,79 & 1,95 & 1 & 10 \\
\hline 9 & Freqüência média de coletas ( $\mathrm{n}^{\circ}$ de coletas/semana) & 57 & 0 & 7,58 & 2,07 & 1 & 10 \\
\hline 10 & Produção média de recicláveis por PEV (t/PEV) & 54 & 3 & 7,22 & 2,12 & 1 & 10 \\
\hline 11 & $\begin{array}{l}\text { Percentual de resíduos recicláveis no lixo da coleta } \\
\text { regular }(\%)\end{array}$ & 56 & 1 & 7,86 & 2,10 & 2 & 10 \\
\hline 12 & Densidade de coleta $(\mathrm{t} / \mathrm{h})$ & 53 & 4 & 6,42 & 2,48 & 2 & 10 \\
\hline 13 & Percentual de rotatividade de catadores autônomos (\%) & 49 & 8 & 5,82 & 2,20 & 2 & 10 \\
\hline 14 & Custo mensal de operação da coleta e transporte $(\mathrm{R} \$ / \mathrm{t})$ & 55 & 2 & 7,80 & 1,95 & 2 & 10 \\
\hline 15 & $\begin{array}{l}\text { Percentual mensal de reclamações/não conformidades } \\
(\%)\end{array}$ & 54 & 3 & 7,15 & 2,32 & 1 & 10 \\
\hline 16 & $\begin{array}{l}\text { Percentual de resíduos orgânicos no lixo da coleta } \\
\text { seletiva }(\%)\end{array}$ & 51 & 6 & 7,71 & 2,37 & 2 & 10 \\
\hline 17 & Índice mensal de vandalismo PEVs (\%) & 57 & 0 & 6,91 & 2,70 & 1 & 10 \\
\hline 18 & Quantidade mensal coletada seletivamente ( $\mathrm{t} / \mathrm{mês}$ ) & 52 & 5 & 8,13 & 2,08 & 3 & 10 \\
\hline 19 & Custo de triagem $(\mathrm{R} \$ / \mathrm{t})$ & 50 & 7 & 8,00 & 1,84 & 1 & 10 \\
\hline 20 & $\begin{array}{l}\text { Quantidade de itens de materiais recicláveis } \\
\text { comercializados (un) }\end{array}$ & 55 & 2 & 7,78 & 2,07 & 3 & 10 \\
\hline 21 & $\begin{array}{l}\text { Renda média mensal por catador autônomo } \\
\text { (R\$/catador/mês) }\end{array}$ & 52 & 5 & 8,13 & 1,67 & 4 & 10 \\
\hline 22 & $\begin{array}{l}\text { Eficiência de mão-de-obra de triagem } \\
\text { (t/trabalhador/hora) }\end{array}$ & 52 & 5 & 7,67 & 1,93 & 1 & 10 \\
\hline 23 & Custo total da coleta seletiva $(\mathrm{R} \$ / \mathrm{t})$ & 53 & 4 & 8,32 & 2,05 & 2 & 10 \\
\hline 24 & Receita apurada em vendas ( $\mathrm{R} \$$ / mês) & 54 & 3 & 7,31 & 2,66 & 1 & 10 \\
\hline 25 & Eficiência da coleta seletiva $(\mathrm{t} / \mathrm{km} / \mathrm{h})$ & 55 & 2 & 8,16 & 2,16 & 1 & 10 \\
\hline
\end{tabular}

Cabe ressaltar que, no questionário utilizado, as notas, variando de 1 a 10, estavam agrupadas segundo o grau de importância, da seguinte forma:

- nota variando de 1 a 3 - pouca importância;

- nota variando de 4 a 7 - média importância; e,

- nota variando de 8 a 10 - muita importância. 
Para representação dos resultados da variação das notas, atribuídas aos 25 indicadores apresentados no questionário, foram adotados gráficos do tipo Box Plot, considerados os mais adequados dentre os disponíveis no SPSS para tal finalidade. Tais gráficos são baseados na mediana, quartil e valores extremos. A linha no centro da caixa indica a mediana. As linhas que estendem a caixa representam os valores mais altos e mais baixos, enquanto os pontos acima ou abaixo destas linhas representam os valores discrepantes (outliers). Da linha mediana até as linhas que estendem a caixa alcançam-se $50 \%$ dos valores.

Os valores discrepantes encontrados estão representados pelos símbolos:

$\mathrm{O} \rightarrow$ os pontos discrepantes

* $\rightarrow$ os pontos altamente discrepantes

Para representar um desvio-padrão, a mais ou a menos em torno da média, foi utilizado o Gráfico de Médias, denominado pelo programa estatístico SPSS como Erro Bar.

A seguir, apresentam-se nos gráficos 9 e 10 todos os indicadores, segundo o Box-Plot e o Gráfico de Médias (Erro Bar).

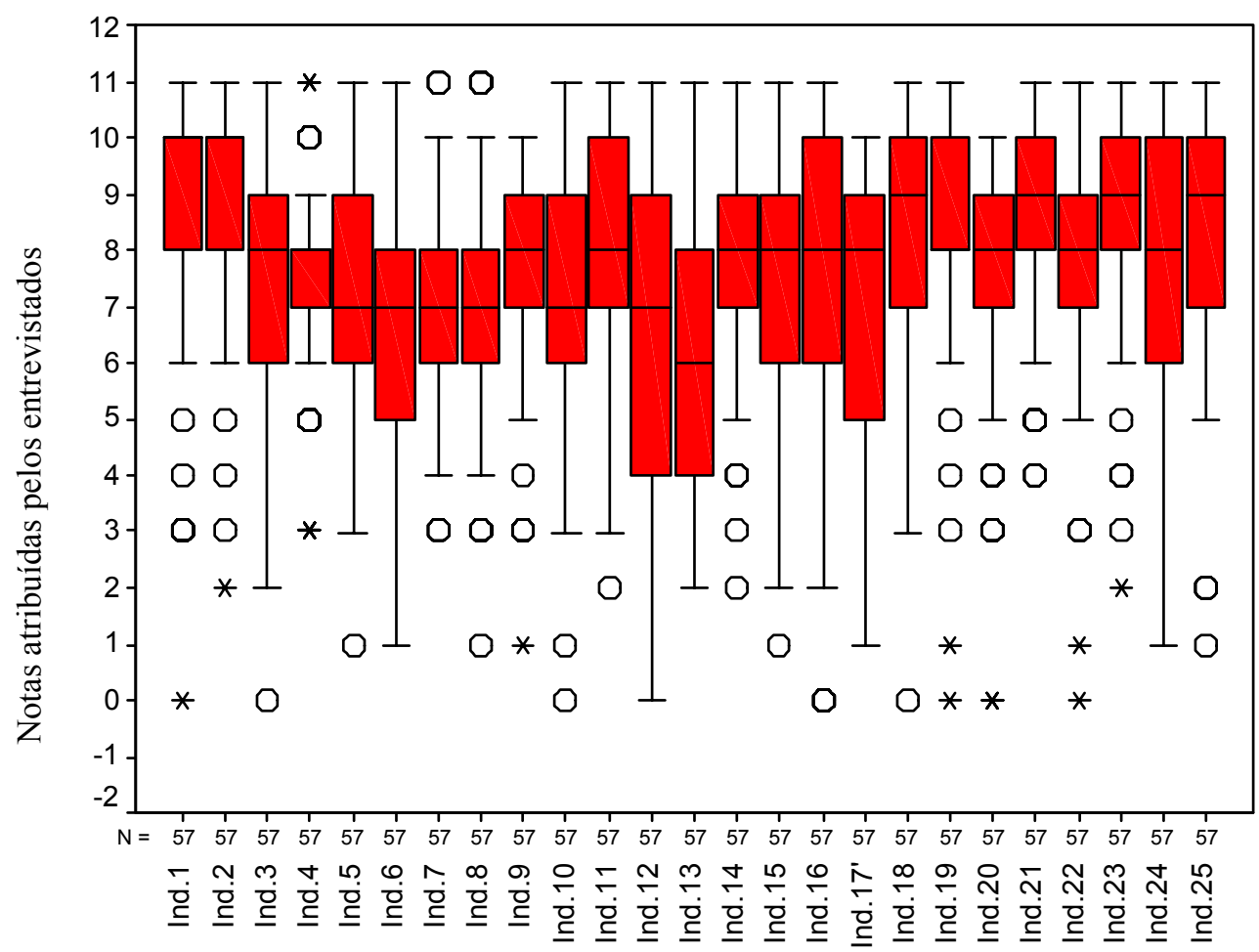

Gráfico 9 - Box Plot de todos os indicadores propostos. 


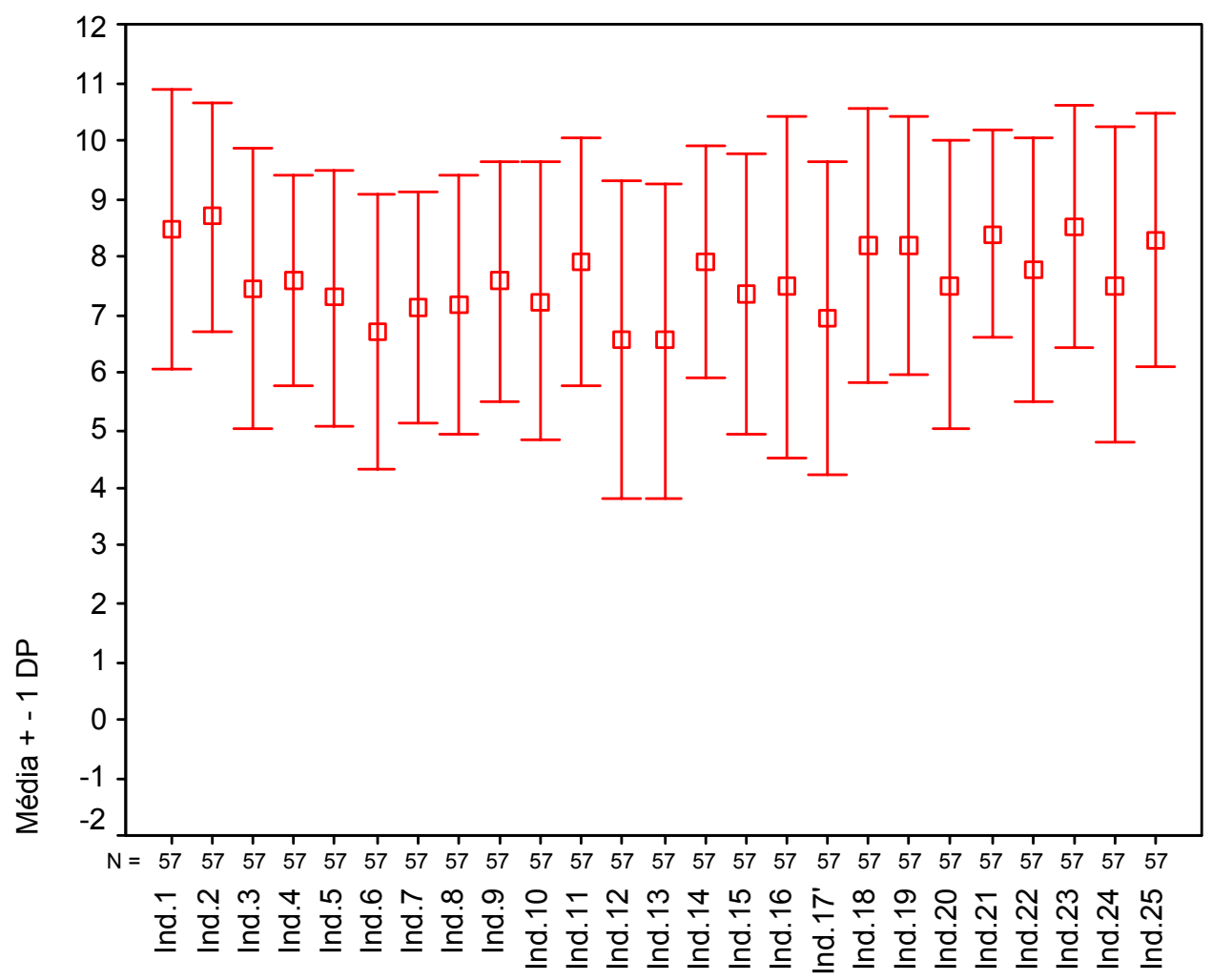

Gráfico 10 - Erro Bar de todos os indicadores propostos.

Verifica-se que 5 indicadores, dentre os 25 apresentados para avaliação, não apresentaram valores discrepantes em termos da variação das notas atribuídas pelos entrevistados. Sendo os mesmos: quantidade de PEVs instalados (un), Var 6; densidade de coleta $(\mathrm{t} / \mathrm{h})$, Var 12; percentual de rotatividade de catadores autônomos (\%), Var 13; índice mensal de vandalismo PEVs (\%), Var 17 e receita apurada em vendas (R $\$$ / mês), Var 24, conforme apresentado no gráfico 9.

No gráfico 10 observa-se que a avaliação média dos indicadores varia entre os graus de média importância (4 a 7) e muita importância (8 a 10), tendo o indicador percentual de rotatividade de catadores autônomos (\%) (Var 13) apresentado menor avaliação média $(5,82)$ e o indicador cobertura de atendimento (hab) (Var 1) maior avaliação média $(8,54)$. O indicador renda média mensal por catador autônomo (R \$/catador/mês), Var 21, apresentou menor variação em torno da média $(1,67)$, em relação aos demais indicadores. O indicador índice mensal de vandalismo PEVs (\%), 
Var 17, apresentou média igual a 6,91 e maior variação em torno da média, 2,70. Os demais indicadores apresentaram desvio padrão variando entre 1,73 e 2,66.

A análise, apresentada do gráfico 10, fica mais evidente a partir dos resultados da tabela 2. A tabela 2 e os gráficos 11, 12, 13 e 14 apresentam o resultado da avaliação dos indicadores segundo opinião dos entrevistados, segundo grau crescente de importância atribuída. 
Tabela 2 - Descrição dos resultados da avaliação dos indicadores feita pelos entrevistados, segundo estatística descritiva por grau de importância.

\begin{tabular}{|c|c|c|c|c|c|c|c|}
\hline Var & INDICADOR & $\begin{array}{c}\mathbf{N} \\
\text { Válido }\end{array}$ & $\begin{array}{l}\text { Não Sabe/ } \\
\text { Não } \\
\text { Respondeu }\end{array}$ & Média & $\begin{array}{l}\text { Desvio } \\
\text { Padrão }\end{array}$ & $\begin{array}{l}\text { V. } \\
\text { Min. }\end{array}$ & $\begin{array}{l}\text { V. } \\
\text { Máx }\end{array}$ \\
\hline \multicolumn{8}{|c|}{ Média Importância * } \\
\hline 13 & $\begin{array}{l}\text { Percentual de rotatividade de catadores autônomos } \\
\qquad(\%)\end{array}$ & 49 & 8 & 5,82 & 2,2 & 2 & 10 \\
\hline 12 & Densidade de coleta $(\mathrm{t} / \mathrm{h})$ & 53 & 4 & 6,42 & 2,48 & 2 & 10 \\
\hline 6 & Quantidade de PEVs instalados (un) & 55 & 2 & 6,53 & 2,27 & 1 & 10 \\
\hline 8 & $\begin{array}{l}\text { Preço médio de comercialização do mix de material } \\
\text { reciclável }(\mathrm{R} \$ / \mathrm{t})\end{array}$ & 52 & 5 & 6,79 & 1,95 & 1 & 10 \\
\hline 17 & Índice mensal de vandalismo PEVs (\%) & 57 & 0 & 6,91 & 2,7 & 1 & 10 \\
\hline 7 & $\begin{array}{l}\text { Quantidade mensal de catadores autônomos } \\
\text { envolvidos na organização (catadores/mês) }\end{array}$ & 55 & 2 & 6,96 & 1,9 & 3 & 10 \\
\hline 5 & Relação Receita/Despesa & 54 & 3 & 7,07 & 2,1 & 1 & 10 \\
\hline 15 & 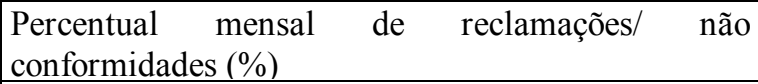 & 54 & 3 & 7,15 & 2,32 & 1 & 10 \\
\hline 10 & Produção média de recicláveis por PEV (t/PEV) & 54 & 3 & 7,22 & 2,12 & 1 & 10 \\
\hline 24 & Receita apurada em vendas ( $\mathrm{R} \$$ / mês) & 54 & 3 & 7,31 & 2,66 & 1 & 10 \\
\hline 3 & Despesa com marketing e educação (R $\$$ /hab/ano) & 54 & 3 & 7,44 & 2,16 & 2 & 10 \\
\hline 4 & $\begin{array}{l}\text { Investimento per capita anual no programa ( } \mathrm{R} \$ / \\
\text { hab/ano) }\end{array}$ & 55 & 2 & 7,45 & 1,73 & 3 & 10 \\
\hline 9 & Freqüência média de coletas ( ${ }^{\circ}$ de coletas/semana) & 57 & 0 & 7,58 & 2,07 & 1 & 10 \\
\hline 22 & $\begin{array}{l}\text { Eficiência de mão-de-obra de triagem } \\
\text { (t/trabalhador/hora) }\end{array}$ & 52 & 5 & 7,67 & 1,93 & 1 & 10 \\
\hline 16 & $\begin{array}{l}\text { Percentual de resíduos orgânicos no lixo da coleta } \\
\text { seletiva }(\%)\end{array}$ & 51 & 6 & 7,71 & 2,37 & 2 & 10 \\
\hline 20 & $\begin{array}{l}\text { Quantidade de itens de materiais recicláveis } \\
\text { comercializados (un) }\end{array}$ & 55 & 2 & 7,78 & 2,07 & 3 & 10 \\
\hline 14 & $\begin{array}{l}\text { Custo mensal de operação da coleta e transporte } \\
(\mathrm{R} \$ / \mathrm{t})\end{array}$ & 55 & 2 & 7,8 & 1,95 & 2 & 10 \\
\hline 11 & $\begin{array}{l}\text { Percentual de resíduos recicláveis no lixo da coleta } \\
\text { regular }(\%)\end{array}$ & 56 & 1 & 7,86 & 2,1 & 2 & 10 \\
\hline \multicolumn{8}{|c|}{ Muito Importante * } \\
\hline 19 & Custo de triagem $(\mathrm{R} \$ / \mathrm{t})$ & 50 & 7 & 8,00 & 1,84 & 1 & 10 \\
\hline 18 & Quantidade mensal coletada seletivamente (t/mês) & 52 & 5 & 8,13 & 2,08 & 3 & 10 \\
\hline 21 & $\begin{array}{l}\text { Renda média mensal por catador autônomo } \\
\text { (R\$/catador/mês) }\end{array}$ & 52 & 5 & 8,13 & 1,67 & 4 & 10 \\
\hline 25 & Eficiência da coleta seletiva $(\mathrm{t} / \mathrm{km} / \mathrm{h})$ & 55 & 2 & 8,16 & 2,16 & 1 & 10 \\
\hline 23 & Custo total da coleta seletiva (R\$/t) & 53 & 4 & 8,32 & 2,05 & 2 & 10 \\
\hline 2 & $\begin{array}{l}\text { Índice de Recuperação de Materiais Recicláveis - } \\
\text { IRMR (\%) }\end{array}$ & 53 & 4 & 8,51 & 1,93 & 2 & 10 \\
\hline 1 & Cobertura do atendimento (hab) & 54 & 3 & 8,54 & 2,13 & 3 & 10 \\
\hline
\end{tabular}

* notas variando de

1 a 3 - pouca importância; $\quad 4$ a 7 - média importância e

8 a 10 - muita importância. 
A seguir, são apresentados os indicadores listados em função das notas recebidas, enquadrando-se como média importância (gráfico 11) e de muita importância (gráfico 12). Com base nos resultados da pesquisa, não houve indicadores considerados de pouca importância pelos entrevistados.

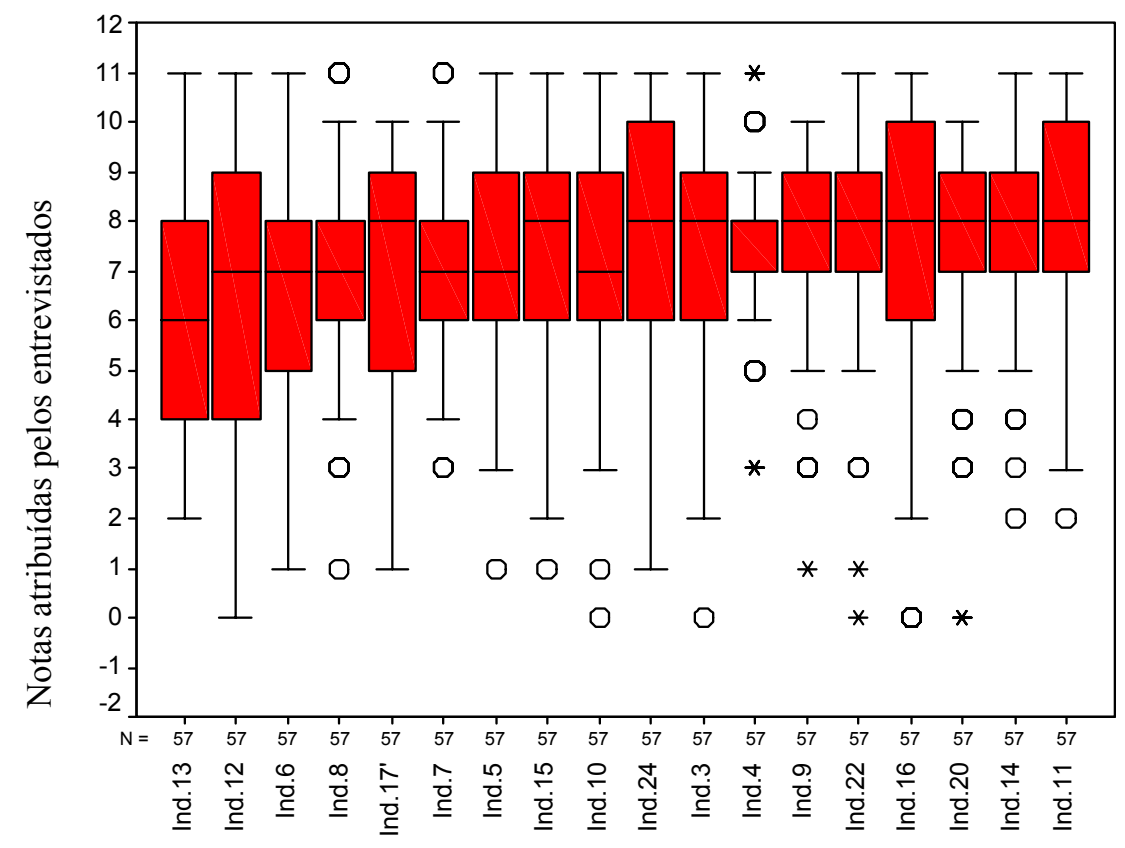

Gráfico 11 - Box Plot dos indicadores de média importância.

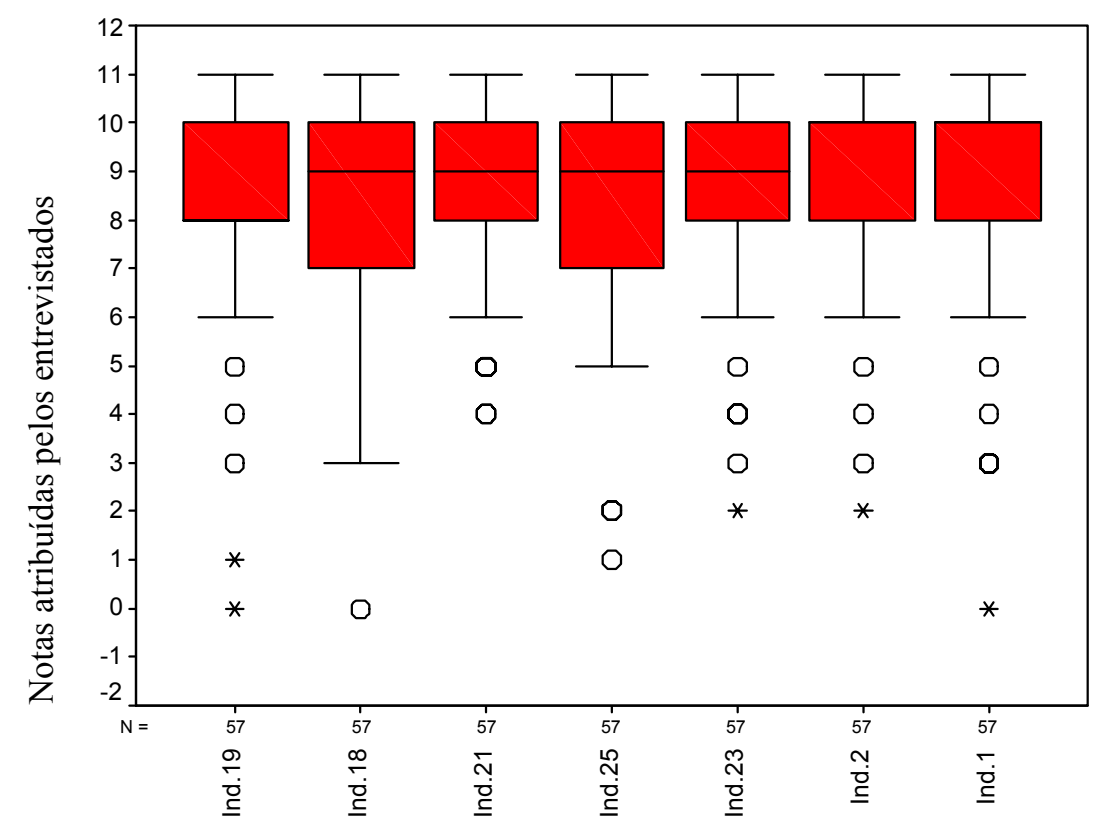

Gráfico 12 - Box Plot dos indicadores de muita importância.

A seguir apresentam-se os gráficos de média (Erro Bar) 13 e 14. 


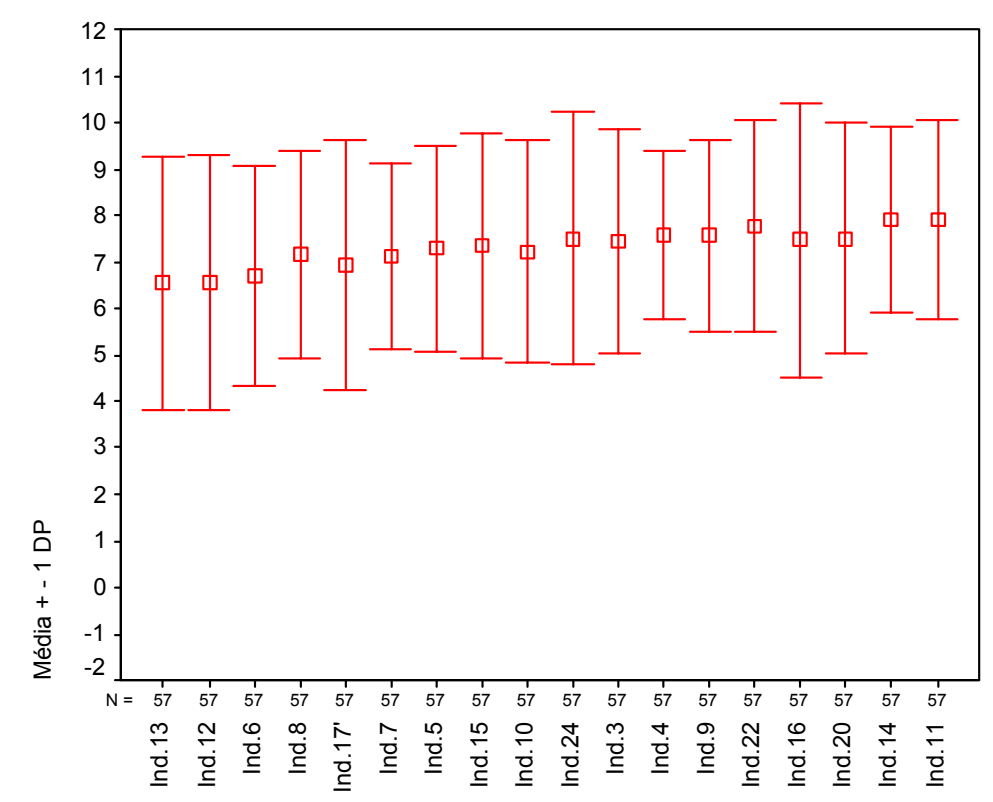

Gráfico 13 - Erro Bar dos indicadores de média importância.

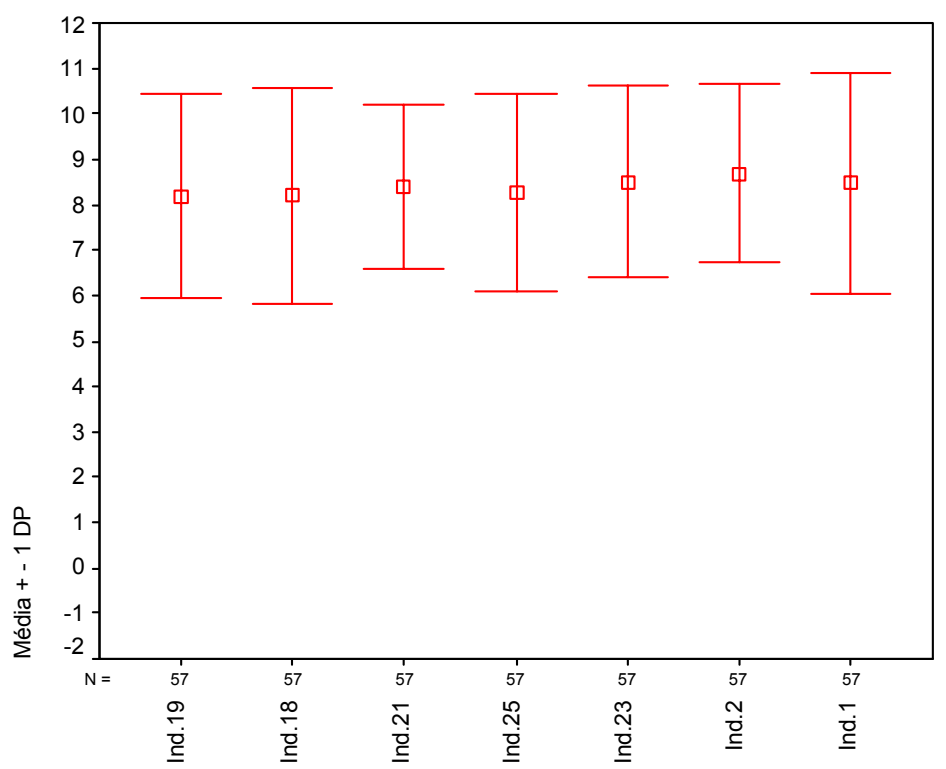

Gráfico 14 - Erro Bar dos indicadores de muita importância.

Pelos gráficos 11, 12, 13 e 14 nota-se que os indicadores, considerados de média e de muita importância, segundo avaliação média atribuída pelos entrevistados, quando avaliados em um grau de importância inferior, têm estas avaliações consideradas discrepantes. Os indicadores de média importância que apresentaram avaliações 
discrepantes (gráfico 11) foram: despesa com marketing e educação ( $\mathrm{R} \$ /$ hab/ano), Var 3; freqüência média de coletas ( ${ }^{\circ}$ de coletas/ semana), Var 9; percentual mensal de reclamações/não conformidade, Var 15; preço médio de comercialização do "mix" de material reciclável $(\mathrm{R} \$ / \mathrm{t})$, Var 8; quantidade mensal de catadores autônomos envolvidos na organização (catadores/mês), Var 7; relação receita/despesa, Var 5; produção média de recicláveis por $\operatorname{PEV~(t/PEV),~Var~10;~investimento~per~capita~}$ anual no programa (R\$/ hab/ano), Var 4; eficiência de mão-de-obra de triagem (t/trabalhador/hora), Var 22; percentual de resíduos orgânicos no lixo da coleta seletiva (\%), Var 16; quantidade de itens de materiais recicláveis comercializados (un), Var 20; custo mensal de operação da coleta e transporte (R\$/t), Var 14; e percentual de resíduos recicláveis no lixo da coleta regular (\%), Var 11. Todos indicadores de muita importância, apresentaram avaliações discrepantes, ou seja, apresentaram pontos fora das linhas que delimitam os valores mais altos e baixos da variação (extremos) de notas atribuídas aos indicadores pelos entrevistados, conforme gráfico 12 .

Em termos gerais, com base nos resultados dos testes estatísticos tem-se 7 indicadores, dentre os 25 apresentados no questionário, classificados como muito importantes pelos entrevistados.

A seguir, apresentam-se os indicadores classificados como muito importantes, em ordem decrescente de avaliação:

$1^{\text {o }}$. Cobertura do atendimento (hab)

$2^{\circ}$. Índice de Recuperação de Materiais Recicláveis - IRMR (\%)

$3^{\circ}$. Custo total da coleta seletiva $(\mathrm{R} \$ / \mathrm{t})$

$4^{\mathrm{o}}$. Eficiência da coleta seletiva $(\mathrm{t} / \mathrm{km} / \mathrm{h})$

$5^{\circ}$. Renda média mensal por catador autônomo (R $\$ /$ catador/mês)

$6^{\circ}$. Quantidade mensal coletada seletivamente ( $\left.\mathrm{t} / \mathrm{mês}\right)$

$7^{\circ}$. Custo de triagem $(\mathrm{R} \$ / \mathrm{t})$

De maneira geral, observa-se que o grupo de indicadores selecionados como de muita importância tem caráter mais operacional, sendo que as questões de custo e renda apareceram em 3 dentre esses indicadores, enquanto que a questão da escala da coleta 
seletiva está representada nos indicadores: cobertura de atendimento e quantidade mensal coletada seletivamente.

Os aspectos operacionais da coleta seletiva estão relacionados ao indicador eficiência da coleta seletiva, enquanto que o IRMR refere-se, indiretamente, aos resultados da participação da população na coleta seletiva. Nesses indicadores, não foram contemplados os aspectos de qualidade do serviço e mobilização da comunidade.

Acredita-se que a ausência de indicadores relativos à qualidade do serviço, mobilização e, em menor escala, referentes à participação da população no grupo de maior importância possa ser atribuída ao perfil dos entrevistados, em sua maioria profissionais com visão mais técnica da questão e à pouca tradição existente no país em quantificar informações que, a princípio, teriam perfil mais qualitativo.

Em continuidade, foi aplicada ainda a Análise Fatorial aos 25 indicadores, tratados como 25 variáveis, com o objetivo de identificar variáveis ou fatores que apresentaram padrão de correlação dentro do conjunto de variáveis observadas.

\section{Análise Multivariada Fatorial}

No desenvolvimento da análise de fator dos 25 indicadores, foi gerada uma matriz de correlação entre as variáveis e os seus fatores, com objetivo de identificar conjuntos interrelacionados de variáveis.

Para cada variável analisada, apresentou-se a matriz de comunalidade e foi feita a resolução por rotação (Varimax), para se obter resultados mais interpretáveis. O método de extração de fatores foi o de análise dos componentes principais, para autovalor maior ou igual a 1 .

Assim, mediante o processamento de análise fatorial, examinando as variáveis e seus pesos fatoriais, foi possível observar agrupamentos em oito fatores:

- Fator 1 - Participação na Coleta Seletiva

- Fator 2 - Escala da Coleta Seletiva

- Fator 3 - Custo da Coleta Seletiva

- Fator 4 - Operação da Coleta Seletiva

- Fator 5 - Coleta Seletiva por Organização de Trabalhadores Autônomos

- Fator 6 e 8 - Coleta Seletiva por Postos de Entrega Voluntária 
A tabela 3 apresenta o agrupamento dos 25 indicadores de coleta seletiva identificados, em 8 fatores, segundo Análise Multivariada Fatorial.

Ainda quanto à tabela 3 , tem-se no método adotado os pesos fatoriais variam de -1 até +1 , e quanto mais próximo dos extremos, maior a influência da variável na composição do fator.

Vale ressaltar que na análise foram constatados pesos fatoriais acima de 0,40, indicando a representatividade da variável na composição dos fatores. Sendo que, os 25 indicadores selecionados e tratados como varáveis, mostraram-se representativos perante o processo adotado.

Observa-se que a ordem dos fatores gerados pelo aplicativo revela seu grau de importância, bem como a correlação das variáveis inerentes a estes fatores, na perspectiva dos entrevistados, sendo que num mesmo fator, a ordem de importância das variáveis é dada pela carga fatorial, logo a de maior carga fatorial é respectivamente a de maior importância. 
Tabela 3 - Agrupamento dos indicadores de coleta seletiva em 8 fatores, segundo Análise Multivariada Fatorial.

\begin{tabular}{|c|c|c|c|}
\hline \multirow{2}{*}{$\begin{array}{c}\text { Ordem } \\
\text { do Fator }\end{array}$} & \multicolumn{2}{|r|}{ Indicadores } & \multirow{2}{*}{$\begin{array}{c}\begin{array}{c}\text { Carga } \\
\text { Fatorial }\end{array} \\
0,8222 \\
\end{array}$} \\
\hline & 2 & Índice de Recuperação de Materiais Recicláveis - IRMR (\%) & \\
\hline & 5 & Relação Receita/Despesa & 0,4669 \\
\hline & 11 & Percentual de resíduos recicláveis no lixo da coleta regular (\%) & 0,7475 \\
\hline & 16 & Percentual de resíduos orgânicos no lixo da coleta seletiva (\%) & 0,8086 \\
\hline \multirow{4}{*}{2} & 1 & Cobertura do atendimento (hab) & 0,6345 \\
\hline & 3 & Despesa com marketing e educação (R\$/hab/ano) & 0,8414 \\
\hline & 4 & Investimento per capita anual no programa (R\$/ hab/ano) & 0,5973 \\
\hline & 18 & Quantidade mensal coletada seletivamente (t/mês) & 0,5934 \\
\hline \multirow{5}{*}{3} & 14 & Custo mensal de operação da coleta e transporte $(\mathrm{R} \$ / \mathrm{t})$ & 0,8453 \\
\hline & 15 & Percentual mensal de reclamações/não conformidades (\%) & 0,6875 \\
\hline & 19 & Custo de triagem $(\mathrm{R} \$ \mathbf{t})$ & 0,5177 \\
\hline & 24 & Receita apurada em vendas (R\$/ mês) & 0,5483 \\
\hline & 25 & Eficiência da coleta seletiva $(\mathrm{t} / \mathrm{km} / \mathbf{h})$ & 0,4774 \\
\hline \multirow{3}{*}{4} & 20 & Quantidade de itens de materiais recicláveis comercializados (un) & 0,5099 \\
\hline & 22 & Eficiência de mão-de-obra de triagem (t/trabalhador/hora) & 0,7167 \\
\hline & 23 & Custo total da coleta seletiva $(\mathrm{R} \$ / \mathrm{t})$ & 0,6604 \\
\hline \multirow{3}{*}{5} & 7 & $\begin{array}{l}\text { Quantidade mensal de catadores autônomos envolvidos na } \\
\text { organização (catadores/mês) }\end{array}$ & 0,5641 \\
\hline & 13 & Percentual de rotatividade de catadores autônomos (\%) & 0,8111 \\
\hline & 21 & Renda média mensal por catador autônomo (R\$/catador/mês) & 0,6482 \\
\hline \multirow{3}{*}{6} & 6 & Quantidade de PEVs instalados (un) & 0,5635 \\
\hline & 9 & Freqüência média de coletas ( $n^{\circ}$ de coletas/ semana) & 0,8038 \\
\hline & 17 & Índice mensal de vandalismo PEVs (\%) & 0,6490 \\
\hline \multirow{2}{*}{7} & 8 & Preço médio de comercialização do mix de material reciclável (R\$/ t) & 0,6777 \\
\hline & 12 & Densidade de coleta $(t / h)$ & 0,7361 \\
\hline 8 & 10 & Produção média de recicláveis por PEV (t/PEV) & 0,7798 \\
\hline
\end{tabular}

A variabilidade total das variáveis nos fatores, quando extraídos pelo método de Análise dos Componentes Principais, correspondendo à variância total explicada, é 
apresentada na tabela 4 . Observa-se que $71,49 \%$ dos dados (percentual acumulado) foram explicados, quando se considerou como "alto" os valores iguais ou maiores que 1,0 .

Tabela 4 - Variância total explicada por fator, segundo Análise Multivariada Fatorial.

\begin{tabular}{|c|c|c|c|c|c|c|}
\hline \multirow{2}{*}{ Fatores } & \multicolumn{6}{|c|}{ Variância Total Explicada } \\
\cline { 2 - 7 } & \multicolumn{3}{|c|}{ Pesos Extraídos } & \multicolumn{3}{c|}{ Pesos Rotacionados } \\
\cline { 2 - 7 } & Total & \% & \% Acum. & Total & \% & \% Acum. \\
\hline $\mathbf{1}$ & 5,69 & 22,76 & 22,76 & 3,21 & 12,85 & 12,85 \\
$\mathbf{2}$ & 2,57 & 10,29 & 33,05 & 2,57 & 10,27 & 23,12 \\
$\mathbf{3}$ & 2,16 & 8,65 & 41,70 & 2,40 & 9,59 & 32,70 \\
$\mathbf{4}$ & 1,98 & 7,91 & 49,61 & 2,38 & 9,51 & 42,22 \\
$\mathbf{5}$ & 1,62 & 6,49 & 56,10 & 2,03 & 8,11 & 50,32 \\
$\mathbf{6}$ & 1,44 & 5,76 & 61,86 & 1,94 & 7,74 & 58,07 \\
$\mathbf{7}$ & 1,27 & 5,10 & 66,95 & 1,71 & 6,85 & 64,92 \\
$\mathbf{8}$ & 1,13 & 4,53 & 71,49 & 1,64 & 6,57 & $\mathbf{7 1 , 4 9}$ \\
\hline
\end{tabular}

Diante dos resultados obtidos pela análise fatorial, verificou-se a existência de correlação entre as variáveis que se assemelham dentro dos fatores, por apresentarem comportamentos comuns.

A seguir, apresentam-se a análise e a correlação dos fatores obtidos:

- Fator 1 - Participação na Coleta Seletiva

O Fator 1 engloba principalmente as variáveis índice de recuperação de materiais recicláveis, Var 2; percentual de resíduos recicláveis no lixo da coleta regular, Var 11; e percentual de resíduos orgânicos no lixo da coleta seletiva, Var 16, que relacionamse com a participação da população na coleta seletiva.

Esta relação tem significativa importância e aplicação prática, face às dificuldades de se apurar informações sobre a participação da população em programas de coleta seletiva.

A Var 5 (relação receita/despesa) aparece deslocada no grupo. 
- Fator 2 - Escala da Coleta Seletiva

O Fator 2 engloba as variáveis: cobertura de atendimento, Var 1, e quantidade mensal coletada seletivamente, Var 18, as quais possuem características comuns, referentes à escala e à amplitude do programa de coleta seletiva, e resultam em informações objetivas e de fácil entendimento, sobre o seu desempenho.

As variáveis investimento per capita anual no programa, Var 4, e despesa com marketing e educação, Var 3, possuem relação indireta com a escala da coleta seletiva. A escala da coleta seletiva não cresce, necessariamente, na mesma proporção dos investimentos e despesas realizadas.

- Fator 3 - Custo da Coleta Seletiva

O Fator 3 engloba as variáveis custo mensal da coleta seletiva, Var 14; custo de triagem, Var 19 e receita apurada em vendas, Var 24, as quais apresentam características relacionadas aos aspectos de custo dos programas de coleta seletiva.

A eficiência da coleta seletiva, Var 25, refere-se à operação da coleta seletiva que, por sua vez, apresenta relação direta com o custo do programa.

O percentual mensal de reclamações e não conformidades, Var 15, apresenta-se deslocado no grupo.

- Fator 4 - Operação da Coleta Seletiva

O fator 4 inclui a quantidade de itens de materiais recicláveis comercializados, Var 20, e a eficiência da mão-de-obra de triagem, Var 22, que são importantes para a avaliação da operação do programa de coleta seletiva. A variável custo da coleta seletiva, Var 23, encontra-se deslocada no grupo.

- Fator 5 - Coleta Seletiva por Organização de Trabalhadores Autônomos

O fator 5 inclui as variáveis: quantidade mensal de catadores autônomos envolvidos na organização, Var 7, percentual de rotatividade de catadores autônomos, Var 13, e a renda média por catador autônomo, Var 21. Este conjunto representa a base da análise de programas de coleta seletiva pela modalidade Organização de Trabalhadores Autônomos da reciclagem. 
- Fator 6 e 8 - Coleta Seletiva por Postos de Entrega Voluntária

O fator 6 engloba as variáveis: quantidade de PEVs instalados, Var 6, e índice mensal de vandalismo em PEVs, Var 17, com características típicas de coleta seletiva por Postos de Entrega Voluntária. Inclui, ainda, a Var 9 (freqüência média de coletas), que tem caráter geral e, também, aplica-se a outras modalidades de coleta seletiva.

O fator 8, que conta com a variável Var 10 (produção média de recicláveis por PEVs) também se refere à coleta seletiva por Postos de Entrega Voluntária.

Não foi possível definir um título único para o Fator 7, uma vez que este engloba uma variável de custo, que é a Var 8 (preço médio de comercialização do "mix" de material reciclável) e outra operacional da coleta seletiva, que é a Var 12 (densidade de coleta).

Assim, os fatores de 1 a 4 e o 7 referem-se a programas de coleta seletiva em geral e os fatores 5, 6 e 8 a programas de coleta seletiva para modalidades específicas.

A partir dos resultados do tratamento dos dados, desenvolvido mediante Análise Multivariada Fatorial, que refletem a avaliação de 57 profissionais, verifica-se que o grupo de indicadores de coleta seletiva, que se busca estabelecer, deve contemplar os aspectos: escala; operação; custo; e participação da população.

Dando continuidade ao processo de Estabelecimento de Grupo de Indicadores de Coleta Seletiva, partiu-se para análise qualitativa dos indicadores avaliados, considerando os critérios validade, confiabilidade, representatividade e oportunidade, utilizando-se a Técnica Delphi.

\section{Técnica Delphi}

A técnica Delphi foi utilizada com o objetivo de conjugar a experiência da equipe técnica da prefeitura de Vitória na definição do grupo de indicadores de referência em Programas de Coleta Seletiva.

Todos os 7 profissionais participantes da técnica apresentavam nível superior: 5 eram graduados em engenharia civil, 1 em engenharia agronômica e 1 em biomedicina., dos quais $42,9 \%$ apresentavam mestrado e $28,2 \%$, curso de especialização. Destes 
técnicos, 5 ocupavam cargo de chefia, denotando poder de decisão quanto à gestão da limpeza pública de Vitória.

Partindo-se dos critérios de avaliação adotados para aplicação do método: VALIDADE, CONFIABILIDADE, REPRESENTATIVIDADE, OPORTUNIDADE, a importância dos indicadores resultou das notas (variando de 1 a 10) atribuídas pelos participantes da técnica. Da mesma forma que na análise descritiva apresentada anteriormente, quanto maior a nota final, obtida pelo indicador, maior a sua importância. Na tabela 5 e nos gráficos 15, 16, 17 e 18 são apresentados os resultados da avaliação dos indicadores para o critério de avaliação VALIDADE. 
Tabela 5 - Resultados das avaliações dos indicadores, feitas pelos entrevistados agrupados, para o critério de avaliação VALIDADE, segundo grau de importância atribuída

\begin{tabular}{|c|c|c|c|c|c|c|c|}
\hline Var & INDICADOR & \begin{tabular}{c|c}
$\mathrm{N}$ \\
Válido
\end{tabular} & $\begin{array}{c}\text { Não Sabe/ } \\
\text { Não } \\
\text { Respondeu }\end{array}$ & Média & $\begin{array}{l}\text { Desvio } \\
\text { Padrão }\end{array}$ & $\begin{array}{l}\text { V. } \\
\text { Min. }\end{array}$ & $\begin{array}{l}\text { V. } \\
\text { Máx. }\end{array}$ \\
\hline \multicolumn{8}{|c|}{ Média Importância * } \\
\hline 13 & $\begin{array}{l}\text { Percentual de rotatividade de catadores autônomos } \\
(\%)\end{array}$ & 7 & 0 & 4,00 & 0,82 & 3 & 5 \\
\hline 12 & Densidade de coleta $(\mathrm{t} / \mathrm{h})$ & 7 & 0 & 6,14 & 0,38 & 6 & 7 \\
\hline 7 & $\begin{array}{l}\text { Quantidade mensal de catadores autônomos } \\
\text { envolvidos na organização (catadores/mês) }\end{array}$ & 7 & 0 & 6,71 & 0,95 & 5 & 8 \\
\hline 22 & $\begin{array}{l}\text { Eficiência de mão-de-obra de } \\
(\mathrm{t} / \text { trabalhador/hora) }\end{array}$ & 7 & 0 & 6,86 & 1,57 & 6 & 10 \\
\hline 17 & Índice mensal de vandalismo PEVs (\%) & 7 & 0 & 7,43 & 1,13 & 6 & 9 \\
\hline 21 & $\begin{array}{l}\text { Renda média mensal por catador autônomo } \\
\text { (R\$/catador/mês) }\end{array}$ & 7 & 0 & 7,71 & 1,50 & 5 & 9 \\
\hline 5 & Relação Receita/Despesa & 7 & 0 & 7,86 & 2,41 & 5 & 10 \\
\hline \multicolumn{8}{|c|}{ Muito Imnortante * } \\
\hline 4 & $\begin{array}{l}\text { Investimento per capita anual no programa (R\$/ } \\
\text { hab/ano) }\end{array}$ & 7 & 0 & 8,00 & 1,29 & 6 & 10 \\
\hline 11 & $\begin{array}{l}\text { Percentual de resíduos recicláveis no lixo da coleta } \\
\text { regular }(\%)\end{array}$ & 7 & 0 & 8,00 & 1,00 & 7 & 10 \\
\hline 9 & Freqüência média de coletas ( $n^{\circ}$ de coletas/ semana) & 7 & 0 & 8,14 & 0,69 & 7 & 9 \\
\hline 3 & Despesa com marketing e educação (R\$/hab/ano) & 7 & 0 & 8,14 & 1,21 & 7 & 10 \\
\hline 8 & $\begin{array}{l}\text { Preço médio de comercialização do mix de material } \\
\text { reciclável }(\mathrm{R} \$ / \mathrm{t})\end{array}$ & 7 & 0 & 8,14 & 0,90 & 7 & 10 \\
\hline 25 & Eficiência da coleta seletiva $(\mathrm{t} / \mathrm{km} / \mathrm{h})$ & 7 & 0 & 8,29 & 1,50 & 6 & 10 \\
\hline 24 & Receita apurada em vendas (R\$/ mês) & 7 & 0 & 8,29 & 2,21 & 5 & 10 \\
\hline 1 & Cobertura do atendimento (hab) & 7 & 0 & 8,43 & 0,79 & 8 & 10 \\
\hline 14 & $\begin{array}{l}\text { Custo mensal de operação da coleta e transporte } \\
(\mathrm{R} \$ / \mathrm{t})\end{array}$ & 7 & 0 & 8,43 & 1,27 & 7 & 10 \\
\hline 15 & $\begin{array}{l}\begin{array}{l}\text { Percentual mensal de } \\
\text { conformidades }(\%)\end{array} \\
\end{array}$ & 7 & 0 & 8,43 & 1,27 & 7 & 10 \\
\hline 19 & Custo de triagem $(\mathrm{R} \$ / \mathrm{t})$ & 7 & 0 & 8,43 & 1,51 & 6 & 10 \\
\hline 2 & $\begin{array}{l}\text { IRMR - Índice de Recuperação de Materiais } \\
\text { Recicláveis (\%) }\end{array}$ & 7 & 0 & 8,57 & 1,62 & 6 & 10 \\
\hline 6 & Quantidade de PEVs instalados (un) & 7 & 0 & 8,71 & 1,38 & 7 & 10 \\
\hline 16 & $\begin{array}{l}\text { Percentual de resíduos orgânicos no lixo da coleta } \\
\text { seletiva (\%) }\end{array}$ & 7 & 0 & 8,71 & 1,11 & 7 & 10 \\
\hline 10 & Produção média de recicláveis por PEV (t/PEV) & 7 & 0 & 9,00 & 1,53 & 6 & 10 \\
\hline 18 & Quantidade mensal coletada seletivamente ( $\mathrm{t} / \mathrm{mês}$ ) & 7 & 0 & 9,00 & 1,29 & 7 & 10 \\
\hline 20 & $\begin{array}{l}\text { Quantidade de itens de materiais recicláveis } \\
\text { comercializados (un) }\end{array}$ & 7 & 0 & 9,14 & 0,90 & 8 & 10 \\
\hline 23 & Custo total da coleta seletiva $(\mathrm{R} \$ / \mathrm{t})$ & 7 & 0 & 9,14 & 1,21 & 7 & 10 \\
\hline
\end{tabular}

* notas variando de

1 a 3 - pouca importância; 


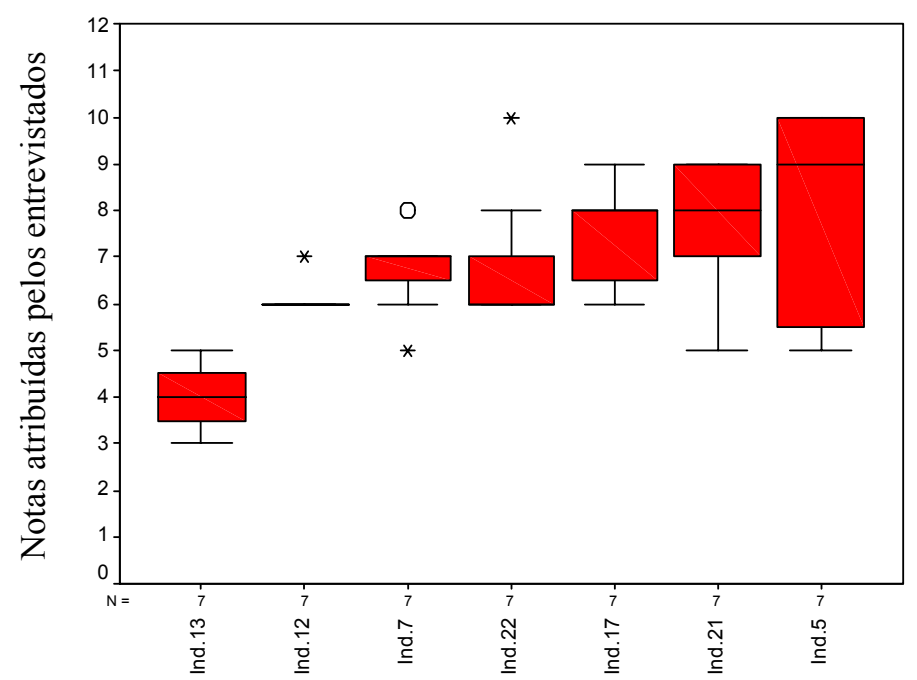

Gráfico 15 - Box Plot dos indicadores de média importância para o critério de avaliação VALIDADE

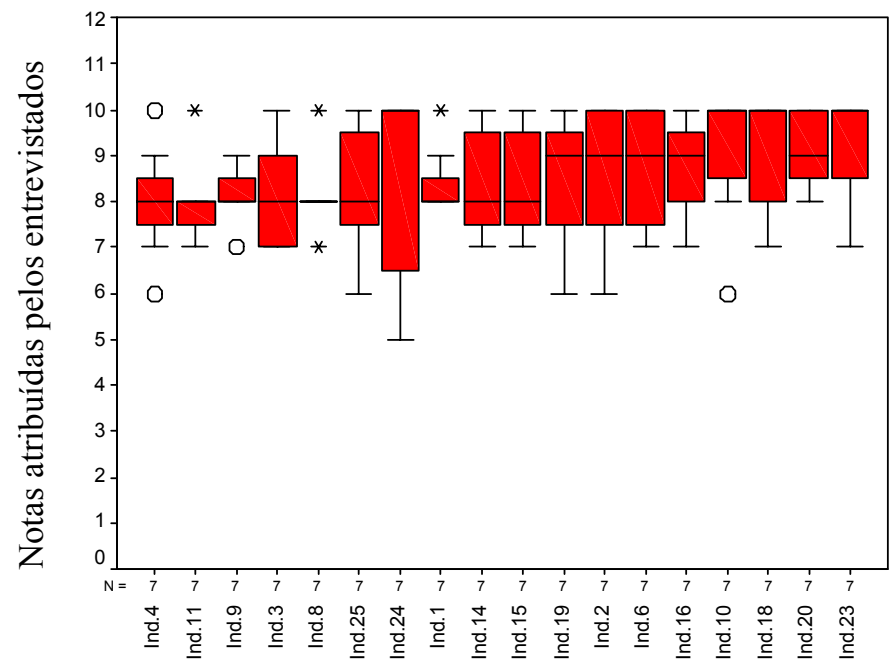

Gráfico 16 - Box Plot dos indicadores de muita importância para o critério de avaliação VALIDADE. 


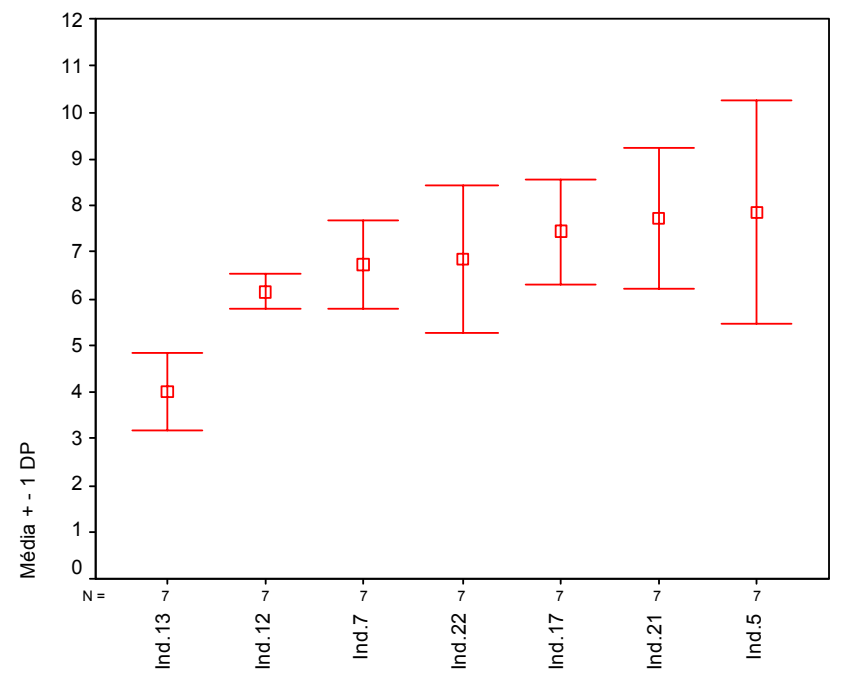

Gráfico 17 - Erro Bar dos indicadores de média importância para o critério de avaliação VALIDADE.

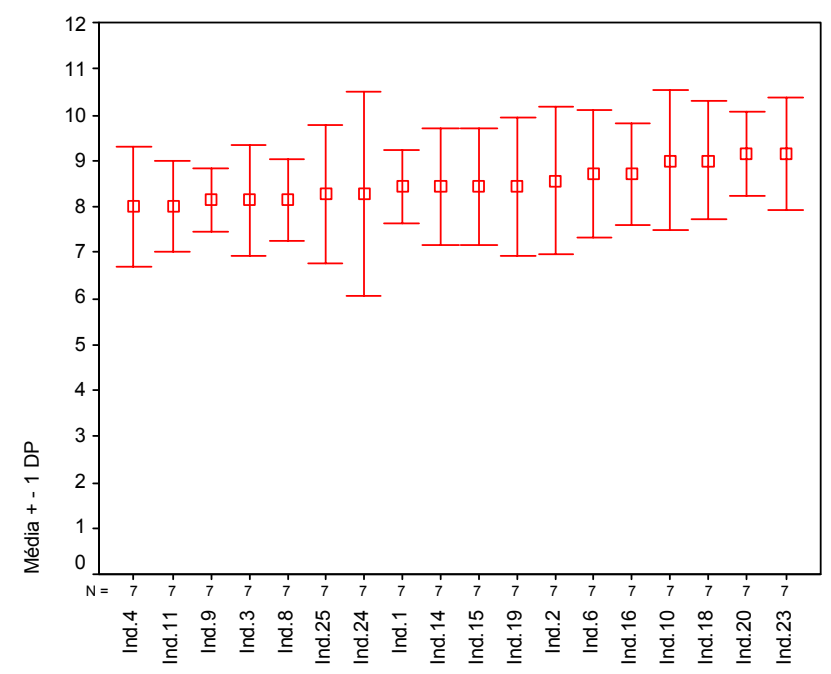

Gráfico 18 - Erro Bar dos indicadores de muita importância para o critério de avaliação VALIDADE.

Para o critério VALIDADE, foi solicitado que as notas fossem atribuídas aos indicadores, considerando-se a sua adequação para medir ou representar, sinteticamente, o desempenho de programas de coleta seletiva. 
A partir da tabela 5 observa-se que, da mesma forma que na Análise Descritiva, a avaliação média dos indicadores varia entre os graus de média importância (4 a 7) e muita importância (8 a 10).

O indicador percentual de rotatividade de catadores autônomos (\%), Var 13, apresentou menor avaliação média $(4,00)$ e o indicador custo total da coleta seletiva $(\mathrm{R} \$ / \mathrm{t})$, Var 23, maior avaliação média $(9,14)$. Quanto à variação em torno da média, tem-se o indicador densidade de coleta $(\mathrm{t} / \mathrm{h})$, Var 12 , com menor variação $(0.36)$, em relação aos demais indicadores, e o indicador relação receita/despesa, Var 5, com maior variação. Os demais indicadores apresentaram desvio padrão entre 0,69 e 2,21. Tais resultados estão coerentes com o perfil do grupo de técnicos participantes da técnica Delphi, com maior vivência em programas de coleta seletiva nas modalidades PEVs e porta a porta, gerenciados pelo poder público municipal e desenvolvidos em maior escala em relação a iniciativas comunitárias e de organizações sociais.

O critério CONFIABILIDADE refere-se à garantia de obtenção de resultados semelhantes quando o indicador é aplicado repetidas vezes. A seguir, apresenta-se na tabela 6 e nos gráficos 19, 20, 21 e 22 a descrição dos resultados da avaliação dos indicadores para o critério de avaliação CONFIABILIDADE.

$\mathrm{Na}$ tabela 6 observa-se que de acordo com a avaliação média atribuída pelos entrevistados, os 25 indicadores agrupam-se entre média importância (notas entre 4 a 7) e muita importância (notas entre 8 a 10), tendo o indicador percentual de rotatividade de catadores autônomos (\%), Var 13, a menor avaliação média $(4,00)$ e o indicador preço médio de comercialização do mix de material reciclável (R\$/t), Var 8 , maior avaliação média $(9,14)$. O indicador percentual de resíduos recicláveis no lixo da coleta regular (\%), Var 11, apresentou média igual a 8,00 e menor variação em torno da média, em relação aos demais. O indicador relação receita/despesa, Var 5, apresentou maior variação em torno da média $(2,36)$. Os demais indicadores apresentaram desvio padrão variando entre 0,69 e 2,34. 
Tabela 6 - Resultados das avaliações dos indicadores feita pelos entrevistados agrupados para o critério de avaliação CONFIABILIDADE, segundo grau de importância atribuída

\begin{tabular}{|c|c|c|c|c|c|c|c|}
\hline Var & INDICADOR & $\mathbf{N}$ & \begin{tabular}{|l} 
Não Sabe/ \\
Não \\
Respondeu
\end{tabular} & Média & $\begin{array}{l}\text { Desvio } \\
\text { Padrão }\end{array}$ & $\begin{array}{l}\text { V. } \\
\text { Min. }\end{array}$ & $\begin{array}{l}\text { V. } \\
\text { Máx. }\end{array}$ \\
\hline \multicolumn{8}{|c|}{ Média Importância } \\
\hline 13 & $\begin{array}{l}\text { Percentual de rotatividade de catadores autônomos } \\
(\%)\end{array}$ & 7 & 0 & 4,00 & 1,00 & 3 & 5 \\
\hline 22 & $\begin{array}{l}\text { Eficiência de mão-de-obra de triagem } \\
\text { (t/trabalhador/hora) }\end{array}$ & 7 & 0 & 6,57 & 1,40 & 5 & 9 \\
\hline 1 & Cobertura do Atendimento (hab) & 7 & 0 & 7,29 & 0,95 & 6 & 9 \\
\hline 7 & $\begin{array}{l}\text { Quantidade mensal de catadores autônomos } \\
\text { envolvidos na organização (catadores/mês) }\end{array}$ & 7 & 0 & 7,43 & 0,79 & 7 & 9 \\
\hline 5 & Relação Receita/Despesa & 7 & 0 & 7,71 & 2,36 & 5 & 10 \\
\hline 21 & $\begin{array}{l}\text { Renda média mensal por catador autônomo } \\
\text { (R\$/catador/mês) }\end{array}$ & 7 & 0 & 7,71 & 1,25 & 6 & 10 \\
\hline 3 & Despesa com marketing e educação (R\$/hab/ano) & 7 & 0 & 7,71 & 1,25 & 6 & 10 \\
\hline \multicolumn{8}{|c|}{ Muito Importante } \\
\hline 11 & $\begin{array}{l}\text { Percentual de resíduos recicláveis no lixo da coleta } \\
\text { regular }(\%)\end{array}$ & 7 & 0 & 8,00 & 0,58 & 7 & 9 \\
\hline 17 & Índice mensal de vandalismo PEVs (\%) & 7 & 0 & 8,00 & 1,91 & 5 & 10 \\
\hline 24 & Receita apurada em vendas (R\$/ mês) & 7 & 0 & 8,14 & 2,34 & 5 & 10 \\
\hline 19 & Custo de triagem $(\mathrm{R} \$ / \mathrm{t})$ & 7 & 0 & 8,29 & 1,80 & 5 & 10 \\
\hline 25 & Eficiência da coleta seletiva $(\mathrm{t} / \mathrm{km} / \mathrm{h})$ & 7 & 0 & 8,29 & 1,38 & 6 & 10 \\
\hline 4 & $\begin{array}{l}\text { Investimento per capita anual no programa (R\$/ } \\
\text { hab/ano) }\end{array}$ & 7 & 0 & 8,43 & 1,40 & 6 & 10 \\
\hline 10 & Produção média de recicláveis por PEV (t/PEV) & 7 & 0 & 8,43 & 1,62 & 6 & 10 \\
\hline 15 & $\begin{array}{l}\text { Percentual mensal de reclamações/não } \\
\text { conformidades }(\%)\end{array}$ & 7 & 0 & 8,43 & 1,13 & 7 & 10 \\
\hline 2 & $\begin{array}{l}\text { Índice de Recuperação de Materiais Recicláveis - } \\
\text { IRMR (\%) }\end{array}$ & 7 & 0 & 8,57 & 1,62 & 6 & 10 \\
\hline 12 & Densidade de Coleta $(\mathrm{t} / \mathrm{h})$ & 7 & 0 & 8,57 & 0,98 & 7 & 10 \\
\hline 16 & $\begin{array}{l}\text { Percentual de resíduos orgânicos no lixo da coleta } \\
\text { seletiva }(\%)\end{array}$ & 7 & 0 & 8,57 & 1,13 & 7 & 10 \\
\hline 6 & Quantidade de PEVs instalados (un) & 7 & 0 & 8,71 & 1,70 & 6 & 10 \\
\hline 14 & $\begin{array}{l}\text { Custo mensal de Operação da Coleta e Transporte } \\
(\mathrm{R} \$ / \mathrm{t})\end{array}$ & 7 & 0 & 8,86 & 0,90 & 8 & 10 \\
\hline 18 & Quantidade mensal coletada seletivamente (t/mês) & 7 & 0 & 8,86 & 1,07 & 8 & 10 \\
\hline 23 & Custo total da coleta seletiva (R\$/t) & 7 & 0 & 8,86 & 1,57 & 6 & 10 \\
\hline 9 & Freqüência média de coletas ( $\mathrm{n}^{\circ}$ de coletas/ semana) & 7 & 0 & 9,14 & 1,46 & 6 & 10 \\
\hline 20 & $\begin{array}{l}\text { Quantidade de itens de materiais recicláveis } \\
\text { comercializados (un) }\end{array}$ & 7 & 0 & 9,14 & 0,69 & 8 & 10 \\
\hline 8 & $\begin{array}{l}\text { Preço médio de comercialização do mix de material } \\
\text { reciclável }(\mathrm{R} \$ / \mathrm{t})\end{array}$ & 7 & 0 & 9,14 & 0,90 & 8 & 10 \\
\hline
\end{tabular}

* notas variando de

1 a 3 - pouca importância; $\quad 4$ a 7 - média importância e

8 a 10 - muita importância. 


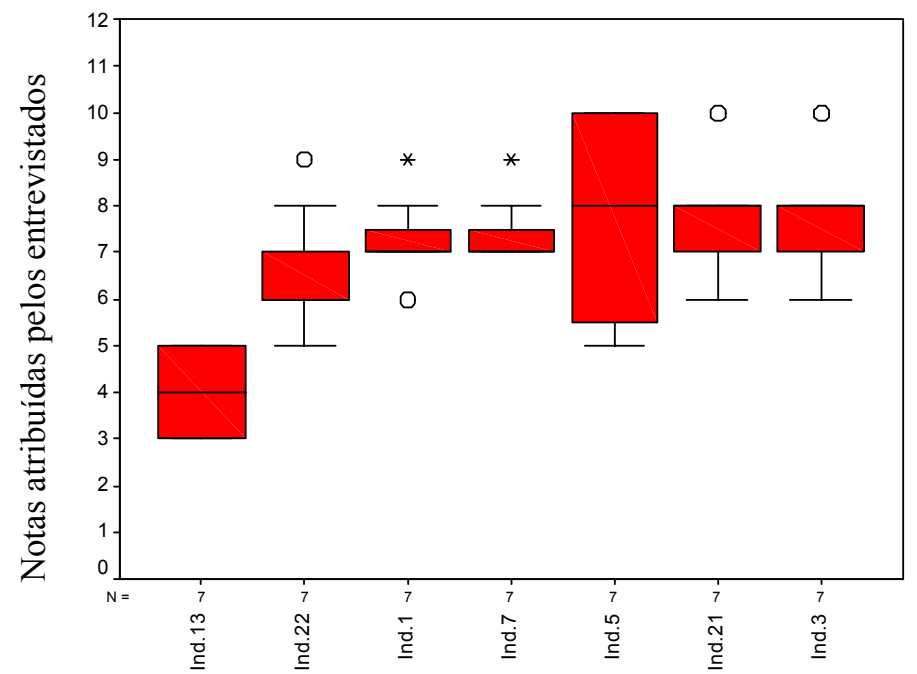

Gráfico 19 - Box Plot dos indicadores de média importância para o critério de avaliação CONFIABILIDADE.

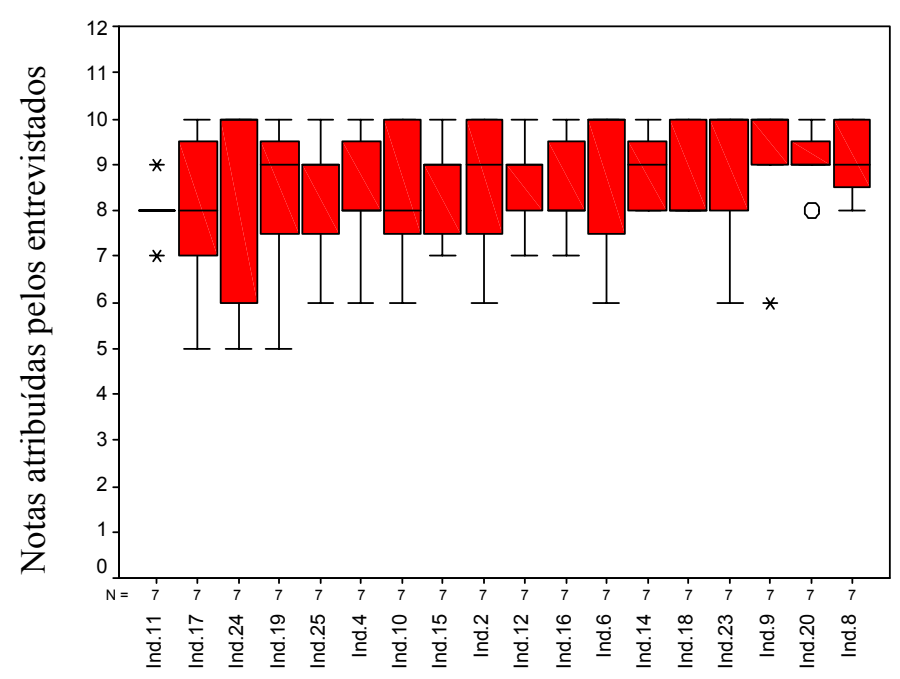

Gráfico 20 - Box Plot dos indicadores de muita importância para o critério de avaliação CONFIABILIDADE. 


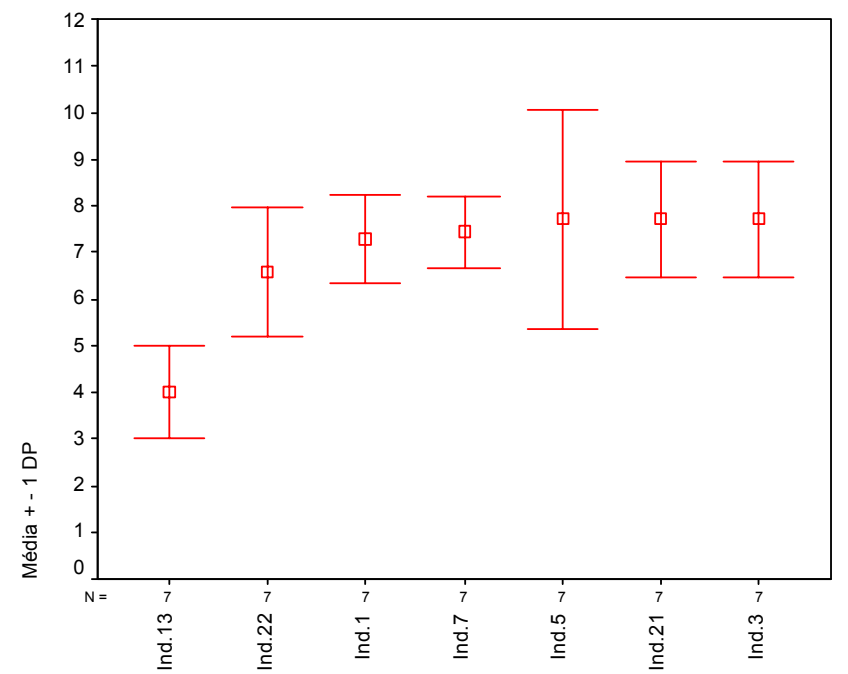

Gráfico 21 - Erro Bar dos indicadores de média importância para o critério de avaliação CONFIABILIDADE.

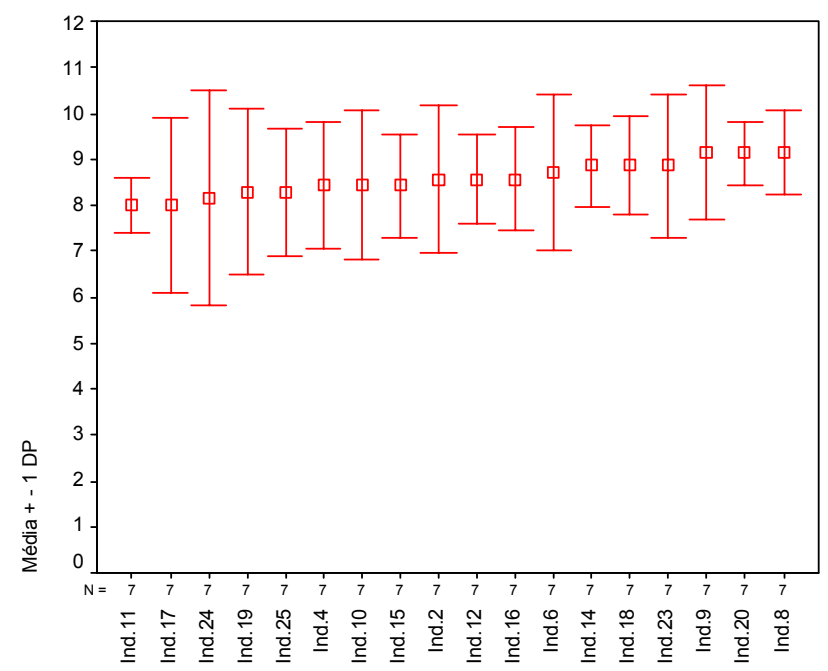

Gráfico 22 - Erro Bar dos indicadores de muita importância para o critério de avaliação CONFIABILIDADE.

Na tabela 7 e nos gráficos 23, 24, 25 e 26 tem-se a descrição dos resultados agrupados para critério de avaliação REPRESENTATIVIDADE, segundo grau de importância. 
Tabela 7 - Resultados das avaliações dos indicadores feitas pelos entrevistados agrupados para o critério de avaliação REPRESENTATIVIDADE, segundo grau de importância atribuída

\begin{tabular}{|c|c|c|c|c|c|c|c|}
\hline Var & INDICADOR & $\begin{array}{c}\mathbf{N} \\
\text { Válido }\end{array}$ & $\begin{array}{c}\text { Não Sabe/ } \\
\text { Não } \\
\text { Respondeu }\end{array}$ & Média & $\begin{array}{l}\text { Desvio } \\
\text { Padrão }\end{array}$ & $\begin{array}{l}\text { V. } \\
\text { Min. }\end{array}$ & $\begin{array}{l}\text { V. } \\
\text { Máx. }\end{array}$ \\
\hline \multicolumn{8}{|c|}{ Média Importância } \\
\hline 13 & $\begin{array}{l}\text { Percentual de rotatividade de catadores autônomos } \\
(\%)\end{array}$ & 7 & 0 & 3,86 & 0,69 & 3 & 5 \\
\hline 7 & $\begin{array}{l}\text { Quantidade mensal de catadores autônomos } \\
\text { envolvidos na organização (catadores/mês) }\end{array}$ & 7 & 0 & 5,86 & 0,69 & 5 & 7 \\
\hline 12 & Densidade de Coleta $(\mathrm{t} / \mathrm{h})$ & 7 & 0 & 6,29 & 0,49 & 6 & 7 \\
\hline 22 & $\begin{array}{l}\text { Eficiência de mão-de-obra de triagem } \\
\text { (t/trabalhador/hora) }\end{array}$ & 7 & 0 & 6,57 & 1,81 & 5 & 10 \\
\hline 1 & Cobertura do Atendimento (hab) & 7 & 0 & 7,00 & 0,82 & 6 & 8 \\
\hline 3 & Despesa com marketing e educação (R\$/hab/ano) & 7 & 0 & 7,14 & 1,57 & 5 & 10 \\
\hline 4 & $\begin{array}{l}\text { Investimento per capita anual no programa (R\$/ } \\
\text { hab/ano) }\end{array}$ & 7 & 0 & 7,43 & 1,62 & 5 & 10 \\
\hline 17 & Índice mensal de vandalismo PEVs (\%) & 7 & 0 & 7,43 & 1,40 & 5 & 9 \\
\hline 21 & $\begin{array}{l}\text { Renda média mensal por catador autônomo } \\
\text { (R\$/catador/mês) }\end{array}$ & 7 & 0 & 7,43 & 0,79 & 7 & 9 \\
\hline 25 & Eficiência da coleta seletiva $(\mathrm{t} / \mathrm{km} / \mathrm{h})$ & 7 & 0 & 7,57 & 1,62 & 6 & 10 \\
\hline 5 & Relação Receita/Despesa & 7 & 0 & 7,57 & 1,99 & 5 & 10 \\
\hline 11 & $\begin{array}{l}\text { Percentual de resíduos recicláveis no lixo da coleta } \\
\text { regular }(\%)\end{array}$ & 7 & 0 & 7,71 & 1,25 & 6 & 10 \\
\hline 2 & $\begin{array}{l}\text { Índice de Recuperação de Materiais Recicláveis - } \\
\text { IRMR (\%) }\end{array}$ & 7 & 0 & 7,86 & 1,57 & 6 & 10 \\
\hline 24 & Receita apurada em vendas (R\$/ mês) & 7 & 0 & 7,86 & 1,95 & 5 & 10 \\
\hline \multicolumn{8}{|c|}{ Muita Importância } \\
\hline 8 & $\begin{array}{l}\text { Preço médio de comercialização do mix de material } \\
\text { reciclável }(\mathrm{R} \$ / \mathrm{t})\end{array}$ & 7 & 0 & 8,00 & 0,58 & 7 & 9 \\
\hline 9 & Freqüência média de coletas $\left(\mathrm{n}^{\circ}\right.$ de coletas/ semana) & 7 & 0 & 8,00 & 1,15 & 7 & 10 \\
\hline 15 & $\begin{array}{|lll|}\begin{array}{l}\text { Percentual mensal } \\
\text { conformidades }(\%)\end{array} & \text { de } & \text { reclamações/não } \\
\end{array}$ & 7 & 0 & 8,29 & 1,38 & 6 & 10 \\
\hline 16 & $\begin{array}{l}\text { Percentual de resíduos orgânicos no lixo da coleta } \\
\text { seletiva }(\%)\end{array}$ & 7 & 0 & 8,29 & 1,38 & 7 & 10 \\
\hline 6 & Quantidade de PEVs instalados (un) & 7 & 0 & 8,43 & 1,62 & 6 & 10 \\
\hline 10 & Produção média de recicláveis por PEV (t/PEV) & 7 & 0 & 8,43 & 1,62 & 6 & 10 \\
\hline 19 & Custo de triagem $(\mathrm{R} \$ / \mathrm{t})$ & 7 & 0 & 8,57 & 1,27 & 7 & 10 \\
\hline 23 & Custo total da coleta seletiva $(\mathrm{R} \$ / \mathrm{t})$ & 7 & 0 & 8,71 & 1,25 & 7 & 10 \\
\hline 14 & $\begin{array}{l}\text { Custo mensal de Operação da Coleta e Transporte } \\
(\mathrm{R} \$ / \mathrm{t})\end{array}$ & 7 & 0 & 8,86 & 1,07 & 8 & 10 \\
\hline 20 & $\begin{array}{l}\text { Quantidade de itens de materiais recicláveis } \\
\text { comercializados (un) }\end{array}$ & 7 & 0 & 9,00 & 0,82 & 8 & 10 \\
\hline 18 & Quantidade mensal coletada seletivamente (t/mês) & 7 & 0 & 9,14 & 1,07 & 8 & 10 \\
\hline
\end{tabular}

* notas variando de

1 a 3 - pouca importância; $\quad 4$ a 7 - média importância e $\quad 8$ a 10 - muita importância. 


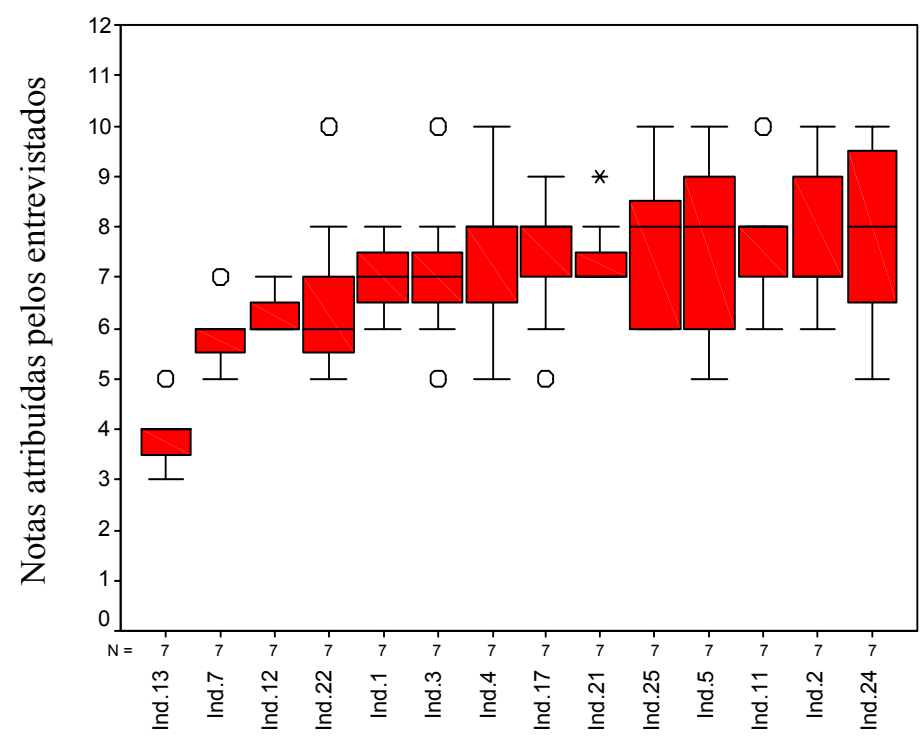

Gráfico 23 - Box Plot dos indicadores de média importância para o critério de avaliação REPRESENTATIVIDADE.

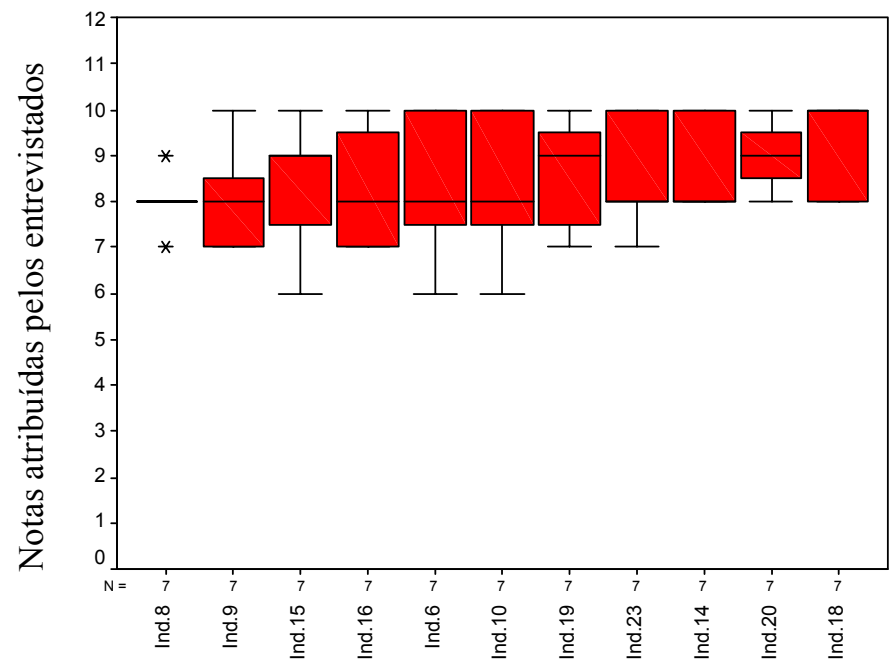

Gráfico 24 - Box Plot dos indicadores de muita importância para o critério de avaliação REPRESENTATIVIDADE. 


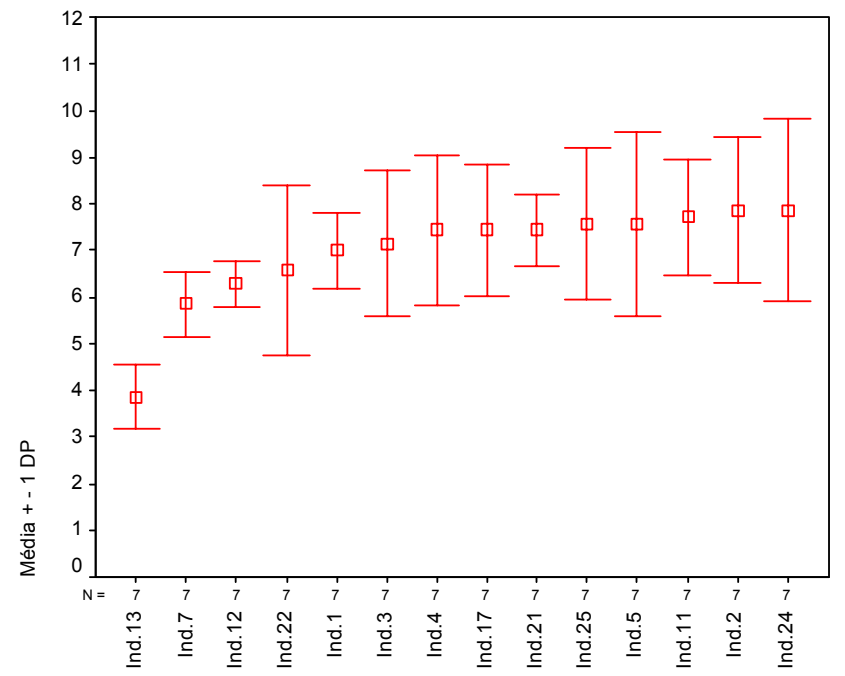

Gráfico 25 - Erro Bar dos indicadores de média importância para o critério de avaliação REPRESENTATIVIDADE.

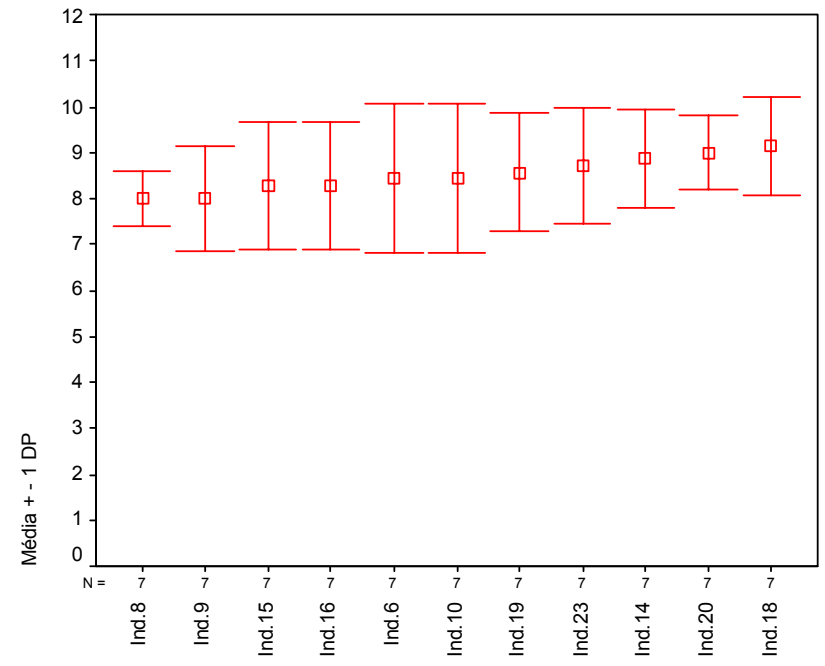

Gráfico 26 - Erro Bar dos indicadores de muita importância para o critério de avaliação REPRESENTATIVIDADE.

Para atribuir notas, segundo o critério REPRESENTATIVIDADE, foi solicitado aos entrevistados que considerassem a cobertura alcançada pelo indicador em relação a Programas de Coleta Seletiva. 
Tem-se na tabela 7 que a avaliação média dos indicadores varia entre os graus de média importância (4 a 7) a muita importância ( 8 a 10). Observa-se que o indicador percentual de rotatividade de catadores autônomos (\%), Var 13, continua apresentando menor avaliação média $(3,86)$ e o indicador Quantidade mensal coletada seletivamente ( $\mathrm{t} /$ mês), var 18 , maior avaliação média $(9,14)$. O indicador Densidade de coleta $(\mathrm{t} / \mathrm{h})$, apresenta menor variação em torno da média $(0,49)$ e o indicador de eficiência da Coleta Seletiva $(\mathrm{t} / \mathrm{km} / \mathrm{h})$ maior variação em torno da média $(1,99)$, em relação aos demais. Os demais indicadores apresentam desvio padrão entre 0,58 e 1,95 .

Apresenta-se na tabela 8 e nos gráficos 27, 28, 29 e 30 os resultados da avaliação dos indicadores feita pelos entrevistados, para o critério de avaliação OPORTUNIDADE, agrupados segundo grau de importância.

O critério oportunidade refere-se à simplicidade, a facilidade de obtenção e custo compatível. 
Tabela 8 - Resultados das avaliações dos indicadores feitas pelos entrevistados agrupados para o critério de avaliação OPORTUNIDADE, segundo grau de importância atribuída

\begin{tabular}{|c|c|c|c|c|c|c|c|}
\hline Var & INDICADOR & $\begin{array}{c}\mathbf{N} \\
\text { Válido }\end{array}$ & $\begin{array}{l}\text { Não Sabe/ } \\
\text { Não } \\
\text { Respondeu }\end{array}$ & Média & $\begin{array}{l}\text { Desvio } \\
\text { Padrão }\end{array}$ & $\begin{array}{c}\text { V. } \\
\text { Min. }\end{array}$ & $\begin{array}{l}\text { V. } \\
\text { Máx. }\end{array}$ \\
\hline \multicolumn{8}{|c|}{ Média Importância } \\
\hline 13 & $\begin{array}{l}\text { Percentual de rotatividade de catadores autônomos } \\
(\%)\end{array}$ & 7 & 0 & 4,29 & 0,76 & 3 & 5 \\
\hline 7 & $\begin{array}{l}\text { Quantidade mensal de catadores autônomos } \\
\text { envolvidos na organização (catadores/mês) }\end{array}$ & 7 & 0 & 5,86 & 0,90 & 5 & 7 \\
\hline 22 & $\begin{array}{l}\text { Eficiência de mão-de-obra de triagem } \\
\text { (t/trabalhador/hora) }\end{array}$ & 7 & 0 & 5,86 & 1,46 & 5 & 8 \\
\hline 11 & $\begin{array}{l}\text { Percentual de resíduos recicláveis no lixo da coleta } \\
\text { regular }(\%)\end{array}$ & 7 & 0 & 7,14 & 1,35 & 5 & 9 \\
\hline 16 & $\begin{array}{l}\text { Percentual de resíduos orgânicos no lixo da coleta } \\
\text { seletiva }(\%)\end{array}$ & 7 & 0 & 7,14 & 1,35 & 5 & 9 \\
\hline 17 & Índice mensal de vandalismo PEVs (\%) & 7 & 0 & 7,29 & 1,70 & 5 & 10 \\
\hline 21 & $\begin{array}{l}\text { Renda média mensal por catador autônomo } \\
\text { (R\$/catador/mês) }\end{array}$ & 7 & 0 & 7,43 & 0,79 & 6 & 8 \\
\hline 4 & $\begin{array}{l}\text { Investimento per capita anual no programa (R\$/ } \\
\text { hab/ano) }\end{array}$ & 7 & 0 & 7,43 & 1,72 & 5 & 10 \\
\hline 3 & Despesa com marketing e educação (R $\$$ /hab/ano) ( & 7 & 0 & 7,57 & 1,72 & 6 & 10 \\
\hline 2 & $\begin{array}{l}\text { Índice de Recuperação de Materiais Recicláveis - } \\
\text { IRMR (\%) }\end{array}$ & 7 & 0 & 7,71 & 1,89 & 5 & 10 \\
\hline 10 & Produção média de recicláveis por PEV (t/PEV) & 7 & 0 & 7,71 & 1,70 & 5 & 10 \\
\hline 12 & Densidade de Coleta $(\mathrm{t} / \mathrm{h})$ & 7 & 0 & 7,71 & 0,76 & 7 & 9 \\
\hline 25 & Eficiência da coleta seletiva $(\mathrm{t} / \mathrm{km} / \mathrm{h})$ & 7 & 0 & 7,71 & 1,50 & 6 & 10 \\
\hline \multicolumn{8}{|c|}{ Muito Importante } \\
\hline 1 & Cobertura do atendimento (hab) & 7 & 0 & 8,00 & 1,53 & 6 & 10 \\
\hline 5 & Relação Receita/Despesa & 7 & 0 & 8,14 & 1,68 & 6 & 10 \\
\hline 18 & Quantidade mensal coletada seletivamente (t/mês) & 7 & 0 & 8,14 & 1,21 & 7 & 10 \\
\hline 24 & Receita apurada em vendas (R\$/ mês) & 7 & 0 & 8,43 & 1,81 & 6 & 10 \\
\hline 6 & Quantidade de PEVs instalados (un) & 7 & 0 & 8,57 & 1,81 & 6 & 10 \\
\hline 15 & \begin{tabular}{|l}
$\begin{array}{l}\text { Percentual mensal de } \\
\text { conformidades }(\%)\end{array}$ \\
\end{tabular} & 7 & 0 & 8,57 & 1,40 & 7 & 10 \\
\hline 8 & $\begin{array}{l}\text { Preço médio de comercialização do mix de material } \\
\text { reciclável }(\mathrm{R} \$ / \mathrm{t})\end{array}$ & 7 & 0 & 8,71 & 0,49 & 8 & 9 \\
\hline 9 & Freqüência média de coletas ( $n^{\circ}$ de coletas/ semana) & 7 & 0 & 8,71 & 1,11 & 7 & 10 \\
\hline 14 & $\begin{array}{l}\text { Custo mensal de operação da coleta e transporte } \\
(\mathrm{R} \$ / \mathrm{t})\end{array}$ & 7 & 0 & 8,71 & 1,50 & 6 & 10 \\
\hline 19 & Custo de triagem $(\mathrm{R} \$ / \mathrm{t})$ & 7 & 0 & 8,71 & 0,76 & 8 & 10 \\
\hline 20 & $\begin{array}{l}\text { Quantidade de itens de materiais recicláveis } \\
\text { comercializados (un) }\end{array}$ & 7 & 0 & 8,86 & 0,69 & 8 & 10 \\
\hline 23 & Custo total da coleta seletiva $(\mathrm{R} \$ / \mathrm{t})$ & 7 & 0 & 8,86 & 1,07 & 7 & 10 \\
\hline
\end{tabular}

* notas variando de

1 a 3 - pouca importância; 


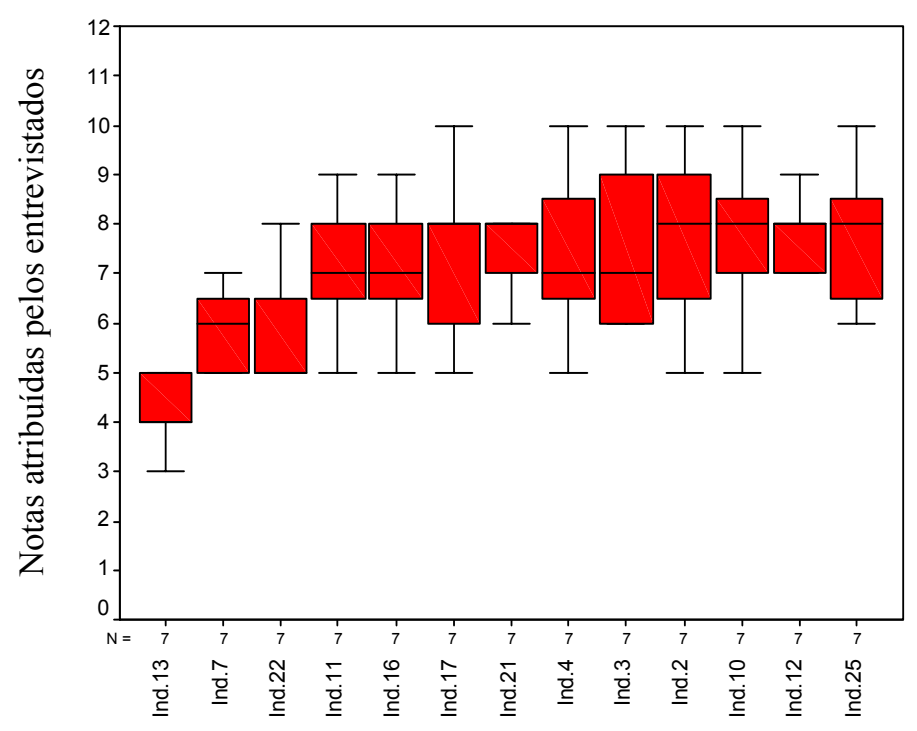

Gráfico 27 - Box Plot dos indicadores de média importância para o critério de avaliação OPORTUNIDADE.

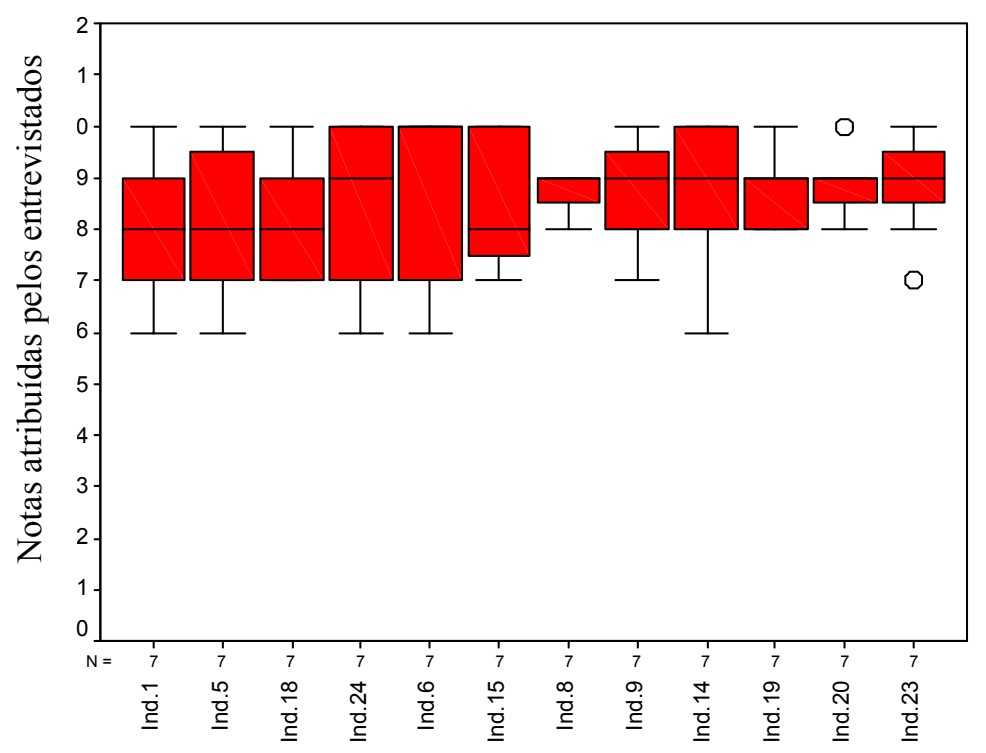

Gráfico 28 - Box Plot dos indicadores de muita importância para o critério de avaliação OPORTUNIDADE. 


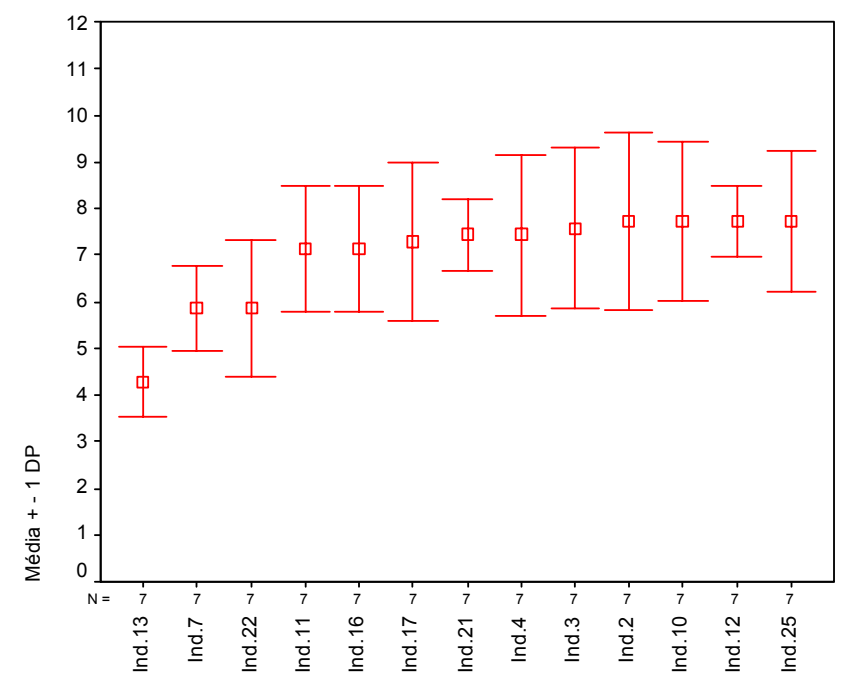

Gráfico 29 - Erro Bar dos indicadores de média importância para o critério de avaliação OPORTUNIDADE.

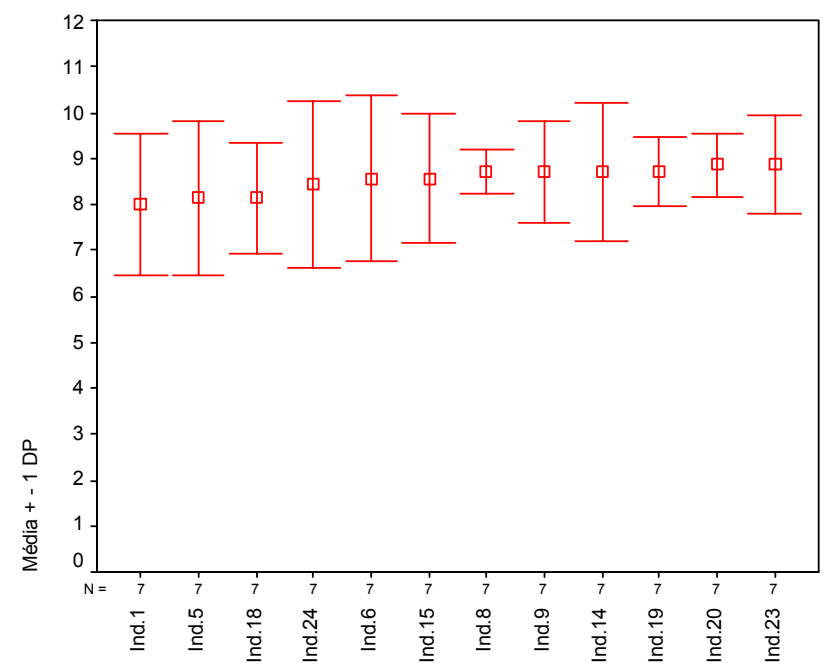

Gráfico 30 - Erro Bar dos indicadores de muita importância para o critério de avaliação OPORTUNIDADE.

Segundo a tabela 8 a avaliação média dos indicadores varia entre os graus de média importância (notas entre 4 a 7) e muita importância (notas entre 8 a 10), tendo o indicador percentual de rotatividade de catadores autônomos, Var 13, recebido a menor avaliação média $(8,86)$ e o indicador custo total da coleta seletiva, Var23, a maior avaliação $(8,86)$. O indicador preço médio de comercialização do mix de 
material reciclável $(\mathrm{R} \$ / \mathrm{t})$, Var 8 , apresentou menor variação em torno da média $(0,49)$, em relação aos demais, e o indicador Índice de Recuperação de Materiais Recicláveis - IRMR (\%), Var 2, maior variação $(1,89)$. Tendo os demais indicadores, apresentado desvio padrão variando entre 0,69 e 1,81.

Na tabela 9 tem-se apresentado a média geral dos resultados da avaliação dos indicadores feita pelos entrevistados, agrupados para diversos critérios de avaliação utilizados, segundo grau de importância atribuída.

apresentou a menor avaliação média geral $(4,04)$ e o indicador Quantidade de itens de materiais recicláveis comercializados (un), Var 20, a maior avaliação média geral $(9,04)$.

Verifica-se, a seguir, que a Var 13 também apresentou menor avaliação média quando avaliada para cada um dos critérios: VALIDADE, CONFIABILIDADE, REPRESENTATIVIDADE e OPORTUNIDADE, o que denota haver consenso do grupo de profissionais entrevistados quanto à avaliação desta variável.

Em termos gerais, como resultado da aplicação da técnica Delphi, 13 indicadores foram considerados como muito importantes, quando avaliados pelos critérios de qualidade adotados. Dentre estes, 4 também foram considerados muito importantes pela Análise Descritiva. Os aspectos de custo e renda aparecem em 5, dentre os indicadores de muita importância, através das variáveis 8, 14, 19, 23 e 24 .

A escala da coleta seletiva está representada pela variável quantidade mensal coletada seletivamente (t/mês), Var 18, enquanto que a participação na coleta seletiva está, indiretamente, contemplada pelas variáveis Índice de recuperação de materiais recicláveis - IRMR (\%), Var 2, e percentual de resíduos orgânicos no lixo da coleta seletiva (\%), Var 16.

As variáveis Percentual mensal de reclamações/não conformidades (\%), Var 15, Freqüência média de coletas ( $n^{\circ}$ de coletas/semana), Var 9, e Quantidade de itens de materias recicláveis comercializados (un), Var 20, representaram os aspectos de operação da coleta seletiva, incluindo a qualidade (Var 15).

Dentre os indicadores de muita importância estão 2 variáveis relativas à coleta seletiva por postos de entrega voluntária: quantidade de PEVS instalados (un), Var 6, e produção média de recicláveis por PEV's (t/PEV), Var 10. 
O aspecto de mobilização da comunidade (Var 3) não foi contemplado nos resultados da técnica Delphi.

Tabela 9 - Média geral dos resultados da avaliação dos indicadores feita pelos entrevistados, agrupados para diversos critérios de avaliação utilizados, segundo grau de importância atribuída.

\begin{tabular}{|c|c|c|c|c|c|c|}
\hline Var & INDICADOR & Geral & $\begin{array}{l}\text { Vali- } \\
\text { dade }\end{array}$ & $\begin{array}{l}\text { Confia- } \\
\text { bilidade }\end{array}$ & $\begin{array}{l}\text { Represen- } \\
\text { tatividade }\end{array}$ & $\begin{array}{l}\text { Opor- } \\
\text { tunidade }\end{array}$ \\
\hline \multicolumn{7}{|c|}{ Média Importância * } \\
\hline 13 & Percentual de rotatividade de catadores autônomos $(\%)$ & 4,04 & 4,00 & 4,00 & 3,86 & 4,29 \\
\hline 7 & $\begin{array}{l}\text { Quantidade mensal de catadores autônomos envolvidos na } \\
\text { organização (catadores/mês) }\end{array}$ & 6,47 & 6,71 & 7,43 & 5,86 & 5,86 \\
\hline 22 & Eficiência de mão-de-obra de triagem (t/trabalhador/hora) & 6,47 & 6,86 & 6,57 & 6,57 & 5,86 \\
\hline 12 & Densidade de coleta $(\mathrm{t} / \mathrm{h})$ & 7,18 & 6,14 & 8,57 & 6,29 & 7,71 \\
\hline 17 & Índice mensal de vandalismo PEVs (\%) & 7,54 & 7,43 & 8,00 & 7,43 & 7,29 \\
\hline 21 & $\begin{array}{l}\text { Renda média mensal por catador autônomo } \\
\text { (R\$/catador/mês) }\end{array}$ & 7,57 & 7,71 & 7,71 & 7,43 & 7,43 \\
\hline 3 & Despesa com marketing e educação (R\$/hab/ano) & 7,64 & 8,14 & 7,71 & 7,14 & 7,57 \\
\hline 1 & Cobertura do atendimento (hab) & 7,68 & 8,43 & 7,29 & 7,00 & 8,00 \\
\hline 11 & $\begin{array}{l}\text { Percentual de resíduos recicláveis no lixo da coleta regular } \\
(\%)\end{array}$ & 7,71 & 8,00 & 8,00 & 7,71 & 7,14 \\
\hline 5 & Relação Receita/Despesa & 7,82 & 7,86 & 7,71 & 7,57 & 8,14 \\
\hline 4 & Investimento per capita anual no programa (R\$/ hab/ano) & 7,82 & 8,00 & 8,43 & 7,43 & 7,43 \\
\hline 25 & Eficiência da coleta seletiva $(\mathrm{t} / \mathrm{km} / \mathrm{h})$ & 7,97 & 8,29 & 8,29 & 7,57 & 7,71 \\
\hline \multicolumn{7}{|c|}{ Muito Importante * } \\
\hline 2 & $\begin{array}{l}\text { IRMR - Índice de Recuperação de Materiais Recicláveis } \\
(\%)\end{array}$ & 8,18 & 8,57 & 8,57 & 7,86 & 7,71 \\
\hline 16 & $\begin{array}{l}\text { Percentual de resíduos orgânicos no lixo da coleta seletiva } \\
(\%)\end{array}$ & 8,18 & 8,71 & 8,57 & 8,29 & 7,14 \\
\hline 24 & Receita apurada em vendas (R\$/ mês) & 8,18 & 8,29 & 8,14 & 7,86 & 8,43 \\
\hline 10 & Produção média de recicláveis por PEV (t/PEV) & 8,39 & 9,00 & 8,43 & 8,43 & 7,71 \\
\hline 15 & Percentual mensal de reclamações/não conformidades (\%) & 8,43 & 8,43 & 8,43 & 8,29 & 8,57 \\
\hline 8 & $\begin{array}{l}\text { Preço médio de comercialização do mix de material } \\
\text { reciclável }(\mathrm{R} \$ / \mathrm{t})\end{array}$ & 8,50 & 8,14 & 9,14 & 8,00 & 8,71 \\
\hline 9 & Freqüência média de coletas ( ${ }^{\circ}$ de coletas/ semana) & 8,50 & 8,14 & 9,14 & 8,00 & 8,71 \\
\hline 19 & Custo de triagem $(\mathrm{R} \$ / \mathrm{t})$ & 8,50 & 8,43 & 8,29 & 8,57 & 8,71 \\
\hline 6 & Quantidade de PEVs instalados (un) & 8,61 & 8,71 & 8,71 & 8,43 & 8,57 \\
\hline 14 & Custo mensal de operação da coleta e transporte $(\mathrm{R} \$ / \mathrm{t})$ & 8,72 & 8,43 & 8,86 & 8,86 & 8,71 \\
\hline 18 & Quantidade mensal coletada seletivamente (t/mês) & 8,79 & 9,00 & 8,86 & 9,14 & 8,14 \\
\hline 23 & Custo total da coleta seletiva $(\mathrm{R} \$ / \mathrm{t})$ & 8,89 & 9,14 & 8,86 & 8,71 & 8,86 \\
\hline 20 & $\begin{array}{l}\text { Quantidade de itens de materiais recicláveis } \\
\text { comercializados (un) }\end{array}$ & 9,04 & 9,14 & 9,14 & 9,00 & 8,86 \\
\hline
\end{tabular}

* notas variando de

1 a 3 - pouca importância; $\quad 4$ a 7 - média importância e $\quad 8$ a 10 - muita importância. 
Na tabela 9 observa-se que, de acordo com a média geral por grau de importância, o indicador percentual de rotatividade de catadores autônomos (\%), Var 13,

\subsubsection{Definição do Grupo de Indicadores de Coleta Seletiva}

$\mathrm{Na}$ análise final, para facilitar a análise comparativa dos resultados da aplicação dos diferentes métodos estatísticos, aos 25 indicadores, inicialmente identificados, os mesmos foram relacionados no Quadro 10, segundo a ordem crescente do número de referência estabelecido para que cada indicador fosse tratado estatisticamente como variável.

Para facilitar a visualização do grupo de indicadores de referência a ser instituído, foram destacados, em negrito, os indicadores avaliados como muito importante pelos critérios de grau de importância na Análise Descritiva e também na Técnica Delphi. Em seguida, esses indicadores foram relacionados aos fatores identificados na Análise Multivariada Fatorial (Quadro 12). Ao final, 4 indicadores, destacados em negrito no Quadro 10, foram considerados como muito importante pela Análise Descritiva e pela Técnica Delphi e passam a integrar o grupo de indicadores de referência de coleta seletiva, objeto de pesquisa da presente tese.

Esses 4 (quatro) indicadores representam os aspectos de escala, custo e participação destacados na Análise Multivariada Fatorial, não contemplando o aspecto operacional da coleta seletiva.

Para compor o grupo de indicadores de referência ora estabelecido, destacam-se ainda as variáveis: cobertura de atendimento, Var 1, que recebeu a maior avaliação média na Análise Descritiva, e a quantidade de itens de materiais recicláveis comercializados, Var 20, que recebeu maior avaliação média na Técnica Delphi. 
Quadro 10 - Indicadores avaliados, como muito importante, na Análise Descritiva e na Técnica Delphi, relacionados aos fatores identificados na Análise Multivariada Fatorial.

\begin{tabular}{|c|c|c|c|c|}
\hline \multirow[b]{2}{*}{ Var } & \multirow[b]{2}{*}{ Indicador } & \multicolumn{3}{|c|}{ Resultado } \\
\hline & & $\begin{array}{c}\text { Análise } \\
\text { Multivariada } \\
\text { Fatorial } \\
\end{array}$ & $\begin{array}{c}\text { Análise } \\
\text { Descritiva }\end{array}$ & Técnica Delphi \\
\hline 1 & Cobertura de atendimento & $\begin{array}{l}\text { Fator } 2 \\
\text { Escala }\end{array}$ & $\begin{array}{c}\text { muito } \\
\text { importante }\end{array}$ & $\begin{array}{c}\text { média } \\
\text { importância }\end{array}$ \\
\hline 2 & $\begin{array}{l}\text { Índice de Recuperação de Materiais } \\
\text { para Reciclagem - IRMR }\end{array}$ & $\begin{array}{c}\text { Fator } 1 \\
\text { Participacão } \\
\end{array}$ & $\begin{array}{c}\text { muito } \\
\text { importante }\end{array}$ & $\begin{array}{c}\text { muito } \\
\text { importante }\end{array}$ \\
\hline 8 & $\begin{array}{l}\text { Preço médio de comercialização do } \\
\text { "mix" de material reciclável }\end{array}$ & $\begin{array}{c}\text { Fator } 7 \\
\text { sem interpretação }\end{array}$ & $\begin{array}{c}\text { média } \\
\text { importância }\end{array}$ & $\begin{array}{c}\text { muito } \\
\text { importante }\end{array}$ \\
\hline 9 & Freqüência média de coletas & $\begin{array}{c}\text { Fator } 6 \\
\text { Coleta Seletiva } \\
\text { PEV`s }\end{array}$ & $\begin{array}{c}\text { média } \\
\text { importância }\end{array}$ & $\begin{array}{c}\text { muito } \\
\text { importante }\end{array}$ \\
\hline 14 & $\begin{array}{l}\text { Custo mensal de operação de coleta e } \\
\text { transporte }\end{array}$ & $\begin{array}{c}\text { Fator } 3 \\
\text { Custo }\end{array}$ & $\begin{array}{c}\text { média } \\
\text { importância }\end{array}$ & $\begin{array}{c}\text { muito } \\
\text { importante }\end{array}$ \\
\hline 15 & $\begin{array}{l}\text { Percentual mensal de reclamações e } \\
\text { não conformidades }\end{array}$ & $\begin{array}{c}\text { Fator } 3 \\
\text { sem interpretação }\end{array}$ & $\begin{array}{l}\text { média } \\
\text { importância }\end{array}$ & $\begin{array}{c}\text { muito } \\
\text { importante }\end{array}$ \\
\hline 16 & $\begin{array}{l}\text { Percentual de resíduos orgânicos no } \\
\text { lixo da coleta seletiva }\end{array}$ & $\begin{array}{c}\text { Fator } 1 \\
\text { Participação }\end{array}$ & $\begin{array}{c}\text { média } \\
\text { importância }\end{array}$ & $\begin{array}{l}\text { muito } \\
\text { importante }\end{array}$ \\
\hline 18 & $\begin{array}{|lll|}\text { Quantidade mensal coletada } \\
\text { Seletivamente }\end{array}$ & $\begin{array}{l}\text { Fator } 2 \\
\text { Escala }\end{array}$ & $\begin{array}{c}\text { muito } \\
\text { importante }\end{array}$ & $\begin{array}{c}\text { muito } \\
\text { importante }\end{array}$ \\
\hline 19 & Custo de triagem & $\begin{array}{c}\text { Fator } 3 \\
\text { Custo }\end{array}$ & $\begin{array}{c}\text { muito } \\
\text { importante }\end{array}$ & $\begin{array}{c}\text { Muito } \\
\text { importante }\end{array}$ \\
\hline 20 & $\begin{array}{l}\text { Quantidade de itens de materiais } \\
\text { recicláveis comercializados }\end{array}$ & $\begin{array}{c}\text { Fator } 4 \\
\text { Operacional }\end{array}$ & $\begin{array}{l}\text { média } \\
\text { importância }\end{array}$ & $\begin{array}{c}\text { muito } \\
\text { importante }\end{array}$ \\
\hline 21 & Renda média por catador autônomo & $\begin{array}{c}\text { Fator } 5 \\
\text { Trabalhadores } \\
\text { Autônomos } \\
\end{array}$ & $\begin{array}{c}\text { muito } \\
\text { importante }\end{array}$ & $\begin{array}{c}\text { média } \\
\text { importância }\end{array}$ \\
\hline 23 & Custo total da coleta seletiva & \begin{tabular}{|c|} 
Fator 4 \\
sem interpretação \\
\end{tabular} & $\begin{array}{c}\text { Muito } \\
\text { importante }\end{array}$ & $\begin{array}{c}\text { Muito } \\
\text { importante }\end{array}$ \\
\hline 24 & Receita apurada em vendas & $\begin{array}{c}\text { Fator } 3 \\
\text { Custo }\end{array}$ & $\begin{array}{c}\text { média } \\
\text { importância }\end{array}$ & $\begin{array}{c}\text { muito } \\
\text { importante }\end{array}$ \\
\hline 25 & Eficiência da coleta seletiva & $\begin{array}{c}\text { Fator } 3 \\
\text { Custo }\end{array}$ & $\begin{array}{c}\text { muito } \\
\text { importante }\end{array}$ & $\begin{array}{c}\text { média } \\
\text { importância }\end{array}$ \\
\hline
\end{tabular}

Estabeleceu-se assim, o grupo de 6 indicadores (Quadro 11) para o qual adotou-se a terminologia Indicadores de Referência da Coleta Seletiva. 
Quadro 11 - Indicadores de Referência da Coleta Seletiva.

1. Cobertura de atendimento do programa (hab)

2. Índice de Recuperação de Materiais Recicláveis - IRMR (\%)

3. Quantidade mensal coletada seletivamente (t/mês)

4. Custo de triagem (R\$/t)

5. Quantidade de itens de materiais recicláveis comercializados (un)

6. Custo total do programa $(\mathrm{R} \$ / \mathrm{t})$

Observa-se que, nos Indicadores de Referência da Coleta Seletiva ora obtidos, estão contemplados os aspectos de custo, escala, operacional e de participação da população conforme indicação da Análise Multivariada Fatorial.

A seguir, são apresentados e descritos os Indicadores de Referência de Coleta Seletiva estabelecidos na presente pesquisa.

\section{Indicadores de Referência da Coleta Seletiva}

\section{Cobertura de Atendimento do programa (hab)}

A cobertura de atendimento representa a escala, a amplitude do programa de coleta seletiva. É fundamental para balizar a análise comparativa de desempenho de distintos programas de coleta seletiva. Esse indicador também pode ser expresso em percentual.

Para possibilitar a aplicação deste indicador, quando expresso em percentual, na análise comparativa entre dois programas de coleta seletiva, é necessário explicitar o parâmetro de referência adotado para o cálculo e o seu valor.

O conhecimento de maiores detalhes do local onde está implantado o programa e da(s) modalidade(s) de coleta seletiva adotadas auxilia nesta análise.

A cobertura de atendimento não representa a população que participa da coleta seletiva e, sim, a que é atendida, a qual tem ao seu dispor o serviço de coleta, que é de utilização compulsória.

Trata-se de um indicador de fácil apuração, como por exemplo: 
- no caso de programas em bairros ou regiões, pelas modalidades porta a porta e organização de trabalhadores autônomos, pode-se lançar mão dos dados censitários mais recentes relativos à população residente no local;

- no caso de condomínos, a administração local deve possuir a informação sobre o número de moradores; e,

- no caso da coleta seletiva por PEV`s, tem-se a cobertura de atendimento do serviço restrita a uma região de influência que, necessariamente, não representa um bairro ou uma região censitária. Pode-se trabalhar então com os dados de densidade populacional e a área de influência do PEV para o cálculo da população atendida.

\section{IRMR - Índice de Recuperação de Materiais Recicláveis (\%)}

O IRMR é de grande interesse na avaliação dos resultados alcançados pelos programas, pois permite a análise comparativa do quanto se está recuperando em relação ao total de resíduos sólidos coletados, no âmbito do sistema em que a coleta seletiva está implantada.

Geralmente resulta em valores que, para o leigo, a população em geral, parecem baixos, pouco significativos, o que talvez explique uma certa confusão que exista na sua aplicação prática.

O IRMR tem sido aplicado de diversas formas pelos programas de coleta seletiva existentes no país, entretanto, no momento em que é divulgado, não tem sido acompanhado de informações complementares, que o defina adequadamente.

No caso dos municípios, algumas vezes, o IRMR é calculado em relação ao total de resíduos sólidos urbanos coletados em toda cidade e, outras vezes, especificamente em relação aos resíduos sólidos gerados pela parcela da população ou região atendida com a coleta seletiva. Assim sendo, os valores resultantes são bastante diferentes e possuem significados diversos.

Ocorrem, ainda, casos em que não se desconta a parcela de rejeitos gerados a partir da triagem dos recicláveis coletados, o que resulta em valores sobrestimados.

Em suma, o ideal é que o IRMR venha acompanhado de informação sobre os critérios adotados para seu cálculo. 


\section{Quantidade mensal coletada seletivamente (t/mês)}

É um indicador de fácil assimilação e entendimento que, entretanto, pressupõe a existência de algum controle de peso dos materiais recicláveis coletados.

No caso de programas modestos e ou que utilizam trabalhadores autônomos da reciclagem, normalmente, a apuração do peso somente ocorre no momento da venda dos materiais o que pode acarretar alguns desvios no cálculo deste indicador, como:

- falta de controle do peso do rejeito gerado na triagem, cujo valor deveria ser acrescentado ao montante de recicláveis triados e comercializados no mesmo período de tempo; e,

- periodicidade diferenciada para comercialização de materiais coletados em menor escala e ou com mercado restrito.

Para tais situações, pode-se adotar o critério de se controlar o fluxo mensal de materiais no programa de coleta seletiva, desde que explicitado no momento da divulgação dos dados.

O monitoramento da quantidade mensal coletada seletivamente pelo programa permite acompanhar, de perto, a sua evolução, as interferências de fatores externos, como sazonalidades na geração de resíduos sólidos, campanhas de divulgação, existência de outras coletas paralelas de material reciclável, como é o caso da ação de sucateiros, entre outros.

\section{Custo de triagem $(\mathrm{R} \$ / \mathrm{t})$}

A etapa de triagem é fundamental para o funcionamento do programa de coleta seletiva, interferindo na obtenção de mercado para comercialização dos materiais recicláveis recuperados.

A triagem pode ser realizada por processos que variam desde totalmente manuais a altamente mecanizados, dependendo da quantidade de material processado e da infraestrutura disponível.

Alguns municípios adotam a estratégia de realizar parceria com organização de trabalhadores autônomos, para realização da triagem dos resíduos recicláveis 
coletados, onde a administração pública assume algumas despesas e a receita da venda dos materiais é revertida para pagamento da mão-de-obra.

Para tal situação, ocorre que, algumas vezes, as informações necessárias para se apurar o real custo de triagem encontram-se dispersas, não existindo o seu registro de rotina.

Apesar de existir pouca tradição nos programas de coleta seletiva implantados por municípios quanto ao registro dessa informação, é importante conhecer e monitorar o custo de triagem, pois pode representar uma despesa significativa para a coleta seletiva, sendo indispensável, ainda, para compor o cálculo do custo total do programa de coleta seletiva.

A figura 34, a seguir, ilustra um processo manual de triagem, visitado no município de Florianópolis em 2002.

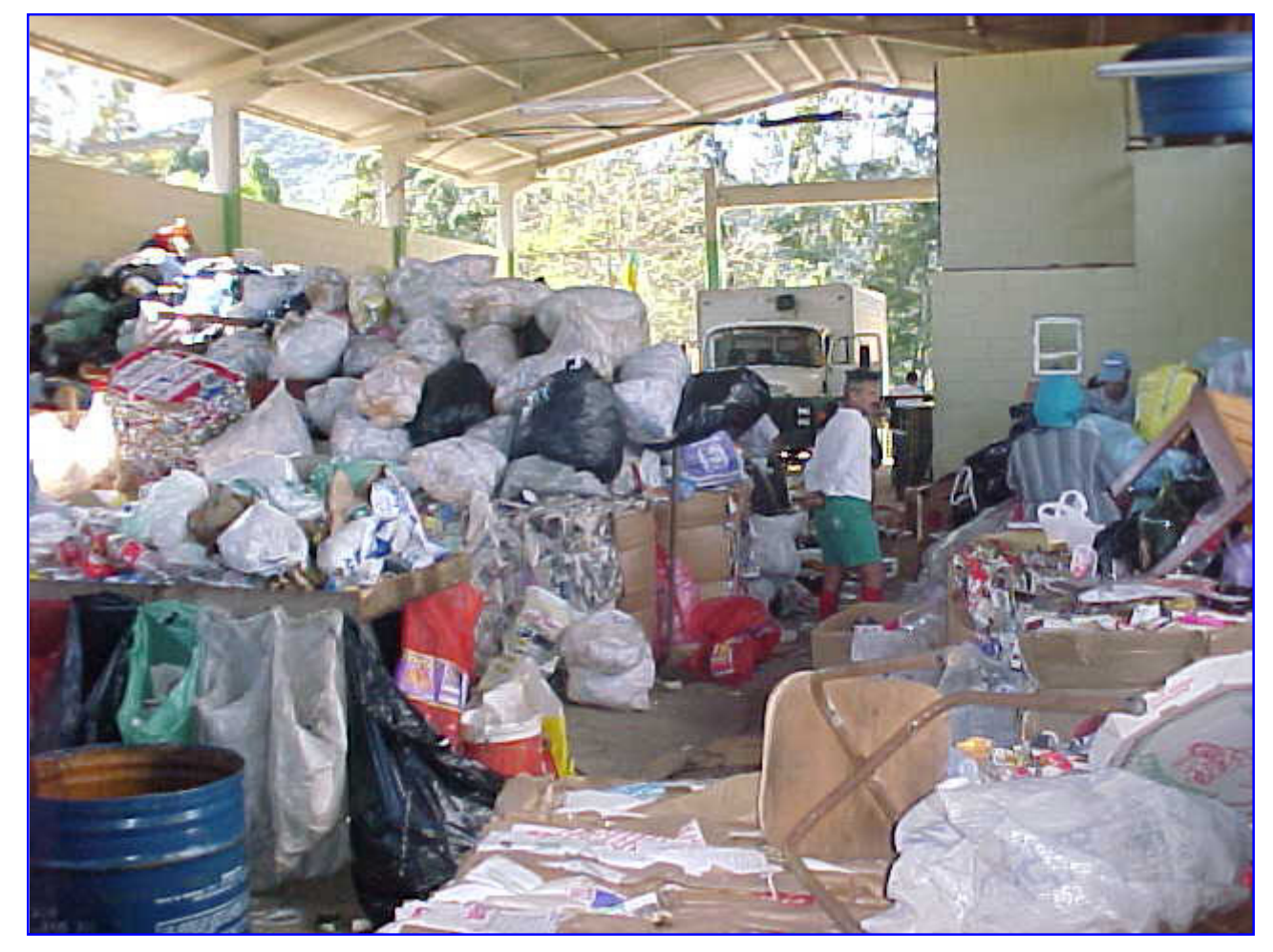

Figura 34 - Vista de unidade de triagem operada por organização de trabalhadores autônomos da reciclagem, Florianópolis, 2002. 


\section{Quantidade de itens de materiais recicláveis comercializados (un)}

O indicador quantidade de itens de materiais recicláveis comercializados está diretamente ligado à modalidade de coleta seletiva adotada, ao seu tamanho, sua estrutura de operação de coleta e de triagem e beneficiamento, incluindo área para estocagem de materiais recicláveis.

Possui, ainda, relação direta com o mercado de recicláveis do local onde está inserido o programa de coleta seletiva, que pode variar em função da quantidade de materiais recicláveis movimentados e das sazonalidades na geração de resíduos sólidos.

Trata-se de um valor de referência, característico de cada programa, que varia pouco ao longo do tempo. Denota a especialização do processo de triagem e beneficiamento. Os programas de coleta seletiva de maior escala e estrutura, geralmente desenvolvidos por governos municipais, trabalham com um número maior de itens de materiais recicláveis comercializados em relação aos programas de menor escala, como organização de trabalhadores autônomos da reciclagem, onde são priorizados os materiais de maior valor de mercado.

\section{Custo total do programa $(\mathrm{R} \$ / \mathrm{t})$}

Trata-se de um indicador que desperta grande interesse por parte de todos os que estão, direta e indiretamente, envolvidos com a coleta seletiva. Todos querem saber:

\section{Quanto custa ???}

Diversas metodologias de cálculo propostas são encontradas, desde a somatória das parcelas referentes às diversas despesas do programa, passando por uma simples operação aritmética de subtração entre despesas e receitas, até um cálculo que se considera custos evitados e economia de recursos naturais como proposto por CALDERONI (1998).

Para os Indicadores de Referência propostos, adotou-se a metodologia de cálculo onde são considerados custos evitados, mas, não propõe quantificar a economia de recursos naturais pela dificuldade prática apresentada.

$\mathrm{Na}$ prática, a melhor metodologia a ser adotada vai depender das características do programa de coleta seletiva e do sistema de limpeza pública existentes. Não há como quantificar economia de aterro sanitário se os resíduos são dispostos em lixão. 
Infelizmente, ainda, tem-se no Brasil municípios com coleta seletiva e disposição final de resíduos em lixão.

Propõe-se trabalhar o custo unitário $(\mathrm{R} \$ / \mathrm{t})$, que relaciona o custo total do programa com a quantidade de materiais recicláveis coletados, para permitir melhor aplicação do indicador na comparação entre programas de coleta seletiva.

Procedendo-se a uma análise geral dos Indicadores de Referência estabelecidos, temse que:

- possuem aplicação prática pela facilidade de entendimento e apuração;

- podem ser complementados com outros indicadores específicos, caso a caso, em função da modalidade de coleta seletiva adotada e da estrutura da entidade gestora do programa;

- medem variáveis relativas aos resultados dos programas de coleta seletiva avaliado; e,

- permitem avaliar o progresso dos programas de coleta seletiva implantados, em relação aos resultados desejados e estabelecer tendências futuras;

Cabe ressaltar que, para se obter resultados efetivos da aplicação dos indicadores é necessário o monitoramento contínuo do programa de coleta seletiva avaliado, bem como a obtenção de dados confiáveis. Por sua vez, os valores obtidos para os Indicadores de Referência devem ser analisados em conjunto, destacando-se os elos existentes entre os resultados apresentados, individualmente, pelos mesmos.

A partir dos resultados da Fase 1, partiu-se para o desenvolvimento da Fase 2, que refere-se à aplicação do grupo de indicadores de referência à série histórica de dados do município de Vitória.

\section{Fase 2 - Estudo de Caso - Aplicação dos Indicadores de Referência para o município de Vitória - ES}

No desenvolvimento do estudo de caso para o município de Vitória-ES, os Indicadores de Referência foram aplicados à série histórica de dados do município, para o período de janeiro de 2001 a maio de 2003, obtendo-se os resultados a seguir apresentados. 
Os indicadores foram aplicados individualmente para cada uma das modalidades de coleta seletiva utilizadas (PEVs, organização de trabalhadores autônomos da reciclagem e porta a porta) e, também, para os resultados globais do Programa de Coleta Seletiva de Vitória.

Para a modalidade organização de trabalhadores autônomos da reciclagem, adotou-se a terminologia ASCAMARE - Associação de Catadores de Materiais Recicláveis, que representa a entidade que atua no município. A partir dos resultados obtidos pelos indicadores associados às informações coletadas, durante o acompanhamento e registro da rotina da coleta seletiva, foram identificados os pontos críticos dos programas de coleta seletiva implantados.

Inicialmente, foram levantados dados referentes ao indicador cobertura de atendimento (hab) sendo os resultados obtidos apresentados no gráfico 31 .

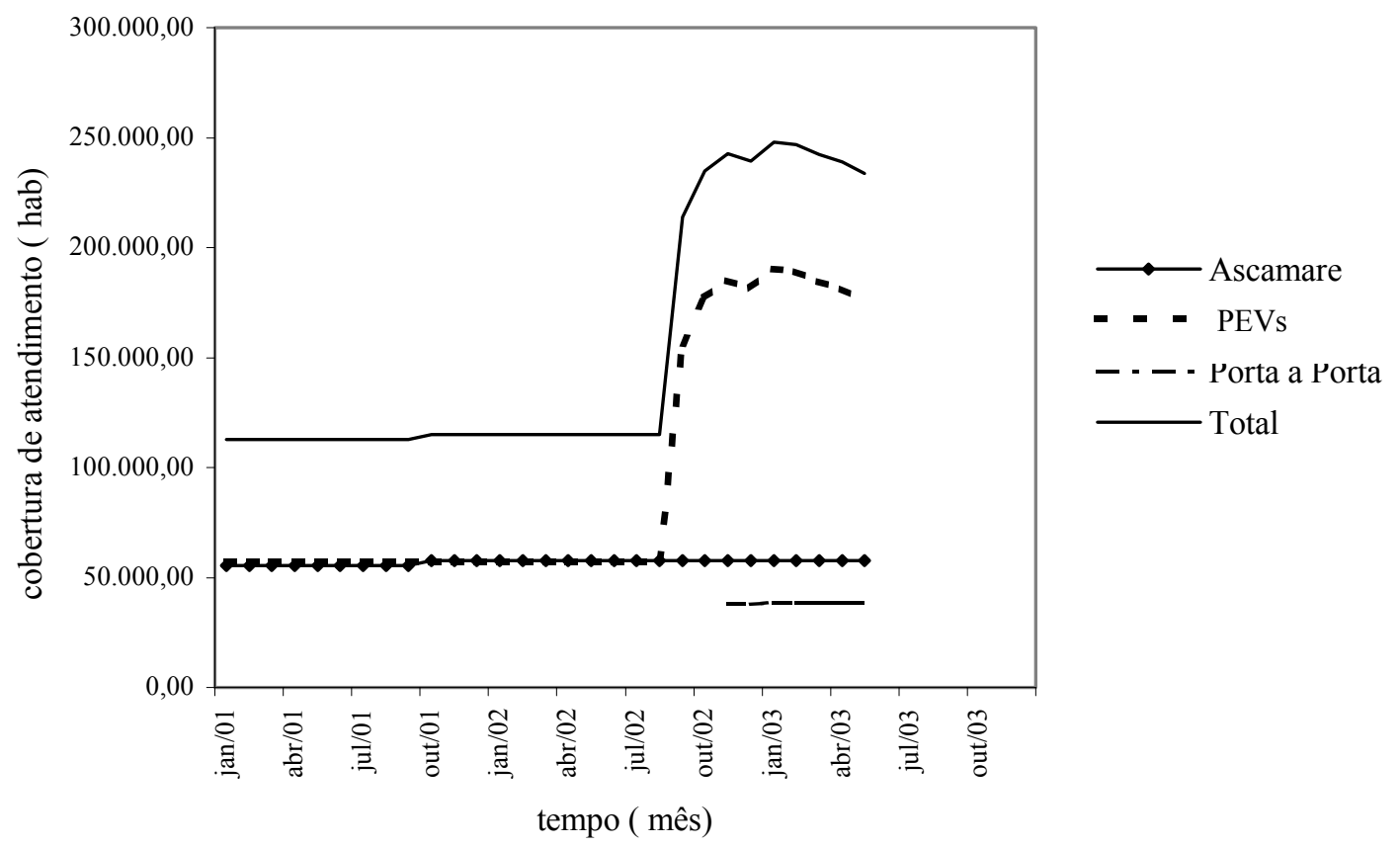

Gráfico 31 - Evolução da cobertura de atendimento (hab), segundo modalidade de coleta seletiva, período de janeiro/ 2003 a maio/ 2003. Vitória, 2003.

O indicador cobertura de atendimento (hab) varia em função da ampliação ou redução do serviço de coleta seletiva oferecido à população.

No caso de Vitória, a variação mais significativa do indicador cobertura de atendimento (hab) ocorreu na modalidade de coleta seletiva por meio de postos de 
entrega voluntária, a qual teve um grande incremento em 2002, a partir de investimentos feitos pela prefeitura para a ampliação e modernização do programa existente. Por sua vez, os dados de cobertura de atendimento da coleta seletiva porta a porta, somente passaram a existir a partir da sua implantação, em novembro de 2002.

A análise desse indicador torna-se mais consistente quando feita em conjunto com outros indicadores do grupo como a quantidade de materiais recicláveis coletados $(\mathrm{t})$ e o custo do programa ( $\mathrm{R} \$ / \mathrm{t})$, sempre se levando em conta as peculiaridades das diversas modalidades de coleta seletiva.

Para o indicador Índice de Recuperação de Materiais para Reciclagem (IRMR) os resultados são apresentados no gráfico 32 .

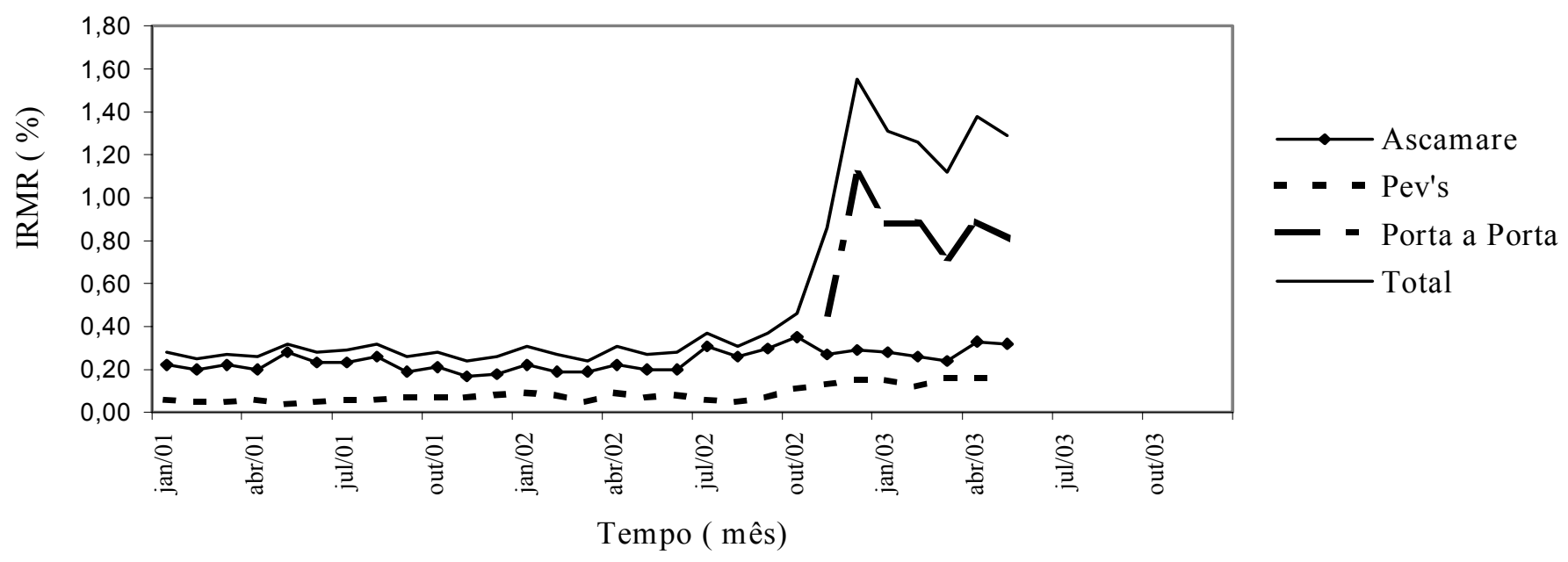

Gráfico 32 - Evolução do IRMR, segundo modalidade de coleta seletiva existentes no período de janeiro/ 2001 a maio/ 2003. Vitória, 2003. 
O IRMR (\%) reflete, indiretamente, a adesão da população ao programa de coleta seletiva e permite avaliar, ao longo do tempo, o seu desempenho quanto à recuperação de materiais recicláveis. Permite, ainda, a análise comparativa, individual e em conjunto, do desempenho das diversas modalidades de coleta seletiva.

Os valores obtidos para o IRMR, nas modalidades de coleta seletiva por meio de PEVs e ASCAMARE, tiveram pouca variação ao longo do tempo.

No caso dos PEVs é possível avaliar ainda os seguintes aspectos:

- no período de janeiro de 2001 a setembro de 2002, quando a quantidade de PEVs ficou inalterada e não foram realizadas novas ações de divulgação pela prefeitura, constatou-se a existência de um grupo populacional cativo que internalizou o hábito de participar da coleta seletiva; e,

- no período de outubro de 2002 a maio de 2003, quando a quantidade de PEVs foi quadruplicada, o IRMR teve pouca variação em relação ao seu desempenho anterior, reflexo da insuficiência nas ações de divulgação e mobilização da população.

Para a ASCAMARE, que teve o galpão de apoio ao trabalho dos catadores transferido para outro local, em outubro de 2001, apesar das mudanças de rotina e da fase de adaptação, o resultado do IRMR foi mantido com tendência de crescimento.

A coleta seletiva porta a porta teve a maior variação do IRMR, com pico no resultado obtido em dezembro de 2002, que pode ser avaliado como reflexo da ação intensiva de divulgação e mobilização, desenvolvida pela prefeitura até o dia 20 de dezembro de 2002.

Cabe ressaltar que com os resultados do IRMR obtidos, constata-se que a participação da população na coleta seletiva não cresce na mesma proporção dos investimentos feitos, sendo este crescimento mais lento no caso da modalidade por meio de PEVs, que exige maior esforço do cidadão para participar.

A existência de ações de divulgação e mobilização da população, quanto à adesão à coleta seletiva, reflete na participação de um número maior de indivíduos (grupo cativo e de participação eventual) que vai gradativamente acomodando-se quando cessa o estímulo (Hipótese 2). 
Para o indicador quantidade mensal coletada seletivamente ( $\mathrm{t} / \mathrm{mês})$ tem-se os resultados apresentados no gráfico 33.

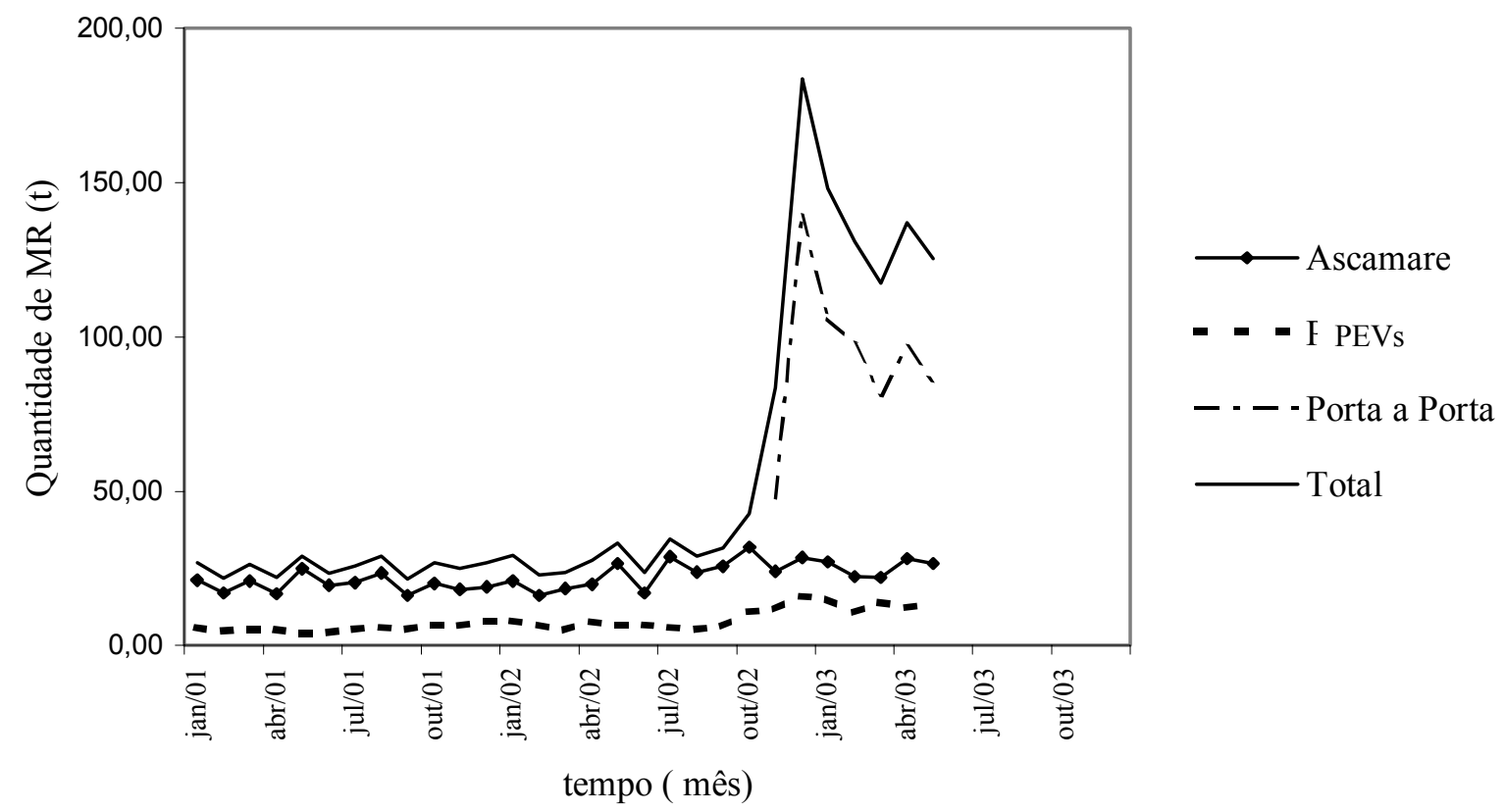

Gráfico 33 - Evolução da quantidade de materiais recicláveis (MR) coletados ( $\mathrm{t}$ ), segundo modalidade de coleta seletiva, no período de janeiro/ 2001 a maio/ 2003. Vitória, 2003.

Assumindo que a coleta seletiva recolhe efetivamente materiais recicláveis (MR), na análise comparativa da quantidade de MR coletado $(\mathrm{t})$, em relação à cobertura de atendimento (hab), para as mesmas modalidades de coleta seletiva existentes em Vitória, destaca-se a maior quantidade de MR coletados pela coleta seletiva porta a porta.

No caso de Vitória, a coleta seletiva porta a porta tem menor cobertura de atendimento populacional e é responsável pela maior parcela de MR coletado (t). Atribui-se tal fato à maior facilidade que essa modalidade oferece à população para participar, pois o veículo de coleta passa na porta das residências e estabelecimentos, associado à divulgação e ao fato da prefeitura ter adotado a regra de deixar de coletar o resíduo que não estiver adequadamente separado.

Por outro lado, a coleta seletiva por PEVs possui a maior cobertura de atendimento populacional e contribui com a menor parcela de MR coletado (t). 
A utilização dos PEVs demanda maior esforço do cidadão, que além de separar o resíduo, deve se deslocar até o local onde o mesmo está instalado. Observa-se que a parcela da população, que utiliza, rotineiramente, a coleta seletiva por postos de entrega voluntária é mais consciente e já internalizou o hábito de separar o resíduo, fazendo parte do grupo populacional cativo (Hipótese 2).

Em termos da qualidade dos materiais recicláveis coletados tem-se que a coleta seletiva porta a porta apresenta percentuais de rejeitos em torno de $30 \%$ e a coleta por meio de PEVs em torno de $10 \%$. O percentual de rejeitos representa a presença de matéria orgânica e outros materiais impróprios.

Cabe ressaltar que, no lançamento da etapa de ampliação do programa de coleta seletiva houve maior investimento em divulgação e mobilização da população para a coleta seletiva porta a porta em relação aos PEVs. A coleta seletiva por organização de catadores autônomos obteve um pequeno incremento na quantidade de MR coletado $(\mathrm{t})$.

Fatores externos, como a sazonalidade da produção de resíduos sólidos, desaceleração da economia do país e o aumento dos números de catadores de MR e de sucateiros na cidade também interferem na quantidade de MR (t) coletada pelos programas de coleta seletiva implantados.

Quanto aos fatores relacionados aos picos apresentados na curva da coleta seletiva porta a porta, relativa à parcela de MR coletado (t), tem-se a coleta paralela promovida pelos catadores como principal fator interveniente, conforme apresentado no item 6.1.5 que trata da experiência do município de Vitória.

Os resultados do indicador custo de triagem $(\mathrm{R} \$ / \mathrm{t})$ estão apresentados no gráfico 34 . 


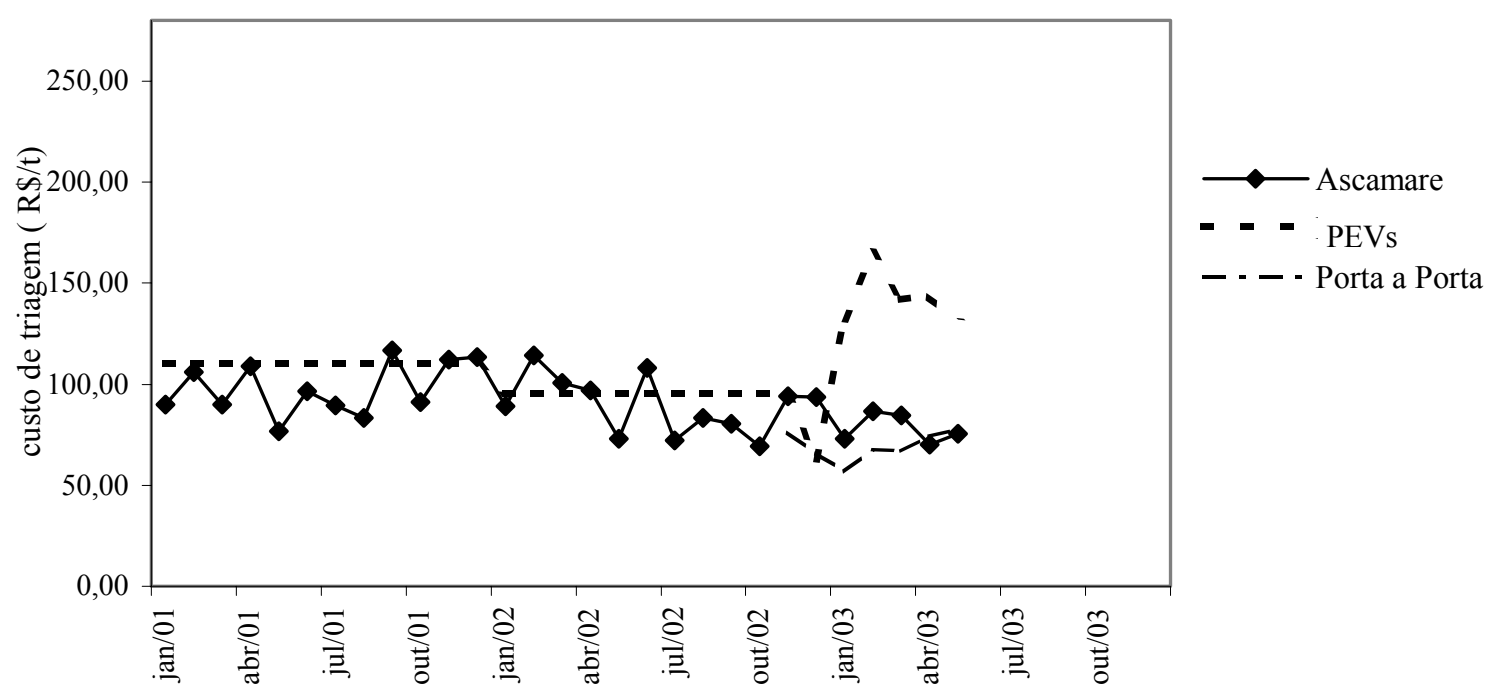

Gráfico 34 - Evolução do custo de triagem $(\mathrm{R} \$ / \mathrm{t})$, segundo modalidade de coleta seletiva, período de janeiro/ 2001 a maio/ 2003. Vitória, 2003.

Para as modalidades de coleta seletiva por PEVs e porta a porta, que são operadas pela prefeitura, os materiais recicláveis são triados na UTCV, onde também é feita a triagem de recicláveis presentes nos resíduos de coleta regular da cidade.

Devido à sua baixa qualidade e à insuficiência da estrutura operacional e de pessoal da UTCV, os recicláveis, recolhidos pela coleta seletiva porta a porta, são triados na mesma linha de produção que segrega os demais resíduos sólidos domiciliares coletados pela municipalidade. Por sua vez os materiais oriundos da coleta seletiva por PEVs são triados em separado, mediante processo totalmente manual.

Assim sendo, o custo unitário de triagem dos materiais recicláveis, obtidos na coleta seletiva porta a porta, foi obtido a partir do custo de produção da UTCV, em função do total de resíduos processados. Para a coleta seletiva por PEVs os custos foram apurados em separado, conforme critério apresentado no anexo 1.

Para avaliar o indicador que trata da evolução da quantidade de itens de materiais recicláveis comercializados (un), no período de tempo estudado, definiu-se por não elaborar um gráfico, já que esse indicador não apresenta variações significativas ao longo do tempo. 
A UTCV recupera, em média, $350 \mathrm{t}$ mensais de materiais recicláveis, incluindo a parcela da coleta seletiva, conseguindo assim mercado mais especializado para seus produtos. Em 2003, a UTCV realizava leilões periódicos e comercializava em média 33 itens diferentes de materiais recicláveis (Quadro 12).

Quadro 12 - Itens de materiais recicláveis comercializados pela UTCV.

\begin{tabular}{|ll} 
Metais & Plásticos \\
Alumínio mole & Polipropileno (PP) (água mineral) \\
Alumínio duro & Polietileno Alta Densidade (PEAD) \\
Metal & Poliestireno \\
Cobre limpo & PET \\
Cobre encapado & Polipropileno (diversos) \\
Antimônio & Sucata de cadeiras PP \\
Aço inox & Sucata plástica mista \\
Bateria & Plástico filme de Baixa Densidade (PEBD \\
Latinha de alumínio & filme) \\
Lata ferrosa & \\
Sucata mista ferrosa & Outros \\
Vidros & Madeira \\
Vidro colorido âmbar & Motor de geladeira \\
Vidro colorido (verde/azul) & Marmitex \\
Vidros peça & Chapas de radiografia \\
Cacos de vidro & \\
Papéis & \\
Arquivo & \\
Jornal & \\
Misto & \\
Papelão & \\
Embalagem Longavida & \\
\end{tabular}

Por sua vez, a ASCAMARE opera em menor escala, com foco nos materiais de maior valor de mercado. Comercializa seus materiais para sucateiros e aparistas e trabalha, em média, com 10 e 11 diferentes itens de materiais recicláveis, sendo os mesmos: papelão, papel misto, papel jornal, aparas brancas, papel escritório, PET, PEAD, PEBD, alumínio, metais (cobre, etc) e ferro. 
Finalizando o estudo de caso, têm-se para o indicador custo total do programa ( $R \$ / t)$ os resultados apresentados no gráfico 35 .

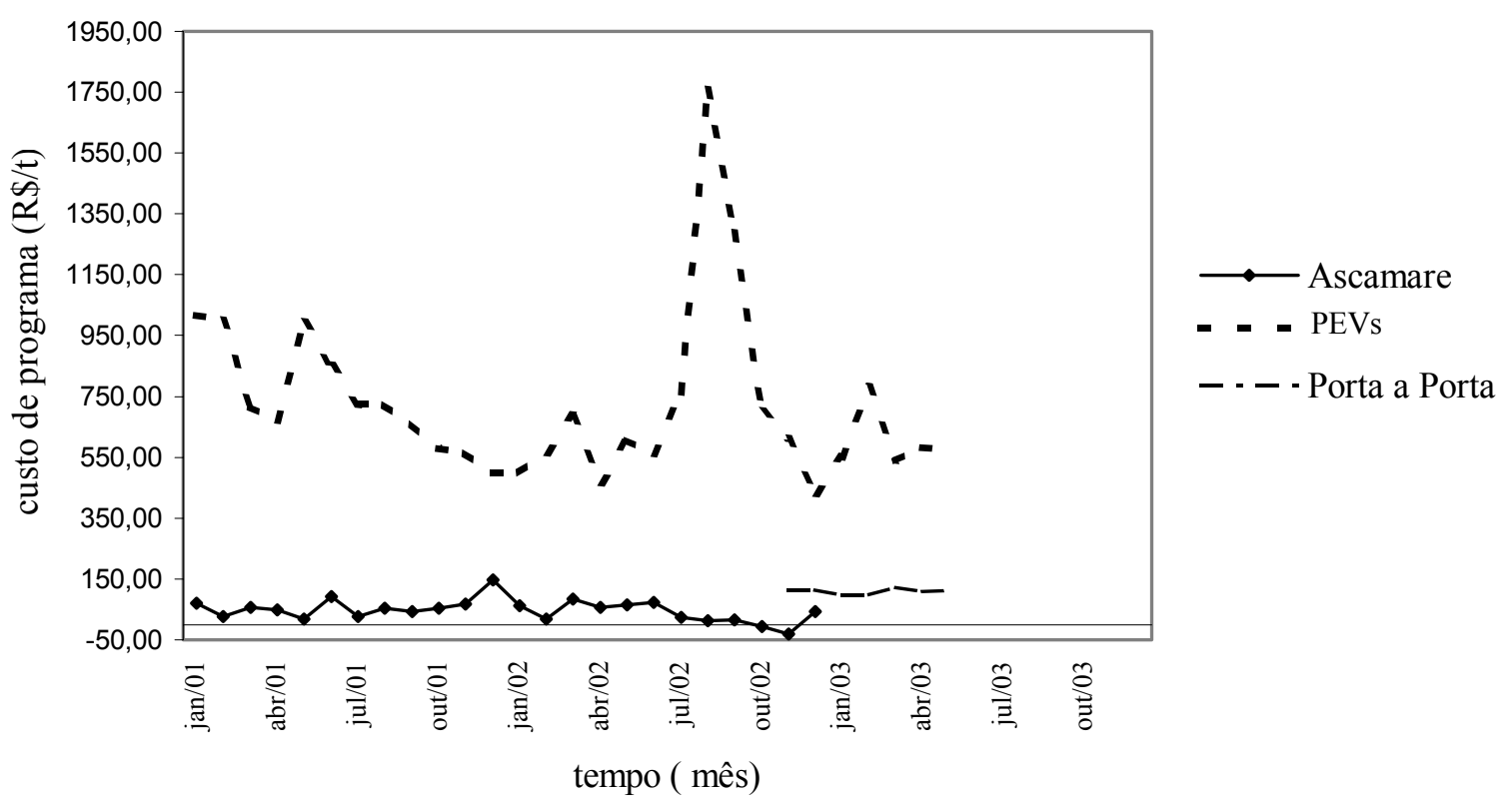

Gráfico 35 - Evolução do custo do programa (R\$/t), segundo modalidades de coleta seletiva, período de janeiro/ 2001 a maio/ 2003. Vitória, 2003.

Analisando-se a evolução do custo do programa de coleta seletiva de Vitória, por tonelada de materiais recicláveis coletados, para as diferentes modalidades existentes tem-se:

- a coleta seletiva por PEVs apresentou os maiores custos unitários o que reflete o seu baixo desempenho em termos da quantidade de materiais recicláveis coletados. $\mathrm{O}$ fato de necessitar de maiores investimentos em equipamentos e sua respectiva manutenção também contribuiu para o custo;

- a ampliação do número de PEVs instalados na cidade, passando de 21 para 78 unidades ocorreu em setembro de 2002. O pico de aumento de custo (R\$/t) 
verificado nos meses de julho a outubro reflete os investimentos feitos para ampliar o programa no município;

- o custo unitário da coleta seletiva porta a porta é semelhante ao custo praticado para a coleta regular em Vitória, uma vez que se utiliza da mesma estrutura de coleta existente, a partir de contratos firmados com empresas especializadas; e,

- os valores negativos do custo unitário do programa de coleta seletiva por catadores autônomos reflete os meses em que a receita superou as despesas.

Em suma, a partir da aplicação dos Indicadores de Referência, foi possível identificar os pontos críticos, as principais dificuldades, do programa de coleta seletiva de Vitória, os quais são semelhantes aos aspectos que foram levantados e apresentados no capítulo 6, conforme apresentado no Quadro 13. 
Quadro 13 - Principais dificuldades para implantação e operação da coleta seletiva em municípios, segundo experiências levantadas nos municípios de São Bernardo do Campo, Porto Alegre, Florianópolis, Santo André e Vitória, aplicadas ao estudo de caso do município de Vitória.

\begin{tabular}{|c|c|c|c|}
\hline \multirow{3}{*}{$\begin{array}{l}\text { Principais dificuldades (pontos } \\
\text { críticos) para implantação e operação } \\
\text { da coleta seletiva nas experiências } \\
\text { municipais visitadas. }\end{array}$} & \multicolumn{3}{|c|}{$\begin{array}{l}\text { Análise face aos pontos críticos dos programas } \\
\text { de coleta seletiva de Vitória }\end{array}$} \\
\hline & \multicolumn{2}{|c|}{ Ponto Crítico } & \multirow{2}{*}{$\begin{array}{l}\text { Observações/ } \\
\text { Indicador(es) } \\
\text { relacionado(s) } \\
\end{array}$} \\
\hline & identificado & $\begin{array}{c}\text { não } \\
\text { identificado } \\
\end{array}$ & \\
\hline $\begin{array}{l}\text { Os custos de implantação e operação } \\
\text { da coleta seletiva, nos moldes adotados } \\
\text { pelos municípios, são altos; }\end{array}$ & $\mathbf{X}$ & & $\begin{array}{l}\text { custo do programa }(\mathrm{R} \$ / \mathrm{t}) \mathrm{e} \\
\text { custo de triagem }(\mathrm{R} \$ / \mathrm{t})\end{array}$ \\
\hline $\begin{array}{l}\text { A escala da coleta seletiva não } \\
\text { aumenta na mesma proporção dos } \\
\text { investimentos; }\end{array}$ & $\mathbf{X}$ & & $\begin{array}{l}\text { cobertura de atendimento } \\
\text { (hab) e IRMR }(\%)\end{array}$ \\
\hline $\begin{array}{l}\text { Falta equipe qualificada para } \\
\text { trabalhar, exclusivamente, com a } \\
\text { coleta seletiva; }\end{array}$ & & $\mathbf{X}$ & $\begin{array}{l}\text { ausência de indicadores } \\
\text { apurados }\end{array}$ \\
\hline $\begin{array}{l}\text { Faltam recursos para se realizar e } \\
\text { manter ações de divulgação e } \\
\text { motivação da população; }\end{array}$ & $\mathbf{X}$ & & IRMR (\%) \\
\hline $\begin{array}{l}\text { Falta o monitoramento da participação } \\
\text { da população que, geralmente, é baixa; }\end{array}$ & & $\mathbf{X}$ & IRMR (\%) \\
\hline $\begin{array}{l}\text { Falta metodologia de acompanhamento } \\
\text { e registro sistemático de informações; }\end{array}$ & & $\mathbf{X}$ & $\begin{array}{c}\text { ausência de indicadores } \\
\text { apurados }\end{array}$ \\
\hline $\begin{array}{l}\text { Decaimento gradual das quantidades } \\
\text { coletadas pela coleta seletiva; }\end{array}$ & $\mathbf{X}$ & & $\begin{array}{c}\text { IRMR }(\%) \text { e quantidade } \\
\text { de MR coletados } \\
\text { seletivamente ( } / \text { mês) } \\
\end{array}$ \\
\hline $\begin{array}{l}\text { Ausência e/ou variações do mercado de } \\
\text { recicláveis; }\end{array}$ & $\mathbf{X}$ & & $\begin{array}{l}\text { custo total do programa } \\
(\mathrm{R} \$ / \mathrm{t}) \text { e quantidade de itens } \\
\text { MR comercializados (un) }\end{array}$ \\
\hline $\begin{array}{l}\text { Ação dos catadores autônomos que } \\
\text { levam o material reciclável antes; }\end{array}$ & $\mathbf{X}$ & & $\begin{array}{l}\text { IRMR }(\%) \text { e quantidade } \\
\text { de MR coletados } \\
\text { seletivamente ( } / \text { mês }) \\
\end{array}$ \\
\hline $\begin{array}{l}\text { Crescimento acelerado do número de } \\
\text { catadores autônomos e dificuldade de } \\
\text { integração dos mesmos aos programas } \\
\text { estabelecidos pelos municípios; }\end{array}$ & $\mathbf{X}$ & & $\begin{array}{l}\text { IRMR }(\%) \text { e quantidade } \\
\text { de MR coletados } \\
\text { seletivamente ( } / \text { mês })\end{array}$ \\
\hline $\begin{array}{l}\text { Ausência de políticas públicas para } \\
\text { coleta seletiva, catadores e mercado de } \\
\text { recicláveis; }\end{array}$ & $\mathbf{X}$ & & $\begin{array}{l}\text { IRMR (\%) e quantidade de } \\
\text { itens MR comercializados } \\
\text { (un) }\end{array}$ \\
\hline Descontinuidades políticas. & & $\mathbf{X}$ & $\begin{array}{c}\text { quantidade de MR } \\
\text { coletados seletivamente } \\
\text { (t/mês) }\end{array}$ \\
\hline
\end{tabular}


Tem-se, assim, demonstrada a real aplicação prática do grupo de indicadores estabelecido para representar os diversos aspectos operacionais envolvidos em Programas de Coleta Seletiva.

\subsection{Pesquisa sobre a Participação}

Os resultados da pesquisa sobre a participação social na coleta seletiva estão apresentados a seguir, compondo-se respectivamente das fases metodológicas 3, 4 e5.

\subsection{1 - Pesquisa Qualitativa - Participação social na Coleta Seletiva}

A partir do desenvolvimento da etapa qualitativa (Fase 3), identificou-se fatores de motivação da população quanto à participação em Programas de Coleta Seletiva, levantou-se aspectos que impedem e/ou dificultam a participação da população e investigou-se a Hipótese 2:

O tipo de participação social é fator de maior ou menor sucesso dos programas de coleta seletiva, havendo diferentes respostas da população em relação à participação que podem ser agrupadas em: grupo cativo, de participação eventual e que não participa.

Os resultados qualitativos da Fase 3 foram tabulados e apresentados com base na metodologia de pesquisa adotada, o Método de Análise de Discurso do Sujeito Coletivo - DSC.

\section{Fase 3 - Método de Análise de Discurso do Sujeito Coletivo (DSC)}

Para fins de tabulação dos resultados do DSC, foram adotadas as terminologias:

EI = Etapa I - antes da ampliação dos Programas de Coleta Seletiva de Vitória;

EII = Etapa II - após ampliação dos Programas de Coleta Seletiva de Vitória;

QI = Questionário I - aplicado nos locais que possuem coleta seletiva implantada;

QII = Questionário II - aplicado nos locais que não possuem coleta seletiva implantada; e, 
$\mathrm{P}=$ Pergunta, que aparece seguido do número de referência utilizado no questionário.

A pesquisa foi repetida seis meses após a ampliação do Programa de Coleta Seletiva de Vitória, sendo que, nesta segunda etapa (EII), em todos os bairros pesquisados, existia a coleta seletiva, sendo utilizado um único questionário (QI).

A segunda etapa (EII) da pesquisa de campo foi realizada após veiculação na TV de uma campanha publicitária de divulgação da coleta seletiva na cidade.

A partir de setembro de 2002, o pessoal da prefeitura introduziu, junto à população do município, uma nova forma para separação dos resíduos sólidos urbanos que passaram a ser separados em "lixo seco" e "lixo úmido".

Acredita-se que tal fato tenha tido algum reflexo nos resultados obtidos.

Os resultados foram tabulados em função da etapa da pesquisa e modelo do questionário adotado, do sujeito coletivo (S), da idéia central (IC) e da ancoragem síntese (A) que são figuras metodológicas da Análise do Discurso do Sujeito Coletivo.

Tais figuras metodológicas fazem parte do método adotado, sendo conceituados pelos autores LEFÉVRE e LEFÉVRE (2002), como:

$\mathrm{S}=$ Sujeito Coletivo - terminologia utilizada para agrupar as respostas semelhantes de diversos indivíduos entrevistados para uma mesma pergunta. Sendo que, a partir do conjunto de respostas obtidas para uma mesma pergunta, pode-se identificar diversos Sujeitos Coletivos, os quais são diferenciados por um número de referência que vem após o símbolo $\mathrm{S}$.

IC = Idéia Central Síntese - é a descrição, da maneira mais sintética e precisa possível, dos depoimentos do grupo de indivíduos entrevistados, que compõem o sujeito coletivo $(\mathrm{S})$, o qual a idéia central está referenciada.

A = Ancoragem Síntese - é a descrição, de maneira sintética, de afirmações genéricas, de senso comum, que representam crenças, encontradas nas respostas, as quais foram utilizadas pelos indivíduos entrevistados para enquadrar alguma situação. DSC = Discurso do Sujeito Coletivo - que é um discurso síntese redigido a partir do agrupamento dos diversos Sujeitos Coletivos (S). 
Para viabilizar a análise dos resultados agrupou-se, nos Quadros 14 a 18, as respostas obtidas nas diversas etapas de desenvolvimento da pesquisa qualitativa (EI e EII), seguindo a ordem das perguntas constantes nos questionários aplicados na pesquisa.

\section{EI P1 - Você já ouviu falar de Coleta Seletiva? Fale um pouco sobre isso.}

EII P1 - Você já ouviu falar de Coleta Seletiva, da Reciclagem do lixo? Fale um pouco sobre isso.

Quadro 14 - Idéias Centrais e Ancoragem síntese referentes à pergunta P1

\begin{tabular}{|c|c|c|c|}
\hline $\begin{array}{c}\text { Etapa/ } \\
\text { Questionário }\end{array}$ & Sujeito Coletivo & Idéia Central Síntese & Ancoragem Síntese \\
\hline \multirow[b]{2}{*}{ EI QI } & $\begin{array}{c}\mathrm{S} 1 \\
(10 \text { pessoas })\end{array}$ & $\begin{array}{c}\text { Já ouviu falar, coleta } \\
\text { Seletiva refere-se ao lixo } \\
\text { e a sua separação. }\end{array}$ & $\begin{array}{c}\text { Coleta seletiva refere-se } \\
\text { ao lixo }\end{array}$ \\
\hline & $\begin{array}{c}\mathrm{S} 2 \text { e } \mathrm{S} 3 \\
(6 \text { pessoas })\end{array}$ & $\begin{array}{c}\text { Já ouvi falar, coleta } \\
\text { seletiva refere-se à } \\
\text { prefeitura }\end{array}$ & $\begin{array}{l}\text { Coleta Seletiva é um } \\
\text { projeto da prefeitura. } \\
\text { A coleta seletiva } \\
\text { conscientiza a população. }\end{array}$ \\
\hline \multirow{3}{*}{ EI QII } & $\begin{array}{c}\text { S1 e S2 } \\
(10 \text { pessoas })\end{array}$ & $\begin{array}{c}\text { Coleta seletiva é a coleta } \\
\text { de lixo domiciliar }\end{array}$ & $\begin{array}{c}\text { Coleta seletiva é a coleta } \\
\text { diária do lixo doméstico } \\
\text { feita todos os dias }\end{array}$ \\
\hline & $\begin{array}{c}\text { S3 e S4 } \\
\text { (12 pessoas) }\end{array}$ & $\begin{array}{l}\text { Coleta seletiva ajuda a } \\
\text { resolver o problema do } \\
\text { lixo }\end{array}$ & $\begin{array}{l}\text { Coleta seletiva é uma } \\
\text { coisa boa. } \\
\text { A coleta seletiva depende } \\
\text { de incentivo e informação } \\
\text { para a população. }\end{array}$ \\
\hline & $\begin{array}{c}\text { S5 } \\
\text { (11 pessoas) }\end{array}$ & $\begin{array}{c}\text { Coleta seletiva é separar } \\
\text { o lixo. }\end{array}$ & $\begin{array}{l}\text { Coleta seletiva é a } \\
\text { separação do lixo. }\end{array}$ \\
\hline \multirow[t]{3}{*}{ EII QI } & $\begin{array}{l}\mathrm{S} 1, \mathrm{~S} 2 \text { e } \mathrm{S} 3 \\
(21 \text { pessoas })\end{array}$ & $\begin{array}{l}\text { A coleta seletiva e a } \\
\text { reciclagem referem-se ao } \\
\text { lixo e a sua separação. }\end{array}$ & $\begin{array}{c}\text { A reciclagem é } \\
\text { importante } \\
\text { Coleta seletiva e } \\
\text { reciclagem é a separação } \\
\text { e o reaproveitamento do } \\
\text { lixo }\end{array}$ \\
\hline & $\begin{array}{c}\text { S4 } \\
\text { (1 pessoa) }\end{array}$ & $\begin{array}{l}\text { Nunca ouviu falar da } \\
\text { coleta seletiva }\end{array}$ & - \\
\hline & $\begin{array}{c}\text { S5 } \\
\text { (10 pessoas) }\end{array}$ & $\begin{array}{l}\text { A reciclagem do lixo } \\
\text { refere-se à prefeitura }\end{array}$ & $\begin{array}{l}\text { Lixo é responsabilidade } \\
\text { da prefeitura }\end{array}$ \\
\hline
\end{tabular}


A partir da tabulação dos resultados foi possível redigir os DSC's para o conjunto de respostas obtidas da aplicação dos questionários, os quais algumas vezes tornam-se repetitivos, para uma mesma pergunta.

Para tornar a sua análise e discussão mais objetiva, optou-se por apresentar neste capítulo os mais representativos, ficando o conjunto de DSC's obtidos, na íntegra, contido no anexo 4.

No Quadro 14 tem-se idéias centrais (IC) e ancoragem (A) síntese referentes à pergunta $1(\mathrm{P} 1)$ nas etapas I (E1P1), na qual foram aplicados dois questionários (QI e QII) e a etapa II (EIIP1), com apenas o questionário (QI).

Tabulando-se os resultados da pergunta 1 (P1), para a primeira etapa da pesquisa (EI) e questionário QI (locais atendidos pelo programa de coleta seletiva da prefeitura), foram obtidos três sujeitos coletivos (S1, S2 e S3) e dois Discursos do Sujeito Coletivo (DSC's), sendo que a análise dos DSC's produzidos indica que, a parcela da população entrevistada, tinha conhecimento da existência da coleta seletiva, a considerava importante mas tratava o tema com certo distanciamento e fora de sua rotina cotidiana.

\section{Idéia Central: Já ouvi falar, coleta seletiva refere-se à prefeitura}

\section{DSC EI QI P1 (S2 e S3)}

Coleta Seletiva do lixo é o projeto da prefeitura para separar o lixo que possa ser reciclado. Tenho visto, dentro desse projeto vários contêineres com lugares específicos aonde a população deve separar o seu próprio lixo.

Já ouvi falar aqui no bairro, mas não tenho maiores conhecimentos. Eles começaram a desenvolver este projeto a bem pouco tempo.

Acho um bom trabalho, uma boa medida, interessante porque ajuda a prefeitura. Quando o lixo vai todo junto, tem de separar.

A coleta seletiva conscientiza a população de que todos podemos ajudar. A prefeitura deveria trabalhar mais em cima de conscientizar o povo. 
Para os bairros onde ainda não existia coleta seletiva, ou seja, onde foi aplicado o questionário QII, foram obtidos cinco sujeitos coletivos (S1 a S5) e cinco Discursos do Sujeito Coletivo (DSC's).

A partir da análise dos DSC's obtidos verificou-se que os indivíduos entrevistados já haviam tido contato com a coleta seletiva, principalmente através da mídia, e que em parte faziam confusão entre a coleta seletiva e a coleta regular de resíduos sólidos domiciliares, conforme segue apresentado.

\section{Idéia Central: Coleta seletiva é a coleta de lixo domiciliar}

\section{DSC EI QII P1 (S2)}

Da coleta Seletiva? Do caminhão que passa para recolher o lixo todos os dias?

Coleta seletiva é a coleta do lixo doméstico que se faz todos os dias pela prefeitura.

A coleta de lixo aqui é boa, não há problema. Quase todo dia tem caminhão de lixo aí, apanha o lixo nas peixarias, tem sempre um varredor de rua também.

Ela melhorou muito de 1992 pra cá, nós estamos tendo uma participação constante da empresas. É uma atividade que só tem a ganhar.

O pessoal aqui tá conscientizado tem um horário determinado, que coloque o lixo exposto para que façam a coleta. Não tenho muita informação sobre isso.

\section{Idéia Central: Coleta seletiva ajuda a resolver o problema do lixo}

\section{DSC EI QII P1 (S3)}

Já ouvi falar sim. Vejo que está sendo bem executado, né?

A vizinhança está achando legal. Essa coisa do lixo orgânico, dos descartáveis, até mesmo para o trabalho das pessoas, melhora a seleção do lixo.

Eu achei uma coisa bacana. Quando tem vidros, latas, essas coisas que pode cortar o lixeiro porque está tudo misturado. Fica melhor separar logo né?

A gente vê em reportagem na televisão falando que é uma coisa boa o reaproveitamento do lixo, reciclagem do lixo. É uma coisa que poderia ser feito. É um programa que deve ser bem desenvolvido. 


\section{DSC EI QII P1 (S4)}

"Já ouvi falar em rádios, revistas, telejornais e outros meios de comunicação, conheço o trabalho embora a população não esteja bem conscientizada para isso. Só algumas grandes empresas, e alguns setores da prefeitura estão trabalhando com isso.

É um programa que a Prefeitura de Vitória, se não me engano, junto com o Estado, vem tentando desenvolver para tentar resolver Só que não é muito freqüente aqui. A gente não vê o trabalho efetivo deles.

Falta um trabalho de conscientização mostrando as pessoas que o lixo não era lixo. Nós não temos como trabalhar porque não há investimento nessa área.

As pessoas em Vitória já tem conhecimento maior da necessidade de se fazer a coleta seletiva, a separação do lixo, fazer com que o meio ambiente seja menos agredido e traga menor despesa ao município.

O problema do lixo que, por incrivel que pareça, daqui a alguns anos vai ser o grande filão de dinheiro do Estado e até da população."

\section{Idéia Central: Coleta seletiva é separar o lixo}

\section{DSC EI QII P1 (S5)}

Coleta seletiva? Ah! Lembrei. É aquele, que tem uns troços lá que coloca o lixo de plástico, vidro, papel, papelão né, essas coisas.

É separar o lixo. Essa coisa do lixo orgânico, dos descartáveis, até mesmo para o trabalho das pessoas. Coleta seletiva é separação de lixos recicláveis, os plásticos dos vidros e outras coisas mais, visando o reaproveitamento, a reciclagem desse material. Que podem se tornar novas matérias primas.

Então você separa lixo, separa o lixo, separa lata, separa papel.

O lixo orgânico também tem seu destino.

De um modo geral destaca-se no conjunto dos discursos encontrados, na primeira etapa da pesquisa (EI), a associação entre a coleta seletiva e os resíduos sólidos e a necessidade de haver maiores investimentos em divulgação e mobilização das pessoas 
para efetividade da coleta seletiva. Existindo a visão de que a coleta seletiva seria de responsabilidade da prefeitura.

Para a segunda etapa da pesquisa qualitativa (EII), onde se trabalhou exclusivamente com um questionário QI, identificou-se cinco sujeitos coletivos (S1 a S5) e quatro Discursos do Sujeito Coletivo (DSC's).

\section{Idéia Central: A coleta seletiva e a reciclagem referem-se ao lixo e a sua separação}

\section{DSC EII QI P1 (S1)}

A reciclagem é.... é sobre o... ai no momento eu esqueci aqui, eu não sei nem como me expressar. Mas a coletagem de lixo é sobre deixar a cidade limpa. Eu acho que muita gente aqui sabe, né ? E concorda também. Da recicragem também

Já tivemos representante da prefeitura em uma reunião explicando, sobre esse sentido. É o material que a gente usa e os resíduos são reaproveitados né?

Eu achei assim maravilhoso porque a gente divide é ... aqueles frascos né refrigerante, de várias coisas e coloca o lixo no lugar, alguns depósitos que a prefeitura já colocou em vários bairros.

Sempre se tem que tá juntando o lixo direitinho, tá separando os da reciclagem e tá colocando no dia certo no latão de lixo, né?

Acho muito bom, só que está sendo implantado mas não tá atendendo a comunidade como precisa. Eu acho que tá muito pouco, pouca caixa de coleta entendeu? Tem que ter mais.

\section{DSC EII QI P1 (S2)}

Aquele negócio de reciclagem, de dividir. Já ouvi. Separar o lixo do ... o lixo do que dá para reciclar É uma boa medida.

Do jeito que o pessoal tá fazendo tá indo bem né?

Tem que ter isso em todas as cidades não só em cidades grandes mas eu acho em cidades pequenas principalmente e meio rural.Eu acho que tem que ser obrigatório. A coleta seletiva e a reciclagem do lixo tem que ser abrangente. É o futuro de tudo 


\section{Idéia Central: Nunca ouviu falar da coleta seletiva}

\section{DSC EII QI P1 (S4)}

Eu junto meu lixo e eles levam, vejo aí falar de reciclagem mas nunca vi como é que faz. Eu sei o que a prefeitura fala, não entendo nada, só ouvi falar superficialmente. Eu não posso falar que eu não intendo não. Só sei que aqui nós pagamo eles panha o lixo e tudo, agora a coletage de lixo o que quê eles faz com o lixo eu não sei. Eles acabam indo lá na usina. Agora eu nuca fui lá na usina. Agora eu nunca fui lá, nunca vi, né? Aqui no bairro tá tudo certinho, o carro recolhe de noite, não tenho nada a reclamar.

Assim, observa-se que o conjunto dos discursos (DSC's), obtidos a partir da pergunta 1, denotam existir associação entre a coleta seletiva, reciclagem e separação dos resíduos sólidos, sendo a coleta seletiva considerada uma boa medida para a cidade. Uma parcela da população pesquisada mostra-se distanciada do tema coleta seletiva, atribuindo a responsabilidade pelo seu funcionamento ou não à prefeitura.

A seguir tem-se a pergunta 2, que trata da participação e/ou da coleta seletiva. Sendo uma pergunta aberta, que poderia resultar em respostas politicamente corretas, agregou-se à mesma duas perguntas complementares (P2.1 e P2.2). 


\section{QI P2 - Você participa da Coleta Seletiva em seu bairro?}

EI 2.1 Caso sim, como?

\section{QII P2 - Você estaria disposto a participa da Coleta Seletiva em seu bairro?}

\section{EI 2.1 Caso sim, como o(a) $\mathrm{Sr}$ (a) participaria? O que te motivaria a participar?}

Quadro 15 - Idéias Centrais e Ancoragem síntese referentes à pergunta P2/2.1

\begin{tabular}{|c|c|c|c|}
\hline Etapa/ Questionário & $\begin{array}{l}\text { Sujeito } \\
\text { Coletivo } \\
\end{array}$ & Idéia Central Síntese & Ancoragem Síntese \\
\hline \multirow[b]{2}{*}{ EI QI } & $\begin{array}{c}\text { S1 } \\
\text { ( } 07 \text { pessoas) }\end{array}$ & $\begin{array}{l}\text { Participo da Coleta } \\
\text { Seletiva separando o } \\
\text { lixo }\end{array}$ & $\begin{array}{c}\text { Muita coisa que vai para o } \\
\text { lixo se aproveita. }\end{array}$ \\
\hline & $\begin{array}{c}\text { S2 } \\
(01 \text { pessoa) }\end{array}$ & $\begin{array}{l}\text { Participo da Coleta } \\
\text { Seletiva junto à } \\
\text { comunidade. }\end{array}$ & $\begin{array}{l}\text { Participar da coleta seletiva } \\
\text { é exercer a cidadania }\end{array}$ \\
\hline \multirow{3}{*}{ EI QII } & $\begin{array}{l}\mathrm{S} 1, \mathrm{~S} 2 \text { e } \mathrm{S} 3 \\
\text { ( } 12 \text { pessoas) }\end{array}$ & $\begin{array}{l}\text { Participaria da coleta } \\
\text { seletiva separando o } \\
\text { lixo }\end{array}$ & $\begin{array}{l}\text { Participar da coleta seletiva } \\
\text { é exercer a cidadania }\end{array}$ \\
\hline & $\begin{array}{l}\text { S4, S5 e } \mathrm{S} 6 \\
\text { ( } 21 \text { pessoas) }\end{array}$ & $\begin{array}{c}\text { Participaria da coleta } \\
\text { seletiva pelo meio } \\
\text { ambiente }\end{array}$ & $\begin{array}{c}\text { A coleta seletiva melhora o } \\
\text { meio ambiente }\end{array}$ \\
\hline & $\begin{array}{c}\text { S7 } \\
\text { ( } 7 \text { pessoas) }\end{array}$ & $\begin{array}{l}\text { Participaria da coleta } \\
\text { seletiva se houvesse } \\
\text { organização e estrutura }\end{array}$ & $\begin{array}{c}\text { A participação depende da } \\
\text { aceitação da coleta seletiva } \\
\text { como algo correto e } \\
\text { benéfico. }\end{array}$ \\
\hline \multirow[t]{2}{*}{ EII QI } & $\begin{array}{c}\mathrm{S} 1 \text { e } \mathrm{S} 2 \\
(12 \text { pessoas })\end{array}$ & $\begin{array}{l}\text { Participo da Coleta } \\
\text { Seletiva junto à } \\
\text { comunidade. } \\
\end{array}$ & $\begin{array}{l}\text { Participar da coleta seletiva } \\
\text { é separar o lixo }\end{array}$ \\
\hline & $\begin{array}{c}\mathrm{S} 3 \\
\text { (4 pessoas) }\end{array}$ & $\begin{array}{l}\text { Participo da Coleta } \\
\text { Seletiva separando o } \\
\text { lixo } \\
\end{array}$ & $\begin{array}{c}\text { A população não está } \\
\text { educada para a coleta } \\
\text { seletiva. }\end{array}$ \\
\hline
\end{tabular}

Para fins de análise e tabulação de resultados, agrupou-se, respectivamente, as respostas afirmativas da pergunta 2 às respostas da pergunta 2.1 e as respostas negativas da pergunta 2 às respostas da pergunta 2.2, conforme consta nos Quadros 15 e 16.

A seguir apresenta-se os DSC's obtidos para a pergunta 2 (P2), associado à pergunta 2.1 (P2/2.1), a partir da tabulação dos resultados da primeira etapa da pesquisa (EI), 
para os questionários QI (locais atendidos pelo programa de coleta seletiva da prefeitura) e QII (locais sem coleta seletiva). A partir das respostas do questionário QI, obteve-se dois sujeitos coletivos (S1 e S2) e dois Discursos do Sujeito Coletivo (DSC's), conforme segue:

\section{Idéia Central: Participo da Coleta Seletiva separando o lixo}

\section{DSC EI Q1 P2/2.1 (S1)}

Participo. Colocando os lixos de acordo com... se é seco, se é molhado. O que eu acho que pode servir para alguém eu não misturo não. Muita coisa que vai para o lixo se aproveita.

A gente separa o que é vidro, que é plástico, que é lata, papel. E tem próximo aqui numa praça, a Prefeitura colocou um treco especial para se colocar.

\section{Idéia Central: Participo da Coleta Seletiva junto à comunidade}

\section{DSC EI Q1 P2/2.1 (S2)}

Como líder comunitária dizer que não participaria seria fugir do meu direito de cidadania e ajudar a minha comunidade.

Eu acredito que tem pessoas aqui já participam dessa coleta seletiva. Meu caso é verificar, fazer um campanha junto a comunidade."

O trabalho do líder de coleta do lixo seria maior incentivo a população para que participe. Não adianta ter contêiner lê e ninguém ir lá colocar.

Para o questionário QII, obteve-se sete sujeitos coletivos (S1 a S7) e sete Discursos do Sujeito Coletivo (DSC's). 


\section{Idéia Central: Participaria da coleta seletiva separando o lixo}

\section{DSC EI QII P2/2.1 (S2)}

Se houvesse oportunidade, eu participaria fazendo a separação em minha residência e incentivando os vizinhos.

Ia ajudar em alguma coisa, eu acho que falta incentivo a população de ter consciência sobre, eles próprios nas residências separarem o lixo, essa coisa de ... essa coisa do cuidado, acho que falta isso.

A questão do lixo é um problema muito sério no mundo em geral, no nosso país a comunidade é a principal arma para que a coleta seja feita de forma eficaz.

Se todo mundo fizer a gente faz. É bom é interessante, diminuiu o risco para quem vai colher o lixo, essas coisas todas.

\section{DSC EI QII P2/2.1 (S3)}

Participaria sim se não for me locomover demais. Pelo menos a gente veria o bairro limpo. Isso é uma coisa para melhoraria do bairro, a gente precisa de colaborar e também participar.

Eu gostaria que tivesse condições de ser feito, a gente separaria o lixo para colocar nos recipientes adequados.

Agora sair da minha casa para passar para os outros eu não posso porque eu tenho o meu trabalho. Seria uma coleta seletiva "domestical”.

\section{Idéia Central: Participaria da coleta seletiva pelo meio ambiente}

\section{DSC EI QII P2/2.1 (S4)}

Eu iria ajudar porque melhoraria muito o meio em que vivemos, gerar no caso mais emprego lá fora, estaria ajudando também a tirar o lixo da rua. Limpeza do bairro, melhor qualidade de vida dos moradores e uma cidade limpa.

Eu participaria separando o lixo.

Me motivaria se fosse um trabalho bem feito, troço mais organizado, direitinho. Saber que estou contribuindo para resolver um problema ecológico. Saber que esse 
material que estou separando para a reciclagem não vai ficar poluindo nossos rios, nossas terras. É bom para o meio ambiente. É uma coisa que a gente contribuiria para natureza de certa forma

Todos esses materiais, eles vão para os aterros sanitários. $O$ dinheiro gasto com a coleta de lixo, o aterro sanitário, agredindo o meio ambiente, ele é alto, quando você faz a coleta seletiva traz menor custo para o município e essa verba pode ser destinada para áreas sociais.

Eu acho que a organização é cuidado com a preservação ambiental.

\section{DSC EI QII P2/2.1 (S6)}

É tão questionado que o brasileiro joga tanta coisa no fora, o lixo é tão desprezado e muita gente vive até disso, coletando latinha, coletando plástico para sobreviver. Então de repente, é uma coisa mais correta, seletiva mesmo de separar o lixo.

O que motivaria a mim, motivaria a todos, seria a limpeza pública organização da nossa cidade, do nosso bairro, até ajudaria a educar mais a população. Que hoje em dia, é triste!

\section{Idéia Central: Participaria da coleta seletiva se houvesse organização e estrutura}

\section{DSC EI QII P2/2.1 (S7)}

Dependendo de como a administração vem fazendo, a gente também participa. Primeiro tem que saber como é que vai fazer, ser orientado.O convite de alguém né? O que mais me motivaria seria colocar pontos estratégicos, para que não haja bagunça na rua, como lixo esparramado em todo o lugar ou como tem aí.

O mais importante da coleta seletiva é um local apropriado. É preciso ter um local específico, porque qualquer coisa que você fala em relação a coleta de lixo incomoda a comunidade, se você coloca uma caixa na frente do cara ali, ele pode não gostar porque todo mundo vai jogar lixo ali, entendeu?

Porque realmente para levar até o local que a prefeitura coloca fica longe da casa, a pessoa tem preguiça e acaba não indo. 
Tudo que a população aceita como algo correto e benefício para si próprio é válido para que todo mundo participe.

Os DSC's resultantes da pergunta 2/2.1, questionários QI e QII, tratam do modo da motivação em participar da coleta seletiva e, por meio deles, percebe-se que a maioria das pessoas entendem que participar é separar o lixo, existindo uma parcela que, também, ajudaria na divulgação e trabalhos voluntários.

A motivação em participar apresenta-se relacionada ao exercício de cidadania, melhoria da limpeza do bairro, do problema do resíduo sólido, do ambiente e, em menor escala, a geração de empregos. A organização do programa de coleta seletiva, também, está ligada à participação.

Quanto aos aspectos que impedem e/ou dificultam a participação da população, temse obtido: falta de incentivo, divulgação, orientação de como proceder e necessidade de deslocamentos a grandes distâncias para entregar o resíduo separado.

Para a segunda etapa (EII) da pesquisa, tem-se que 16 entrevistados, num total de 32, afirmaram participar da coleta seletiva, resultando em três sujeitos coletivos (S1, S2 e S3) e três Discursos do Sujeito Coletivo (DSC's).

\section{Idéia Central: Participo da Coleta Seletiva junto à comunidade}

\section{DSC EII Q1 P2/2.1 (S1)}

Participo falando com o pessoal e reciclando o meu lixo, separando o lixo do molhado e do seco. Fazendo essa divisão do lixo doméstico. Separando o lixo pra reciclagem e lixo pra não reciclagem.

A associação de moradores faz um acompanhamento através da conscientização aos moradores para que estejam colocando o lixo no horário determinado pela prefeitura, explicando o que é reciclável ou não.

A associação comunitária hoje dá informativo do jornal dizendo aos moradores que adeque ao sistema, aquela coleta seletiva do lixo seco e do lixo molhado. A secretaria de meio ambiente até nos deu parabéns por ter a melhor participação dentre outras comunidades. 


\section{DSC EII Q1 P2/2.1 (S2)}

Não tem o dia do lixo né? Terça e sexta feira e os outros dias do molhado. A gente participa separando o lixo no nosso condomínio, justamente fazendo essa divisão do lixo doméstico.

Segue essa regra ai da prefeitura. Da forma que eles decidiram de fazer aquela coleta seletiva do lixo seco e do lixo molhado. Na separação do Lixo

Em casa já deixam o lixo separado, então desço com o lixo separado já. Aí o coletor vem e leva. Então eu acho que é muito importante, né? Fazer coleta, separar o lixo. Não custa, né? É muito aproveitoso!

\section{Idéia Central: Participo da Coleta Seletiva separando o lixo}

\section{DSC EII Q1 P2/2.1 (S3)}

Como eu participo é ... agora eu não sei ... não sei te informar. Juntá o lixo para o povo levá, no caso?

Eu sei que nós panha o no... o lixo todo dia e eles panha, o coletor vem e leva.

Separo o lixo seco do lixo ... esse lixo podre né, resto de comida. Mas agora eles não estão nem recolhendo, sabe por que? O pessoal coloca ... não separa né, deixa lá. Ontem mesmo num recolheram. Tá tudo lá no meio da rua. Que o pessoal que bota fora de hora, de dia né, não tem um horário certo pra colocar.

O povo ainda não está ainda assim ... conscientizado do que tem que fazer e o que tá acontecendo é que o nosso bairro tá ficando muito sujo.

Meu lixo eu coloco nos lugar próprio que o caminhão já passe e pegue nunca deixo na minha porta se tivesse um local próprio que nas ruas colocassem os lixos seria melhor, às vezes o caminhão do lixo demora muito a passar . E esse lixo ficando jogado nas portas passa gente chutando. Então eu acho importante aqui tivesse um lugar próprio pra cada morador colocar o lixo. É um meio de educar ... facilitar ao morador

Para este grupo de respostas, observa-se a assimilação do conceito lixo seco e lixo úmido e a continuidade da visão de que a responsabilidade da coleta seletiva é da 
prefeitura, podendo a associação de moradores apoiar o programa na divulgação. $\mathrm{O}$ aspecto da falta de conscientização da população foi destacado.

Para verificar a Hipótese 2, que trata da participação da população em programas de coleta seletiva, buscou-se identificar nos resultados da pergunta $2 / 2.1$ a existência do grupo cativo e de participação eventual.

$\mathrm{Na}$ EIQI verifica-se que o pensamento associado ao sujeito S1 expressa a participação consciente (grupo cativo) e no caso do sujeito S2 a participação estaria associada a fatores contingenciais (grupo de participação eventual)

A EIQII foi desenvolvida em bairros onde não havia coleta seletiva implantada, não permitindo tal análise.

Para EIIQI observa-se uma nítida diferença no pensamento associado ao discurso do sujeito S1, que denota uma participação consciente (grupo cativo) e dos sujeitos S2 e S3, onde a participação estaria relacionada à regra estabelecida pela prefeitura (grupo de participação eventual).

$\mathrm{Na}$ Hipótese 2 formulada, está prevista a existência de um terceiro grupo, dentro da população alvo da coleta seletiva, caracterizado pela não adesão ao programa.

O grupo que não participa está expresso nos resultados da pergunta 2 (P2) /2.2, tabulados no quadro 16.

A seguir apresenta-se, para a pergunta 2 (P2), associado à pergunta $2.2(\mathrm{P} 2 / 2.2)$, os resultados da etapa da pesquisa EI, para os questionários QI (locais atendidos pelo programa de coleta seletiva da prefeitura) e QII (locais sem coleta seletiva).

A tabulação das respostas do questionário EI QI, resultou em quatro sujeitos coletivos (S1, S2, S3 e S4) e três Discursos do Sujeito Coletivo (DSC's). 
QI P2 - Você participa da Coleta Seletiva em seu bairro?

2.2 Caso não, porque?

QII P2 - Você estaria disposto a participar da Coleta Seletiva em seu bairro?

\subsection{Caso não, porque?}

Quadro 16 - Idéias Centrais e Ancoragem síntese referentes à pergunta P2/2.2

\begin{tabular}{|c|c|c|c|}
\hline Etapa/ Questionário & $\begin{array}{l}\text { Sujeito } \\
\text { Coletivo }\end{array}$ & Idéia Central Síntese & Ancoragem Síntese \\
\hline \multirow[b]{2}{*}{ EI QI } & $\begin{array}{l}\mathrm{S} 1, \mathrm{~S} 2 \text { e } \mathrm{S} 3 \\
(06 \text { pessoas })\end{array}$ & $\begin{array}{c}\text { Não participo por falta } \\
\text { de oportunidade e/ou } \\
\text { acomodação }\end{array}$ & $\begin{array}{l}\text { Pessoas que trabalham fora } \\
\text { não tem tempo para } \\
\text { participar da coleta seletiva. }\end{array}$ \\
\hline & $\begin{array}{c}\text { S4 } \\
\text { ( } 03 \text { pessoas) }\end{array}$ & $\begin{array}{c}\text { Não participo por falta } \\
\text { de incentivo }\end{array}$ & $\begin{array}{l}\text { A coleta seletiva depende de } \\
\text { incentivo e informação para a } \\
\text { população. }\end{array}$ \\
\hline EI QII & $\begin{array}{c}\text { S1 } \\
(04 \text { pessoas })\end{array}$ & Não participaria & - \\
\hline \multirow[t]{2}{*}{ EII QI } & $\begin{array}{l}\mathrm{S} 1, \mathrm{~S} 2 \text { e S3 } \\
\text { ( } 11 \text { pessoas) }\end{array}$ & $\begin{array}{c}\text { Não participo por falta } \\
\text { de informação e } \\
\text { estrutura }\end{array}$ & $\begin{array}{l}\text { A coleta seletiva depende de } \\
\text { estrutura e informação para a } \\
\text { população. }\end{array}$ \\
\hline & $\begin{array}{c}\mathrm{S} 4 \\
(5 \text { pessoas })\end{array}$ & $\begin{array}{c}\text { Não participo por falta } \\
\text { de tempo }\end{array}$ & $\begin{array}{l}\text { Pessoas que trabalham fora } \\
\text { não têm tempo para } \\
\text { participar da coleta seletiva. }\end{array}$ \\
\hline
\end{tabular}

Idéia Central: Não participo por falta de oportunidade e/ou acomodação

\section{DSC EI Q1 P2/2.2 (S1)}

Não sou eu que levo o lixo para a rua. Esse negócio fica lá em casa a cargo da mulher ... então não participo.

\section{DSC EI Q1 P2/2.2 (S2)}

Falta oportunidade. Só tem uma coleta no bairro ... dificulta pra gente. O local que é de coleta seletiva é longe da minha casa. O caminhão que se passa em frente a casa não faz a coleta seletiva. 


\section{DSC EI Q1 P2/2.2 (S3)}

Fico a maior parte do tempo fora de casa, na hora que o lixeiro passa eu não estou em casa. A moça que trabalha aqui faz a coleta no meu lixo doméstico. Ela não separa, tem que estar orientando. Eu mesmo não levo lá e não vejo sendo colocado. Sei que vou criar um caso com a minha secretária, se eu pedir para ela ir e ela não for. Nesse caso nem peço, porque sei que é um mal menor.

Para locais não atendidos com coleta seletiva, onde se utilizou o questionário QII, tem-se:

\section{Idéia Central: Não participaria}

\section{DSC EI QII P2/2.2 (S1)}

Eu não sei, tem que saber como é para fazer. No meu bairro ainda não tem coleta separada, né? Pra mim eu acho que não daria por causa do meu serviço.

De um modo geral os sujeitos coletivos identificados em EIQI justificam a não participação devido à falta de oportunidade, tempo e incentivo e, em EIQII, é devida à falta de orientação e à inexistência de estrutura. Não se verificou, de forma explícita, a rejeição ao programa de coleta seletiva.

Em seguida, são apresentados os discursos dos sujeitos coletivos referentes à pergunta $2 / 2.2$, encontrados na segunda etapa da pesquisa, ou seja, após a ampliação, pela prefeitura, do Programa de Coleta Seletiva a todos bairros envolvidos na pesquisa .

\section{Idéia Central: Não participo por falta de informação e estrutura}

\section{DSC EII QI P2/2.2 (S1)}

Não. Eu participo no meu ... da minha casa né? Eu tiro o lixo de dentro de casa ... procuro colocar na hora que ... o gari vai passar. 
Lá ainda não tem marcado os lugares de colocar o lixo. A caixa é lá em baixo, aqui em cima não tem uma caixa. Então meu lixo é colocado ensacolado e o rapaz pega toda à tarde.

Não sei quem tá no meio, que mexe com isso. Só sei o horário que os gari passa para recolher os lixos.

\section{DSC EII QI P2/2.2 (S2)}

Não participo porque não tenho informação, não sei como é que funciona. Ninguém falou nada para mim participar, nem entendo bem essas coisas.

É porque eu acho que não tem necessidade, que tem muita gente na comunidade, né?

E o custo também fica muito caro, porque a pessoa vai comprar quantos centos de sacos de lixo pra botar um em cada um. Onde eu resido tem diversas caixas de lixo pra botar qualquer tipo de lixo, ai eu coloco lá. Porque aqui o lixo é recolhido tudo junto né?

Não fazem coleta seletiva, eles fazem coleta coletiva. Aqui só tem aquele contêiner ali perto do ponto de ônibus.

\section{DSC EII QI P2/2.2 (S3)}

Nós no comércio não fazemos a seletiva, separar vidro, plástico, isso aí não. Haveria assim como se fosse só uma pré, né ? Aqui nosso ramo aqui é cópias Então nós separamos o lixo do papel e o lixo que a gente usa. Por exemplo, o alimento de seco de molhado aqui a gente faz. Mas dentro desse seco né, seria feita a triagem.

\section{Idéia Central: Não participo por falta de tempo}

\section{DSC EII QI P2/2.2 (S4)}

Não, nem em casa fico. Sempre estou fora de casa, trabalhando. Eu trabalho muito fora, não tenho tempo, não de recolher lixo, de separar, colocar lixo na rua.

Não sou eu que mexo com isso lê em casa. Não despertei pra isso entendeu?! Meu filho, deixei pra ele!! 
Nos resultados de EII observa-se que a não participação na coleta seletiva estaria associada a falta de informação, estrutura e tempo. Em ambas etapas (EI e EII) verifica-se a idéia de que participar da coleta seletiva é uma atividade trabalhosa, incompatível com a disponibilidade de tempo de quem trabalha fora.

A pergunta 3 trata das causas relacionadas a descontinuidades dos programas de coleta seletiva, estando seus resultados apresentados no quadro 17.

\section{P3 - Em certos lugares, os programas de coleta seletiva começam bem e acabam} sendo deixados de lado com o tempo. Porque você acha que isso acontece ?

Quadro 17 - Idéias Centrais e Ancoragem síntese referentes à pergunta P3

\begin{tabular}{|c|c|c|c|}
\hline $\begin{array}{c}\text { Etapa/ } \\
\text { Questionário }\end{array}$ & $\begin{array}{l}\text { Sujeito } \\
\text { Coletivo }\end{array}$ & Idéia Central Síntese & Ancoragem Síntese \\
\hline \multirow[b]{2}{*}{ EI QI } & $\begin{array}{c}\mathrm{S} 1 \\
(09 \text { pessoas }) \\
\end{array}$ & $\begin{array}{l}\text { Acontece por falta de } \\
\text { interesse e acomodação }\end{array}$ & $\begin{array}{c}\text { A população não dá o valor devido } \\
\text { à coleta seletiva }\end{array}$ \\
\hline & $\begin{array}{c}\text { S2 e S3 } \\
(08 \text { pessoas })\end{array}$ & $\begin{array}{l}\text { Acontece por falta de } \\
\text { educação, } \\
\text { conscientização e } \\
\text { estímulo. }\end{array}$ & $\begin{array}{l}\text { A coleta seletiva funciona em locais } \\
\text { onde a população é esclarecida. } \\
\text { A coleta seletiva precisa de } \\
\text { estímulo permanente. }\end{array}$ \\
\hline \multirow[b]{2}{*}{ EI QII } & $\begin{array}{l}\text { S1, S2 e S3 } \\
\text { (14 pessoas) }\end{array}$ & $\begin{array}{l}\text { Acontece por falta de } \\
\text { educação, } \\
\text { conscientização e } \\
\text { estímulo. }\end{array}$ & $\begin{array}{l}\begin{array}{c}\text { As pessoas se acomodam com o } \\
\text { tempo }\end{array} \\
\text { O povo não está conscientizado } \\
\begin{array}{c}\text { Falta estímulo do poder público } \\
\text { para a coleta seletiva }\end{array}\end{array}$ \\
\hline & $\begin{array}{c}\text { S4 e S5 } \\
\text { (19 pessoas) }\end{array}$ & $\begin{array}{l}\text { Acontece por falta de } \\
\text { estrutura e divulgação }\end{array}$ & $\begin{array}{c}\text { A divulgação dos resultados da } \\
\text { coleta seletiva leva a maior } \\
\text { participação } \\
\text { Falta continuidade nos programas } \\
\text { de coleta seletiva }\end{array}$ \\
\hline \multirow[t]{2}{*}{ EII QI } & $\begin{array}{c}\text { S1 e } \mathrm{S} 2 \\
(25 \text { pessoas })\end{array}$ & $\begin{array}{l}\text { Acontece por falta de } \\
\text { educação, } \\
\text { conscientização e } \\
\text { estímulo. }\end{array}$ & $\begin{array}{l}\text { O povo não está conscientizado } \\
\text { As pessoas se acomodam com o } \\
\text { tempo }\end{array}$ \\
\hline & $\begin{array}{c}\text { S3 e S4 } \\
\text { (7 pessoas) }\end{array}$ & $\begin{array}{l}\text { Acontece por falta de } \\
\text { estrutura e divulgação }\end{array}$ & $\begin{array}{l}\text { Falta estímulo e estrutura do poder } \\
\text { público para a coleta seletiva }\end{array}$ \\
\hline
\end{tabular}


A tabulação das respostas, na etapa de pesquisa EI, permitiu identificar três sujeitos coletivos (S1, S2 e S3) e três Discursos do Sujeito Coletivo (DSC's) para a pergunta $\mathrm{P}$, questionário QI.

\section{Idéia Central: Acontece por falta de interesse e acomodação}

\section{DSC EI QI P3 (S1)}

Acontece porque as pessoas não participam, não dão valor. Esse trabalho que é muito importante. Falta interesse da população, pode acontecer de ter no bairro e as pessoas não usarem. A prefeitura acaba tirando em forma de protesto contra a população.

O povo não preserva o que é nosso. A maioria do brasileiro é bastante relaxado.

O povo não continua tudo que começa, tem o incentivo de se iniciar, daí a pouco aquilo para, o povo parece que não tem aquela vontade de ver cosas bonitas.

As pessoas não costumam ajudar, colaborar, então acabam esquecendo, não continuando.

Falta à pessoa arrumar um tempo para separar, e levar no local onde é feita a coleta. A pessoa se acomoda muito fácil com as coisas né?

Os catadores passam e pegam papelão, plástico que interessa e morador vai ficando acomodado.

Estão trabalhando direitinho né, coletando o lixo. O povo não respeita, fica tudo sujo, o povo é culpado né.

\section{Idéia Central: Acontece por falta de educação, conscientização e estímulo}

\section{DSC EI QI P3 (S2)}

Acontece devido à educação. Em Jardim Camburi o pessoal tem um nível um pouco melhor. Sabem que isso ai é pra evitar proliferação de doenças, de vir ratos. Então aqui funciona. 


\section{DSC EI QI P3 (S3)}

Falta de estímulo do poder público, conscientização e educação do povo. A prefeitura junto com as lideranças, está faltando isso, uma conscientização com a comunidade.

Falta incentivo por parte da prefeitura, do governo de fazer mais campanhas evidenciando a importância do projeto.

Devia incentivar e fazer prosseguir o projeto. É necessário pelos meios de comunicação, fazer essa propaganda.

Falta esclarecimento, falta mesmo uma campanha nesse sentido.

Tudo que você faz e não dá corda, até o relógio para. Então a coleta de lixo está fadada a não ser bem sucedida se não houver um estimulo.

Para locais onde não existia a coleta seletiva e questionário QII, tem-se:

\section{Idéia Central: Acontece por falta de educação, conscientização e estímulo}

\section{DSC EI QII P3 (S1)}

Acontece por falta de participação, relaxo da comunidade.

Desinteresse. Falta de colaboração. É justamente isso, preguiça da pessoa sair de casa para levar até o local onde são colocadas as lixeiras da prefeitura.

A pessoa começa e depois se acomoda. Tem que ser feito com amor e com capricho, as coisas andam, mas se começar a relaxar, acaba.

\section{DSC EI QII P3 (S2)}

É uma coisa que deve ser feita em conjunto, com todas as pessoas da cidade.

Algumas pessoas já tem o vício, o hábito de jogar as coisas no chão, por falta as vezes de instrução, conhecimento, orientação.

A coleta seletiva já é uma coisa mais complicada. Se uma pessoa não tem preparo pra pegar o lixo que ela tem e jogar na lata, para ele jogar numa coleta seletiva vai ser muito mais dificil ainda. 
Eu acho que a comunidade tem que ser vigilante, tem que marcar presença constante. A partir do momento em que você é contribuinte, tem mais que direitos de estar cobrando.

Não há muita colaboração para isso. As pessoas pensam assim: Ah, a gente já paga os impostos, o lixo tem mais é que jogar de qualquer jeito. Acomodação das pessoas, né?

O brasileiro é muito acomodado e preguiçoso para separar os negócios. Depende do povo, né?

As autoridades tem que incentivar e não deixar passar no esquecimento.

\section{DSC EI QII P3 (S3)}

Precisa de incentivo, que a prefeitura ou órgão responsável espalhe panfletos, conscientize a população.

Devia ter uma equipe de casa em casa, fazendo um trabalho para conscientizar as pessoas.

É uma responsabilidade do poder público local, não deixar esquecido. O município tem que criar incentivos com cooperativas, tirar esses catadores de ruas, fazer reuniões com as comunidades, fazer com que esta questão da coleta seletiva, da seleção do lixo, esteja presente e nunca seja esquecido. É um trabalho que deve ser feito a longo prazo.

Qualquer projeto, quando se torna uma prática comum, fica evidenciado por todos e todos tem o dever dessa participação. A gente faria uma coleta seletiva normalmente.

\section{Idéia Central: Acontece por falta de estrutura e divulgação}

\section{DSC EI QII P3 (S4)}

Não houve orientação adequada.

No momento em que é colocado a lixeira da prefeitura as pessoas podem até ter um incentivo para fazer essa coleta. 
O povo não está conscientizado. Talvez porque não foi divulgado o resultado, o benefício. Se for feito um tipo de propaganda, de conscientização a nível de meios de comunicação do benefício que esta coleta está fazendo acredito que as pessoas vão ter incentivo de continuar, colaborar fazendo a coleta seletiva. Elas não devem saber a verdade, qual o destino desse lixo, para quê está sendo útil esta separação que está fazendo o lixo.

Falta esclarecimento com o pessoal do bairro, conscientização da população e também órgãos que trabalham na divulgação, apoio, pessoas para poder incentivar as pessoas a trabalharem desta forma.

\section{DSC EI QII P3 (S5)}

Acontece pelas forças governamentais e municipais, o descaso dos órgãos, que começam e não dão continuidade não fazem um trabalho de divulgação para incentivar a pessoa a dar continuidade a esse processo.

Muitas vezes é interesse de algumas pessoas para que possam implantar esse tipo de coisa. Assim que termine o interesse é tudo abandonado, largado, como a gente vê muito em nosso país.

As pessoas desenvolvem aquilo para fazerem propaganda, as vezes na época de política. Quando as redes de televisão deixam de lado, param de vigiar, deixam distorcer, os contratos ficam ao rigor da banalidade até dar tudo errado.

Isso acontece não só em Vitória, mas também em outras cidades que já tem isso implantado.

É responsabilidade do poder público local, principalmente o municipal, e não pode deixar ao esquecido, basta dizer que o brasileiro tem memória curta.

O município tem que se fazer presente a cada momento, criar incentivos com cooperativas, tirar esses catadores de ruas, fazer reuniões com as comunidades, fazer com que esta questão da coleta seletiva, da seleção do lixo, esteja presente e nunca seja esquecida ... Isso é um trabalho que deve ser feito ao longo prazo.

Falta organização, o pessoal acaba desistindo. A prefeitura não dá assistência, culpo mais a prefeitura. 
Após ampliação da coleta seletiva, ou seja, a etapa EII, tem-se:

\section{Idéia Central: Acontece por falta de educação, conscientização e estímulo}

\section{DSC EII QI P3 (S1)}

Acontece porque o povo não está muito informatizado. $O$ nosso povo ainda não estava preparado para esse tipo de trabalho, a rejeição do povo é grande nesse sentido.

O povo não tem educação para seguir umas normas dessas.

O povo não colabora, não tem consciência que tem que jogar no lugar certo. Aí vai juntando lixo pela rua, o cachorro vai espalhando e vira aquela bagunça.

Aquele negoço de terça-feira lixo seco e lixo molhado parece que não deu certo, que a população não entendeu.

Não há a educação, pra pessoa incutir isso na cabeça é ter isso como modo de vida. As pessoas começam naquela empolgação da implantação e depois esquecem com o tempo. O pessoal vai se desgastando, perde o incentivo.

As pessoas esqueciam. Deixavam pra lá e acabavam esquecendo. Teria que ter um trabalho mais forte para conscientizar o cidadão.

Á coisa importante isso ai de coleta.

Um acompanhamento quase que diário faz com as pessoas se conscientiza que a coleta seletiva é o melhor caminho para evitar doenças.

\section{DSC EII QI P3 (S2)}

Acontece por falta de interesse, pessoas folgadas!

A pessoa se cômoda ... relaxa porque não que mesmo ajudar, não quer colaborar. Tiro a conclusão de mim mesmo.

Não tenho tempo para separar, é muita coisa pra fazer, não dá pra mim né?

A coleta seletiva toma um pouquinho de tempo das pessoas.

Falta espaço, a gente não tem como ter as lixeiras separadas, o espaço é pequeno. A pessoa vai acumular muito lixo dentro de casa. 
Se eu junto meu lixo e jogo na escada, por exemplo, to cooperando pra uma doença pra mim depois ou pros meus filhos, pros meus netos. O pessoal não sente assim, dar de si a utilidade humana pra ... ter saúde para as crianças e pra outras pessoas. Isso é terceiro mundo!

Não é culpa da pessoa que organizou, mas culpa da população.

A prefeitura está fazendo a parte dela, já tem alguns postos de coleta de lixo, mas basta saber se os moradores também querem.

O pessoal da prefeitura pegam, mas os moradores da rua começam a jogar, jogar, eles se desanimam e acabam deixando.

\section{Idéia Central: Acontece por falta de estrutura e divulgação}

\section{DSC EII QI P3 (S3)}

Acontece porque falta administração Depende muito da prefeitura, da empresa encarregada.

Aqui em Vitória a coleta de lixo é muito bem feita, muito bem orientada, muito bem administrado. Eu não tenho nada a reclamar, sempre coletaram direitinho, sem problema nenhum. Aqui eis panha todo dia à noite.

\section{DSC EII QI P3 (S4)}

Talvez falta informação ou panfletagem. Não tem uma propaganda, não tem explicação correta pra população. Falta de orientação pra população mesmo! A reeducação dos moradores é um dos motivos de dar certo em toda comunidade.

Um pouco é relaxamento da prefeitura mesmo né? Eles não dão as condições devidas.

Aqui, por exemplo, o local que ela tá instalada não é certo. Teria que ser um local assim de mais movimento, onde as pessoas passam e veêm que ali é o lugar de colocar o lixo.

Os dados obtidos a partir da pergunta 3 reforçam alguns aspectos citados nas respostas dadas às perguntas 1 e 2 , em especial quanto à insuficiência de ações de 
mobilização, divulgação e informação à população, por parte do parte do poder público, quanto à coleta seletiva.

A falta de divulgação dos resultados da coleta seletiva foi destacada como fator relevante para sua descontinuidade.

Tem-se relacionado esta questão, ainda, à acomodação e ao desinteresse da população, fatores associados a aspectos culturais e nível de instrução do povo brasileiro que, em geral, tem o hábito de jogar lixo no chão. O descrédito relativo a ações oriundas do poder público também foi citado.

Parte dos sujeitos coletivos identificados trata da questão como uma ação a ser desenvolvida em conjunto pelo poder público e a comunidade.

Observa-se o consenso de que as ações de divulgação e mobilização devem ser contínuas.

$\mathrm{Na}$ seqüência têm-se apresentado os resultados da pergunta 4, na qual a pessoa entrevistada era convidada a falar mais sobre o assunto, caso desejasse (Quadro 18). 
P4 - Teria mais alguma coisa a falar ?

Quadro 18 - Idéias Centrais e Ancoragem síntese referentes à pergunta P4

\begin{tabular}{|c|c|c|c|}
\hline $\begin{array}{c}\text { Etapa/ } \\
\text { Questionário }\end{array}$ & $\begin{array}{l}\text { Sujeito } \\
\text { Coletivo } \\
\end{array}$ & Idéia Central Síntese & Ancoragem Síntese \\
\hline \multirow{3}{*}{ EI QI } & $\begin{array}{c}\mathrm{S} 1 \\
(10 \text { pessoas }) \\
\end{array}$ & Não teria mais o que falar & \\
\hline & $\begin{array}{c}\mathrm{S} 2 \\
(03 \text { pessoas })\end{array}$ & $\begin{array}{c}\text { Falta divulgação e } \\
\text { estrutura para a Coleta } \\
\text { Seletiva }\end{array}$ & $\begin{array}{l}\text { Falta divulgação da Coleta } \\
\text { Seletiva }\end{array}$ \\
\hline & $\begin{array}{c}\mathrm{S} 3 \\
(03 \text { pessoas })\end{array}$ & $\begin{array}{l}\text { Falta educação e } \\
\text { consciência para a } \\
\text { coleta seletiva. }\end{array}$ & $\begin{array}{c}\text { O povo precisa ser educado sobre } \\
\text { a limpeza da cidade. }\end{array}$ \\
\hline \multirow{3}{*}{ EI QII } & $\begin{array}{c}\text { S1 e S2 } \\
(10 \text { pessoas })\end{array}$ & $\begin{array}{l}\text { A coleta seletiva pode } \\
\text { trazer benefícios }\end{array}$ & $\begin{array}{l}\text { A coleta seletiva só funciona onde } \\
\text { a limpeza é organizada } \\
\text { O povo precisa ser educado sobre } \\
\text { a limpeza da cidade }\end{array}$ \\
\hline & $\begin{array}{c}\mathrm{S3} \\
\text { (4 pessoas) }\end{array}$ & $\begin{array}{l}\text { Falta estrutura para a } \\
\text { coleta seletiva }\end{array}$ & $\begin{array}{l}\text { A prefeitura não atende a todos } \\
\text { com a coleta seletiva }\end{array}$ \\
\hline & $\begin{array}{c}\text { S4 } \\
(18 \text { pessoas })\end{array}$ & Não teria mais o que falar & - \\
\hline \multirow{3}{*}{ EII QI } & $\begin{array}{l}\mathrm{S} 1, \mathrm{~S} 2 \text { e S3 } \\
(9 \text { pessoas })\end{array}$ & $\begin{array}{l}\text { A coleta seletiva traz } \\
\text { benefícios }\end{array}$ & $\begin{array}{l}\text { A coleta seletiva depende de } \\
\text { investimento e incentivo. } \\
\text { Muita gente sobrevive do lixo. }\end{array}$ \\
\hline & $\begin{array}{c}\text { S4 } \\
\text { (4 pessoas) }\end{array}$ & $\begin{array}{c}\text { Falta educação e } \\
\text { consciência para a coleta } \\
\text { seletiva }\end{array}$ & $\begin{array}{c}\text { O povo precisa ser educado sobre } \\
\text { a limpeza da cidade }\end{array}$ \\
\hline & $\begin{array}{c}\text { S5 } \\
(19 \text { pessoas })\end{array}$ & Não teria mais o que falar & - \\
\hline
\end{tabular}

A seguir apresenta-se os DSC's obtidos para a pergunta P4, a partir da tabulação dos resultados da primeira etapa da pesquisa (EI), para os questionários QI (locais 
atendidos pelo programa de coleta seletiva da prefeitura) e QII (locais sem coleta seletiva). A partir das respostas do questionário QI, obteve-se três sujeitos coletivos (S1, S2 e S3) e três Discursos do Sujeito Coletivo (DSC's), para QII teve-se quatro sujeitos coletivos (S1,S2,S3 e S4) e quatro DSC's.

\section{Idéia Central: Não teria mais o que falar}

\section{DSC EI QI P4 (S1)}

Não. Só isso mesmo.

\section{Idéia Central: Falta divulgação e estrutura para a Coleta Seletiva}

\section{DSC EI QI P4 (S2)}

Falta divulgação. Falta fazer propaganda melhor. Além da coleta seletiva poderia ser a separação do lixo como latas, garrafas, papéis. Aqui a prefeitura colocou essa separação, mas não teve muita divulgação.

O comércio está colocando nas caixinhas, mas está faltando propaganda, falar mais para as pessoas.

Poucos contêineres. Se houvesse em mais lugares talvez as pessoas se dispusessem a colocar mais. Se tivesse um aqui na esquina ficaria mais fácil, eu mesmo colocaria no carro para levar, é coisa para se programar.

Acho que seria uma boa para a comunidade, já tem condomínio que estão usando a coleta seletiva para fins lucrativos.

\section{Idéia Central: Falta educação e consciência para a coleta seletiva}

\section{DSC EI QI P4 (S3)}

O povo ainda não tem educação, de estar respeitando o horário do lixo, de estar ensacolando, até mesmo amarrando o seu lixo para evitar doenças. É importante a Prefeitura estar fazendo junto com a comuniddade um trabalho de conscientização.

O pessoal da rua suja a rua, a prefeitura varre e varre, mas não adianta porque o povo não tem educação. 
É feita a coleta seletiva e as próprias pessoas de rua abrem as comportas e derrubam esse lixo todo, onde dificulta a limpeza.

A partir da análise dos comentários verifica-se que a coleta seletiva é vista como algo benéfico, e que a insuficiência das ações de divulgação e mobilização mais uma vez é destacada.

Para os bairros sem coleta seletiva, onde se utilizou o questionário QII, tem-se:

\section{Idéia Central: A coleta seletiva pode trazer benefícios}

\section{DSC EI QII P4 (S1)}

É uma coisa importante, essa coisa assim do meio ambiente, que poderia se colocado em prática.

Essa classificação eu acredito que nós temos muito que ganhar, uma qualidade de vida melhor. As próprias pessoas deviam se interessar mais um pouquinho para melhorar, porque começa deles mesmos.

A gente vê que a coleta de lixo normal já é tão dificultosa, então essa coisa do seletivo seria mais ainda. Então, deveria partir do principio de organizar essa coleta normal, para depois partir para um projeto maior.

A qualidade de vida depende de uma limpeza constante dos bairros e participação dos moradores colocando o lixo em seus lugares apropriados.

Posso falar sobre os ratos também, a gente tá aqui num tormento danado.

\section{Idéia Central: Falta estrutura para a coleta seletiva}

\section{DSC EI QII P4 (S3)}

A prefeitura de Vitória não tem esse trabalho. Tem aí algumas coisas com relação à coleta seletiva espalhada na nossa ilha. Alguns bairros tem, outros não.

A coleta seletiva, assim como o lixo também tem que ter um lugar específico público, não em frente da minha casa.

Se há um órgão competente para isso, deveria tomar providências efetivas. 
Quanto ao recolhimento de lixo, somos bem servidos, regularmente, não posso me queixar não.

\section{Idéia Central: Não teria mais o que falar}

\section{DSC EI QII P4 (S4)}

Não, não tenho mais nada a para comentar. Mais ou menos por esse lado aí. No momento só isso mesmo.

Nos bairros não atendidos pela coleta seletiva do município, verifica-se nos DSC's a expectativa positiva em relação à futura implantação do programa pela prefeitura. Sendo que no discurso do sujeito coletivo S3, destaca-se a ressalva de que os recipientes para armazenar os resíduos sólidos devem existir, desde que não estejam em frente à sua moradia.

Como resultados da etapa EII, realizada após ampliação da coleta seletiva, tem-se:

\section{Idéia Central: A coleta seletiva traz benefícios}

\section{DSC EII QI P4 (S3)}

Importante a coleta seletiva, muita gente até sobrevive desse lixo né!

Uma lâmpada quebrada, um vidro quebrado, a gente não botar no lixo junto com as outras coisas que pode ocasionar um acidente para quem tá trabalhando.

A gente pode ajudar as outras pessoas a sobreviver fazendo reciclagem no lixo. Basta a conscientização da população em fazer a coleta seletiva e ter mais programas de incentivo a coleta seletiva.

Continuar fazendo a coleta que os outros faz a recicragem por aí.

\section{Idéia Central: Falta educação e consciência para a coleta seletiva}

\section{DSC EII QI P4 (S4)}

As pessoas que não cuida, que não zelar. A limpeza depende de mim. 
O povo acha que serviço ... teria que ser feito pela prefeitura e todos os dias a coleta total do lixo para que a cidade ficasse limpa.

Tem bairro que a gente vê desmazelado.É por causa da população. As pessoas que jogam lixo de qualquer maneira, em qualquer lugar.

É o horário, né? Em muitos lugares eles passam da hora de coleta de lixo. Cada um tem a sua parte, todo mundo tem a sua participação. Eles avisaram o no radio e na televisão que não pode colocar fora do horário e eles colocam. Sabe por causa de quê ? Eles querem tirar de dentro de casa e colocar na rua.

Os coletor vem todos os dias, tem muita gente que joga saco de lixo pelas escadas. É por isso que as pessoas não vivem bem. Você fala fulano não age assim aí ele fala você é otário. Falta de educação mesmo, depende da gente.

Fazendo uma análise geral da pergunta P4, verifica-se que foi oferecida aos entrevistados a oportunidade de expressar livremente comentários adicionais sobre a coleta seletiva, sendo que na etapa EI, dos 48 entrevistados, 20 manifestaram opinião e em EII, dos 32 entrevistados, 19 falaram alguma coisa.

Como resultados de $\mathrm{P} 4$, encontram-se referências a qualidade de vida associada à limpeza dos bairros e ao fato de que o adequado funcionamento da coleta seletiva seria decorrência da organização e estrutura da coleta regular.

Cabe ressaltar que, para fins de sorteio dos bairros, cuja população seria entrevistada na pesquisa qualitativa considerou-se, dentre outros aspectos, a existência de coleta seletiva nas modalidades PEVs, organizações de catadores autônomos e porta a porta. Observa-se nos resultados a menção da coleta seletiva por PEVs e especificamente na segunda etapa (EII) também a coleta seletiva porta a porta. A coleta seletiva por organização de catadores autônomos, realizada pela ASCAMARE, não foi citada.

Encontram-se alguns comentários sobre catadores informais, para os quais os resíduos sólidos seriam uma forma de sobrevivência, como é o caso do DSC EII QI P4 (S3).

Ainda persiste a visão de que a atividade de catador não seja uma profissão e, sim, uma busca de sobrevivência, para pessoas que estão à margem da sociedade, não havendo organização e, portanto, não estando associado à coleta seletiva. 


\subsection{2 - Pesquisa Quantitativa - Participação social na Coleta Seletiva}

A etapa quantitativa da pesquisa sobre a participação foi realizada no período de agosto a outubro de 2002 com objetivo de fornecer informações de caráter complementar aos resultados obtidos na fase 3, sendo desenvolvida através de:

- Enquête realizada via site da Prefeitura (Fase 4)

- Questionário aplicado aos funcionários da prefeitura e da empreiteira, envolvidos com a coleta seletiva (Fase 5) .

Para a enquête (Fase4) obteve-se a participação de 73 pessoas, principalmente durante o mês de agosto, ou seja, nas primeiras semanas que foi colocada no ar.

Para a pesquisa realizada na prefeitura de Vitória (Fase 5), obteve-se a participação de 32 pessoas, conforme apresentado no Quadro 19.

Quadro 19 - Amostra da pesquisa quantitativa sobre a participação na coleta seletiva realizada na prefeitura de Vitória. Vitória, 2002.

\begin{tabular}{|c|c|c|l|}
\hline Setor & $\begin{array}{c}\mathbf{N}^{\circ} \\
\text { Questionários } \\
\text { respondidos }\end{array}$ & $\begin{array}{c}\mathbf{N}^{\circ} \text { de termos } \\
\text { de } \\
\text { consentimento }\end{array}$ & \multicolumn{1}{|c|}{ Perfil do Entrevistado } \\
\hline Usina de Lixo & 09 & 07 & $\begin{array}{l}\text {.pessoal técnico nível superior } \\
\text {.pessoal administrativo nível médio } \\
\text {.pessoal operacional nível médio }\end{array}$ \\
\hline $\begin{array}{c}\text { Departamento de } \\
\text { Limpeza Pública }\end{array}$ & 10 & 10 & $\begin{array}{l}\text {.pessoal técnico nível superior } \\
\text {.pessoal administrativo nível médio } \\
\text {.pessoal operacional nível médio }\end{array}$ \\
\hline $\begin{array}{c}\text { Secretário e Sub- } \\
\text { Secretário }\end{array}$ & 02 & 02 & $\begin{array}{l}\text {.dirigentes da Secretaria gestora do } \\
\text { Projeto - nível superior }\end{array}$ \\
\hline $\begin{array}{c}\text { Departamento de } \\
\text { Educação Ambiental }\end{array}$ & 04 & - & $\begin{array}{l}\text {.pessoal técnico de nível médio e } \\
\text { superior }\end{array}$ \\
\hline Empresa A & 02 & 02 & $\begin{array}{l}\text {.pessoal operacional de nível médio e } \\
\text { superior }\end{array}$ \\
\hline Empresa B & 05 & 05 & $\begin{array}{l}\text {.pessoal administrativo nível médio } \\
\text {.pessoal técnico nível médio }\end{array}$ \\
\hline
\end{tabular}


As empresas A e B prestam serviços de limpeza e conservação de vias públicas, coleta de lixo e destino final em todo o município de Vitória, a partir de contrato firmado com a administração municipal.

\subsubsection{1 - Tratamento Estatístico de Dados - Analise Descritiva}

A partir da coleta de dados, utilizando-se de questionários aplicados via site e outros submetidos a profissionais da prefeitura e das empresas contratadas (fases 4 e 5), foi realizada análise descritiva dos dados.

O questionário aplicado via site foi mais reduzido, assumindo o formato de uma enquête e o questionário aplicado ao pessoal que atua na coleta seletiva de Vitória foi mais detalhado, mantendo-se as mesmas perguntas da enquête e acrescentando-se outras. Ao final, foram obtidos 101 questionários respondidos, sendo 73 via site.

Como o objetivo destes dois levantamentos de dados era o mesmo, e tratava-se de uma amostra pequena optou-se pela tabulação em conjunto dos dados, que seguem apresentados.

Parte I - identificação do informante

Quanto a procedência dos questionários, a maioria deles foram respondidos via internet ( 68,2\%), seguidos dos obtidos via pessoal da prefeitura através da Secretaria Municipal de Serviços -SEMURB (11,2\%), responsável pela limpeza pública, da Usina de Lixo (8,4\%), responsável pela triagem dos resíduos coletados e do departamento de Educação Ambiental com (3,7\%). A participação das empresas contratadas (A e B) corresponde a $(6,6 \%)$

Quanto ao grau de instrução, 58,9\% dos participantes da pesquisa, possuíam nível superior, seguidos de 36,6\% pessoas com segundo e primeiro grau. 6,9\% dos participantes possuíam pós graduação.

Quanto à renda familiar tem-se a maioria $(51,4 \%)$ possui renda superior a $\mathrm{R} \$$ $2.001,00$, seguido da faixa de $\mathrm{R} \$ 501,00$ a $\mathrm{R} \$ 1.000,00$ com $16,8 \%$ dos participantes da pesquisa. $2,14 \%$ das pessoas pesquisadas informaram possuir renda familiar entre $\mathrm{R} \$ 1.001,00$ e $\mathrm{R} \$ 2.000,00$. A minoria (9,3\%) possui renda de até $\mathrm{R} \$ 500,00$. 
Observa-se que $89,7 \%$ de todos entrevistados, responderam afirmativamente a questão que tratava da existência de coleta seletiva em suas residências. Tal resultado, sofre influência do fato de que a maioria dos participantes desta pesquisa foram voluntários, simpatizantes ou interessados em coleta seletiva, que responderam voluntariamente a enquête disponibilizada na internet.

Ressalta-se que o grupo de pessoas que afirmaram separar o lixo em suas residências teve como origem principal a enquête via internet. Por outro lado, a maioria dos entrevistados da prefeitura e empresas contratadas informaram não participa da coleta seletiva $(32,3 \%)$ ou participa a menos de 6 meses $(26,5 \%)$. Sendo que a prefeitura municipal possui coleta seletiva implantada desde 1998 e vem discutindo e planejando a ampliação de seu programa de coleta seletiva desde 2001.

Para a parcela dos funcionários entrevistados da prefeitura e empreiteiras entrevistados que responderam afirmativamente quanto à existência da coleta seletiva, perguntou-se sobre o tempo da participação.

A tabela 10 apresenta os dados obtidos.

Tabela 10 - Há quanto tempo você participa da coleta seletiva? (*)

\begin{tabular}{l|c|c}
\hline \multicolumn{1}{c|}{ Tempo } & Freq. & \% \\
\hline Há menos de 6 meses & 9 & 26,5 \\
de 6 meses a 1 ano & 5 & 14,7 \\
entre 1 a 2 anos & 5 & 14,7 \\
Há vários anos & 4 & 11,8 \\
Não participa & 11 & 32,3 \\
\hline Total & $\mathbf{3 4}$ & $\mathbf{1 0 0 , 0}$ \\
\hline
\end{tabular}

(*) Pergunta não inclusa no questionário respondido pela internet.

Quanto aos meios pelos quais a população obtém informações sobre coleta seletiva, verificou-se a importância das campanhas de divulgação e a grande influência da mídia através da TV, jornais e revistas. Na pesquisa, essa pergunta foi apresentada com a opção de escolha múltipla. A tabela 11 e o gráfico 36 apresentam os resultados. 
Tabela 11 - Fontes de informação sobre coleta seletiva de lixo

\begin{tabular}{l|c|c}
\hline Meios & Freq. & \% \\
\hline Escola & 20 & 18,7 \\
TV & 48 & 44,9 \\
Jornais e revistas & 51 & 47,7 \\
Internet & 34 & 31,8 \\
Campanhas de divulgação & 59 & 55,1 \\
Outros & 50 & 46,7 \\
\hline
\end{tabular}

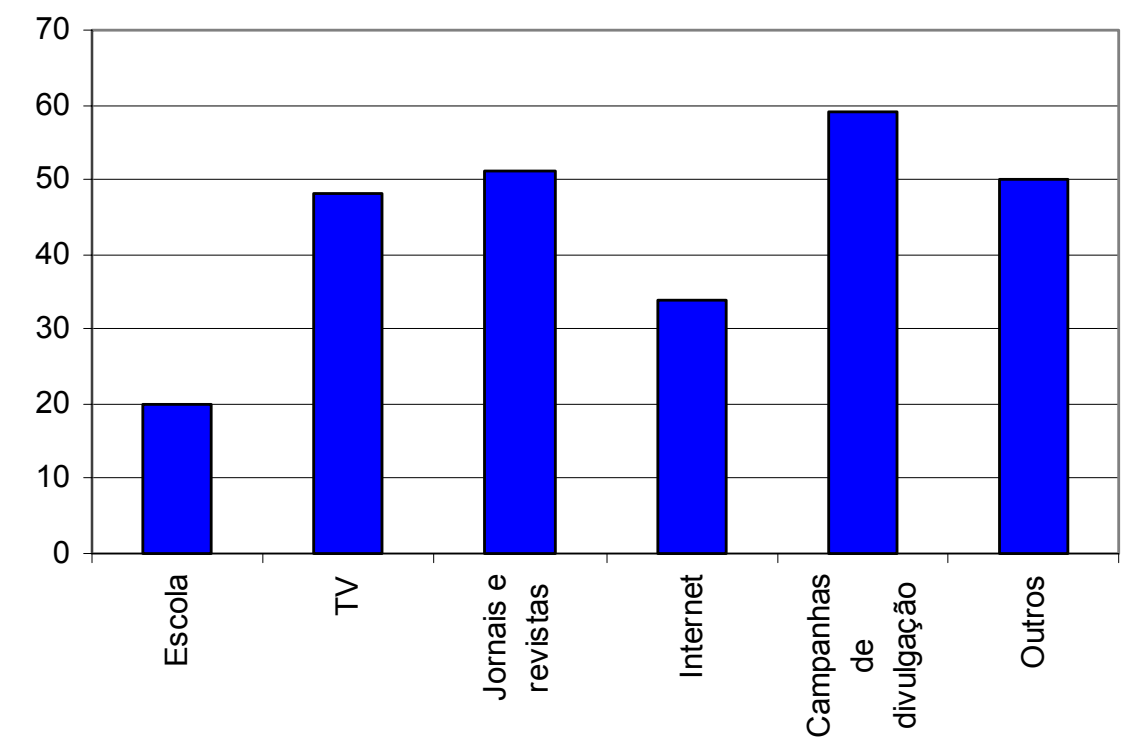

Gráfico 36 - Fontes de informação sobre coleta seletiva de lixo.

No questionário aplicado ao pessoal da prefeitura e empresas contratadas perguntouse ainda sobre outros meios de obtenção de informações sobre coleta seletiva, obtendo-se 17 respostas apresentadas na tabela 12.

Tabela 12 - Outros meios de obtenção de informação sobre coleta seletiva.

\begin{tabular}{l|c|c}
\hline \multicolumn{1}{c|}{ Meios } & Freq. & $\mathbf{\%}$ \\
\hline Trabalhos sobre o tema & 8 & 47,0 \\
Palestras e cursos & 1 & 5,9 \\
PMV & 2 & 11,8 \\
SEMMAM & 1 & 5,9 \\
SEMURB & 1 & 5,9 \\
SEMMAM e SEMURB & 2 & 11,8 \\
Usina de Triagem e Compostagem de Vitória & 1 & 5,9 \\
Vendo o coletor na rua (PEV) & 1 & 5,9 \\
\hline Total & $\mathbf{1 7}$ & $\mathbf{1 0 0 , 0}$ \\
\hline
\end{tabular}

(*) Pergunta não inclusa no questionário respondido pela internet. 
Para as pessoas que afirmaram não conhecer a coleta seletiva na enquête, perguntouse se estariam dispostas a participar da coleta seletiva, obtendo-se 93,2\% de respostas afirmativas. O resultado obtido reflete o fato de existir pré-disposição a participar da coleta seletiva nas pessoas que espontaneamente resolveram participar da enquête.

$\mathrm{Na}$ seqüência perguntou-se nos dois questionários (fases 4 e 5) sobre a motivação para participar da coleta seletiva, sendo permitido escolher mais de uma resposta. Verificou-se que os maiores fatores da motivação para o grupo pesquisado, são o meio ambiente $(70,1 \%)$ seguido de qualidade de vida e limpeza $(66,4 \%)$ educação (56,1\%). Apenas 15,9\% das respostas referiu-se a campanhas de divulgação.

O gráfico 37 apresenta os resultados.

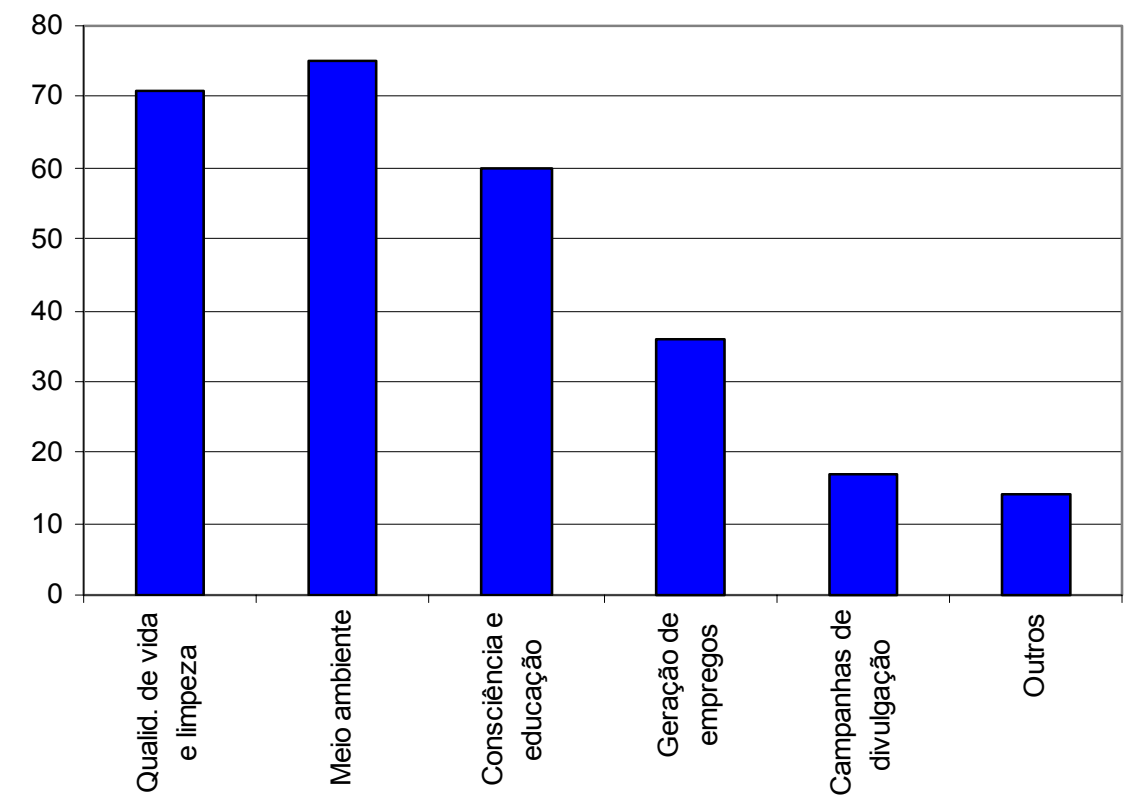

Gráfico 37 - Motivação para participar da coleta seletiva.

Tais aspectos também foram citados na pesquisa qualitativa (Fase 3).

Para o pessoal da Prefeitura e empresas contratadas (fase 5), perguntou-se sobre o desempenho da etapa piloto da coleta seletiva (1990 a 2002), obtendo-se 47,1\% das respostas ótimo e bom e 35,3\% de regular, o que denota a aprovação do programa perante o pessoal envolvido com planejamento e gestão do programa de coleta seletiva de Vitória . 
Para este mesmo grupo (fase 5) perguntou-se quanto ao tempo possível de armazenamento do lixo reciclável nas residências dos entrevistados e o grau de dificuldade para a separação do lixo, tem-se os resultados na tabela 13.

Tabela 13 - Tempo de armazenamento do resíduo reciclável nas casa ou local de trabalho dos entrevistados $(*)$

\begin{tabular}{l|c|c}
\hline \multicolumn{1}{c|}{ Tempo } & Freq. & $\mathbf{\%}$ \\
\hline 1 a 2 dias & 12 & 35,3 \\
1 semana & 20 & 58,8 \\
2 semanas & 1 & 2,9 \\
1 mês & 1 & 2,9 \\
\hline Total & $\mathbf{3 4}$ & $\mathbf{1 0 0 , 0}$ \\
\hline
\end{tabular}

(*) Pergunta não inclusa no questionário respondido pela internet.

Verifica-se que a maioria $(58,8 \%)$ informou que poderia armazenar o lixo reciclável por até uma semana, seguido do tempo de 1 a 2 dias (35,5\%). Quanto ao grau de dificuldade obteve-se $61,8 \%$ de respostas considerando fácil a separação do lixo para a reciclagem e $23,5 \%$ considerando como um grau médio de dificuldade.

Como resultado da pergunta: as informações que recebe sobre coleta seletiva são suficientes? tem-se que a maioria dos entrevistados da prefeitura $(82,4 \%)$ considerou como suficiente às informações que recebe sobre coleta seletiva.

Em seguida o questionário solicitava que fosse feita avaliação sobre o novo modelo de PEV, denominado de ECOPOSTO pela prefeitura, conforme apresentado no Quadro 20. 
Quadro 20. Características positivas e negativas do novo modelo de PEV instalado na cidade em relação ao anterior, segundo respostas dos questionários. $(*)$

\begin{tabular}{|l|l|}
\hline \multicolumn{1}{|c|}{ Positiva } & \multicolumn{1}{c|}{ Negativa } \\
\hline mais simples e funcional & $\begin{array}{l}\text { maior dificuldade na entrega de } \\
\text { recicláveis de maior volume }\end{array}$ \\
\hline facilita o usuário (lixo seco e lixo úmido) & $\begin{array}{l}\text { boca apertada (abertura para colocação } \\
\text { de recicláveis é estreita) }\end{array}$ \\
\hline mais qualidade & facilita vandalismo e pichações \\
\hline mais moderno & $\begin{array}{l}\text { condições desfavoráveis para coleta } \\
\text { (muito lenta) }\end{array}$ \\
\hline bom modelo & menor visibilidade (menos colorido) \\
\hline mais prático, higiênico & aparência de banheiro químico \\
\hline maior visibilidade & \\
\hline robusto e harmônico & \\
\hline condições favoráveis para coleta e transporte & \\
\hline permite menor vandalismo & \\
\hline maior oferta/ quantidade de ECOPOSTOS & \\
\hline estimula a separação nas residências & \\
\hline
\end{tabular}

(*) Pergunta não inclusa no questionário respondido pela internet.

As respostas quanto à avaliação do novo modelo de PEV adotado, apresentadas no Quadro 20, demonstram que, no momento da pesquisa, o pessoal da prefeitura e empresas contratadas apontavam mais características positivas que negativas quanto a adequação de equipamento para as necessidades da coleta seletiva.

A maior preocupação referia-se ao tamanho da abertura, existente no $\mathrm{PEV}$, para colocação de recicláveis. A qual era propositalmente estreita para coibir vandalismo e evitar o uso indevido do equipamento para acondicionamento de objetos volumosos e resíduos orgânicos de maior porte, como coco verde, não compatível com as papeleiras adotadas pelo município.

Para os participantes da pesquisa via internet perguntou-se sobre o interesse em ter informações adicionais sobre a coleta seletiva, tendo-se os resultados apresentados no Quadro 21. 
Quadro 21 - Citações sobre o interesse em ter informações adicionais sobre a coleta seletiva, segundo respostas dos questionários. $\left({ }^{*}\right)$

\begin{tabular}{|c|c|}
\hline Tema & Citações sobre \\
\hline \multirow{5}{*}{$\begin{array}{l}\text { Operação de } \\
\text { Coleta }\end{array}$} & Como será feita essa coleta pela PMV? \\
\hline & $\begin{array}{l}\text { Como é feita a coleta, a conscientização da população, qual o objetivo } \\
\text { desta coleta, os benefícios que trazem, os recursos utilizados e etc. }\end{array}$ \\
\hline & $\begin{array}{l}\text { De que forma seria feita essa coleta? Quais os dias que seriam recolhidos } \\
\text { os vários tipos de lixo, etc. }\end{array}$ \\
\hline & $\begin{array}{l}\text { Gostaria de saber se a PMV pretende fazer esta coleta em domicílio ou se } \\
\text { será apenas nos pontos que hoje recebem os materiais recicláveis? }\end{array}$ \\
\hline & $\begin{array}{l}\text { Quando a PMV voltará a fazer a coleta seletiva na empresa que trabalho } \\
\text { (Saveiros Camuy Rano LTDA - Ilha da Fumaça) tendo em vista que a } \\
\text { coleta foi interrompida sem aviso, ficando o lixo acumulado }\end{array}$ \\
\hline \multirow{10}{*}{$\begin{array}{l}\text { Divulgação/ } \\
\text { Informação }\end{array}$} & $\begin{array}{l}\text { A forma como a informação tem chegado é autoritária, a PMV deve } \\
\text { respeitar o direito do cidadão, empurar uma situação sem discursão para } \\
\text { posterior adesão é no mínimo irracional e ... }\end{array}$ \\
\hline & $\begin{array}{l}\text { Campanhas educativas, educação ambiental, informações para a população } \\
\text { através dos meios de comunicação (rádio, tv, jornal, etc...). }\end{array}$ \\
\hline & $\begin{array}{l}\text { Creio que a PMV deve melhorar as informações. Pouca gente de Jardim } \\
\text { Camburi, por exemplo, sabe onde está o ecoposto. }\end{array}$ \\
\hline & $\begin{array}{l}\text { É necessária uma cartilha informativa com trabalho educativo e campanha } \\
\text { de divulgação e talvez programar } 1 \text { ou } 2 \text { dias/semana para recolhimento do } \\
\text { lixo selecionado. O novo coletor tem uma boca muito pequena. }\end{array}$ \\
\hline & $\begin{array}{l}\text { Gostaria só de sugerir que houvessem mais campanhas educativas sobre } \\
\text { coleta seletiva de lixo. }\end{array}$ \\
\hline & $\begin{array}{l}\text { Por que não foi feito um trabalho informativo nos bairros onde as lixeiras } \\
\text { seletivas foram colocadas? }\end{array}$ \\
\hline & $\begin{array}{l}\text { Qual deve ser o procedimento da família para organizar e concluir a coleta } \\
\text { seletiva? }\end{array}$ \\
\hline & $\begin{array}{l}\text { Quando a mesma vai começar a atuar na Praia do Canto (Região do Barro } \\
\text { Vermelho - parte alta). Só tem ecoposto na Av. Rio Branco e na Rua Dr. } \\
\text { João Carlos de Souza. }\end{array}$ \\
\hline & $\begin{array}{l}\text { Quais os atuais pontos de coleta, identificando-os por bairro e nome de rua } \\
\text { onde foi colocado. Saberíamos o ponto mais próximo de nossa residência. }\end{array}$ \\
\hline & Se realmente terá a coleta seletiva nos domicílios. \\
\hline \multirow[t]{3}{*}{$\begin{array}{l}\text { Triagem e } \\
\text { Destinação }\end{array}$} & $\begin{array}{l}\text { Gostaria de saber se a coleta domiciliar convencional passará por triagem } \\
\text { ou irá diretamente para o aterro sanitário neste primeiro momento de } \\
\text { implantação do projeto? }\end{array}$ \\
\hline & Para onde irão os lixos não recicláveis? \\
\hline & Qual a maior usina de lixo do Brasil? \\
\hline
\end{tabular}


Quadro 21 - Citações sobre o interesse em ter informações adicionais sobre a coleta seletiva, segundo respostas dos questionários.(*). Cont.

\begin{tabular}{|c|c|}
\hline Tema & Citações sobre \\
\hline \multirow{5}{*}{$\begin{array}{l}\text { Recipiente de } \\
\text { Coleta }\end{array}$} & Gostaria que existissem mais coletores para esse tipo de recolhimento. \\
\hline & $\begin{array}{l}\text { O importante é instalar várias caixas coletoras de lixo seletivo. Somente a } \\
\text { facilidade em depositar o lixo separado é que vai incentivar os moradores. }\end{array}$ \\
\hline & $\begin{array}{l}\text { Os novos coletores realmente funcionam, já que têm uma entrada para } \\
\text { todos os tipos de materiais? O coletor antigo tinha várias entradas e o } \\
\text { material ficava todo separado. O antigo não era melhor? }\end{array}$ \\
\hline & $\begin{array}{l}\text { Qual seria a viabilidade de instalar postos de coleta pelo menos num espaço } \\
\text { de duas quadras? }\end{array}$ \\
\hline & $\begin{array}{l}\text { Quando serão instaladas nas ruas lixeiras adequadas que promovam a } \\
\text { coleta seletiva? Não ajudariam a conscientizar sobre a necessidade de } \\
\text { separar o sólido do úmido? Quando irá começar campanha. de } \\
\text { conscientização? }\end{array}$ \\
\hline \multirow{5}{*}{ Condomínios } & $\begin{array}{l}\text { Como proceder se os outros condôminos não aceitam separar o lixo? } \\
\text { Haverá multas e como serão cobradas? }\end{array}$ \\
\hline & $\begin{array}{l}\text { Em um condomínio grande, a coleta é feita por funcionários, acho difícil } \\
\text { organizar a separação num ambiente heterogêneo. Num prédio pequeno se } \\
\text { tem uma relação pessoal com quem busca o lixo separado. }\end{array}$ \\
\hline & $\begin{array}{l}\text { Gostaria de receber folders, cartazes explicativos para fazer um painel no } \\
\text { meu condomínio. Sou síndica do prédio e estou lançando uma campanha } \\
\text { Nosso lixo é precioso e necessito de informações. }\end{array}$ \\
\hline & $\begin{array}{l}\text { Gostaria de saber se já existe algum programa que possa viabilizar este } \\
\text { tipo de coleta em um edifício de apartamentos? }\end{array}$ \\
\hline & $\begin{array}{l}\text { De que forma vai funcionar a coleta? Haverá divulgação e orientação junto } \\
\text { aos condomínios e residências? }\end{array}$ \\
\hline \multirow{8}{*}{ Outros } & $\begin{array}{l}\text { Destinação do lixo, garantia de emprego aos catadores que trabalham nas } \\
\text { ruas, lucro que PMV tem? }\end{array}$ \\
\hline & $\begin{array}{l}\text { Apenas parabenizá-los. Que esse seja o primeiro passo para a educação e } \\
\text { conscientização do valor da vida, em todas as gerações. Boa sorte. }\end{array}$ \\
\hline & $\begin{array}{l}\text { Gostaria de saber se a PMV tem a intenção de ampliar esse projeto para as } \\
\text { secretarias, devido ao grande ao grande desperdício e mal uso dos } \\
\text { materiais. }\end{array}$ \\
\hline & $\begin{array}{l}\text { O Projeto. coleta. seletiva. que existe em outros Estados e alguns países são } \\
\text { excelentes para o meio ambiente. e qualidade. de vida da população. O } \\
\text { ponto falho em Vitória é a redução de } 6 \text { para } 4 \text { dias a coleta do lixo úmido. }\end{array}$ \\
\hline & $\begin{array}{l}\text { Por que as escolas, principalmente as da rede municipal não se integram ao } \\
\text { sistema? O que falta? Na minha modesta opinião, força de vontade dos } \\
\text { setores envolvidos como um todo. }\end{array}$ \\
\hline & O que a PMV tem feito para tornar realidade este projeto? \\
\hline & $\begin{array}{l}\text { Sou a favor da separação feita pela PMV e não por nós. Não tenho tempo } \\
\text { ou espaço para ficar separando. Sugiro que a PMV qualifique as pessoas } \\
\text { que fariam isto em uma área apropriada. }\end{array}$ \\
\hline & Onde posso colocar resíduos de óleo e embalagens de aerossol? \\
\hline
\end{tabular}

(*) Pergunta não inclusa no questionário escrito. 
Em termos gerais, os resultados apresentados no Quadro 21 reforçam a insuficiência das ações de divulgação do programa, já destacada na pesquisa qualitativa (Fase 3).

Quanto ao tema coleta, as citações das respostas dos questionários referem-se, em sua maioria, à preocupação com o funcionamento da operação da coleta seletiva, em parte devido à implantação da coleta seletiva porta a porta em alguns bairros do município, em curso na época da pesquisa. Este aspecto também está citado nos temas divulgação/informação e outros.

No tema divulgação/informação a maioria das citações apontaram para a necessidade de realizar ações de sensibilização, divulgação, informação e incentivo à participação na coleta seletiva. Os temas condomínios e triagem e destinação também expressam essa necessidade, sendo que o primeiro, num formato específico para estes núcleos habitacionais.

Em relação aos recipientes de coleta, observa-se a demanda dos participantes da pesquisa pelo aumento de PEV's instalados no município de Vitória-ES.

Fazendo-se uma análise conjunta das fases 3, 4 e 5, que tratam da participação social na coleta seletiva, obteve-se os seguintes resultados:

- o termo coleta seletiva é conhecido e associado aos resíduos sólidos, apesar de parte dos entrevistados não ter clareza do significado e da forma de funcionamento;

- a coleta seletiva é considerada importante. Existindo pré-disposição na maioria das pessoas em participar de programas de coleta seletiva;

- a coleta seletiva dos resíduos sólidos urbanos é considerada, em geral, como responsabilidade da prefeitura;

- a coleta seletiva é associada à economia de recursos financeiros pelo município e/ou a lucro;

- os entrevistados tem a noção de que muitos materiais presente nos resíduos sólidos poderiam ser reaproveitados; e,

- a maior parcela dos entrevistados entende como participar da coleta seletiva a ação de separar os resíduos sólidos que produz, existindo um grupo menor disposto a ajudar na divulgação e em trabalhos voluntários. 
Os resultados obtidos refletem as ações existentes no município de Vitória, desde 1998, em relação à implantação e desenvolvimento de programas de coleta seletiva. e também da veiculação na mídia nacional do tema.

Em termos de fatores de motivação para a participação social em programas de coleta seletiva, tem-se destacado:

- o ambiente e a qualidade de vida, associado à melhoria da limpeza urbana;

- redução de riscos para a população e para o pessoal que trabalha na limpeza urbana;

- a organização e adequação da estrutura operacional implantada para dar suporte ao programa; e,

- a existência de ações continuadas de divulgação, mobilização e informação.

Tais resultados, em parte, reforçam a sugestão de CRESPO (2002) quanto à utilização do elo da saúde, qualidade de vida e meio ambiente para sensibilizar a população para participar da coleta seletiva.

Destacam-se ainda a organização e a adequada operacionalização das ações, associadas à regularidade e qualidade dos serviços de coleta seletiva oferecidos, que devem conquistar a credibilidade da população.

A necessidade de ações continuadas de divulgação, mobilização e informação estaria associada à existência do grupo populacional cativo, em termos de participação social na coleta seletiva (Hipótese 2).

Os principais aspectos que impedem ou dificultam a participação da população, por sua vez, estão associados à ausência dos fatores de motivação supra listados, tendo sido citados ainda:

- a falta de divulgação dos resultados da coleta seletiva;

- a acomodação e o desinteresse da população;

- a cultura e o nível de instrução do povo brasileiro que, em geral, tem o hábito de jogar lixo no chão; e,

- o descrédito relativo a ações oriundas do poder público. 
O descrédito nas ações do poder público, por sua vez, estaria associado ao grupo populacional que não participa, em termos de participação social na coleta seletiva (Hipótese 2).

$\mathrm{Na}$ pesquisa constatou-se, também, que os meios de comunicação em geral representam uma importante fonte de informações e divulgação da coleta seletiva, junto à população.

Cabe acrescentar um padrão de comportamento que se verifica nas famílias brasileiras no qual, geralmente, um membro da família ou um empregado é o responsável pelo acondicionamento e a entrega dos resíduos sólidos, ali gerados, ao sistema público de coleta, ficando os demais totalmente ausentes e descompromissados com a questão. Este comportamento tende a se repetir em relação à coleta seletiva, sendo identificado ainda, como dificuldades para a adesão:

- a falta de espaço para armazenar os resíduos sólidos recicláveis;

- a necessidade de limpar previamente as embalagens para evitar problemas com insetos e odores desagradáveis, durante o armazenamento; e,

- o trabalho e a demora no acondicionamento, principalmente quando é realizado a redução de volume das embalagens.

Vencidas estas etapas é necessário entregar os resíduos sólidos recicláveis à coleta seletiva. Ocorrendo situações em que o material após separado acaba indo para a coleta regular, principalmente, no caso de coleta seletiva por meio de PEVs.

Verificou-se que a maioria das pessoas levam os resíduos sólidos recicláveis aos PEVs de carro ou bicicleta. Ter que caminhar até um PEV é sendo considerado, por muitas pessoas, como perda de tempo, constrangimento e/ou desconforto.

Em geral, a não participação na coleta seletiva estaria associada à falta de informação, estrutura e tempo.

A informação sobre a responsabilidade individual de cada cidadão, no processo de coleta seletiva, ainda, é pouco difundida e a maioria das pessoas participa de forma passiva, condicionada ao oferecimento de estrutura de coleta e seguindo as regras estabelecidas pelo poder público. 
Houve pouca associação entre os resíduos sólidos e agravos à saúde, o que talvez possa ser atribuído ao fato de que, no município de Vitória, exista coleta regular de resíduos sólidos diariamente, em todos bairros, e uma boa estrutura de limpeza urbana, havendo pouca ocorrência de pontos de acúmulo indevido de resíduos.

Com os resultados obtidos, foi possível verificar, também, a validade da Hipótese 2, onde se supõe que a população alvo de programas de coleta seletiva possa ser agrupada em grupo cativo, de participação eventual e que não participa, em especial nos DSCs obtidos a partir da pergunta 2, da pesquisa qualitativa (Fase3). 


\section{CONCLUSÕES E RECOMENDAÇÕES}

\subsection{Conclusões}

Atendendo aos objetivos traçados para o desenvolvimento da presente tese foram avaliados os aspectos operacionais e da participação da população em Programas de Coleta Seletiva de resíduos sólidos urbanos, tendo como estudo de caso o município de Vitória (ES). As conclusões decorrentes da análise dos resultados seguem apresentadas:

Considerando-se o objetivo de instituir grupo de indicadores de referência para o planejamento e a avaliação de desempenho de Programas de Coleta Seletiva, inicialmente, foram levantados os principais indicadores utilizados no Brasil com esta finalidade. Essa identificação resultou em um total de 25 indicadores.

Os 25 indicadores identificados, uma vez validados, mediante a utilização de testes estatísticos, resultaram no grupo de indicadores de referência que se buscava instituir, conforme apresentado:

\section{Cobertura de atendimento do programa (hab);}

2. Índice de Recuperação de Materiais Recicláveis - IRMR (\%);

3. Quantidade mensal coletada seletivamente (t/mês);

4. Custo de triagem $(\mathrm{R} \$ / \mathrm{t})$;

5. Quantidade de itens de materiais recicláveis comercializados (un); e,

6. Custo total do programa $(\mathrm{R} \$ / \mathrm{t})$.

O grupo de indicadores de referência obtido, envolvendo 6 indicadores, contempla os aspectos de custo, de escala, de operação e de participação da população. Depois de aplicado à série histórica de dados do município de Vitória, possibilitou constatar os pontos críticos do programa de coleta seletiva implantado e, que é possível representar os diversos aspectos operacionais envolvidos em Programas de Coleta Seletiva a partir de um grupo de indicadores, o que validou a Hipótese 1 proposta. 
Os principais pontos críticos identificados, no estudo de caso, do município de Vitória, referem-se a dificuldades para operação e ampliação do programa de coleta seletiva existente, nos moldes implantado, além da garantia da sua continuidade ao longo do tempo.

Tais pontos críticos mostraram-se consistentes com os fatores críticos de sucesso do programa de coleta seletiva da cidade de Ribeirão Preto (SP), identificados por CAMPOS (1994), em estudo realizado nesse município. Correspondem também, aos fatores limitantes observados nos programas municipais de coleta seletiva visitados, em operação, nos municípios de São Bernardo do Campo (SP), Florianópolis (SC), Porto Alegre (RS) e Santo André (SP).

As conclusões obtidas, face à avaliação dos aspectos operacionais de Programas de Coleta Seletiva de resíduos sólidos urbanos, são:

- A utilização dos indicadores resultantes da presente pesquisa, na avaliação do Programa de Coleta Seletiva implantado, no município de Vitória mostrou-se adequada e suficiente, possibilitando a identificação de informações importantes que embasaram a avaliação do andamento e dos resultados do referido Programa. A avaliação periódica de Programas de Coleta Seletiva, com o emprego de indicadores permite identificar os pontos fortes e os pontos críticos dos mesmos, o custo-benefício de sua implantação, a sustentabilidade e os entraves para sua continuidade, como também possibilita a correção da rota em tempo. Assim, os indicadores resultantes constituem-se em grupo que servirá para avaliação dos inúmeros Programas de Coleta Seletiva implantados no Brasil e em outros paises, quando contemplem as mesmas características, o que permitirá uma análise comparativa entre tais Programas.

- A realização periódica de ensaios de caracterização dos resíduos sólidos coletados, como informação complementar, propiciou a análise real dos resultados do programa implantado, sendo imprescindível para a modalidade coleta seletiva porta a porta;

- Os Programas de Coleta Seletiva devem considerar e contemplar as características da realidade local. È necessário estabelecer critérios específicos para o desenvolvimento de programas de coleta seletiva em áreas de diferentes 
densidades populacionais, uso de solo e classe sócio-econômica, por exemplo. A adoção de um modelo único de programa para situações diversas pode comprometer os resultados e gerar maiores custos operacionais;

- Os custos de coleta e transporte são significativos em programa de coleta seletiva, sendo importante identificar os grandes geradores de resíduos recicláveis como os condomínios, centros de compras, supermercados entre outros e atuar de forma específica sobre estes;

- A quantidade de materiais recicláveis recuperada pela coleta seletiva não aumenta proporcionalmente aos investimentos feitos e à ampliação da cobertura populacional do programa. Conforme observado na pesquisa, o aumento depende, além desses fatores, fundamentalmente da participação social. Sendo necessário, despertar e manter a motivação da população local em participar;

- A organização e estrutura da limpeza urbana refletem-se no desempenho da coleta seletiva, sendo pré-requisito a aprovação e a credibilidade da população envolvida quanto aos serviços básicos de limpeza urbana prestados;

- A informação, capacitação e motivação do pessoal direta e indiretamente envolvido com a implementação da coleta seletiva, contextualizando o papel de cada colaborador face aos objetivos traçados, é fator decisivo para o sucesso do Programa. Esta ação deve ser permanente, com divulgação periódica dos resultados alcançados, pois tem grande interface com a população alvo do programa;

- A existência de um grupo permanente de acompanhamento e avaliação da coleta seletiva, com participação dos vários setores envolvidos na questão, apresenta-se como uma eficiente alternativa para otimizar o gerenciamento do programa implantado;

- É necessário que exista, no âmbito do Sistema de Limpeza Urbana - SLU municipal, um técnico responsável ou equipe específica para gerenciar a coleta seletiva, além de estrutura de apoio administrativo e orçamento. Tais requisitos contribuem para a continuidade dos programas implantados, uma vez que conferem, à coleta seletiva, status de programa institucional permanente; 
- A ausência de política pública clara, objetiva e exeqüível para a interface da coleta seletiva com os catadores, compromete o desenvolvimento do programa de coleta seletiva;

- A implementação de programas de coleta seletiva bem planejados, operados e avaliados, resulta na sua maior sustentabilidade e duração, o que contribui para reduzir a quantidade de RSU a serem dispostos no ambiente e para a presevação dos recursos naturais (saúde ambiental); contribui para a melhoria das condições de trabalho das pessoas envolvidas com a coleta e triagem dos RSU (saúde ocupacional) e ainda gera recursos que desenvolvem atividades econômicas na localidade. Esses aspectos contribuem para a qualidade do ambiente e para a qualidade de vida; e,

- A utilização do enfoque do gerenciamento integrado de resíduos sólidos para o planejamento e implantação de programas de coleta seletiva traz melhores resultados que os enfoques de resgate de cidadania e estratégia de marketing, sendo fundamental considerar, envolver e integrar as demais políticas públicas setoriais (meio ambiente, educação, saúde, ação social, recursos humanos, planejamento urbano, ente outras) e a sociedade civil.

As conclusões referentes aos aspectos de participação da população em Programas de Coleta Seletiva de resíduos sólidos urbanos são apresentados na seqüência.

A partir de pesquisa qualitativa, foram identificados os fatores de motivação e os aspectos que impedem ou dificultam a participação social em Programas de Coleta Seletiva de resíduos sólidos urbanos. O que possibilitou concluir que os principais aspectos que impedem ou dificultam a participação da população na coleta seletiva estão associados à ausência dos fatores de motivação identificados.

Esses fatores de motivação estão consistentes com os estudos de CRESPO (2003), sobre o que os brasileiros pensam sobre meio ambiente, existindo o elo da saúde, qualidade de vida e meio ambiente.

Como informações de caráter complementar, realizou-se a pesquisa sobre o nível de informações do pessoal, direta e indiretamente, envolvido com a implementação dos programas de coleta seletiva do município de Vitória. 
Os resultados, ao contrário da expectativa inicial, permitem concluir que a maioria dos entrevistados (58,8\%) não participa da coleta seletiva ou participa apenas há menos de 6 meses, apesar de considerarem como suficientes às informações que recebem sobre coleta seletiva, que teriam condições de armazenar os resíduos recicláveis em suas residências por até uma semana e que não há dificuldade em realizar a separação dos resíduos sólidos para a reciclagem.

Na pesquisa, verificou-se a importância das campanhas de divulgação e a grande influência da mídia através da TV, jornais e revistas, quanto aos meios de obtenção de informações sobre coleta seletiva. Os maiores fatores de motivação, para o grupo pesquisado, são o meio ambiente (70,1\%); seguido do fator qualidade de vida e limpeza (66,4\%); educação (56,1\%). Apenas 15,9\% das respostas referiram-se às campanhas de divulgação, o que confirma a não efetividade das campanhas de divulgação quando implementadas de forma não integradas a outras ações.

De um modo geral, as conclusões obtidas referentes à participação social nos Programas de Coleta Seletiva do município de Vitória indicam que a população do município:

- Conhece o termo coleta seletiva e faz sua associação com os resíduos sólidos, apesar de parte das pessoas não ter a clareza do seu significado e não entender sua forma de funcionamento;

- Considera a coleta seletiva importante. Na maioria das pessoas consultadas, há pré-disposição para a participação da coleta seletiva;

- Em geral, considera a coleta seletiva dos resíduos sólidos urbanos como responsabilidade da prefeitura;

- Associa a coleta seletiva à economia de recursos financeiros pelo município e/ou a lucro;

- Tem noção de que muitos materiais presentes nos resíduos sólidos poderiam ser reaproveitados; e,

- Em sua grande maioria, entende como participação no Programa de Coleta Seletiva apenas a ação de separar os resíduos sólidos que produz. Há um grupo menor disposto a ajudar na divulgação e em trabalhos voluntários. 
Quanto aos aspectos da participação da população são:

- A existência da coleta seletiva é vista como algo benéfico pela população, destacado-se como fatores de motivação para participação o meio ambiente e a qualidade de vida, associado à melhoria da limpeza urbana.

- A participação voluntária da população na Coleta Seletiva é baixa, podendo aumentar a longo prazo. A implementação de mecanismos adicionais para condicionar a participação como legislação específica e incentivos econômicos, desde que não acarretem o aumento do consumo de descartáveis, pode acelerar este processo;

- A participação da população na coleta seletiva é decorrência da organização e adequação da infraestrutura implantadas para dar suporte ao programa e da existência de ações continuadas de divulgação, mobilização e informação.

- A participação efetiva da população (grupo cativo) na coleta seletiva aumenta gradativamente na medida do aumento do trabalho de mobilização da comunidade, podendo ocorrer mobilidade de pessoas entre os grupo de participação eventual e cativo em função da continuidade das ações.

- A participação continuada na coleta seletiva faz o cidadão rever seus hábitos, mudar o comportamento e aumentar a consciência quanto a sua responsabilidade na destinação dos resíduos sólidos que gera.

- A insuficiência e a descontinuidade das ações de divulgação e mobilização é destacada dentre os principais aspectos que impedem ou dificultam a participação da população;

- A existência de um canal de comunicação com a população, com registro formal de dados, bem como a realização periódica de pesquisas de opinião oferece informações valiosas para realização de ajustes necessários aos programas de coleta seletiva.

- Nos resultados obtidos na pesquisa, ficou pouco evidenciada a associação da atividade dos catadores autônomos de materiais recicláveis com a coleta seletiva e a geração de trabalho e renda. Atribuiu-se o fato à existência da visão de que a atividade de catador não seja uma profissão e sim uma busca de sobrevivência para pessoas que estão à margem da sociedade, não havendo organização e, portanto, não estando associado à coleta seletiva. 
- Para o grupo populacional, avaliado a partir da pesquisa qualitativa, a não participação na coleta seletiva estaria associada à falta de informação, estrutura e tempo para participar e ao descrédito relativo a ações oriundas do poder público.

Esta etapa permitiu, ainda, verificar a adequação da classificação da população alvo de programas de coleta seletiva em 3 grupos: cativo, de participação eventual e que não participa, o que confirma a hipótese 2.

Como proposição de diretrizes para subsidiar políticas públicas em programas de coleta seletiva a pesquisa permite apontar aspectos como:

- Rever o modelo atual de gestão de RSU, passando a tratar a coleta seletiva de forma intersetorial estimulando a ação coordenada entre as entidades da sociedade civil organizadas, a indústria e o poder público;

- Criar rotinas para o registro de informações e apuração dos dados sobre o desenvolvimento dos programas de coleta seletiva, que devem ser periodicamente divulgados na forma de indicadores;

- Divulgar os indicadores em linguagem acessível que permita à comunidade interessada entender, questionar e/ou responder às informações disponibilizadas pela entidade gestora da coleta seletiva;

- Criar mecanismos de incentivo a pesquisas sobre novas tecnologias para reutilização e reciclagem de resíduos sólidos;

- Considerar, nos estudos para o planejamento de programas de coleta seletiva, alternativas para a recuperação também da parcela de matéria orgânica presente nos resíduos sólidos urbanos. A recuperação da matéria orgânica pode ser tratada como etapa subseqüente à ação referente aos resíduos recicláveis;

- Criar e implementar as políticas: nacional e estaduais de resíduos sólidos com destaque e incentivo à adoção dos princípios da minimização dos resíduos, envolvendo as etapas de redução, reutilização e reciclagem, o que traria reflexos positivos sobre a consolidação dos programas de coleta seletiva no país;

- Dar prioridade nos financiamentos públicos à empreendimentos que utilizam matéria prima oriunda dos programas de coleta seletiva;

- Incentivar a reciclagem através de legislação tributária favorável, em nível federal, estadual e municipal; 
- Incentivar, cada vez mais, a coleta seletiva como contribuição para a solução da problemática dos resíduos sólidos, a qual causa vários problemas ao ambiente e à saúde pública. A integração do tema às ações de educação em saúde e controle de vetores seria uma alternativa viável e de baixo custo;

- Investir parte dos recursos destinados ao programa na sensibilização de agentes formadores de opinião e disseminadores de informação, como repórteres e conselhos editoriais da mídia impressa, comunicadores de rádio e TV e professores. Tais agentes poderiam utilizar os indicadores para divulgar e avaliar os de programas de coleta seletiva. A sensibilização e obtenção de apoio da mídia quanto à importância da utilização de indicadores, na comparação de programas de coleta seletiva, requer tempo, sendo o apoio desse canal de comunicação fundamental para a consolidação da coleta seletiva no país;

Acredita-se que os resultados obtidos poderão ter grande aplicação no gerenciamento, ampliação e melhoria de Programas de Coleta Seletiva em todo país.

\subsection{Recomendações}

Visando dar continuidade aos estudos sobre o gerenciamento de programas de Programas de Coleta Seletiva, face aos resultados obtidos, recomenda-se:

- Desenvolver novos estudos de caso aplicando o grupo de Indicadores de Referência para o planejamento e a avaliação de desempenho de Programas de Coleta Seletiva instituído, para outras condições de contorno;

- Desenvolver índices para avaliação comparativa de qualidade entre Programas de Coleta Seletiva, a partir do agrupamento de indicadores, partindo do grupo de Indicadores de Referência resultante da presente tese;

- Desenvolver metodologias para amostragem e caracterização gravimétrica de resíduos sólidos oriundos de regiões com coleta seletiva porta a porta, considerando as diversas interferências existentes como a coleta alternada de resíduos recicláveis inorgânicos e coleta regular e a ação de catadores; e,

- Aprofundar estudos sobre os fatores que influenciam os resultados operacionais e de participação social dos programas de coleta seletiva de RSU. 


\section{REFERÊNCIAS}

1. ABNT, Associação Brasileira de Normas Técnicas. NBR 10.004. Resíduos Sólidos - Classificação. 2004.

2. Aguiar A. As parcerias em programas de coleta seletiva de resíduos sólidos domésticos. São Paulo; 1999. [Dissertação de mestrado - Faculdade de Saúde Pública da USP].

3. Aguiar A, Philippi Jr A. O papel das parcerias na operação de programas de coleta seletiva In: IX Simpósio Luso-Brasileiro de Engenharia Sanitária e Ambiental; 2000 abr 9-14; Salvador (BA). s.1.: ABES; 2000. p. 1619-28.

4. Aguiar A, Philippi Jr A. A estruturação de programas de coleta seletiva. In: $\mathbf{2 1}^{\mathbf{0}}$ Congresso Brasileiro de Engenharia Sanitária e Ambiental; 2001 set 16-21; João Pessoa (PB). s.1.: ABES; 2001.

5. Atkisson A. Desenvolvimento de Indicadores de Comunidades Sustentáveis Lições do Seattle Sustentável. [on line]. Brasil: MMA; 1996. Disponível em: <URL: http://www.bsi.com.br/unilivre/centro> [2003 nov 28].

6. Azevedo M, Heller L, Shalch V. Avaliação do Potencial de Risco para a Saúde da Disposição Inadequada dos Resíduos Sólidos In: $\mathbf{2 1}^{\circ}$ Congresso Brasileiro de Engenharia Sanitária e Ambiental; 2001 set 16-21; João Pessoa (PB). s.1.: ABES; 2001.

7. Batista FRM. Caracterização física e comercial do lixo urbano de Vitória ES, em função da classe social geradora. Vitória; 2001. [Dissertação de Mestrado - Universidade Federal do Espírito Santo].

8. Besserman S. Indicadores. In: Trigueiro A, coordenador. Meio Ambiente no Século 21. Rio de Janeiro: Sextante; 2003. p. 90-105.

9. Calderoni, Sabetai. Os Bilhões Perdidos no Lixo. 3 ed. São Paulo: Humanitas, 1999.

10. Campos R. Proposta de sistematização e reavaliação do processo de gerenciamento de serviços de coleta seletiva de resíduos sólidosdomiciliares. São Carlos (SP); 1994. [Dissertação de mestrado - Escola de Engenharia de São Carlos da USP]. 
11. CEPIS. Manual de minimizacion de resíduos em la industria de acabados de metales. [on line]. Peru: CEPIS/OPS; 1997. Disponível em: <URL: http://www.cepis.org.pe/eswww/fulltext/gtz/manmire/mricap02.html> [2003 dez 09].

12. CEMPRE. Guia de Coleta Seletiva de Lixo. São Paulo: CEMPRE; 1999.

13. CEMPRE. Pesquisa CICLOSOFT. [on line]. Brasil: CEMPRE; 2002. Disponível em: <URL: http://www.cempre.com.br> [2003 nov 28].

14. CETESB. Resíduos Sólidos Industriais. São Paulo: CETESB; 1993.

15. [CNUMAD] Conferência das Nações Unidas Sobre o Meio ambiente e Desenvolvimento; 1992 jun 3-14; Rio de Janeiro (BR). Brasília: Edições Técnicas; 1997.

16. Crespo S. Opnião Pública. In: Trigueiro A, coordenador. Meio Ambiente no Século 21. Rio de Janeiro: Sextante; 2003. p. 58-73.

17. Costa e Silva EC, Prasad S, Leite VD. Lixo X Sobrevivência: Uma Análise Socioeconômica e Ambiental do Forno do Lixo da cidade de Natal - RN. In: $\mathbf{2 1}^{\mathbf{0}}$ Congresso Brasileiro de Engenharia Sanitária e Ambiental; 2001 set 16-21; João Pessoa (PB). s.1.: ABES; 2001.

18. Eingenheer EM, organizador. Coleta seletiva de lixo: experiências brasileiras N 3. Rio de Janeiro: UFF/CIRS; 1999.

19. Franca LP. Indicadores Ambientais Urbanos/Manual Geo Cidades. Brasília: MMA/ Consórcio Parceria 21; 2001.

20. Gil AC. Como elaborar projetos de pesquisa. 3. ed. São Paulo : Atlas; 1996.

21. Grimberg E, organizadora. Blauth P, organizadora. Coleta Seletiva: Reciclando materiais, reciclando valores. São Paulo: UNICEF/Polis; 1998. p. 7-72.

22. [IBGE] Fundação IBGE. Pesquisa Nacional de Saneamento Básico. Rio de Janeiro, Fundação IBGE, 2002.

23. ISER. Agenda 21 - perguntas e respostas. Rio de Janeiro: ISER; 1996.

24. IPT/CEMPRE. Lixo Municipal: manual de gerenciamento integrado. 1 ed. São Paulo: IPT/CEMPRE; 1995.

25. Lefèvre F, Lefèvre AMC. O Discurso do sujeito coletivo: teoria e prática. São Paulo; 2002.[Apostila do Curso de Verão Pesquisa Qualitativa: Novas 
Metodologias de Análise de Discurso (PQN) - Faculdade de Saúde Pública da USP].

26. Lima CR. Gerenciamento Integrado de resíduos sólidos [apresentado ao curso de capacitação em limpeza pública para profissionais de prefeituras; 2002 set 20; Vitória (ES), Brasil].

27. Massukato LM e Zanta VM. Método Delphi - Uma Ferramenta de Apoio para Gestão dos Resíduos Sólidos Urbanos. In: XI Simpósio Luso-Brasileiro de Engenharia Sanitária e Ambiental; 2004 mar 9 a abr.2; Natal (RN). s.1.: ABES; 2004. p. .

28. Milanez B, Teixeira BAN. Contextualização de princípios de sustentabilidade para a gestão de resíduos sólidos urbanos. In: $2^{\circ}$ Congresso Brasileiro de Engenharia Sanitária e Ambiental; 2001 set 16-21; João Pessoa (PB). s.l.: ABES; 2001. p 1-11.

29. [MMA] Ministério do Meio Ambiente. Manual Geo Cidades. Brasília: MMA/ Consórcio Parceria 21; 2002.

30. [MC] Ministério das Cidades. SNIS. Brasília: MC; 2003.

31. Monteiro JHP, Figueiredo CEM, Magalhães AF, Melo MAF, Brito JCX, Almeida TPF , Mansur GL. Manual de Gerenciamento Integrado de resíduos sólidos. Rio de Janeiro: IBAM, 2001.

32. Nunesmaia MFS. Como mensurar a participação de uma população/comunidade num programa de coleta seletiva In: IX Simpósio Luso-Brasileiro de Engenharia Sanitária e Ambiental; 1995 abr 9-14. s.1.: ABES; 1995.

33. Pereira MG. Epidemiologia: teoria e prática. Rio de Janeiro: Guanabara Koogan S.A., 1995. p. 49-63.

34. Pilon AF. Fundamentos da educação ambiental: aspectos conceituais e modelos teóricos. São Paulo: FSP, 1998.

35. PNMA. Agenda 21 Global. [on line]. Brasil: MMA; 1993. Disponível em: <URL: http://www.mma.gov.br [2003 nov 28].

36. Portilho F. Limites e Possibilidades do Consumo Sustentável [Apresentado no Programa de Comunicação Ambiental da Companhia Siderúrgica de Tubarão; 2004 jul 08; Vitória (ES), Brasil]. 
37. Silva MMP, Leite VD. Diagnóstico Ambiental realizado segundo a percepção de educadoras do ensino fundamental de duas escolas do ensino fundamental da Rede Pública Municipal de Campina Grande - PB. In: $\mathbf{2 1}^{\circ}$ Congresso Brasileiro de Engenharia Sanitária e Ambiental; 2001 set 16-21; João Pessoa (PB). s.1.: ABES; 2001. p 1-6.

38. [SEMURB] Secretaria municipal de Serviços de Vitória. Programa Vitória cidade limpa. Vitória (ES); 2000. (SEMURB/ TDR - Relatório Técnico).

39. [SEMMAM] Secretaria municipal de Meio Ambiente. Projeto de Ampliação e Modernização da coleta seletiva. Vitória (ES); 2002. (SEMMAM/SEMURB/SUB - Programa Vitória Reduz e Recicla).

40. [SEDU] Secretaria de Desenvolvimento Urbano. Avaliação Técnico-Econômica e Social de sistemas de coleta seletiva de resíduos sólidos urbanos no Brasil. Brasília: SEDU; 2002.

41. SPSS: Statistical Package for the Social Sciences [programa de computador]. versão 8.0. Chicago (Illinois). Disponível em: <URL: http://www.spss.com> [2003 abr 8].

42. Thiesen MP. Metodologias de Minimização aplicadas no Gerenciamento de Resíduos. In: $2^{\circ}$ Congresso Brasileiro de Engenharia Sanitária e Ambiental; 2001 set 16-21; João Pessoa (PB). s.1.: ABES; 2001.

43. Villela SH et al. Validação Social de Políticas de Resíduos Sólidos Urbanos. In: $21^{\circ}$ Congresso Brasileiro de Engenharia Sanitária e Ambiental; 2001 set 1621; João Pessoa (PB). s.1.: ABES; 2001.

\section{BIBLIOGRAFIA COMPLEMENTAR}

1. Bailão CAG, Passarelli SH, Gripp WG, Conceição MB. Santo André: uma nova gestão para os resíduos sólidos In: $\mathbf{2 1}^{\circ}$ Congresso Brasileiro de Engenharia Sanitária e Ambiental; 2001 set 16-21; João Pessoa (PB). s.1.: ABES; 2001.

2. Barciote ML. Coleta seletiva e minimização de resíduos urbanos: uma abordagem integradora. São Paulo; 1994. [Tese de Doutorado - Faculdade de Saúde Pública da USP]. 
3. Barreto EMS. Estudo das características físico-química dos resíduos sólidos do setor comercial da cidade de Vitória-ES, visando subsidiar a implantação de uma coleta diferenciada. Vitória; 1999. [Dissertação de Mestrado Universidade Federal do Espírito Santo].

4. Dalla CFM. Indicadores para avaliação de desempenho ambiental na cafeicultura. Vitória; 2003. [Dissertação de Mestrado - Universidade Federal do Espírito Santo].

5. Eingenheer EM, organizador. Coleta seletiva de lixo: experiências brasileiras $\mathbf{N}^{\circ}$ 1. Rio de Janeiro: UFF/CIRS; 1993.

6. Eingenheer EM, organizador. Coleta seletiva de lixo: experiências brasileiras $\mathbf{N}^{\circ}$ 2. Rio de Janeiro: UFF/CIRS; 1998.

7. Fuzaro JA. Coleta seletiva para prefeituras. São Paulo: Secretaria do Meio Ambiente. CETESB; 1998.

8. Henriques VM. Estudo da composição gravimétrica e físico-química dos resíduos sólidos domiciliares do município de Vitória-ES. Vitória; 1999. [Dissertação de Mestrado - Universidade Federal do Espírito Santo].

9. [IBGE] Fundação IBGE. Censo Populacional. Rio de Janeiro, Fundação IBGE, 2002.

10. Laignier ITR. Caracterização gravimétrica e comercial dos resíduos sólidos urbanos recolhidos em postos de entrega voluntária do Sistema de Coleta Seletiva da Prefeitura Municipal de Vitória-ES. Vitória; 2001. [Dissertação de Mestrado - Universidade Federal do Espírito Santo].

11. Reidler NMVL. Resíduos gerados por pilhas e bateriais usadas: uma avaliação da situação brasileira 1999-2001. São Paulo; 2002. [Dissertação de mestrado - Faculdade de Saúde Pública da USP].

12. Reinfeld NV. Sistemas de reciclagem comunitária. São Paulo: Makron Books. 1994. 


\section{Anexo 1.}

Principais Indicadores utilizados para o planejamento e a avaliação de coleta seletiva no Brasil 


\section{Principais Indicadores utilizados para o planejamento e a avaliação de coleta seletiva no Brasil}

\section{Indicadores Gerais}

1. Cobertura de atendimento do programa

- Definição: expressa a parcela da população que é atendida pelo programa de coleta seletiva no município.

- Forma de apuração: quociente entre a somatória da população dos bairros ou regiões atendidos pelo programa de coleta seletiva e a população total do município x 100 .

- Representação: percentual

2. Índice de recuperação de materiais recicláveis

- Definição: expressa a quantidade de materiais recicláveis que deixaram de ser enviados à destinação final por terem sido separados pelo processo da coleta seletiva.

- Forma de apuração:

IRMR = (quantidade MR coletada - quantidade de rejeito $) \times 100$ (quantidade total de RSCD coletada + quantidade MR coletada )

onde:

$\mathrm{MR}=$ Materiais recicláveis

RSDC $=$ Resíduos sólidos domiciliares e comerciais

Rejeito $=$ matéria orgânica e outros materais impróprios para recuperação

- Representação: percentual

3. Custo unitário mensal da coleta e transporte

- Definição: expressa a relação entre o custo de coleta e transporte e o total de materiais recicláveis coletados no mesmo período

- Forma de apuração: quociente entre a somatória dos custos de veículos, incluindo insumos e manutenção, e pessoal envolvidos na coleta e transporte, durante um mês, e o total de materiais recicláveis coletados no mesmo período.

- Representação: $\mathrm{R} \$ / \mathrm{t}$ 
4. Custo unitário de triagem

- Definição: expressa a relação entre o custo de triagem e o total de materiais recicláveis triados no mesmo período

- Forma de apuração: quociente entre a somatória dos custos de pessoal, materiais, equipamentos e insumos e o total de materiais recicláveis triados no mesmo período.

- Representação: R\$/t

5. Custo unitário total da coleta seletiva

- Definição: expressa a relação entre o custos de coleta, transporte, triagem e destinação de materiais recicláveis e rejeitos, descontados dos ganhos de receita e economia de destinação final, e o total de materiais recicláveis coletados no mesmo período

- Forma de apuração:

Custo do Progr CSPP $=\{[$ (custo unit. coleta , transporte e triagem do MR $)+$ Custo de transbordo, transporte e destinacão final do rejeito ] - [receita da venda de MR + Economia de transbordo, transporte e destinacão final do MR recuperado ] / / total de MR coletado

onde:

$\mathrm{MR}=$ material reciclável

- Representação: $\mathrm{R} \$ / \mathrm{t}$

6. Eficiência de mão-de-obra de triagem

- Definição: expressa a média do rendimento horário da mão-de-obra por tonelada de materiais recicláveis processada

- Forma de apuração: quociente entre o total de materiais recicláveis triados e o tempo gasto para a sua triagem.

- Representação: t trabalhada/hora

7. Investimento per capita anual no programa

- Definição: expressa o investimento per capita anual feito em infra-estrutura e pessoal em função da população atendida.

- Forma de apuração: quociente entre a somatória dos investimentos feitos em infra-estrutura e pessoal do programa de coleta seletiva ao longo de um ano e a parcela da população atendida.

- Representação: R\$/hab/ano 
8. Percentual mensal de reclamações/ não conformidades

- Definição: expressa a relação entre $\mathrm{o} \mathrm{n}^{\circ}$ de reclamações sobre $\mathrm{o}$ programa de coleta seletiva e o ${ }^{\circ}$ total de reclamações sobre o sistema de limpeza pública feita pelos usuários

- Forma de apuração: quociente entre a somatória de reclamações/ não conformidades relativa ao serviço de coleta seletiva, recebidas durante o mês pela Central de Atendimento da população, e a somatória das reclamações/ não conformidades relativas ao sistema de limpeza pública no mesmo período.

- Representação: percentual

9. Despesa com marketing e educação

- Definição: expressa as despesas percapita anuais do programa com marketing e educação

- Forma de apuração: quociente entre a somatória das despesas para a coleta seletiva e a parcela da população atendida, no período de um ano.

- Representação: R\$/hab/ano

10. Freqüência média da coleta

- Definição: expressa o número de coletas realizadas no período de uma semana

- Forma de apuração: somatória do número de coletas realizadas no período de uma semana, no mesmo local.

- Representação: $n^{\circ}$ de coletas/semana

11. Percentual de resíduos orgânicos nos resíduos da coleta seletiva

- Definição: expressa a parcela de resíduos orgânicos presente nos resíduos da coleta seletiva

- Forma de apuração: a partir de um ensaio de caracterização fisica dos resíduos da coleta seletiva, para uma amostra de peso conhecido, seria o quociente entre o peso da parcela de orgânicos e o peso total da amostra x 100.

- Representação: percentual

12. Percentual de resíduos recicláveis presentes no lixo da coleta regular

- Definição: expressa a parcela de resíduos recicláveis presente no lixo da coleta regular 
- Forma de apuração: a partir de um ensaio de caracterização física do lixo da coleta regular, para uma amostra de peso conhecido, seria o quociente entre o peso da parcela de resíduos recicláveis e o peso total da amostra x 100 .

- Representação: percentual

13. Densidade de coleta

- Definição: expressa a quantidade de resíduos sólidos coletados por hora de operação da coleta

- Forma de apuração: quociente entre o total de resíduos sólidos coletados e o tempo gasto para a sua coleta.

- Representação: $\mathrm{t} / \mathrm{h}$

14. Eficiência de coleta seletiva

- Definição: expressa a quantidade de resíduos recicláveis coletados por hora e por $\mathrm{Km}$ rodado da coleta seletiva

- Forma de apuração: quociente entre o total de resíduos recicláveis coletados, o tempo gasto e o percurso percorrido para sua coleta.

- Representação: $\mathrm{t} / \mathrm{h} / \mathrm{km}$

15. Quantidade mensal coletada seletivamente

- Definição: expressa a quantidade de resíduos recicláveis coletados seletivamente no mês

- Forma de apuração: somatória das quantidades de resíduos recicláveis coletados seletivamente, no período de um mês.

- Representação: $\mathrm{t} /$ mês

16. Quantidade de itens de materiais recicláveis comercializado

- Definição: expressa a quantidade de itens de materiais recicláveis com mercado no programa de coleta seletiva

- Forma de apuração: somatória dos itens de materiais recicláveis comercializados pelo programa de coleta seletiva.

- Representação: unidade

17. Preço médio de comercialização do "mix" de materiais recicláveis

- Definição: expressa a média dos preços, por tonelada, praticados na comercialização dos diversos materiais recicláveis recuperados. 
- Forma de apuração: quociente entre a somatória dos preços por tonelada praticados na comercialização dos diversos materiais recicláveis e a quantidade de itens comercializados.

- Representação: R $\$ / t$

18. Receita apurada em vendas

- Definição: expressa a receita arrecadada com a venda dos materiais recicláveis no mês

- Forma de apuração: somatória das receitas arrecadadas com a venda dos diversos materiais recicláveis no período de um mês.

- Representação: R\$

19. Relação Receita/ Despesa

- Definição: expressa a relação entre a receita apurada em vendas dos recicláveis e as despesas do programa

- Forma de apuração: quociente entre a receita apurada em vendas e o custo total da coleta seletiva no mesmo período.

- Representação: número puro

\section{Indicadores Específicos}

\section{A - Coleta Seletiva por PEV's :}

20. Quantidade de PEV's instalados

- Definição: expressa o do total de PEV's instalados

- Forma de apuração: somatória dos PEV's instalados.

- Representação: unidade

21. Quantidade média de recicláveis por PEV

- Definição: expressa a quantidade média, em peso, de recicláveis coletados por PEV

- Forma de apuração: quociente entre a somatória entre a quantidade de recicláveis coletados e o número de PEV's instalados no mesmo período de tempo.

- Representação: t/PEV

22. Percentual mensal de vandalismo em PEV's 
- Definição: expressa o $n^{\circ}$ de PEV's danificados em relação ao total de PEV's instalados

- Forma de apuração: quociente entre o número de PEV's danificados e o total de PEV's instalados, no período de um mês.

- Representação: percentual

B- Coleta Seletiva Autônoma - Organização de Trabalhadores Autônomos :

23. Quantidade de Catadores envolvidos

- Definição: expressa o total de catadores trabalhando na organização, no mês estudado

- Forma de apuração: somatória dos catadores que trabalharam na organização no período de um mês.

- Representação: unidade

24. Renda média mensal

- Definição: expressa o ganho mensal por catador que trabalha na organização

- Forma de apuração: quociente entre a somatória dos valores pagos aos catadores e a quantidade de catadores envolvidos na organização, no período de um mês.

- Representação: R\$/catador

25. Percentual de rotatividade de catadores

- Definição: expressa a variação em percentual entre o total de catadores trabalhando na organização no mês e a média de catadores que trabalharam na organização nos últimos seis meses

- Forma de apuração:

$\%$ de rotatividade $=\left[\frac{\text { (quantidade coletores envolvidos - número médio de catadores) } \mathrm{x} 100}{\text { (número médio de catadores) }}\right]$

- Representação: percentual 
Anexo 02.

Pesquisa Quantitativa (Fase 1)

Análise Descritiva - Indicadores de Coleta Seletiva 


\section{Questionário}

\section{Pesquisa sobre Indicadores de Coleta Seletiva de Lixo ( Pré-Teste)}

\section{I - Perfil / Identificação:}

Nome:

.Formação:

.Especialidade/ Experiência profissional relacionada a Programas de Coleta Seletiva:

.Órgão/Entidade/Cargo:

Tel. $(0 \mathrm{xx})$

$$
\operatorname{Fax}(0 \mathrm{xx})
$$

II - Avaliação de Indicadores de Coleta Seletiva de Lixo:

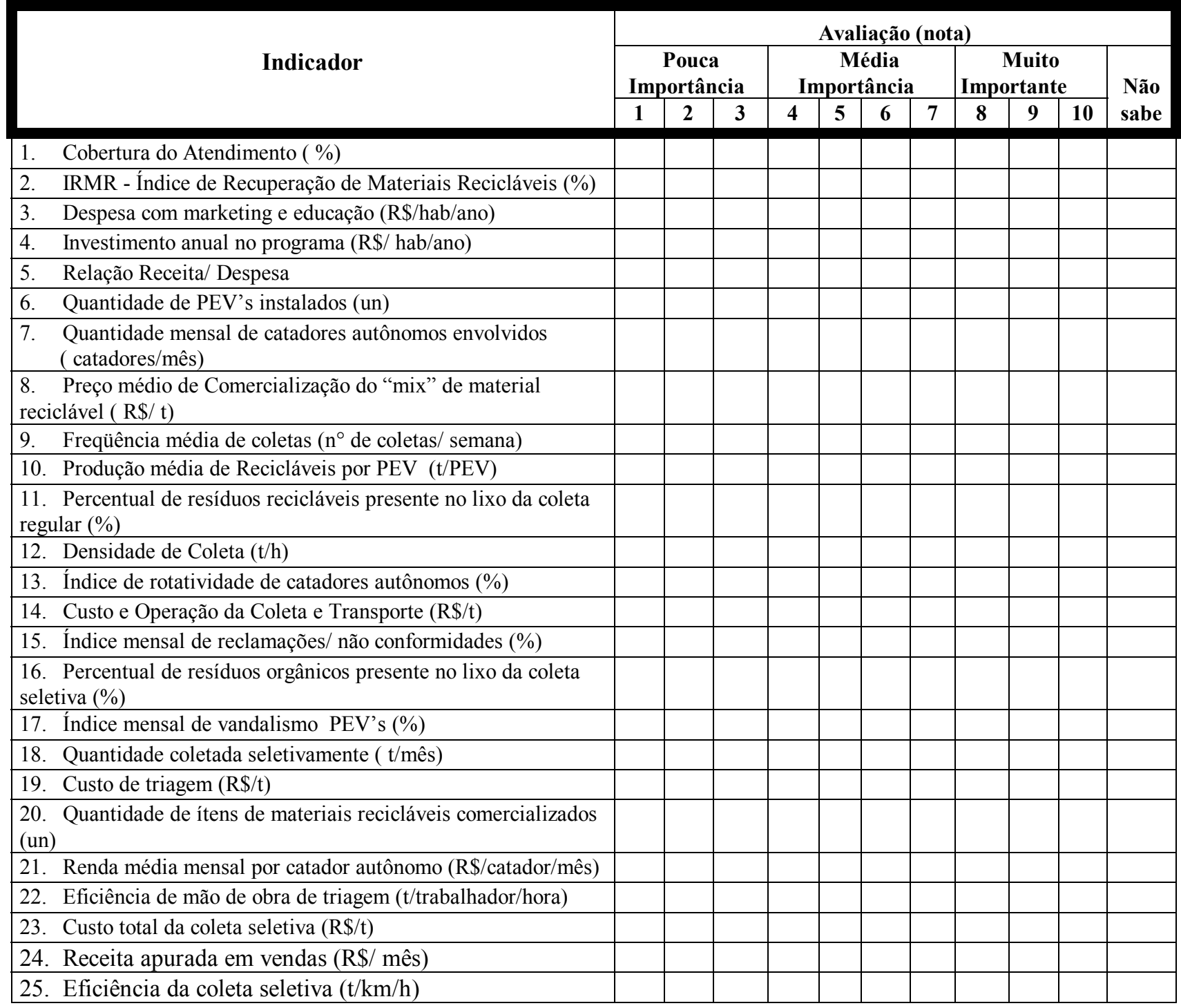

Nota: $\quad$ PEV - Posto de Entrega Voluntária

$\mathrm{IRMR}=$ Quantidade Coletada seletivamente - Quantidade de rejeitos na triagem $x 100$ Quantidade coletada seletivamente + Quantidade coletada de lixo "comum" 
Resultado - Pré-Teste

Data: 28 a 31 de outubro de 2002

\section{Amostra:}

01 especialista ( A )

Secretária de Serviços da Prefeitura de Vitória

01 profissional ( B )

Departamento de Limpeza Pública de Vitória

\section{Resultados:}

(A)

- Considerou o questionário bem elaborado;

- Quanto a listagem de indicadores levantou dúvidas para os parâmetros:

- 1. Cobertura de Atendimento ( $\%)$

considerou que a forma de cálculo e a unidade utilizada não seria correta, em especial quando se tratar da modalidade de coleta seletiva por postos de entrega voluntária que sob seu ponto de vista deve ser trabalhada em termos de zona de influência. Assim, o cálculo deveria ser feito considerando área e densidade populacional para cada um dos equipamentos e após adicionados em uma somatória.

- $\quad$ 1. Eficiência da Coleta Seletiva $(\mathrm{t} / \mathrm{km} / \mathrm{h})$

considerou que a forma de cálculo e a unidade utilizada não seria correta para expressar eficiência, e também que não teria grande aplicação.

(B)

- Sugeriu maior detalhamento do ítem I - Identificação do Informante, em especial no quesito " órgão/entidade/cargo" ;

- Sugeriu incluir também, no próprio corpo do questionário, instruções adicionais sobre o seu preenchimento;

- Não houve questionamento sobre a listagem de indicadores; 


\section{Análise Descritiva - Instrumento de pesquisa aplicado: \\ QUESTIONÁRIO \\ Pesquisa sobre Indicadores de Coleta Seletiva de Lixo}

Como etapa metodológica do desenvolvimento de trabalho de pesquisa científica busca-se validar um grupo de indicadores de coleta seletiva, dentre vários que levantados a partir de revisão bibliográfica sobre o tema.

Assim, foi elaborado o questionário a seguir onde são apresentados 25 indicadores com suas respectivas unidades de medida, aos quais deverão ser atribuídas notas variando de 1 a 10 por profissionais e especialistas que atuam direta ou indiretamente com a questão da coleta seletiva.

Para responder o questionário a seguir, basta preencher com seus dados pessoais a parte de identificação do entrevistado e marcar X na nota atribuída a cada um dos 25 indicadores apresentados.

Em caso de dúvidas ou desconhecimento do indicador assinalar com X na opção "não sabe".

\section{I -Identificação do informante:}

.Nome:

.Formação acadêmica:

( ) graduação ( ) especialização ( ) mestrado ( ) doutorado

.Curso Superior:

.Instituição/ Empresa em que atua:

.Cargo ou função:

. Tel. (0xx)

$\operatorname{Fax}(0 \times x)$

. Possui experiência profissional relacionada a Programas de Coleta Seletiva:

( ) $\operatorname{sim}$ ( ) não

. Caso sim, período de Experiência com Programas de Coleta Seletiva:

até 6 meses ( ) de 6 meses à 1 ano ( )

de 1 a $2 \operatorname{anos}($ ) acima de 2 anos ( ) 
Anexo 2

\section{II - Avaliação de Indicadores de Coleta Seletiva de Lixo:}

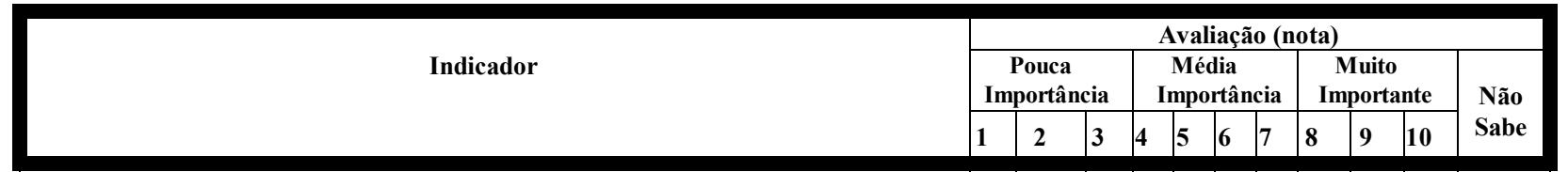

1. Cobertura do Atendimento ( hab)
(expressa a parcela da população que é atendida pelo programa de coleta seletiva )

2. IRMR - Índice de Recuperação de Materiais Recicláveis (\%)*

(expressa a quantidade de materiais reaproveitados pelas indústrias de reprocessamento)

3. Despesa com marketing e educação (R\$/hab/ano)

(expressa as despesas anuais do programa com marketing e educação)

4. Investimento per capita anual no programa (R\$/ hab/ano)

( expressa o investimento per capita anual feito em infra-estrutura e pessoal )

5. Relação Receita/Despesa (expressa a relação entre a receita da comercialização dos recicláveis e as despesas do programa)

6. Quantidade de PEV's** instalados (un)

( expressa o tamanho do projeto a partir do total de PEV's instalados)

7. Quantidade mensal de catadores autônomos envolvidos na organização (catadores/mês) (expressa o total de catadores trabalhando na organização no mês)

8. Preço médio de comercialização do "mix" de material reciclável $(\mathrm{R} \$ / \mathrm{t})$

( expressa a média dos preços praticados na comercialização dos diversos materiais recicláveis por tonelada )

9. Freqüência média de coletas $\left(\mathrm{n}^{\circ}\right.$ de coletas/ semana)

( expressa a relação entre os dias de coleta em relação ao total de dias da semana)

10. Produção média de Recicláveis por PEV (t/PEV)

( expressa a quantidade média em peso de recicláveis coletados por PEV)

11. Percentual de resíduos recicláveis no lixo da coleta regular $(\%)$

( expressa a parcela de recicláveis presente no lixo da coleta regular)

12. Densidade de Coleta $(t / h)$

( expressa a quantidade de recicláveis coletados por hora de operação da coleta)

13. Percentual de rotatividade de catadores autônomos $(\%) * * *$

( expressa a relação entre o total de catadores trabalhando na organização no mês e a média de catadores que trabalharam na organização nos últimos seis meses)

14. Custo mensal de Operação da Coleta e Transporte $(\mathrm{R} \$ \mathbf{t})$

( expressa a relação entre o custo de coleta e transporte e o total de recicláveis coletados no mesmo período)

15. Percentual mensal de reclamações/não conformidades (\%)

( expressa a relação entre o $\mathrm{n}^{\circ}$ de reclamações sobre o programa de coleta seletiva e o $\mathrm{n}^{\circ}$ total de reclamações sobre o sistema de limpeza pública feita pelos usuários)

16. Percentual de resíduos orgânicos no lixo da coleta seletiva (\%)

( expressa a parcela de orgânicos presente no lixo da coleta seletiva)

17. Índice mensal de vandalismo PEV's (\%)

( expressa o n ${ }^{\circ}$ de PEV's danificados em relação ao total de PEV's instalados)

18. Quantidade mensal coletada seletivamente ( $t / \mathbf{m e ̂ s})$

( expressa a quantidade de recicláveis coletados seletivamente no mês )

19. Custo de triagem (R\$/t) ( expressa a relação entre o custo de triagem e o total de recicláveis processados no mesmo período)

20. Quantidade de itens de materiais recicláveis comercializados (un)

( expressa a quantidade de itens de recicláveis com mercado no programa)

21. Renda média mensal por catador autônomo (R\$/catador/mês) $* * *$

( expressa o ganho mensal por catador que trabalha na organização)

22. Eficiência de mão de obra de triagem (t/trabalhador/hora)

( expressa a média do rendimento horário da mão de obra por tonelada processada)

23. Custo total da coleta seletiva (R\$/t) ( expressa a relação entre o custo de coleta, transporte e triagem e o total de recicláveis coletados no mesmo período)

24. Receita apurada em vendas ( $R$ \$ $/$ mês)

( expressa a receita arrecadada com a venda de recicláveis no mês)

25. Eficiência da coleta seletiva $(\mathbf{t} / \mathbf{k m} / \mathbf{h})$

( expressa a média de recicláveis coletados/ hora por $\mathrm{Km}$ rodado da coleta seletiva) Nota:

* IRMR $=\underline{\text { Ouantidade Coletada seletivamente }- \text { Ouantidade de rejeitos na triagem }} \times 100$

Quantidade coletada seletivamente + Quantidade coletada de lixo "comum"

** PEV - Posto de Entrega Voluntária $\quad * * *$ Indicador específico para Organizações de Catadores Autônomos 


\section{Anexo 03.}

Pesquisa Quantitativa (Fase 1)

Técnica Delphi - Indicadores de Coleta Seletiva 


\section{Técnica Delphi - Instrumento de pesquisa aplicado:}

Pesquisa sobre Indicadores para Coleta Seletiva de Lixo - Estudo de Caso

Considerando que os indicadores somente passam a ser utilizados, na prática, quando se apresentam relevantes, definiu-se como segunda etapa metodológica da validação de grupo de indicadores de coleta seletiva, a realização de um Estudo de Caso a partir da experiência do município de Vitória.

Assim, utilizando a Técnica Delphi foi elaborado o questionário a seguir onde são apresentados 25 indicadores, aos quais deverão ser atribuídas notas variando de 1 a 10 pelos técnicos envolvidos direta ou indiretamente com a questão da coleta seletiva no município de Vitória.

Tais notas deverão ser atribuídas a partir da avaliação pessoal do técnico quanto ao atendimento, por parte de cada um dos indicadores apresentados, a cada um dos critérios a seguir:

- Validade - refere-se à adequação do indicador para medir ou representar, sintéticamente, o fenômeno estudado.

- Confiabilidade (reprodutibilidade ou fidedignidade) - refere-se garantia de obtenção de resultados semelhantes, quando a mensuração é repetida.

- Representatividade (cobertura) - refere-se a cobertura alcançada pelo indicador em relação ao evento ou fenômeno estudado.

- Oportunidade, simplicidade, facilidade de obtenção e custo compatível - referese ao fato de que a obtenção dos dados deve causar o mínimo de perturbação ou inconvenientes, ou seja, não deve interferir nas condições habituais de funcionamento dos serviços além de ter custos compatíveis.

Além da nota para cada indicador tem-se o campo comentário, que é de preenchimento opcional, e permite a manifestação sucinta de alguma justificativa ou comentário relativa a nota atribuída ao indicador.

Para participar da pesquisa inicialmente informe os seus dados pessoais:

\section{I -Identificação do informante:}

.Nome:

.Formação acadêmica:

( ) graduação ( ) especialização ( ) mestrado ( ) doutorado

.Curso Superior:

.Cargo ou função: 
I - Listagem com os 25 indicadores do questionário, seguidos de sua definição:

1. Cobertura do Atendimento ( hab)

( expressa a parcela da população que é atendida pelo programa de coleta seletiva )

2. IRMR - Índice de Recuperação de Materiais Recicláveis (\%)

( expressa a quantidade de materiais reaproveitados pelas indústrias de reprocessamento)

3. Despesa com marketing e educação ( $\mathrm{R} \$ \mathbf{h a b} / \mathbf{a n o})$

(expressa as despesas anuais do programa com marketing e educação)

4. Investimento per capita anual no programa (R\$/ hab/ano)

( expressa o investimento per capita anual feito em infra-estrutura e pessoal )

5. Relação Receita/Despesa

( expressa a relação entre a receita da comercialização dos recicláveis e as despesas do programa)

6. Quantidade de PEV's instalados (un)

( expressa o tamanho do projeto a partir do total de PEV's instalados)

7. Quantidade mensal de catadores autônomos envolvidos na organização (catadores/mês)

( expressa o total de catadores trabalhando na organização no mês)

8. Preço médio de comercialização do "mix" de material reciclável (R\$/ t)

( expressa a média dos preços praticados na comercialização dos diversos materiais recicláveis por tonelada )

9. Freqüência média de coletas $\left(n^{\circ}\right.$ de coletas/ semana)

( expressa a relação entre os dias de coleta em relação ao total de dias da semana)

10. Produção média de Recicláveis por PEV (t/PEV)

( expressa a quantidade média em peso de recicláveis coletados por PEV )

11. Percentual de resíduos recicláveis no lixo da coleta regular (\%)

( expressa a parcela de recicláveis presente no lixo da coleta regular)

12. Densidade de Coleta $(t / h)$

( expressa a quantidade de recicláveis coletados por hora de operação da coleta)

\section{Percentual de rotatividade de catadores autônomos $(\%)$}

( expressa a relação entre o total de catadores trabalhando na organização no mês e a média de catadores que trabalharam na organização nos últimos seis meses)

14. Custo mensal de Operação da Coleta e Transporte $(\mathrm{R} \$ \mathbf{t})$

( expressa a relação entre o custo de coleta e transporte e o total de recicláveis coletados no mesmo período)

\section{Percentual mensal de reclamações/não conformidades $(\%)$}

( expressa a relação entre o $\mathrm{n}^{\circ}$ de reclamações sobre o programa de coleta seletiva e o $\mathrm{n}^{\circ}$ total de reclamações sobre o sistema de limpeza pública feita pelos usuários)

16. Percentual de resíduos orgânicos no lixo da coleta seletiva (\%)

( expressa a parcela de orgânicos presente no lixo da coleta seletiva)

17. Índice mensal de vandalismo PEV's (\%)

( expressa o ${ }^{\circ}$ de PEV's danificados em relação ao total de PEV's instalados)

18. Quantidade mensal coletada seletivamente ( $t /$ mês)

( expressa a quantidade de recicláveis coletados seletivamente no mês )

19. Custo de triagem $(\mathrm{R} \$ \mathbf{t})$

( expressa a relação entre o custo de triagem e o total de recicláveis processados no mesmo período)

20. Quantidade de itens de materiais recicláveis comercializados (un)

( expressa a quantidade de itens de recicláveis com mercado no programa)

21. Renda média mensal por catador autônomo (R\$/catador/mês)

( expressa o ganho mensal por catador que trabalha na organização)

22. Eficiência de mão de obra de triagem (t/trabalhador/hora)

( expressa a média do rendimento horário da mão de obra por tonelada processada)

23. Custo total da coleta seletiva (R\$/t) ( expressa a relação entre o custo de coleta, transporte e triagem e o total de recicláveis coletados no mesmo período)

24. Receita apurada em vendas ( $R$ \$ mês)

( expressa a receita arrecadada com a venda de recicláveis no mês)

25. Eficiência da coleta seletiva $(t / \mathbf{k m} / \mathbf{h})$

( expressa a média de recicláveis coletados/ hora por Km rodado da coleta seletiva) 


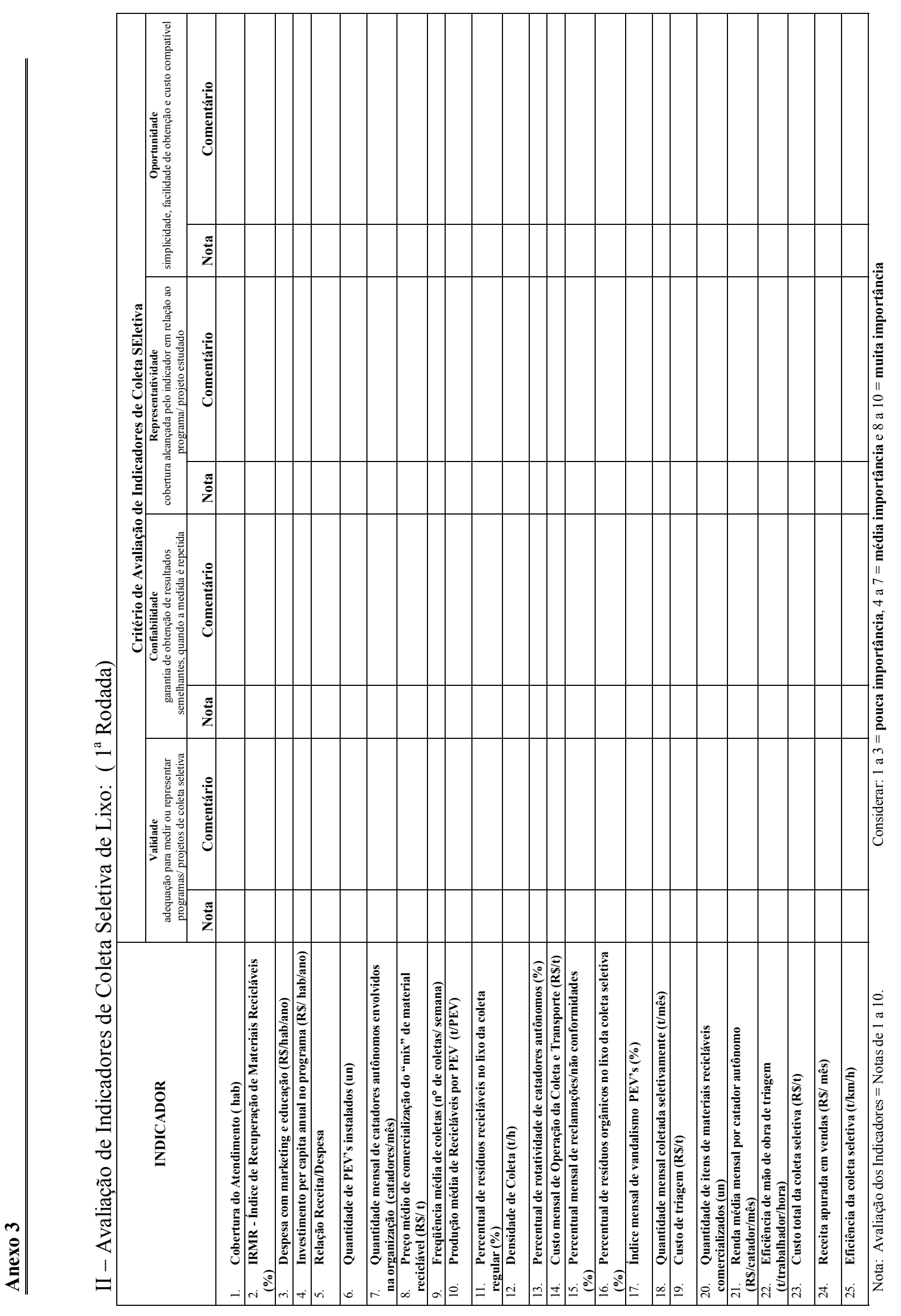




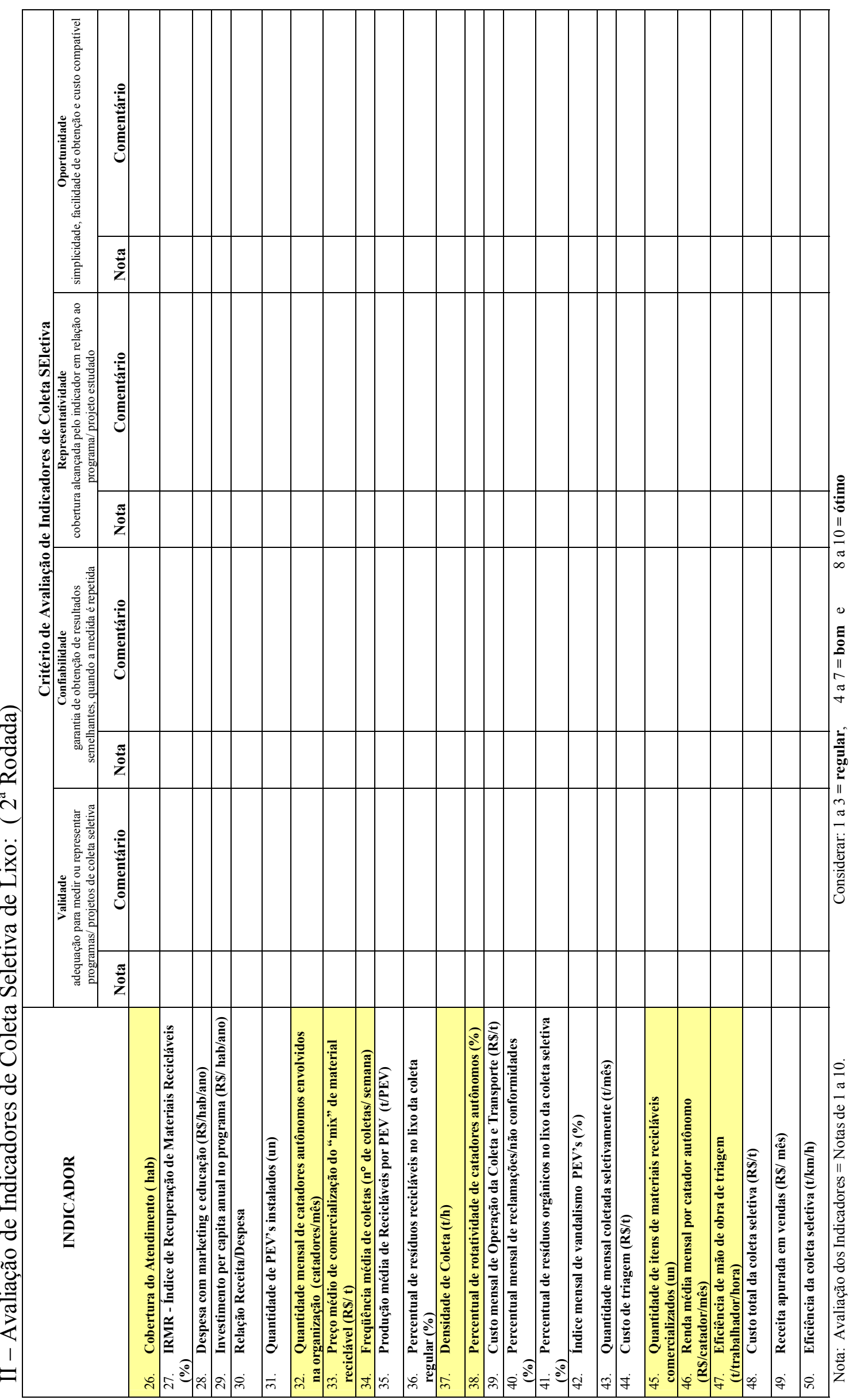


Anexo 04.

Pesquisa Qualitativa (fase 3)

Participação Social na Coleta Seletiva 


\section{Participação Social - Instrumentos de pesquisa aplicado:}

\section{Roteiro de Entrevistas - Pré-Teste}

Bom dia/ tarde!

Gostaria de fazer uma entrevista com o(a) senhor(a) sobre coleta seletiva de lixo.

O senhor pode me ajudar?

Essa entrevista servirá de base a um trabalho de pesquisa científica para avaliar a participação da população de Vitória em Programas de Coleta Seletiva de lixo desenvolvidos pela prefeitura.

Por exigência da Universidade teremos de gravar a entrevista.

$$
\text { Questionário - Etapa Piloto }
$$

\section{Modelo Qualitativo 1 \\ Regiões do município onde já existe Coleta Seletiva Comunitária}

1. Você já ouviu falar de Coleta Seletiva? Fale um pouco sobre isso.

2. Você participa da Coleta Seletiva do seu bairro?

caso sim vá para 2.1

caso não vá para 2.2

\subsection{Como?}

\subsection{Porque?}

3. Em certos lugares os programas de coleta seletiva começam bem e acabam sendo deixados de lado com o tempo. Porque você acha que isso acontece ?

4. Teria mais alguma coisa para falar? 


\section{.Desenvolvimento do Pré-teste:}

O pré-teste de aplicação do Questionário de Pesquisa Qualitativa foi realizado no bairro de Jardim da Penha, no dia 02 de maio de 2002.

Uma vez que no bairro Jardim da Penha a prefeitura havia implantado, desde 1998, a coleta seletiva por Postos de Entrega Voluntária - PEV foi utilizado o questionário modelo qualitativo 01.

Por julgar que seria mais fácil obter a adesão das pessoas num local de grande fluxo, optouse pela realização do pré-teste numa avenida movimentada do bairro rota de passagem das pessoas que vem do Campus da Universidade Federal e próximo ao horário do almoço, entre 11:00 e 12:00 h.

Foram abordados também os comerciantes do entorno.

Sendo o objetivo principal testar o entendimento das questões formuladas, o tempo da entrevista e a melhor forma de abordagem não foi rigorosamente seguido a estratificação definida para a amostra.

Tal estratificação era:

- 01 líder comunitário ou representante político local

- 01 morador entre 20 e 59 anos, sexo feminino

- 01 morador entre 20 e 59 anos, sexo masculino

- 01 morador com 60 anos ou mais, sexo masculino

- 01 morador com 60 anos ou mais, sexo feminino

- 01 comerciante ou industrial

O entrevistador era do sexo masculino, vestia-se de modo social, sem entretanto utilizar terno e gravata, utilizou um pequeno gravador de mão bastante discreto e uma prancheta com o questionário, caneta e algumas cópias do Termo de Consentimento para serem preenchidos. Não utilizou crachá de identificação. 


\section{. Resultados do Pré - Teste:}

O barulho do trânsito local e o vento atrapalhou a qualidade do áudio da gravação.

Foram abordadas 09 (nove) pessoas, 05 (cinco) aceitaram responder o questionário e nenhuma aceitou assinar o Termo de Consentimento. Dentre as pessoas que aceitaram temse a seguinte estratificação:

- 03 moradores entre 20 e 59 anos do sexo feminino;

- 01 morador entre 20 e 59 anos do sexo masculino;

- 01 comerciante;

As pessoas que tiveram maior resistência em aceitar a entrevista estão as do sexo masculino com 60 anos ou mais.

$\mathrm{Na}$ abordagem o pesquisador perguntava se a pessoa era moradora do bairro, caso positivo, solicitava a colaboração com a pesquisa e perguntava a idade. Informava que teria que gravar e aplicava o questionário. Ao final solicitava os dados pessoais para preencher o Termo de Consentimento e pedia a assinatura.

\begin{tabular}{|c|c|}
\hline Aspecto & Resultado \\
\hline $\begin{array}{l}\text { 1. Entendimento } \\
\text { das questões }\end{array}$ & $\begin{array}{l}\text { Foram observadas dúvidas no entendimento da primeira pergunta, } \\
\text { que trata do significado da coleta seletiva. } \\
\text { A segunda e terceira questão foram bem absorvidas pelos } \\
\text { entrevistados. } \\
\text { A quarta questão, que abre espaço para o entrevistado falar de forma } \\
\text { livre mais alguma coisa não foi utilizada. }\end{array}$ \\
\hline $\begin{array}{l}\text { 2. Método de } \\
\text { pesquisa }\end{array}$ & $\begin{array}{l}\text { Dentre os que se recusaram a participar da pesquisa houve a } \\
\text { justificativa de não aceitar ser gravado. } \\
\text { Necessidade de aprimorar o Roteiro de pesquisa de campo de modo a } \\
\text { conduzir melhor o entrevistado e ter-se mais organização no registro } \\
\text { dos resultados. } \\
\text { Necessidade de estratificar mais a amostra. }\end{array}$ \\
\hline $\begin{array}{l}\text { 3. Fornecimento } \\
\text { dos dados } \\
\text { pessoais }\end{array}$ & $\begin{array}{l}\text { As pessoas abordadas apresentaram resistência em fornecer dados } \\
\text { pessoais, como o número do R.G. , apenas parte dos entrevistados } \\
\text { concordaram em fornecer o nome completo e idade. }\end{array}$ \\
\hline $\begin{array}{l}\text { 4. Termo de } \\
\text { Consentimento }\end{array}$ & Não se conseguiu a assinatura dos entrevistados. \\
\hline
\end{tabular}




\section{$1^{\circ}$ Etapa - Versão Final do Questionário (EI QI)}

Bairros selecionados: Jardim Camburi e Mata da Praia (bairros com coleta seletiva implantada)

Bom dia, tarde!

O Sr.(a) mora neste bairro ?

(caso sim, continuar a pesquisa)

Gostaria de fazer uma entrevista com o(a) senhor(a) sobre coleta seletiva de lixo.

Essa entrevista servirá de base a um trabalho de pesquisa científica para avaliar a participação da população de Vitória em Programas de Coleta Seletiva de lixo desenvolvidos pela prefeitura.

Por exigência da Universidade teremos de gravar a entrevista.

O senhor(a) concorda em participar?

Nome completo e idade?

\section{Questionário I}

1. Você já ouviu falar de Coleta Seletiva? Fale um pouco sobre isso.

2. Você participa da Coleta Seletiva em seu bairro?

caso sim vá para 2.1

caso não vá para 2.2

\subsection{Como?}

\subsection{Porque?}

3. Em certos lugares os programas de coleta seletiva começam bem e acabam sendo deixados de lado com o tempo. Porque você acha que isso acontece ?

4. Teria mais alguma coisa a falar?

Como trata-se de um trabalho científico necessitamos de sua assinatura e número de identidade para assegurar a veracidade dos dados. O senhor pode assinar?

Obrigado pela colaboração! 


\section{$1^{\circ}$ Etapa - Versão Final do Questionário II (EI QII)}

\section{Bairros selecionados: Praia do Suá, Jucutuquara, Ilha de Monte Belo e Bairro de Lourdes (bairros sem} coleta seletiva)

Bom dia, tarde!

O Sr.(a) mora neste bairro ?

(caso sim, continuar a pesquisa)

Gostaria de fazer uma entrevista com o(a) senhor(a) sobre coleta seletiva de lixo.

Essa entrevista servirá de base a um trabalho de pesquisa científica para avaliar a participação da população de Vitória em Programas de Coleta Seletiva de lixo desenvolvidos pela prefeitura.

Por exigência da Universidade teremos de gravar a entrevista.

O senhor(a) concorda em participar?

Nome completo e idade?

\section{Questionário II}

1. Você já ouviu falar de Coleta Seletiva? Fale um pouco sobre isso.

2. Você estaria disposto a participar da Coleta Seletiva em seu bairro?

caso sim vá para 3.1

Caso não vá para 3.3

3.1 Como?

$3.2 \mathrm{O}$ que te motiva a participar?

3.3 Porque?

3. Em certos lugares os programas de coleta seletiva começam bem e acabam sendo deixados de lado com o tempo. Porque você acha que isso acontece?

4. Teria mais alguma coisa a falar ?

Como trata-se de um trabalho científico necessitamos de sua assinatura e número de identidade para assegurar a veracidade dos dados. O senhor pode assinar?

Obrigado pela colaboração! 


\section{$2^{\circ}$ Etapa - Versão Final do Questionário I (EII QI)}

Bairros selecionados: Jardim Camburi, Praia do Suá, Jucutuquara, Ilha de Monte Belo

Bom dia, tarde!

O Sr.(a) mora neste bairro ?

(caso sim, continuar a pesquisa)

Gostaria de fazer uma entrevista com o(a) senhor(a) sobre coleta seletiva de lixo.

Essa entrevista servirá de base a um trabalho de pesquisa científica para avaliar a participação da população de Vitória em Programas de Coleta Seletiva de lixo desenvolvidos pela prefeitura.

Por exigência da Universidade teremos de gravar a entrevista.

O senhor(a) concorda em participar?

Nome completo e idade?

\section{Questionário I}

1. Você já ouviu falar de Coleta Seletiva e de reciclagem do lixo? Fale um pouco sobre isso.

2. Você participa da Coleta Seletiva em seu bairro?

caso sim vá para 2.1

caso não vá para 2.2

2.1 Como?

2.2 Porque?

3. Em certos lugares os programas de coleta seletiva começam bem e acabam sendo deixados de lado com o tempo. Porque você acha que isso acontece?

4. Teria mais alguma coisa a falar ?

Como trata-se de um trabalho científico necessitamos de sua assinatura e número de identidade para assegurar a veracidade dos dados. O senhor pode assinar?

Obrigado pela colaboração! 
FICHA DE CONTROLE - PESQUISA DE CAMPO QUALITATIVA

\section{Bairro:}

Data das Entrevistas:

01 morador entre 16 e 29 anos, sexo feminino

01 morador entre 16 e 29 anos, sexo masculino

01 morador entre 30 e 59 anos, sexo feminino

01 morador entre 30 e 59 anos, sexo masculino

01 morador com 60 anos ou mais, sexo masculino

01 morador com 60 anos ou mais, sexo feminino

01 Líder Comunitário ou representante político local - Nome:

01 comerciante ou 01 industrial - Comerciante

industrial

Se recusaram a dar entrevistas:

Se recusaram a assinar:

\section{Observações:}




\section{TERMO DE CONSENTIMENTO LIVRE E ESCLARECIDO}

Vitória, de julho de 2002

$\mathrm{Eu}_{2}$

$\mathrm{RG} \mathrm{n}^{\circ}$ , declaro para os devidos fins que autorizo a utilização das informações coletadas na entrevista realizada nesta data pelo entrevistador para fins de trabalho acadêmico e publicações, sem restrições de prazos e citações, desde a presente data. Da mesma forma autorizo a sua audição e o uso das citações a terceiros.

assinatura do entrevistado 


\section{Discursos do Sujeito Coletivo - DSCs}

\section{Pergunta 1:}

EI P1 - Você já ouviu falar de Coleta Seletiva? Fale um pouco sobre isso.

EII P1 - Você já ouviu falar de Coleta Seletiva, da Reciclagem do lixo? Fale um pouco sobre isso.

Idéia Central: Já ouviu falar, coleta seletiva refere-se ao lixo e a sua separação

\section{DSC EI Q1 P1 (S1)}

Já ouvi falar sim, é a respeito do lixo?. É a coleta de lixo, né?

Agora tem a separação do lixo orgânico e inorgânico.

Já participei no meu setor de trabalho.

A coleta seletiva já está sendo feita na praça próxima, onde é separado todo o tipo de material. É importantíssimo, né ? ...A recuperação do caseiro, industrial.

\section{Idéia Central: Já ouvi falar, coleta seletiva refere-se à prefeitura}

\section{DSC EI QI P1 (S2 e S3)}

Coleta Seletiva do lixo é o projeto da prefeitura para separar o lixo que possa ser reciclado. Tenho visto, dentro desse projeto vários contêineres com lugares específicos aonde à população deve separar o seu próprio lixo".

Já ouvi falar aqui no bairro, mas não tenho maiores conhecimentos. Eles começaram a desenvolver este projeto a bem pouco tempo.

Acho um bom trabalho, uma boa medida, interessante porque ajuda a prefeitura. Quando o lixo vai todo junto, tem de separar.

A coleta seletiva conscientiza a população de que todos podemos ajudar. A prefeitura deveria trabalhar mais em cima de conscientizar o povo. 


\section{Idéia Central: Coleta seletiva é a coleta de lixo domiciliar}

\section{DSC EI QII P1 (S1)}

Sim, eu já ouvi falar da coleta seletiva. A coleta seletiva tem que ser todo dia entre seis e nove horas, eu acho.

Ultimamente, não tenho visto a coleta seletiva aqui no bairro, nem aqui no bairro nem no bairro de São Cristóvão. A freqüência tem sido bem menor."

\section{DSC EI QII P1 (S2)}

Da coleta Seletiva? Do caminhão que passa para recolher o lixo todos os dias?

Coleta seletiva é a coleta do lixo doméstico que se faz todos os dias pela prefeitura.

A coleta de lixo aqui é boa, não há problema. Quase todo dia tem caminhão de lixo aí, apanha o lixo nas peixarias, tem sempre um varredor de rua também.

Ela melhorou muito de 1992 pra cá, nós estamos tendo uma participação constante da empresas. É uma atividade que só tem a ganhar.

O pessoal aqui tá conscientizado tem um horário determinado, que coloque o lixo exposto para que façam a coleta. Não tenho muita informação sobre isso.

\section{Idéia Central: Coleta seletiva ajuda a resolver o problema do lixo}

\section{DSC EI QII P1 (S3)}

Já ouvi falar sim. Vejo que está sendo bem executado, né?

A vizinhança está achando legal. Essa coisa do lixo orgânico, dos descartáveis, até mesmo para o trabalho das pessoas, melhora a seleção do lixo.

Eu achei uma coisa bacana. Quando tem vidros, latas, essas coisas que pode cortar o lixeiro porque está tudo misturado. Fica melhor separar logo né?

A gente vê em reportagem na televisão falando que é uma coisa boa o reaproveitamento do lixo, reciclagem do lixo. É uma coisa que poderia ser feito. É um programa que deve ser bem desenvolvido. 


\section{DSC EI QII P1 (S4)}

Já ouvi falar em rádios, revistas, telejornais e outros meios de comunicação, conheço o trabalho, embora a população não esteja bem conscientizada para isso. Só algumas grandes empresas, e alguns setores da prefeitura estão trabalhando com isso. É um programa que a Prefeitura de Vitória, se não me engano, junto com o Estado, vem tentando desenvolver para tentar resolver.

Só que não é muito freqüente aqui. A gente não vê o trabalho efetivo deles.

Falta um trabalho de conscientização mostrando as pessoas que o lixo não era lixo. Nós não temos como trabalhar porque não há investimento nessa área.

As pessoas em Vitória já tem conhecimento maior da necessidade de se fazer a coleta seletiva, a separação do lixo, fazer com que o meio ambiente seja menos agredido e traga menor despesa ao município.

O problema do lixo que, por incrivel que pareça, daqui a alguns anos vai ser o grande filão de dinheiro do Estado e até da população.

\section{Idéia Central: Coleta seletiva é separar o lixo}

\section{DSC EI QII P1 (S5)}

Coleta seletiva? Ah! Lembrei. É aquele, que tem uns troços lá que coloca o lixo de plástico, vidro, papel, papelão né, essas coisas.

É separar o lixo. Essa coisa do lixo orgânico, do descartáveis, até mesmo para o trabalho das pessoas. Coleta seletiva é separação de lixos recicláveis, os plásticos dos vidros e outras coisas mais, visando o reaproveitamento, a reciclagem desse material. Que podem se tornar novas matérias primas.

Então você separa lixo, separa o lixo, separa lata, separa papel.

O lixo orgânico também tem seu destino. 


\section{Idéia Central: A coleta seletiva e a reciclagem referem-se ao lixo e a sua separação}

\section{DSC EII QI P1 (S1)}

A reciclagem é.... é sobre o... ai no momento eu esqueci aqui, eu não sei nem como me expressar. Mas a coletagem de lixo é sobre deixar a cidade limpa. Eu acho que muita gente aqui sabe, né ? E concorda também. Da recicragem também

Já tivemos representante da prefeitura em uma reunião explicando, sobre esse sentido. É o material que a gente usa e os resíduos são reaproveitados né?

Eu achei assim maravilhoso porque a gente divide é ... aqueles frascos né refrigerante, de várias coisas e coloca o lixo no lugar, alguns depósitos que a prefeitura já colocou em vários bairros.

Sempre se tem que tá juntando o lixo direitinho, tá separando os da reciclagem e tá colocando no dia certo no latão de lixo, né?

Acho muito bom, só que está sendo implantado mas não tá atendendo a comunidade como precisa. Eu acho que tá muito pouco, pouca caixa de coleta entendeu? Tem que ter mais.

\section{DSC EII QI P1 (S2)}

Aquele negócio de reciclagem, de dividir. Já ouvi. Separar o lixo do ... o lixo do que dá para reciclar É uma boa medida.

Do jeito que o pessoal tá fazendo tá indo bem né?

Tem que ter isso em todas as cidades não só em cidades grandes mas eu acho em cidades pequenas principalmente e meio rural.Eu acho que tem que ser obrigatório.

A coleta seletiva e a reciclagem do lixo tem que ser abrangente. É o futuro de tudo

\section{DSC EII QI P1 (S3)}

Já ouvi falar sobre a coleta seletiva e reciclagem, aquela que você seleciona vidro, alumínio, plástico e comida.

Estamos fazendo no prédio. Acho muito importante essa separação do lixo.

A reciclagem ajuda em todos os sentidos. Além de colocar o lixo no devido lugar. É fundamental, mais higiênco e bem proveitoso.

Ela vem beneficiar a qualidade de vida dos moradores, é mais uma forma das pessoas ter como separar o lixo do lixo e ao mesmo tempo até beneficiando a comunidade. 
A secretaria de meio ambiente implantou em cinco regiões e Jardim Camburi é uma das comunidades que mais aderiu à coleta seletiva e que mais a população foi educada e hoje funciona. Acredito que com um tempo, seis meses à um ano, teremos quase cem por cento com o lixo reciclado e separado.

\section{Idéia Central: Nunca ouviu falar da coleta seletiva}

\section{DSC EII QI P1 (S4)}

Eu junto meu lixo e eles levam, vejo aí falar de reciclagem mas nunca vi como é que faz. Eu sei o que a prefeitura fala, não entendo nada, só ouvi falar superficialmente.

Eu não posso falar que eu não intendo não. Só sei que aqui nós pagamo eles panha o lixo e tudo, agora a coletage de lixo o que quê eles faz com o lixo eu não sei. Eles acabam indo lá na usina. Agora eu nuca fui lá na usina. Agora eu nunca fui lá, nunca vi, né? Aqui no bairro tá tudo certinho, o carro recolhe de noite, não tenho nada a reclamar.

\section{Idéia Central: A reciclagem do lixo refere-se à prefeitura}

Pergunta 2/2.1:

QI P2 - Você participa da Coleta Seletiva em seu bairro?

EI 2.1 Caso sim, como?

QII P2 - Você estaria disposto a participa da Coleta Seletiva em seu bairro?

EI 2.1 Caso sim, como o(a) Sr(a) participaria? O que te motivaria a participar?

\section{Idéia Central: Participo da Coleta Seletiva separando o lixo}

\section{DSC EI Q1 P2/2.1 ( S1)}

Participo. Colocando os lixos de acordo com... se é seco, se é molhado. O que eu acho que pode servir para alguém eu não misturo não. Muita coisa que vai para o lixo se aproveita. A gente separa o que é vidro, que é plástico, que é lata, papel. E tem próximo aqui numa praça, a Prefeitura colocou um treco especial para se colocar. 


\section{Idéia Central: Participo da Coleta Seletiva junto à comunidade}

\section{DSC EI Q1 P2/2.1 (S2)}

Como líder comunitária dizer que não participaria seria fugir do meu direito de cidadania e ajudar a minha comunidade.

Eu acredito que tem pessoas aqui já participam dessa coleta seletiva. Meu caso é verificar, fazer um campanha junto a comunidade."

O trabalho do líder de coleta do lixo seria maior incentivo a população para que participe. Não adianta ter contêiner lê e ninguém ir lá colocar.

\section{Idéia Central: Participaria da coleta seletiva separando o lixo}

\section{DSC EI QII P2/2.1 (S1)}

“Estou, claro! Eu estaria disposto a participar. Com certeza eu iria ajudar de todas as maneiras, na minha casa e também em trabalhos voluntários.

Reciclando o meu lixo. Separar aquilo que eu sei que vai ser reaproveitado e o lixo orgânico. Separando os vidros, as latas.

A coleta seletiva ajuda a resolver uma série de problemas. Eu me sentiria orgulhoso em participar disso."

\section{DSC EI QII P2/2.1 (S2)}

Se houvesse oportunidade, eu participaria fazendo a separação em minha residência e incentivando os vizinhos.

Ia ajudar em alguma coisa, eu acho que falta incentivo a população de ter consciência sobre, eles próprios nas residências separarem o lixo, essa coisa de ... essa coisa do cuidado, acho que falta isso.

A questão do lixo é um problema muito sério no mundo em geral, no nosso país a comunidade é a principal arma para que a coleta seja feita de forma eficaz.

Se todo mundo fizer a gente faz. É bom é interessante, diminuiu o risco para quem vai colher o lixo, essas coisas todas. 


\section{DSC EI QII P2/2.1 (S3)}

Participaria sim se não for me locomover demais. Pelo menos a gente veria o bairro limpo. Isso é uma coisa para melhoraria do bairro, a gente precisa de colaborar e também participar.

Eu gostaria que tivesse condições de ser feito, a gente separaria o lixo para colocar nos recipientes adequados.

Agora sair da minha casa para passar para os outros eu não posso porque eu tenho o meu trabalho. Seria uma coleta seletiva "domestical".

\section{Idéia Central: Participaria da coleta seletiva pelo meio ambiente}

\section{DSC EI QII P2/2.1 (S4)}

Eu iria ajudar porque melhoraria muito o meio em que vivemos, gerar no caso mais emprego lá fora, estaria ajudando também a tirar o lixo da rua. Limpeza do bairro, melhor qualidade de vida dos moradores e uma cidade limpa.

Eu participaria separando o lixo.

Me motivaria se fosse um trabalho bem feito, troço mais organizado, direitinho. Saber que estou contribuindo para resolver um problema ecológico. Saber que esse material que estou separando para a reciclagem não vai ficar poluindo nossos rios, nossas terras. É bom para o meio ambiente. É uma coisa que a gente contribuiria para natureza de certa forma

Todos esses materiais, eles vão para os aterros sanitários. O dinheiro gasto com a coleta de lixo, o aterro sanitário, agredindo o meio ambiente, ele é alto, quando você faz a coleta seletiva traz menor custo para o município e essa verba pode ser destinada para áreas sociais.

Eu acho que a organização é cuidado com a preservação ambiental.

\section{DSC EI QII P2/2.1 (S5)}

É uma coisa que ajuda muito, tem muita coisa errada nesse nosso Brasil, nessa prefeitura... principalmente esse pessoal que chega ali na sacola de lixo da gente. Eles vão e rasgam e jogam tudo no chão, então ficam os cachorros jogando tudo no chão, fica 
difícil para gente limpar depois, os lixeiros pegam o que está sacola e vão embora, o que fica no chão não.

\section{DSC EI QII P2/2.1 (S6)}

É tão questionado que o brasileiro joga tanta coisa no fora, o lixo é tão desprezado e muita gente vive até disso, coletando latinha, coletando plástico para sobreviver. Então de repente, é uma coisa mais correta, seletiva mesmo de separar o lixo.

O que motivaria a mim, motivaria a todos, seria a limpeza pública organização da nossa cidade, do nosso bairro, até ajudaria a educar mais a população. Que hoje em dia é triste.

\section{Idéia Central: Participaria da coleta seletiva se houvesse organização e estrutura}

\section{DSC EI QII P2/2.1 (S7)}

Dependendo de como a administração vem fazendo, a gente também participa. Primeiro tem que saber como é que vai fazer, ser orientado. O convite de alguém né? O que mais me motivaria seria colocar pontos estratégicos, para que não haja bagunça na rua, como lixo esparramado em todo o lugar ou como tem aí.

O mais importante da coleta seletiva é um local apropriado. É preciso ter um local específico, porque qualquer coisa que você fala em relação a coleta de lixo incomoda a comunidade, se você coloca uma caixa na frente do cara ali, ele pode não gostar porque todo mundo vai jogar lixo ali, entendeu?

Porque realmente para levar até o local que a prefeitura coloca fica longe da casa, a pessoa tem preguiça e acaba não indo.

Tudo que a população aceita como algo correto e benefício para si próprio é válido para que todo mundo participe. 


\section{Idéia Central: Participo da Coleta Seletiva junto à comunidade}

\section{DSC EII Q1 P2/2.1 ( S1)}

Participo falando com o pessoal e reciclando o meu lixo, separando o lixo do molhado e do seco. Fazendo essa divisão do lixo doméstico. Separando o lixo pra reciclagem e lixo pra não reciclagem.

A associação de moradores faz um acompanhamento através da conscientização aos moradores para que estejam colocando o lixo no horário determinado pela prefeitura, explicando o que é reciclável ou não.

A associação comunitária hoje dá informativo do jornal dizendo aos moradores que adeque ao sistema, aquela coleta seletiva do lixo seco e do lixo molhado. A secretaria de meio ambiente até nos deu parabéns por ter a melhor participação dentre outras comunidades.

\section{DSC EII Q1 P2/2.1 ( S2)}

Não tem o dia do lixo né? Terça e sexta feira e os outros dias do molhado. A gente participa separando o lixo no nosso condomínio, justamente fazendo essa divisão do lixo doméstico.

Segue essa regra ai da prefeitura. Da forma que eles decidiram de fazer aquela coleta seletiva do lixo seco e do lixo molhado. Na separação do Lixo

Em casa já deixam o lixo separado, então desço com o lixo separado já. Aí o coletor vem e leva.

Então eu acho que é muito importante né? Fazer coleta, separar o lixo não custa né? É muito aproveitoso.

\section{Idéia Central: Participo da Coleta Seletiva separando o lixo}

\section{DSC EII Q1 P2/2.1 (S3)}

Como eu participo é ... agora eu não sei ... não sei te informar. Juntá o lixo para o povo levá, no caso?

Eu sei que nós panha o no... o lixo todo dia e eles panha, o coletor vem e leva. 
Separo o lixo seco do lixo ... esse lixo podre né, resto de comida. Mas agora eles não estão nem recolhendo, sabe por que? O pessoal coloca ... não separa né, deixa lá. Ontem mesmo num recolheram. Tá tudo lá no meio da rua. Que o pessoal que bota fora de hora, de dia né, não tem um horário certo pra colocar.

O povo ainda não está ainda assim ... conscientizado do que tem que fazer e o que tá acontecendo é que o nosso bairro tá ficando muito sujo.

Meu lixo eu coloco nos lugar próprio que o caminhão já passe e pegue nunca deixo na minha porta se tivesse um local próprio que nas ruas colocassem os lixos seria melhor, às vezes o caminhão do lixo demora muito a passar. E esse lixo ficando jogado nas portas passa gente chutando. Então eu acho importante aqui tivesse um lugar próprio pra cada morador colocar o lixo. É um meio de educar ... facilitar ao morador

\section{Pergunta 2/2.2:}

QI P2 - Você participa da Coleta Seletiva em seu bairro?

2.2 Caso não, porque?

QII P2 - Você estaria disposto a participa da Coleta Seletiva em seu bairro?

2.2 Caso não, porque?

\section{Idéia Central: Não participo por falta de oportunidade e/ou acomodação}

\section{DSC EI Q1 P2/2.2 (S1)}

Não sou eu que levo o lixo para a rua. Esse negócio fica lá em casa a cargo da mulher ... então não participo.

\section{DSC EI Q1 P2/2.2 (S2)}

Falta oportunidade. Só tem uma coleta no bairro ... dificulta pra gente. O local que é de coleta seletiva é longe da minha casa. O caminhão que se passa em frente a casa não faz a coleta seletiva.

\section{DSC EI Q1 P2/2.2 (S3)}

Fico a maior parte do tempo fora de casa, na hora que o lixeiro passa eu não estou em casa. A moça que trabalha aqui faz a coleta no meu lixo doméstico. Ela não separa, tem 
que estar orientando. Eu mesmo não levo lá e não vejo sendo colocado. Sei que vou criar um caso com a minha secretária, se eu pedir para ela ir e ela não for. Nesse caso nem peço, porque sei que é um mal menor.

\section{Idéia Central: Não participaria}

\section{DSC EI QII P2/2.2 (S1)}

Eu não sei, tem que saber como é para fazer. No meu bairro ainda não tem coleta separada, né? Pra mim eu acho que não daria por causa do meu serviço.

\section{Idéia Central: Não participo por falta de informação e estrutura}

\section{DSC EII QI P2/2.2 (S1)}

Não. Eu participo no meu ... da minha casa né? Eu tiro o lixo de dentro de casa ... procuro colocar na hora que ... o gari vai passar.

Lá ainda não tem marcado os lugares de colocar o lixo. A caixa é lá em baixo, aqui em cima não tem uma caixa. Então meu lixo é colocado ensacolado e o rapaz pega toda à tarde.

Não sei quem tá no meio, que mexe com isso. Só sei o horário que os gari passa para recolher os lixos.

\section{DSC EII QI P2/2.2 (S2)}

Não participo porque não tenho informação, não sei como é que funciona. Ninguém falou nada para mim participar, nem entendo bem essas coisas.

É porque eu acho que não tem necessidade, que tem muita gente na comunidade, né?

E o custo também fica muito caro, porque a pessoa vai comprar quantos centos de sacos de lixo pra botar um em cada um. Onde eu resido tem diversas caixas de lixo pra botar qualquer tipo de lixo, ai eu coloco lá. Porque aqui o lixo é recolhido tudo junto né?

Não fazem coleta seletiva, eles fazem coleta coletiva. Aqui só tem aquele contêiner ali perto do ponto de ônibus. 


\section{DSC EII QI P2/2.2 (S3)}

Nós no comércio não fazemos a seletiva, separar vidro, plástico, isso aí não. Haveria assim como se fosse só uma pré, né ? Aqui nosso ramo aqui é cópias Então nós separamos o lixo do papel e o lixo que a gente usa. Por exemplo, o alimento de seco de molhado aqui a gente faz. Mas dentro desse seco né, seria feita a triagem.

\section{Idéia Central: Não participo por falta de tempo}

\section{DSC EII QI P2/2.2 (S4)}

Não, nem em casa fico. Sempre estou fora de casa, trabalhando. Eu trabalho muito fora, não tenho tempo, não de recolher lixo, de separar, colocar lixo na rua.

Não sou eu que mexo com isso lê em casa. Não despertei pra isso entendeu?!

Meu filho, deixei pra ele!!

Pergunta 3:

P3 - Em certos lugares os programas de coleta seletiva começam bem e acabam sendo deixados de lado com o tempo. Porque você acha que isso acontece ?

\section{Idéia Central: Acontece por falta de interesse e acomodação}

\section{DSC EI QI P3 (S1)}

Acontece porque as pessoas não participam, não dão valor. Esse trabalho que é muito importante. Falta interesse da população, pode acontecer de ter no bairro e as pessoas não usarem. A prefeitura acaba tirando em forma de protesto contra a população.

O povo não preserva o que é nosso. A maioria do brasileiro é bastante relaxado.

O povo não continua tudo que começa, tem o incentivo de se iniciar, daí a pouco aquilo para, o povo parece que não tem aquela vontade de ver cosas bonitas.

As pessoas não costumam ajudar, colaborar, então acabam esquecendo, não continuando. Falta à pessoa arrumar um tempo para separar, e levar no local onde é feita a coleta. A pessoa se acomoda muito fácil com as coisas né?

Os catadores passam e pegam papelão, plástico que interessa e morador vai ficando acomodado. 
Estão trabalhando direitinho né, coletando o lixo. O povo não respeita, fica tudo sujo, o povo é culpado né.

\section{Idéia Central: Acontece por falta de educação, conscientização e estímulo}

\section{DSC EI QI P3 (S2)}

Acontece devido à educação. Em Jardim Camburi o pessoal tem um nível um pouco melhor. Sabem que isso ai é pra evitar proliferação de doenças, de vir ratos. Então aqui funciona.

\section{DSC EI QI P3 (S3)}

Falta de estímulo do poder público, conscientização e educação do povo. A prefeitura junto com as lideranças, está faltando isso, uma conscientização com a comunidade.

Falta incentivo por parte da prefeitura, do governo de fazer mais campanhas evidenciando a importância do projeto.

Devia incentivar e fazer prosseguir o projeto. É necessário pelos meios de comunicação, fazer essa propaganda.

Falta esclarecimento, falta mesmo uma campanha nesse sentido.

Tudo que você faz e não dá corda, até o relógio para. Então a coleta de lixo está fadada a não ser bem sucedida se não houver um estimulo.

\section{Idéia Central: Acontece por falta de educação, conscientização e estímulo}

\section{DSC EI QII P3 (S1)}

Acontece por falta de participação, relaxo da comunidade.

Desinteresse. Falta de colaboração. É justamente isso, preguiça da pessoa sair de casa para levar até o local onde são colocadas as lixeiras da prefeitura.

A pessoa começa e depois se acomoda. Tem que ser feito com amor e com capricho, as coisas andam, mas se começar a relaxar, acaba.

\section{DSC EI QII P3 (S2)}

É uma coisa que deve ser feita em conjunto, com todas as pessoas da cidade. 
Algumas pessoas já tem o vício, o hábito de jogar as coisas no chão, por falta as vezes de instrução, conhecimento, orientação.

A coleta seletiva já é uma coisa mais complicada. Se uma pessoa não tem preparo pra pegar o lixo que ela tem e jogar na lata, para ele jogar numa coleta seletiva vai ser muito mais difícil ainda.

Eu acho que a comunidade tem que ser vigilante, tem que marcar presença constante. A partir do momento em que você é contribuinte, tem mais que direitos de estar cobrando.

Não há muita colaboração para isso. As pessoas pensam assim: Ah, a gente já paga os impostos, o lixo tem mais é que jogar de qualquer jeito. Acomodação das pessoas, né?

O brasileiro é muito acomodado e preguiçoso para separar os negócios. Depende do povo, né?

As autoridades tem que incentivar e não deixar passar no esquecimento.

\section{DSC EI QII P3 (S3)}

Precisa de incentivo, que a prefeitura ou órgão responsável espalhe panfletos, conscientize a população.

Devia ter uma equipe de casa em casa, fazendo um trabalho para conscientizar as pessoas.

É uma responsabilidade do poder público local, não deixar esquecido. O município tem que criar incentivos com cooperativas, tirar esses catadores de ruas, fazer reuniões com as comunidades, fazer com que esta questão da coleta seletiva, da seleção do lixo, esteja presente e nunca seja esquecido. É um trabalho que deve ser feito a longo prazo.

Qualquer projeto, quando se torna uma prática comum, fica evidenciado por todos e todos tem o dever dessa participação. A gente faria uma coleta seletiva normalmente.

\section{Idéia Central: Acontece por falta de estrutura e divulgação}

\section{DSC EI QII P3 (S4)}

Não houve orientação adequada.

No momento em que é colocado a lixeira da prefeitura as pessoas podem até ter um incentivo para fazer essa coleta. 
O povo não está conscientizado. Talvez porque não foi divulgado o resultado, o benefício. Se for feito um tipo de propaganda, de conscientização a nível de meios de comunicação do benefício que esta coleta está fazendo acredito que as pessoas vão ter incentivo de continuar, colaborar fazendo a coleta seletiva. Elas não devem saber a verdade, qual o destino desse lixo, para quê está sendo útil esta separação que está fazendo o lixo.

Falta esclarecimento com o pessoal do bairro, conscientização da população e também órgãos que trabalham na divulgação, apoio, pessoas para poder incentivar as pessoas a trabalharem desta forma.

\section{DSC EI QII P3 (S5)}

Acontece pelas forças governamentais e municipais, o descaso dos órgãos, que começam e não dão continuidade não fazem um trabalho de divulgação para incentivar a pessoa a dar continuidade a esse processo.

Muitas vezes é interesse de algumas pessoas para que possam implantar esse tipo de coisa. Assim que termine o interesse é tudo abandonado, largado, como a gente vê muito em nosso país.

As pessoas desenvolvem aquilo para fazerem propaganda, as vezes na época de politica. Quando as redes de televisão deixam de lado, param de vigiar, deixam distorcer, os contratos ficam ao rigor da banalidade até dar tudo errado.

Isso acontece não só em Vitória, mas também em outras cidades que já tem isso implantado.

É responsabilidade do poder público local, principalmente o municipal, e não pode deixar a o esquecido, basta dizer que o brasileiro tem memória curta.

O municipio tem que se fazer presente a cada momento, criar incentivos com cooperativas, tirar esses catadores de ruas, fazer reuniões com as comunidades, fazer com que esta questão da coleta seletiva, da seleção do lixo, esteja presente e nunca seja esquecida ... Isso é um trabalho que deve ser feito ao longo prazo.

Falta organização, o pessoal acaba desistindo. A prefeitura não dá assistência, culpo mais a prefeitura. 


\section{Idéia Central: Acontece por falta de educação, conscientização e estímulo}

\section{DSC EII QI P3 (S1)}

Acontece porque o povo não está muito informatizado. $O$ nosso povo ainda não estava preparado para esse tipo de trabalho, a rejeição do povo é grande nesse sentido.

O povo não tem educação para seguir umas normas dessas.

O povo não colabora, não tem consciência que tem que jogar no lugar certo. Aí vai juntando lixo pela rua, o cachorro vai espalhando e vira aquela bagunça.

Aquele negoço de terça-feira lixo seco e lixo molhado parece que não deu certo, que a população não entendeu.

Não há a educação, pra pessoa incutir isso na cabeça é ter isso como modo de vida.

As pessoas começam naquela empolgação da implantação e depois esquecem com o tempo. O pessoal vai se desgastando, perde o incentivo.

As pessoas esqueciam. Deixavam pra lá e acabavam esquecendo. Teria que ter um trabalho mais forte para conscientizar o cidadão.

Á coisa importante isso aí de coleta.

Um acompanhamento quase que diário faz com as pessoas se conscientiza que a coleta seletiva é o melhor caminho para evitar doenças.

\section{DSC EII QI P3 (S2)}

Acontece por falta de interesse, pessoas folgadas!

A pessoa se cômoda ... relaxa porque não que mesmo ajudar, não quer colaborar. Tiro a conclusão de mim mesmo.

Não tenho tempo para separar, é muita coisa pra fazer, não dá pra mim né?

A coleta seletiva toma um pouquinho de tempo das pessoas.

Falta espaço, a gente não tem como ter as lixeiras separadas, o espaço é pequeno. A pessoa vai acumular muito lixo dentro de casa.

Se eu junto meu lixo e jogo na escada, por exemplo, to cooperando pra uma doença pra mim depois ou pros meus filhos, pros meus netos. O pessoal não sente assim, dar de si a utilidade humana pra ... ter saúde para as crianças e pra outras pessoas. Isso é terceiro mundo!

Não é culpa da pessoa que organizou, mas culpa da população. 
A prefeitura está fazendo a parte dela, já tem alguns postos de coleta de lixo, mas basta saber se os moradores também querem.

O pessoal da prefeitura pegam, mas os moradores da rua começam a jogar, jogar, eles se desanimam e acabam deixando.

\section{Idéia Central: Acontece por falta de estrutura e divulgação}

\section{DSC EII QI P3 (S3)}

Acontece porque falta administração Depende muito da prefeitura, da empresa encarregada.

Aqui em Vitória a coleta de lixo é muito bem feita, muito bem orientada, muito bem administrado. Eu não tenho nada a reclamar, sempre coletaram direitinho, sem problema nenhum. Aqui eis panha todo dia à noite.

\section{DSC EII QI P3 (S4)}

Talvez falta informação ou panfletagem. Não tem uma propaganda, não tem explicação correta pra população. Falta de orientação pra população mesmo!

A reeducação dos moradores é um dos motivos de dar certo em toda comunidade.

Um pouco é relaxamento da prefeitura mesmo né? Eles não dão as condições devidas.

Aqui, por exemplo, o local que ela tá instalada não é certo. Teria que ser um local assim de mais movimento, onde as pessoas passam e veêm que ali é o lugar de colocar o lixo.

\section{Pergunta 4:}

P4 - Teria mais alguma coisa a falar?

\section{Idéia Central: Não teria mais o que falar}

\section{DSC EI QI P4 (S1)}

Não. Só isso mesmo. 


\section{Idéia Central: Falta divulgação e estrutura para a Coleta Seletiva}

\section{DSC EI QI P4 (S2)}

Falta divulgação. Falta fazer propaganda melhor. Além da coleta seletiva poderia ser a separação do lixo como latas, garrafas, papéis. Aqui a prefeitura colocou essa separação, mas não teve muita divulgação.

O comércio está colocando nas caixinhas, mas está faltando propaganda, falar mais para as pessoas.

Poucos contêineres. Se houvesse em mais lugares talvez as pessoas se dispusessem a colocar mais. Se tivesse um aqui na esquina ficaria mais fácil, eu mesmo colocaria no carro para levar, é coisa para se programar.

Acho que seria uma boa para a comunidade, já tem condomínio que estão usando a coleta seletiva para fins lucrativos.

\section{Idéia Central: Falta educação e consciência para a coleta seletiva}

\section{DSC EI QI P4 ( S3)}

O povo ainda não tem educação, de estar respeitando o horário do lixo, de estar ensacolando, até mesmo amarrando o seu lixo para evitar doenças. É importante a Prefeitura estar fazendo junto com a comuniddade um trabalho de conscientização.

O pessoal da rua suja a rua, a prefeitura varre e varre, mas não adianta porque o povo não tem educação.

É feita a coleta seletiva e as próprias pessoas de rua abrem as comportas e derrubam esse lixo todo, onde dificulta a limpeza.

A partir da análise dos comentários verifica-se que a coleta seletiva é vista como algo benéfico, e que a insuficiência das ações de divulgação e mobilização mais uma vez é destacada.

Para os bairros sem coleta seletiva, onde se utilizou o questionário QII, tem-se: 


\section{Idéia Central: A coleta seletiva pode trazer benefícios}

\section{DSC EI QII P4 (S1)}

É uma coisa importante, essa coisa assim do meio ambiente, que poderia se colocado em prática.

Essa classificação eu acredito que nós temos muito que ganhar, uma qualidade de vida melhor.As próprias pessoas deviam se interessar mais um pouquinho para melhorar, porque começa deles mesmos.

A gente vê que a coleta de lixo normal já é tão dificultosa, então essa coisa do seletivo seria mais ainda. Então, deveria partir do principio de organizar essa coleta normal, para depois partir para um projeto maior.

A qualidade de vida depende de uma limpeza constante dos bairros e participação dos moradores colocando o lixo em seus lugares apropriados.

Posso falar sobre os ratos também, a gente tá aqui num tormento danado.

\section{DSC EI QII P4 (S2)}

A respeito do lixo é uma boa, que esse projeto venha a frente, dê certo.

Gostaria muito que isso acontecesse, que houvesse conscientização geral, que fosse feita essa coleta seletiva, esse benefício para todos nós.

Mas tem que ser mais divulgado, esclarecido, para que o povo viesse a conhecer e participar melhor.

O nosso povo brasileiro que está precisando de educação.

Acho que deveria ter um projeto para continuar porque isso é importante.

Isso é uma questão irreversível, a coleta seletiva tem que ser levado a sério. Com o caminhar das coisas, se faz necessário que cuidemos de nosso meio ambiente.

\section{Idéia Central: Falta estrutura para a coleta seletiva}

\section{DSC EI QII P4 (S3)}

A prefeitura de Vitória não tem esse trabalho. Tem aí algumas coisas com relação à coleta seletiva espalhada na nossa ilha. Alguns bairros tem, outros não.

A coleta seletiva, assim como o lixo também tem que ter um lugar específico público, não em frente da minha casa. 
Se há um órgão competente para isso, deveria tomar providências efetivas.

Quanto ao recolhimento de lixo, somos bem servidos, regularmente, não posso me queixar não.

\section{Idéia Central: Não teria mais o que falar}

\section{DSC EI QII P4 (S4)}

Não, não tenho mais nada a para comentar. Mais ou menos por esse lado aí. No momento só isso mesmo.

\section{Idéia Central: A coleta seletiva traz benefícios}

\section{DSC EII QI P4 (S1)}

Nessa parte da coleta de lixo, Vitória está de parabéns. Tem aquela Usina de Reciclagem que todas grandes cidades deveria ter.

Aqui, aproveita-se muita coisa. Seria exemplo para outras demais prefeituras.

Acho que esse tipo de trabalho deveria se estender em outros Bairros da Grande Vitória. É uma forma de conscientizar aos moradores e a população em geral para os riscos da doença.

\section{DSC EII QI P4 (S2)}

A respeito da coleta, tenho que agradecer a comunidade e todos pela participação.

O projeto é bom é a qualidade de vida de nós moradores.

Acho importante, tem que ser mantida sempre que possivel.

Acho muito legal o trabalho.

Jamais jogo um papel no chão, jogo qualquer coisa na rua, eu participo.

\section{DSC EII QI P4 (S3)}

Importante a coleta seletiva, muita gente até sobrevive desse lixo né!

Uma lâmpada quebrada, um vidro quebrado, a gente não botar no lixo junto com as outras coisas que pode ocasionar um acidente para quem tá trabalhando.

A gente pode ajudar as outras pessoas a sobreviver fazendo reciclagem no lixo. 
Basta a conscientização da população em fazer a coleta seletiva e ter mais programas de incentivo a coleta seletiva.

Continuar fazendo a coleta que os outros faz a recicragem por aí.

\section{Idéia Central: Falta educação e consciência para a coleta seletiva}

\section{DSC EII QI P4 (S4)}

As pessoas que não cuida, que não zelar. A limpeza depende de mim.

O povo acha que serviço ... teria que ser feito pela prefeitura e todos os dias a coleta total do lixo para que a cidade ficasse limpa.

Tem bairro que a gente vê desmazelado.É por causa da população. As pessoas que jogam lixo de qualquer maneira, em qualquer lugar.

É o horário, né? Em muitos lugares eles passam da hora de coleta de lixo. Cada um tem a sua parte, todo mundo tem a sua participação. Eles avisaram o no radio e na televisão que não pode colocar fora do horário e eles colocam. Sabe por causa de quê ? Eles querem tirar de dentro de casa e colocar na rua.

Os coletor vem todos os dias, tem muita gente que joga saco de lixo pelas escadas.

É por isso que as pessoas não vivem bem. Você fala fulano não age assim aí ele fala você é otário. Falta de educação mesmo, depende da gente.

\section{DSC EII QI P4 (S5)}

Não, Só isso só. Podia até falar mas só isso só mesmo. 
Anexo 05.

Pesquisa Quantitativa (Fase 4)

Participação Social na Coleta Seletiva 


\section{Participação Social - Instrumento de pesquisa aplicado}

\section{Enquête - site da prefeitura de Vitória}

\section{ENQUETE - Pesquisa sobre Coleta Seletiva de Lixo}

O lixo é um grande problema em todas as cidades. Preocupada com essa questão, a Prefeitura de Vitória está elaborando um programa para melhorar o sistema de coleta do lixo domiciliar. Para isso, pedimos a sua ajuda. Se você mora e/ou trabalha na cidade, responda ao questionário abaixo. Obrigado.

Questionário:

1. Grau de instrução

$1^{\circ}$ grau

$2^{\circ}$ grau

superior

\section{Renda familiar}

até $\mathrm{R} \$ 500,00$

de $\mathrm{R} \$ 501,00$ a $\mathrm{R} \$ 1.000,00$

de $R \$ 1.001,00$ a $R \$ 1.500,00$

de $R \$ 1.501,00$ a $R \$ 2.000,00$

mais de $\mathrm{R} \$ 2.001,00$

3. Você sabe o que é coleta seletiva de lixo?
Sim
Não

\section{ATENÇÃO:}

Caso a sua resposta à pergunta 3 seja sim, prossiga, respondendo ao questionário.

Caso a sua resposta seja não, vá direto para a pergunta 5 .

4. Onde você obteve informações sobre a coleta seletiva de lixo (pode marcar mais de uma opção):

escola

TV

jornais e revistas

internet

campanhas de divulgação

outros

5. Você estaria disposto a participar da coleta seletiva, separando o lixo seco do lixo úmido na sua residência e/ou local de trabalho?

$$
\text { sim não não sei }
$$

6. O que o motivaria a participar da coleta seletiva?

melhoria na qualidade de vida e limpeza

preservação do meio ambiente

consciência e educação

geração de empregos

campanhas de divulgação

outros

9. Que informações você gostaria de ter sobre a coleta seletiva de lixo? 
Anexo 06.

Pesquisa Quantitativa (Fase 5)

Participação Social na Coleta Seletiva 


\section{Participação Social - Instrumento de pesquisa aplicado}

\section{Questionário - pessoal da prefeitura e empresas contratadas}

Pesquisa sobre Coleta Seletiva de Lixo - PMV

Prezado(a) Sr.(a),

Estamos desenvolvendo atualmente junto a Faculdade de Saúde Pública da Universidade de São Paulo pesquisa sobre programas de coleta seletiva no Brasil, onde o município de Vitória é o nosso referencial de estudo.

Neste sentido solicitamos seu apoio no sentido de responder o questionário a seguir, com o máximo de sinceridade e sem preocupação com formalidades de ordem técnica, e nos retornar o mais breve possível.

1. Grau de instrução

\section{Questionário}
( ) $1^{\circ}$ grau
( ) $2^{\circ}$ grau
( ) superior
( ) Outro. Especificar
2. Renda familiar
( ) até $\mathrm{R} \$ 500,00$
( ) de $\mathrm{R} \$ 501,00$ a $\mathrm{R} \$ 1.000,00$
( ) de R\$ $1.001,00$ a $\mathrm{R} \$ 1.500,00$
( ) de $\mathrm{R} \$ 1.501,00$ a $\mathrm{R} \$ 2.000,00$
( ) mais de $\mathrm{R} \$ 2.001,00$

3. Em sua residência existe a separação do lixo para a coleta seletiva de lixo?

( ) $\operatorname{Sim}$

( ) Não

\section{ATENÇÃO:}

Caso a sua resposta à pergunta 3 seja sim, prossiga, respondendo ao questionário.

Caso a sua resposta seja não, vá direto para a pergunta 5 .

4. Há quanto tempo você participa da Coleta Seletiva?

( ) Há menos de seis meses

( ) de seis meses a um ano

( ) entre um e dois anos

( ) Há vários anos

( ) Outro. Especificar

5. Onde você obteve informações sobre a coleta seletiva de lixo (pode marcar mais de uma opção):

( ) escola

( ) $\mathrm{TV}$

( ) jornais e revistas

( ) internet

( ) campanhas de divulgação

( ) Outros. Especificar 
6. O que o motiva(ria) a participar da coleta seletiva?

( ) melhoria na qualidade de vida e limpeza

( ) preservação do meio ambiente

( ) consciência e educação

( ) geração de empregos

( ) campanhas de divulgação

( ) Outros. Especificar

7. Como você avalia o Programa de Coleta Seletiva de Vitória, antes da ampliação ocorrida na Segunda quinzena de setembro/ 2000 ?

( ) ótimo

( ) Bom

( ) Regular

( ) Ruim

( ) Péssimo

( ) Outro. Especificar

8. Por quanto tempo você poderia armazenar o lixo reciclável em sua casa ou local de trabalho?

( ) 01 a 02 dias

( ) 01 semana

( ) 02 semanas

( ) 01 mês

( ) Outros. Especificar:

9. Qual o grau de dificuldade para a separação do lixo reciclável para a Coleta Seletiva ?

( ) muito difícil

( ) difícil

( ) médio

( ) fácill

( ) muito fácil

10. As informações que recebe sobre a Coleta Seletiva são suficientes?

( ) $\operatorname{sim}$

( ) não

8. Em poucas palavras como avalia o novo modelo de ECOPOSTO instalado na cidade em relação ao anterior?

Como trata-se de um trabalho científico necessitamos de sua assinatura no Termo de Consentimento em anexo para assegurar a veracidade dos dados. Esclarecemos, entretanto, que na tabulação e apresentação dos resultados não haverá citação de nomes.

Obrigado pela colaboração! 
Anexo 07.

Material de Divulgação das

Experiências de Coleta Seletiva Visitadas 


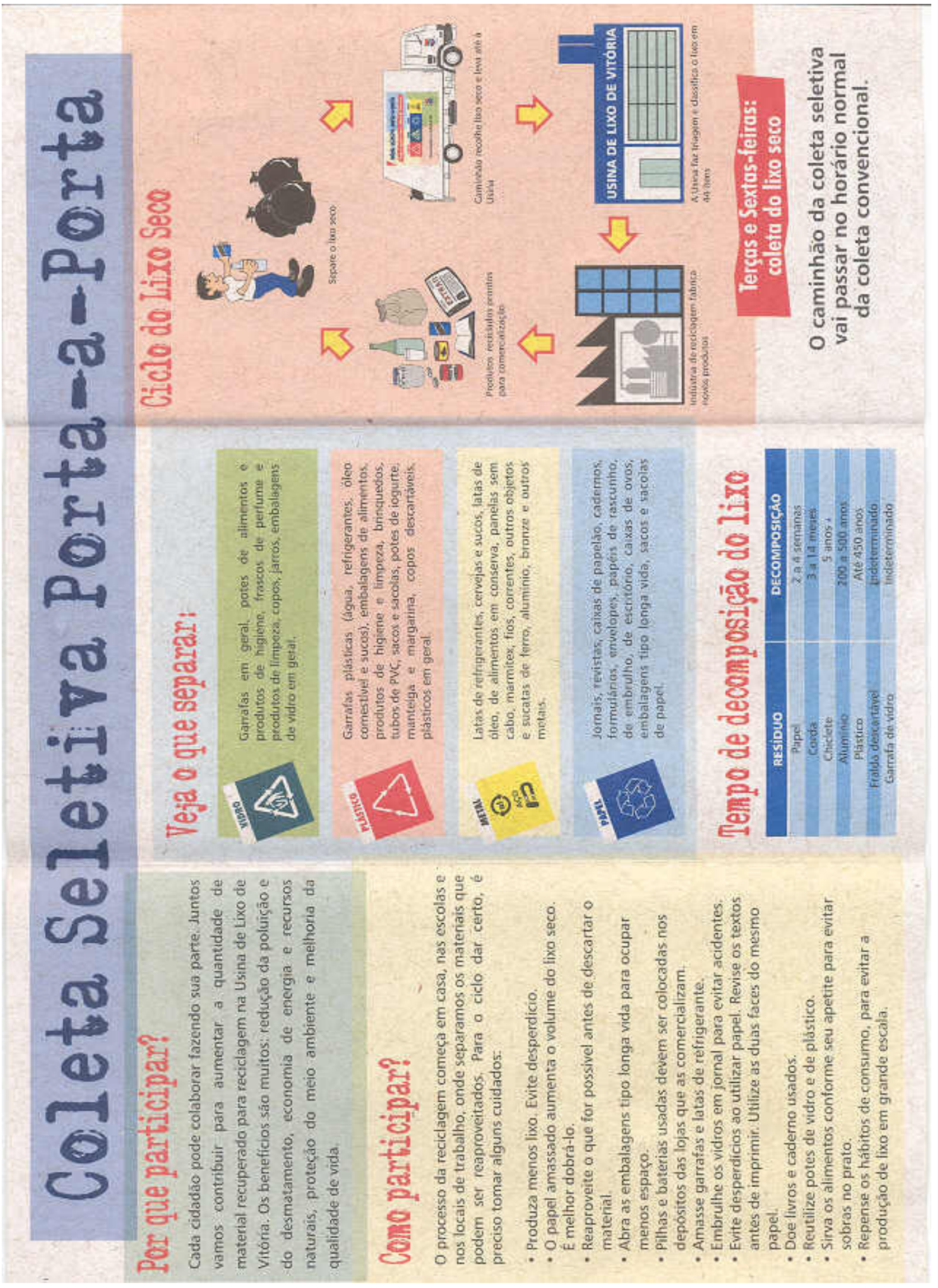




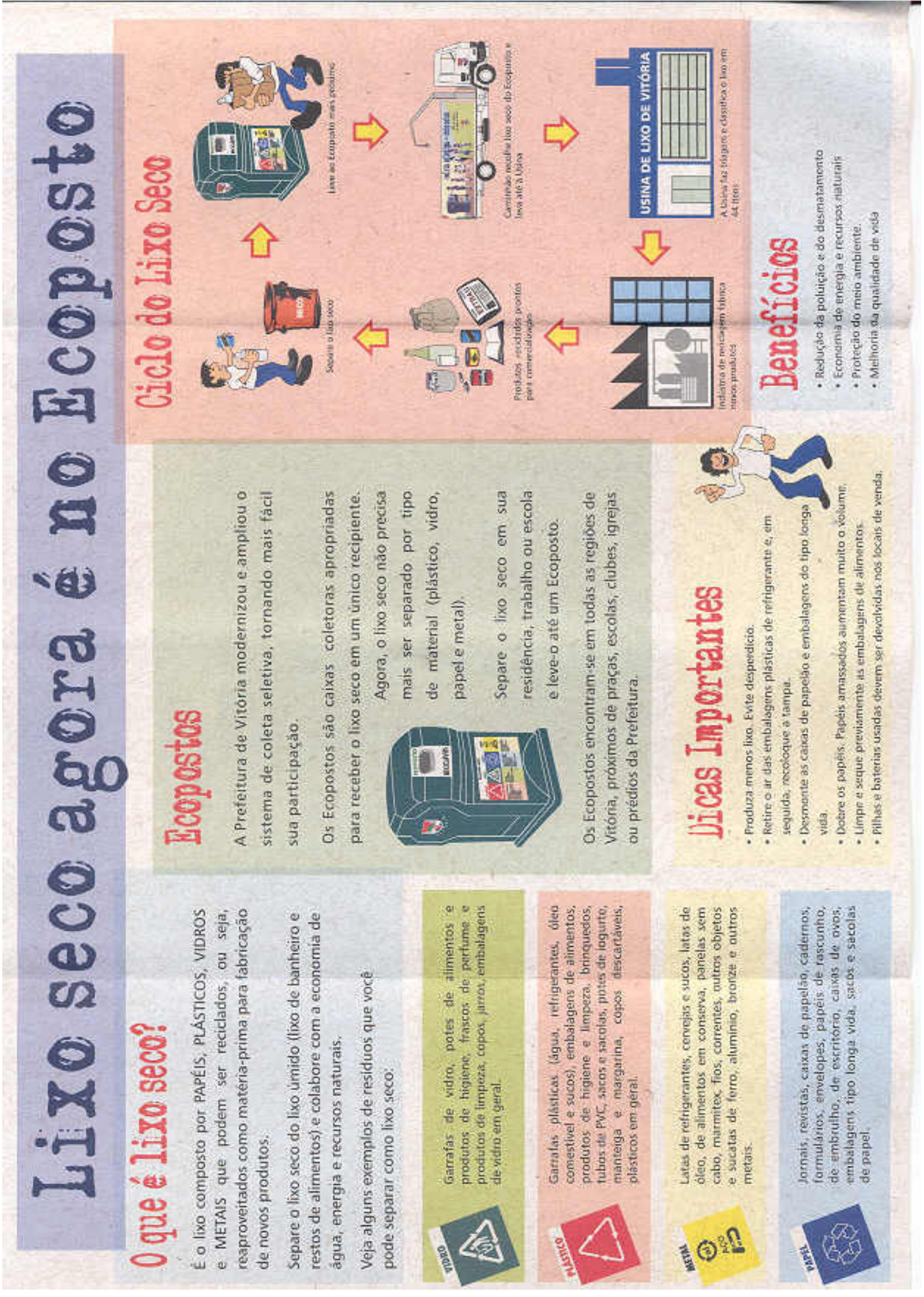



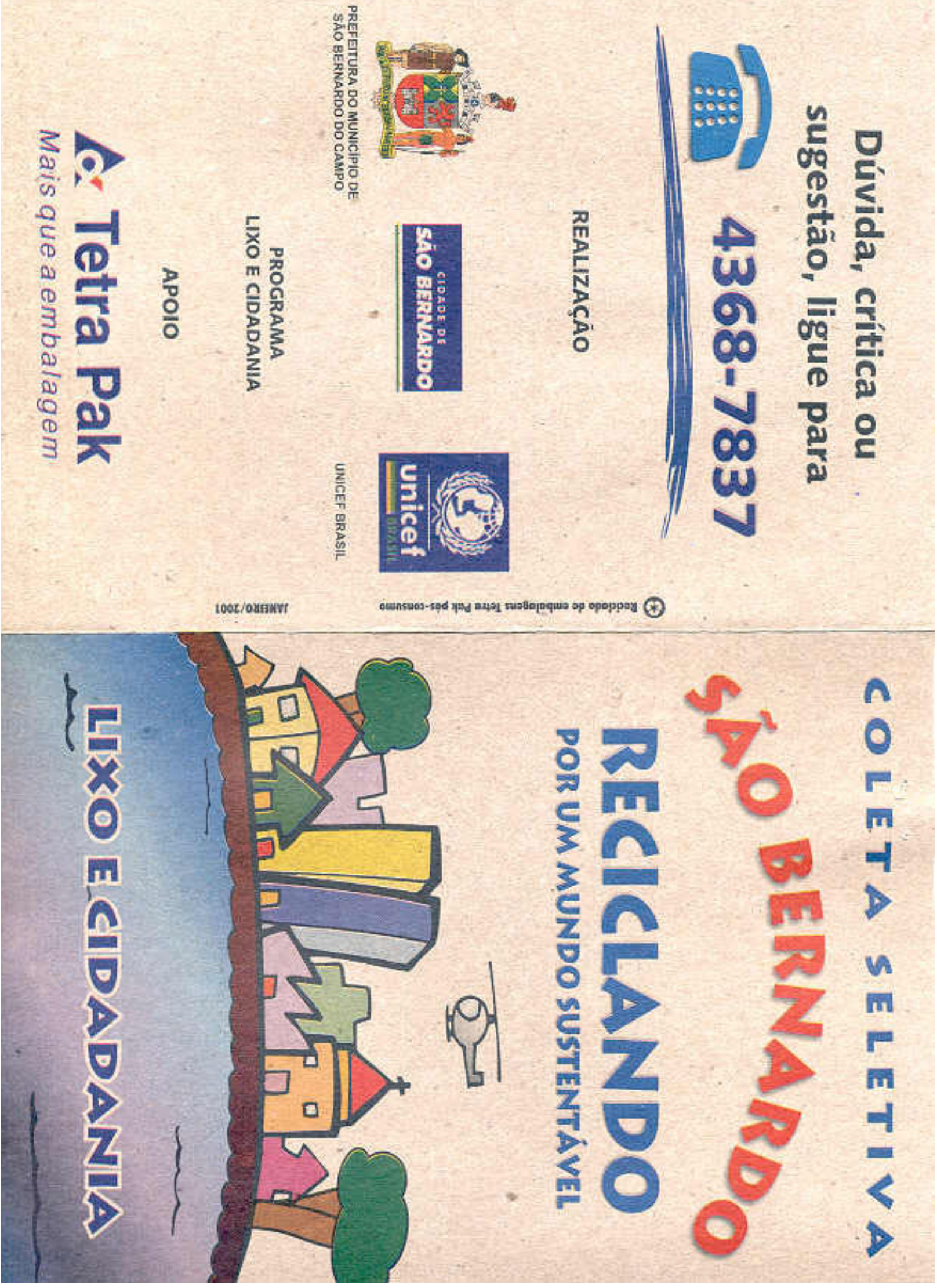

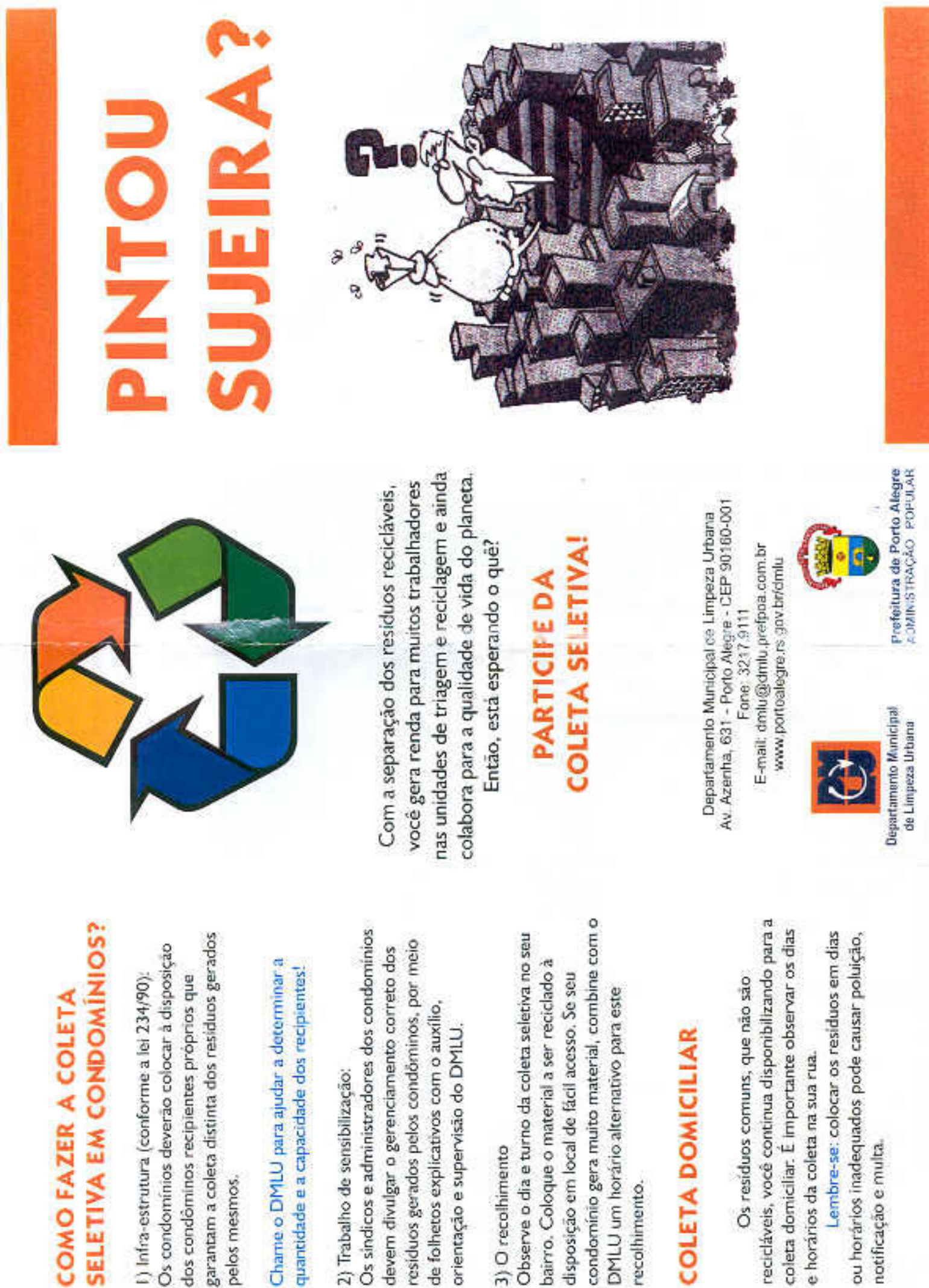


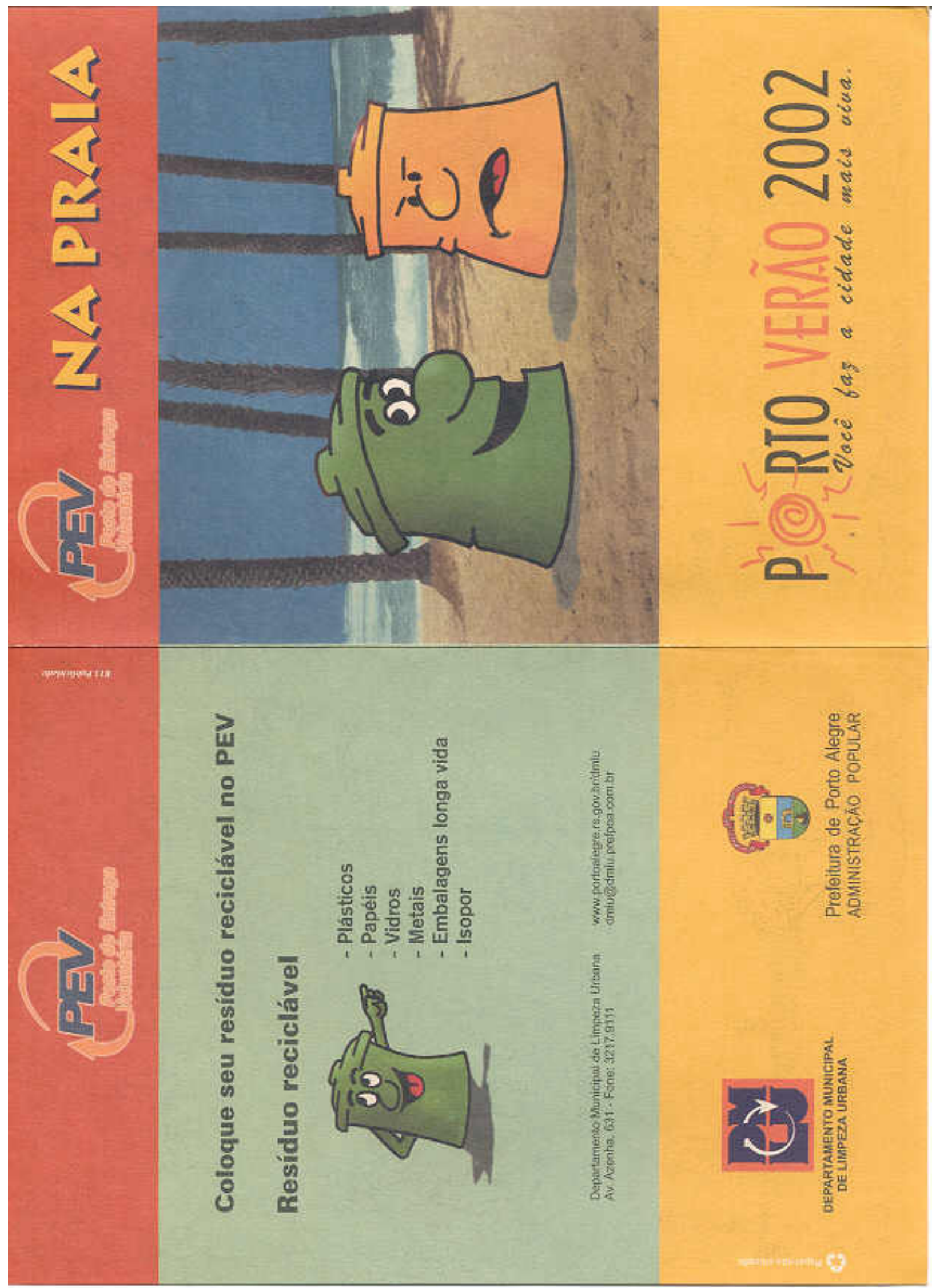




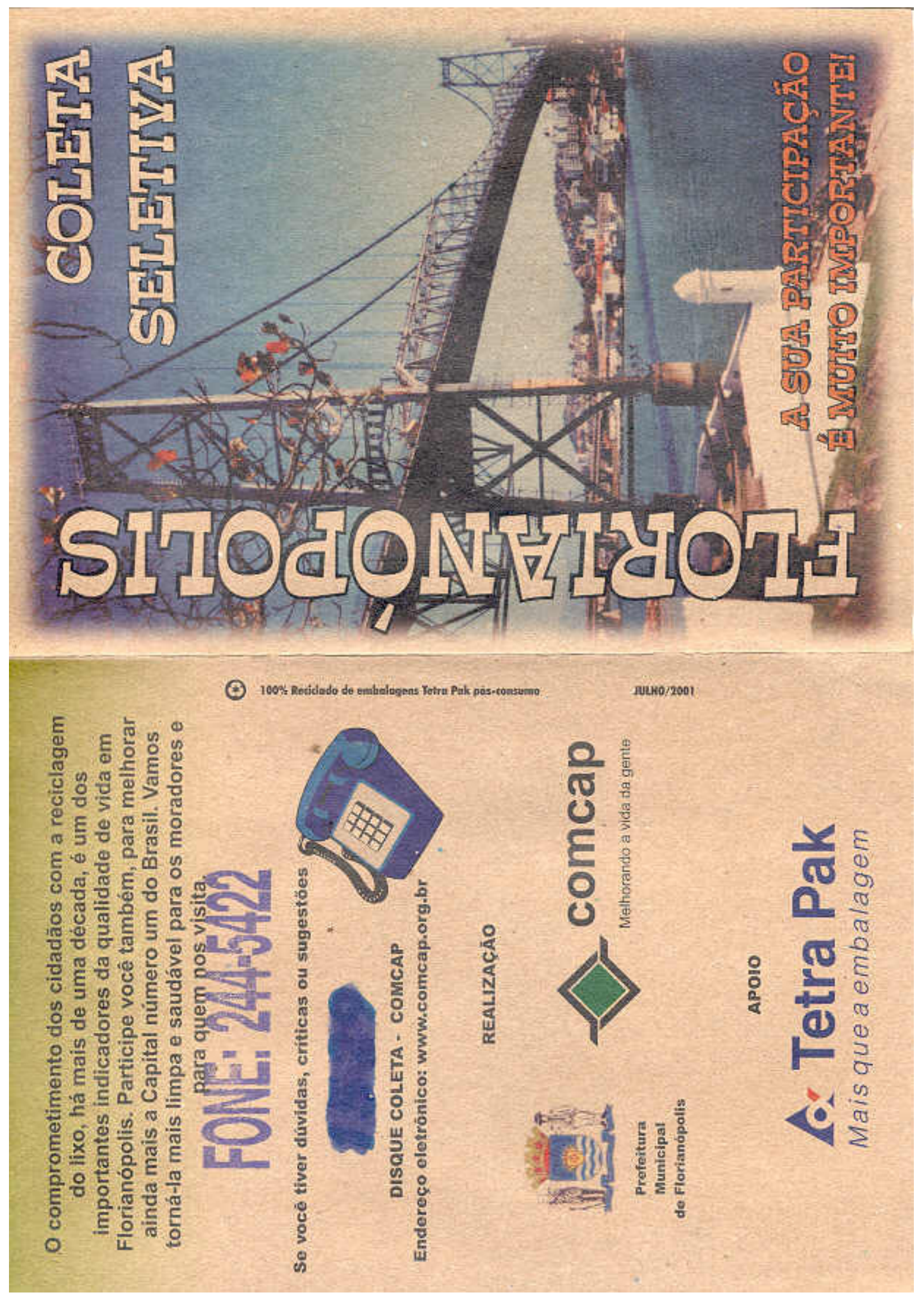



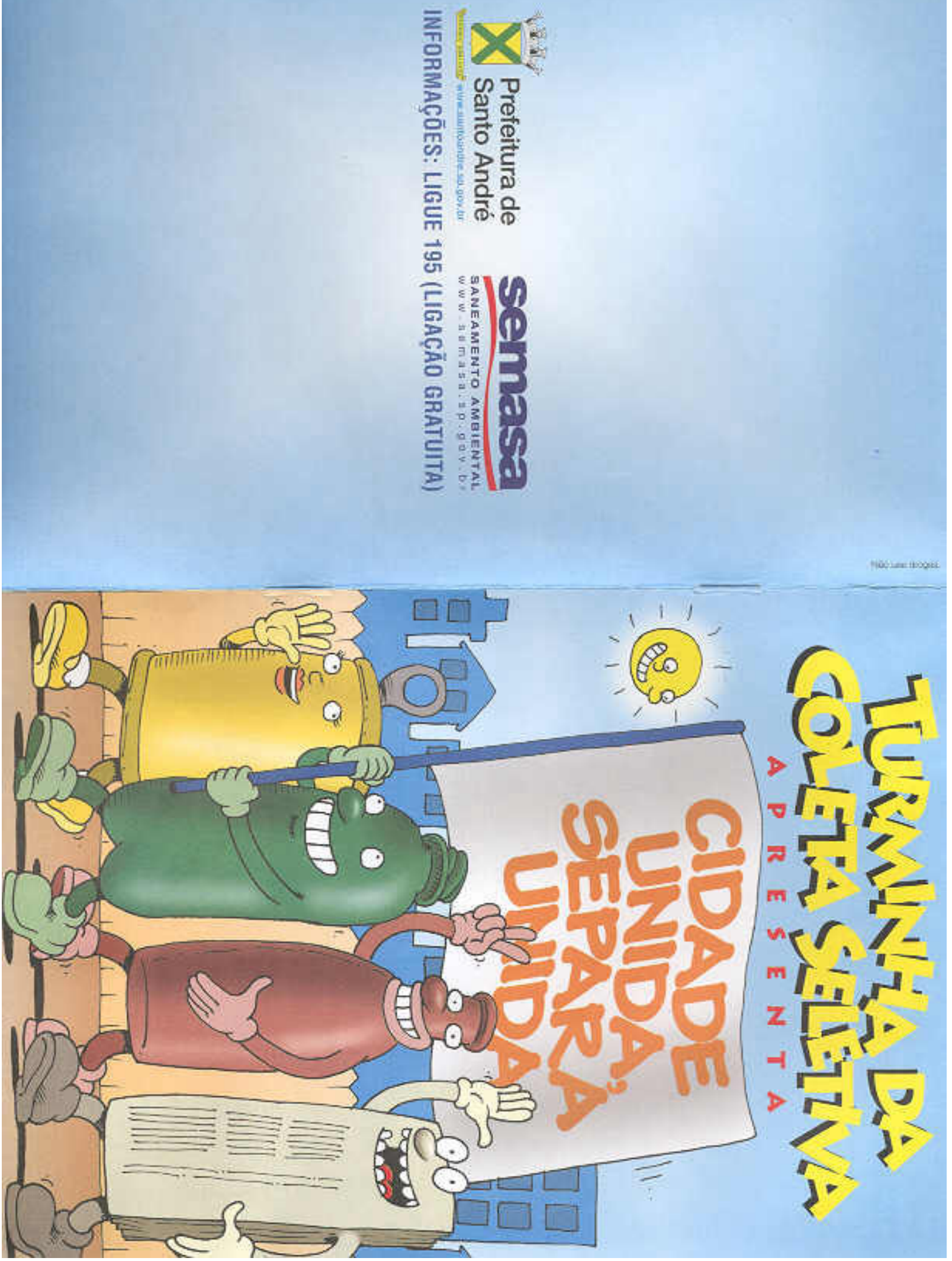